\title{
Geology and Mineral Resources of the
}

\section{Lemhi Pass Thorium District,}

Idaho and Montana

GEOLOGICAL SURVEY'PROFESSIONAL PAPER 1049-A
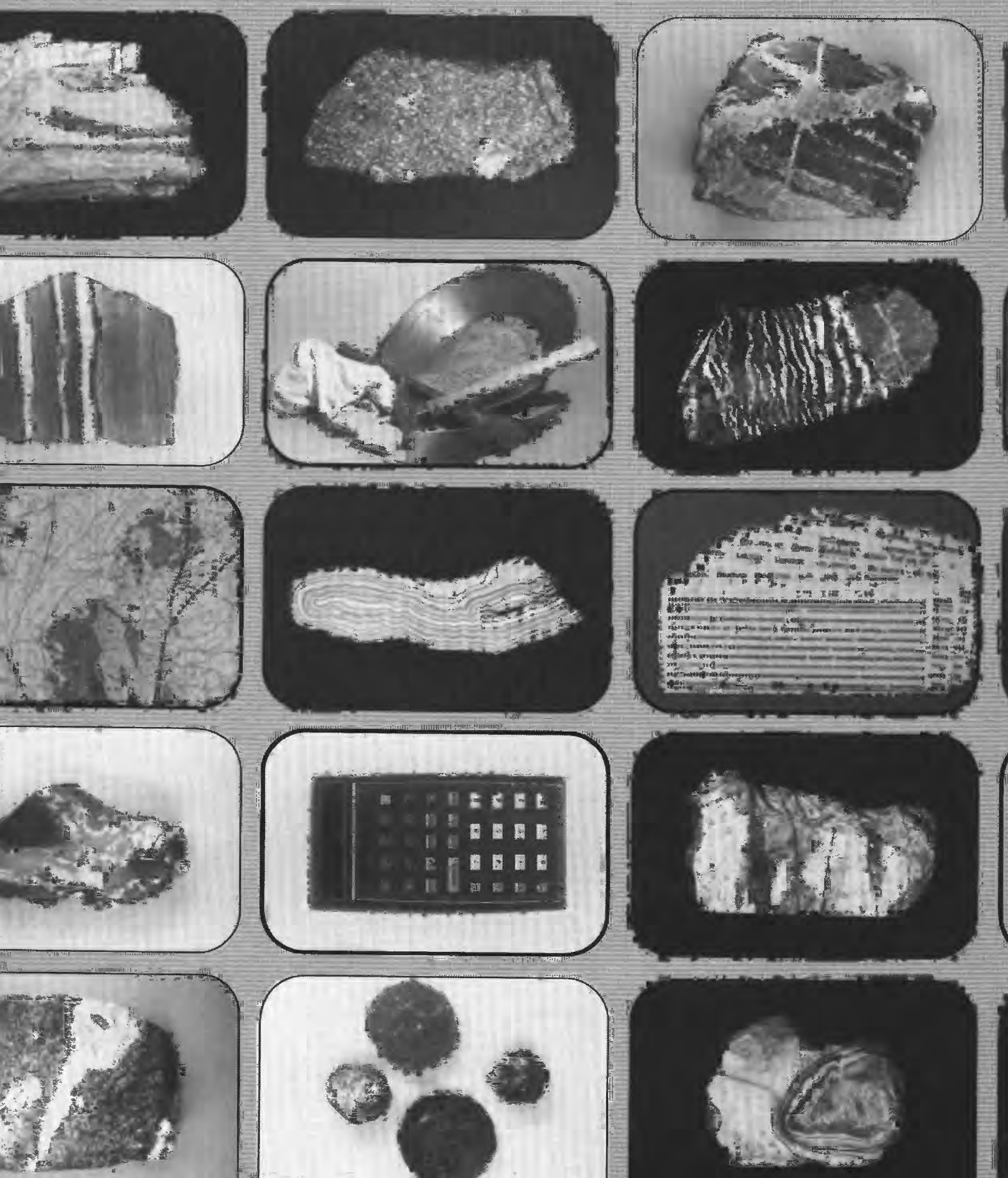
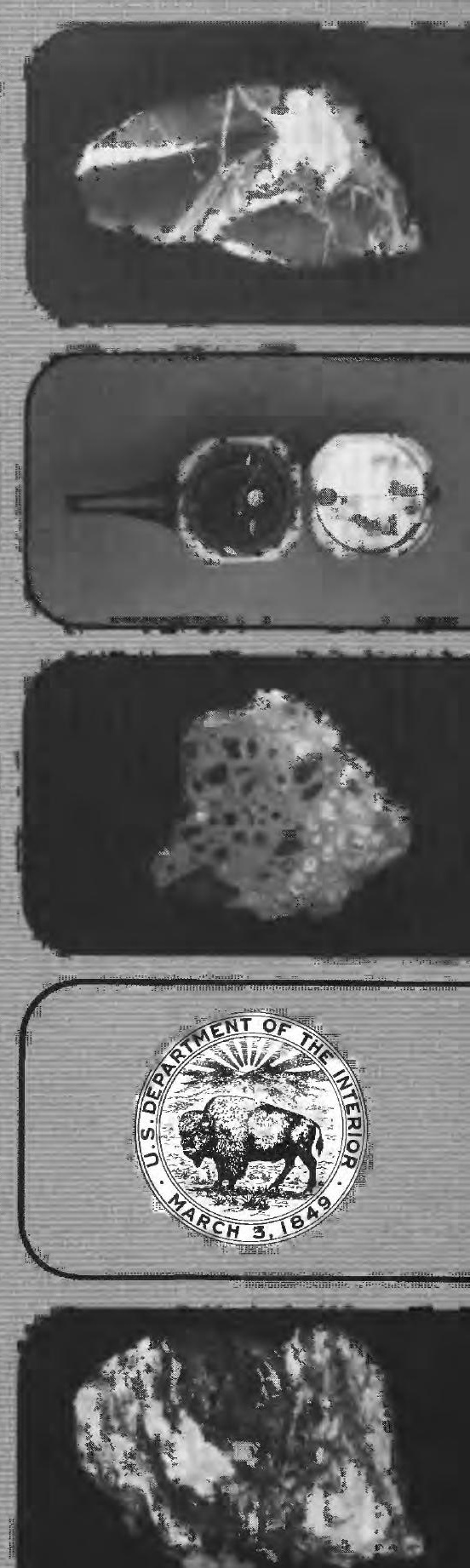
COVER PHOTOGRAPHS

\begin{tabular}{|c|c|c|c|c|c|}
\hline 1 & 2 & 3 & 4 & \multirow{5}{*}{$\begin{array}{l}\text { 1. Asbestos ore } \\
\text { 2. Lead ore, Balmat mine, N. Y. } \\
\text { 3. Chromite, chromium ore, Washington } \\
\text { 4. Zinc ore, Friedensville, Pa. } \\
\text { 5. Banded iron-formation, Palmer, } \\
\text { Mich. } \\
\text { 6. Ribbon asbestos ore, Quebec, Canada } \\
\text { 7. Manganese ore, banded } \\
\text { rhodochrosite }\end{array}$} & \multirow{2}{*}{$\begin{array}{l}\text { 8. Aluminum ore, bauxite, Georgia } \\
\text { 9. Native copper ore, Keweenawan } \\
\text { Peninsula, Mich. } \\
\text { 10. Porphyry molybdenum ore, Colorado }\end{array}$} \\
\hline 5 & & 6 & & & \\
\hline & 7 & & 8 & & 11. Zinc ore, Edwards, N.Y. \\
\hline 9 & & 10 & & & $\begin{array}{l}\text { 12. Manganese nodules, ocean floor } \\
\text { 13. Botryoidal fluorite ore, }\end{array}$ \\
\hline 11 & 12 & 13 & 14 & & $\begin{array}{l}\text { Poncha Springs, Colo. } \\
\text { 14. Tungsten ore, North Carolina }\end{array}$ \\
\hline
\end{tabular}




\section{Geology and Mineral Resources of the Lemhi Pass Thorium District, Idaho and Montana}

By MORTIMER H. STAATZ

With a section on DESGRIPTION OF SELECTED THORIUM VEINS

By MORTIMER H. STAATZ, U.S. GEOLOGICAL SURVEY,

and BYRON J. SHARP and DONALD L. HETLAND,

U.S. ENERGY RESEARCH AND DEVELOPMENT ADMINISTRATION

GEOLOGY AND RESOURCES OF THORIUM IN THE UNITED STATES \begin{tabular}{lllll}
\hline GEOLOGICAL SURVEY PROFESSIONAL PAPER & 1049 -A
\end{tabular}

A description of the distribution, geologic setting, mineralogy, and chemistry of the thorium

veins in the Lemhi Pass district

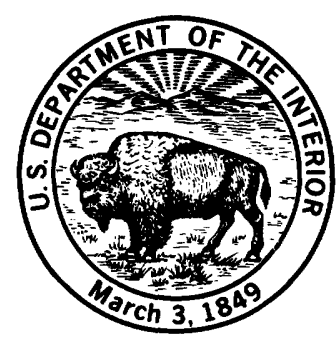

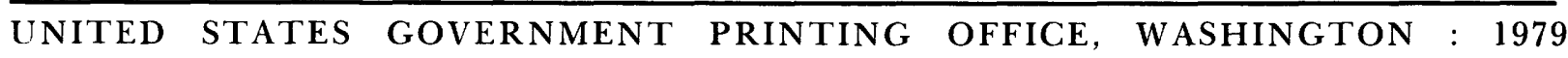




\title{
UNITED STATES DEPARTMENT OF THE INTERIOR
}

\author{
CECIL D. ANDRUS, Secretary
}

\section{GEOLOGICAL SURVEY}

H. William Menard, Director

Library of Congress Cataloging in Publication Data

Staatz, Mortimer Hay, 1918-

Geology and mineral resources of the Lemhi Pass thorium district, Idaho and Montana.

(Geology and resources of thorium in the United States)

(Geological Survey Professional Paper 1049-A)

Bibliography: p. 83

Includes index.

Supt. of Docs. no.: I 19.16:1049-A

1. Geology-Lemhi Pass region, Idaho and Montana. 2. Thorium ores-Lemhi Pass region, Idaho and Mont.

I. Title. II. Series. III. Series: United States Geological Survey Professional Paper 1049-A.

$\begin{array}{lll}\text { QE1 04.L4S7 } & 557.96^{\prime} 78 & 77-608173\end{array}$

For sale by the Superintendent of Documents, U.S. Government Printing Office

Washington, D.C. 20402

Stock Number 024-001-03208-2 


\section{ILLUSTRATIONS}

Plate 1. Geologic map and sections of the Lemhi Pass thorium district, Lemhi County, Idaho, and Beaverhead County, Montana

2. Geologic maps of thorium properties, Lemhi Pass thorium district, Idaho and Montana.

1. Index map of the Lemhi Pass thorium district

2. Photograph of down-faulted block of Challis Volcanics surrounded by Precambrian Y quartzite

3. Photographs of Precambrian Y rocks

4. Diagrammatic cross section of the Challis Volcanics

5. Photographs of quartzite-bearing rhyolite tuff

6. Photograph of conglomerate of Flume Creek

7. Photographs of basalt-rhyodacite sequence

8. Ternary diagram showing relation of $\mathrm{CaO}, \mathrm{Na}_{2} \mathrm{O}$, and $\mathrm{K}_{2} \mathrm{O}$ in rocks from the Challis Volcanics

9. Graph showing relation of $\mathrm{MgO}$ to total iron oxide in rocks from the Challis Volcanics

10. Photograph of thin-bedded tuffaceous sedimentary rocks

11. Photograph of large landslide filling headwaters of Little Eightmile Creek basin

In pocket In pocket

2-14. Photographs:

12. Thrusts

13. Steep faults

14. Thorium veins

15. Attitudes of thorium veins in the Lemhi Pass district

16. Photomicrographs of brecciated and granulated vein material under crossed nicols

17. Photomicrographs of thorium vein material

18-34. Geologic maps of mining properties:

18. West end of Lucky Horseshoe vein

19. Buffalo property

20. Black Bull No. 3 property

21. Deer Fraction IA veins

22. Black Bear No. 2 property

23. Beaverhead, Mont., vein

24. Wonder No. 18 property

25. Little Dandy vein

26. Dan Patch property

27. Elkhorn property

28. Apex vein

29. Lone Star No. 2 property

30. Silver Queen 38A property

31. Nellie B property

32. Photograph of northwest-trending vein on Black Rock, Mont., property

33. Geologic map of Black Rock, Idaho, property

34. Geologic map of $\mathrm{ThO}_{2}$ property

\section{A3}

6

9

14

15

16

17

19

2I

24 


\section{TABLES}

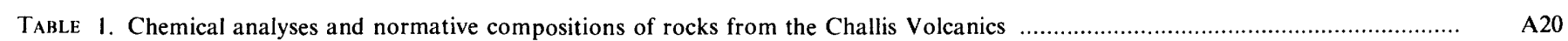

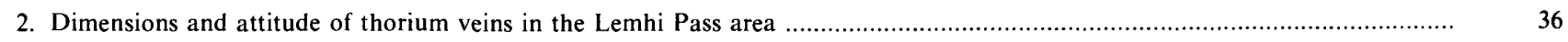

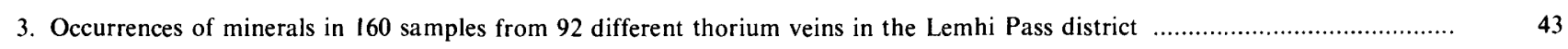

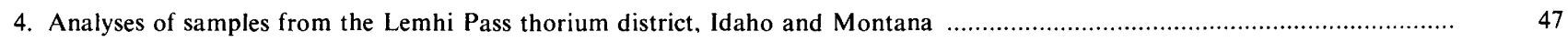

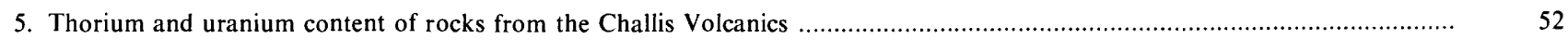

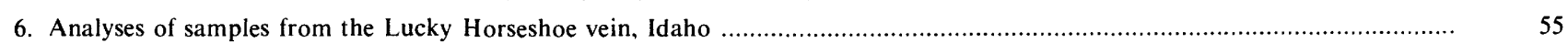

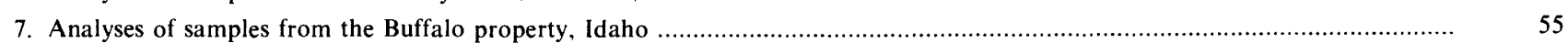

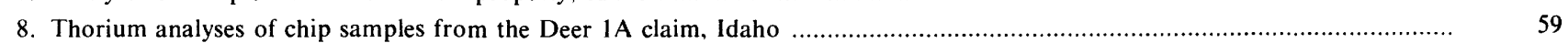

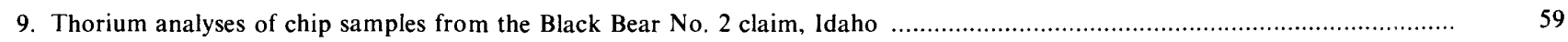

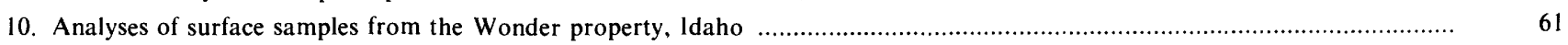

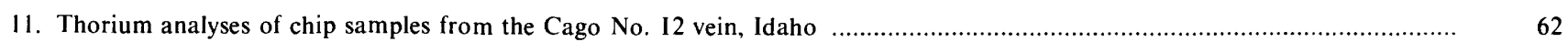

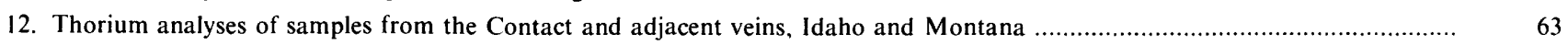

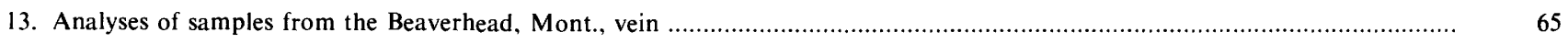

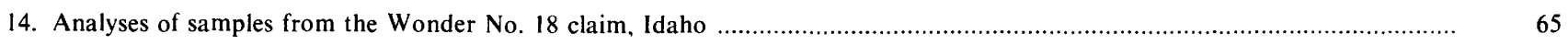

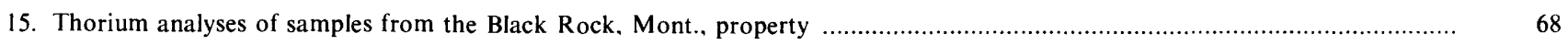

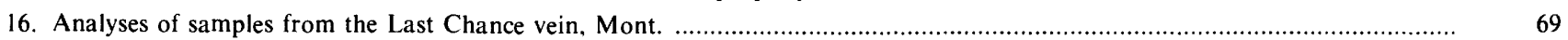

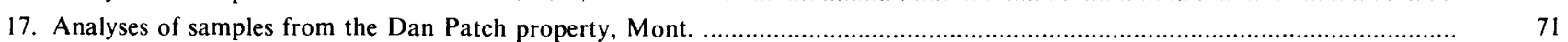

18. Analyses of chip samples from the Reactor property, Mont.

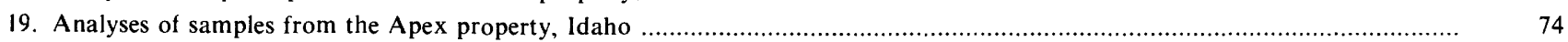

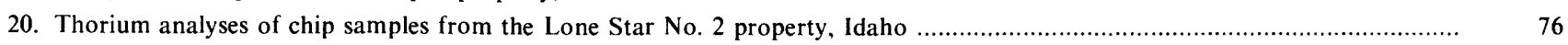

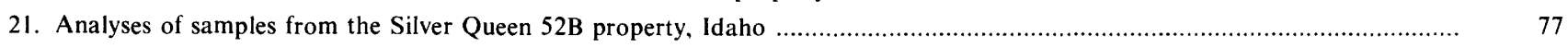

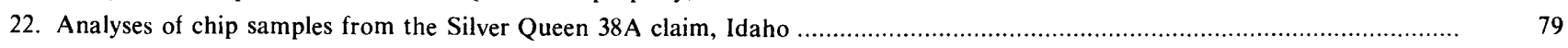

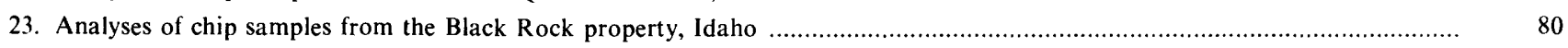

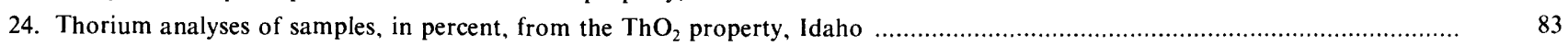





\title{
GEOLOGY AND MINERAL RESOURCES OF THE LEMHI PASS THORIUM DISTRICT, IDAHO AND MONTANA
}

\author{
By Mortimer H. StaAtz
}

\begin{abstract}
The Lemhi Pass thorium district covers approximately 55 square miles in the central part of the Beaverhead Mountains. Approximately 250 veins were mapped in this rectangular district that lies astride the Continental Divide in Idaho and Montana. Thorium veins make up 87 percent of this total. Copper and barren quartz veins each make up 6 percent and iron veins less than 1 percent. Thorium veins range in length from a few feet to at least 4,350 feet and in thickness from thin seams to 40 feet. Fifteen veins are more than 1,000 feet in length. The longest vein, the Last Chance, is also the thickest and ranges from 5 to 40 feet. Much of it is $10-25$ feet thick. The veins persist at depth, and the central vein on the Iola property has been traced on the surface for a vertical distance of 560 feet. The veins may strike in almost any direction, but the strikes of more than half of them fall within either the N. $40^{\circ}-60^{\circ} \mathrm{W}$. or $\mathrm{N} .70^{\circ}-80^{\circ} \mathrm{W}$. range. Most of them have a steep dip. The thorium veins are generally found along small fractures and shears that are related to faulting of Tertiary age. Movement along these fractures commonly occurred before, during, and after the vein was emplaced. Although $\mathbf{4 5}$ minerals have been identified in various thorium veins, only a few are relatively common. Quartz and microcline are the principal gangue minerals. Hematite and limonite (chiefly goethite) commonly vein the earlier minerals and color the veins. Thorite is the most abundant thorium mineral, although monazite is present in many veins. Other thorium or rare-earth minerals found in a few veins are brockite, allanite, xenotime, synchisite, bastnaesite, and doverite. Not all the thorium occurs in discrete thorium minerals; some of it is in limonite. The $\mathrm{ThO}_{2}$ content of 420 samples from this district ranges from 0.0008 to 9.4 percent. Many of the larger veins have an average $\mathrm{ThO}_{2}$ content of more than 0.4 percent. The overall total rare-earth oxide content of these veins is about equal to the thoria content, although in various veins the ratio between the two may vary widely. Neodymium is the most abundant rare earth in many of the veins. In addition, europium makes up a greater proportion of the total rare earths in about 70 percent of the Lemhi Pass veins than it does in other reported occurrences. The indicated thorium resources in this district are 176,500 short tons of $\mathrm{ThO}_{2}$; the inferred resources are 128,900 short tons of $\mathrm{ThO}_{2}$. The ten largest veins in the district having an average grade of 0.43 percent $\mathrm{ThO}_{2}$ contain 96 percent of these resources. Rare-earth anatyses are available for only 25 veins in the district. These veins contain indicated resources of 186,000 short tons rare-earth oxides and inferred resources of 122,000 short tons total rare-earth oxides. The ratio of total rare-earth oxides to thoria in these 25 veins is four to three. The thorium content of all
\end{abstract}

the veins greatly exceeds the uranium content, and the latter is of little economic significance in this area.

The only other veins of economic importance in the Lemhi Pass thorium district are copper veins. Small amounts of copper ore have been produced from the Copper Queen, Bluebird, and Last Chance properties.

The veins in this district are middle Tertiary or younger in age and were formed after both the Challis Volcanics and the diorite were emplaced. The copper veins are somewhat older than the thorium ones. The latter are believed to have formed from fluids derived from magma that formed buried alkalic rocks. These fluids followed major through-going fractures(faults) but deposited their load along smaller subsidiary breaks. The temperature of formation is probably low, as suggested by the fine grain size of the veins and the distance that some of the fluids apparently traveled.

Precambrian $Y$ sedimentary rocks, which are the host rocks for the thorium veins, are the oldest rocks in the Lemhi Pass district and directly underlie the greater part of the area. The older part of these Precambrian rocks lies below the Peterson Creek thrust fault. This part of the section has been divided by lithology into quartzite and siltite units. Above the thrust fault and in the Ramsey Mountain area the Precambrian $Y$ rocks are divided from oldest to youngest into the Big Creek, Apple Creek, Gunsight, and Swauger Formations.

South of the Peterson Creek thrust fault, the Madison Limestone of Mississippian age is thrust over the Big Creek Formation. Challis Volcanics of Tertiary age once covered the entire area but have been largely removed by erosion. The Challis is now preserved in downfaulted blocks and small erosional remnants. The rocks of the Challis can be divided into two, and possibly three divisions. Rocks of the first division, which contains more than 90 percent of the Challis, consist of a thick basalt-rhyodacite sequence and associated tuffs and conglomerates. Rocks of this division have been divided into the following seven units in ascending order: (1) Basal conglomerate, (2) quartzite-bearing rhyolite tuff, (3) conglomerate of Flume Creek, (4) tuff of Lemhi Pass, (5) basalt-rhyodacite sequence, (6) tuff of Curtis Ranch, and (7) a flow-breccia unit. Rocks of a second division, which are separated from those of the first by an angular unconformity, consist of a younger basalt and a sanidine-quartz welded tuff. Rocks of a third division are light-colored quartz latite flows or intrusives in the northeast part of the district. These are poorly exposed, but the general relations of this rock type to the rest of the Challis Volcanics suggests that it is younger than the bulk of the Challis.

In Tertiary time, after the Challis Volcanics were deposited and uplifted, a sequence of lacustrine tuffaceous sedimentary rocks were formed in the 
large basin occupied by the Lemhi River and in a smaller basin in which Cow and Yearian Creeks now flow. They consist mainly of fine-grained tuffaceous sedimentary rocks with layers or lenses of conglomerate.

Diorite dikes are scattered through the Precambrian Y rocks; these dikes were emplaced in Tertiary time after the Challis Volcanics.

Unconsolidated deposits of Quaternary age are widespread and mask the underlying rocks in about a fifth of the area. Here they have been divided into the following eight units: (1) Older glacial deposits, (2) younger glacial deposits, (3) terrace deposits, (4) alluvial fans, (5) rock glacier, (6) landslide deposits, (7) mud flow, and (8) alluvium.

Faulting is the major structural element, and both thrust faults and steeply dipping faults occur in the Lemhi Pass district. The large Peterson Creek thrust fault in the southeast part of the district separates the area into two geologically distinct areas. Above this thrust, thrusting is the predominant type of faulting; below it, steep faults dominate. The greater number of steep faults strike either northwest or northeast. Although offsets indicate that the faults are of several relative ages, most of them were formed during a period of Tertiary tectonism in which the Challis Volcanics were emplaced. Eight small folds, probably produced by local stresses, are found in this district.

\section{INTRODUCTION}

The Lemhi Pass thorium district has the largest known resources of thorium in veins in the United States. The area (fig. 1), which is approximately 13.5 miles north-south by 12 miles east-west, is part of a north-northwest-trending thorium-rich belt at least 85 miles long. This belt extends from southern Ravalli County, Mont. to Bull Canyon, 10 miles southeast of Leadore, Idaho. Rocks or veins that are enriched in thorium but that are not necessarily a high-grade source include carbonatites in the Sheep Creek area of southern Ravalli County and the Mineral Hill area of northern Lemhi County, a granite intrusive near Bull Canyon, and veins in the Lemhi Pass district, the Diamond Creek area 8 miles northwest of Salmon, and along the Salmon River west of North Fork. Although veins occur in three areas, most of them occur in the Lemhi Pass area. Sharp and Hetland's map $(1968$, pl. 1) shows only six veins in the Diamond Creek area and one along the Salmon River.

\section{LOCATION AND ACCESSIBILITY}

The Lemhi Pass thorium district is astride the Beaverhead Mountains (fig. 1), although the greater part of it lies along their west flank. The Continental Divide follows the crest of these mountains and that part of the area which lies to the west is in Lemhi County, Idaho, and that part to the east is in Beaverhead County, Mont. The district, as shown on plate 1, covers 155 square miles. It is bounded on the west by the broad Lemhi Valley. No such definitive boundary occurs to the east, so the eastern boundary arbitrarily has been placed beyond the easternmost known veins. The northern boundary is similarly placed north of most of the known veins. The southern boundary is more definite, ending to the southwest at Lemhi Valley and to the southeast against the Peterson Creek thrust fault. The Lemhi store and post office are in the Lemhi Valley on the southwest corner of the district; the Tendoy store and post office lie on the west edge of the area, 8 miles to the north. State Route 28 , which connects these two villages, joins U.S. Route 93 in the town of Salmon 19 miles northeast of Tendoy. The village of Leadore is on State Route 28, 19 miles south of Lemhi. The principal road across the district is a graded dirt one, which in part follows the old Lewis and Clark trail and connects Tendoy with Interstate Route 15 at Clark Canyon Reservoir dam, 28 miles east of the east border of the district. Dillon is the principal nearby town in Montana, 18 miles northeast of the Clark Canyon Reservoir. A poor secondary road extends along the Continental Divide from Lemhi Pass to the northern flank of Goat Mountain. A road branches from this road and follows the ridge on the east side of Bear Creek, and another road leaves the Continental Divide and follows a ridge between the South Fork of Yearian and Reese Creeks. This narrow road is connected with the valley by a series of switchbacks that in part follow the northwest side of Reese Creek. In addition there are other dirt roads along parts of Cow, Yearian, North Frying Pan, South Frying Pan, Bear, Sheser, Reese, and Pattee Creeks, a road up Ramsey Mountain, as well as roads to various springs, propsects, and timbered areas. Travel on some parts of these roads requires a four-wheel-drive vehicle.

\section{PHYSICAL FEATURES}

The Beaverhead Mountains are in the southern part of the Bitterroot Range, which forms a great part of the boundary between Idaho and Montana. The name Beaverhead Mountains is applied to the part south of Lost Trail Pass, where U.S. Route 93 crosses the Bitterroots north of North Fork, Idaho. The Lemhi Pass thorium district is in the north-central part of the Beaverhead Mountains. The backbone of the area is the Continental Divide, which rises to peaks almost 11,000 feet above sea level north of the district and from there descends southward to the broad Lemhi Pass at 7,373 feet in the northern part of the district. Southward from the Lemhi Pass the divide gradually rises to about 9,400 feet near the head of Peterson Creek. The highest peak, however, is Goat Mountain, which lies just south of the Continental Divide in the southeast corner of the district. This mountain forms a steep barren pyramid of rock that rises to an elevation of 9,943 feet between Peterson and Little Eightmile Creeks.

The land to the east of the Continental Divide in Montana is higher than that to the west in Idaho. The lowest point to the east of the divide has an elevation of approximately 6,580 feet and is at the east edge of plate 1 on Trail Creek. The lowest elevation to the west of the divide is less than 4,700 feet and it is along the Lemhi River. The difference in elevation can be seen by following the Lemhi Pass road which follows a gentle grade up Trail Creek in Montana to within 300 feet of the pass and then climbs up three gentle switchbacks. On the Idaho side the road pitches steeply 


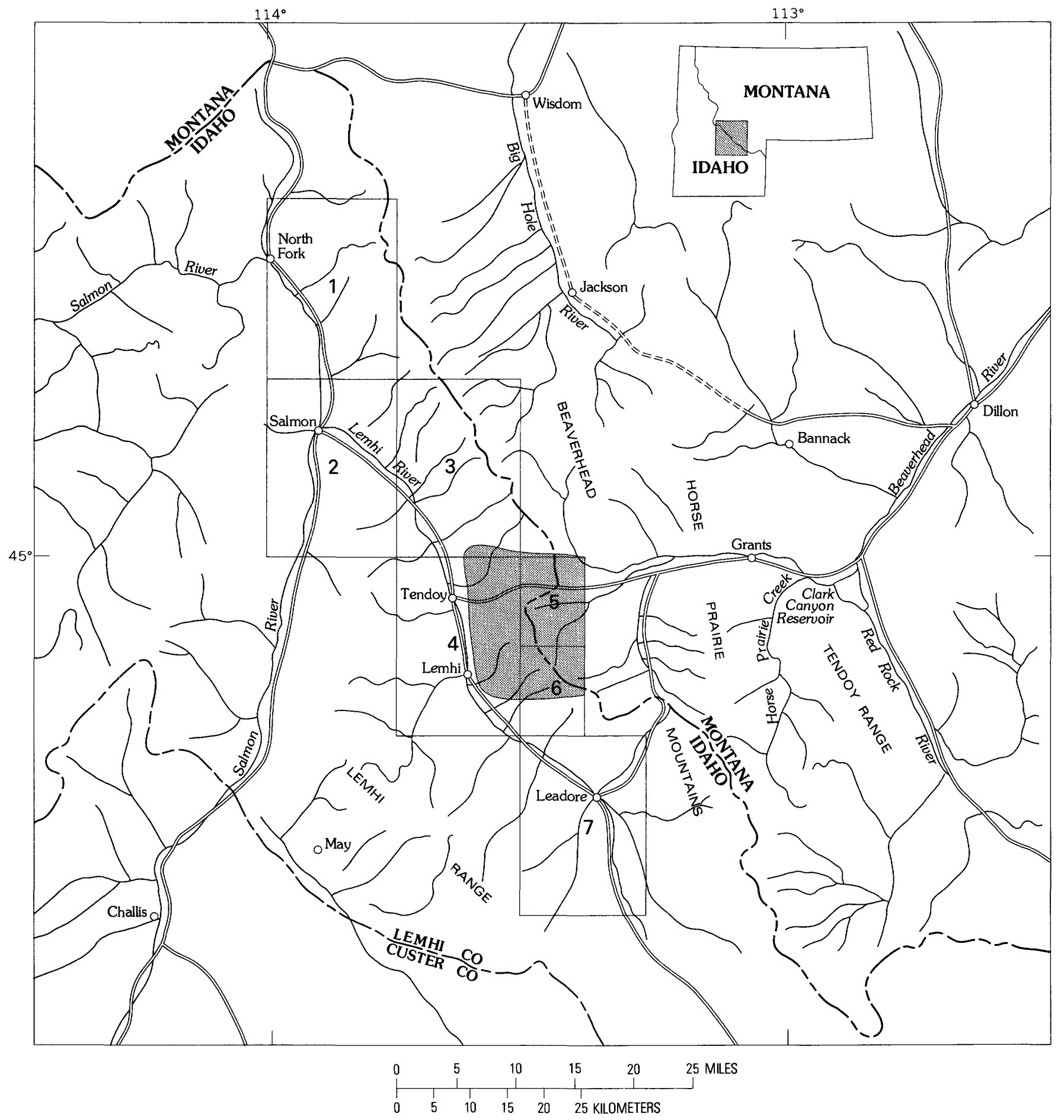

Figure 1.--Index map of eastern ldaho and southwestern Montana showing location of the Lemhi Pass thorium district (shaded) and the following quadrangles that are mentioned in the text: 1, North Fork; 2. Salmon; 3, Baker (Goldstone Mountain); 4, Lemhi; 5, 1.emhi Pass; 6, Goat Mountain; and 7, Leadore.

downward and in the next 2.4 miles it drops 1,470 feet.

Along the east side of the divide topography becomes quite rugged south of Lemhi Pass, and between North Frying Pan Creek and Bear Creek the east side of the divide is scalloped by steep-walled cirques. The bottoms of these cirques are commonly 1,000 feet below the Continental Divide, and the streams, which head in them, flow eastward down U-shaped valleys.

West of the Continental Divide, although the mountains are steep-sided, they are commonly subdued and 
characterized by rounded ridges that rise steeply from narrow valley floors. South of Agency Creek, the area consists of two mountain masses. The main mountain mass rises to the east to the Continental Divide. Parallel to this mountain mass and along the east side of the Lemhi River is a second mountain mass 7.5 miles long. This separate mountain block is divided from the main part of the range by a broad lowland, whose northern part is occupied by north-flowing Cow Creek, and whose southern part is occupied by south-flowing Yearian Creek. This rugged second mountain mass reaches a maximum elevation of 8,171 feet near its southern end on Ramsey Mountain. To the north the crest is mainly between 7,200 feet and 7,800 feet or 2,500 to 3,000 feet above the floor of the adjacent Lemhi Valley.

The streams in the northern and central part of the area, to the east of the Continental Divide, flow southward or northeastward to Trail Creek; those in the southern part flow eastward down Black Canyon Creek. Both creeks are tributaries of Horse Prairie Creek which flows eastward to Clark Canyon Reservoir (fig. 1). Slopes west of the Continental Divide drain from north to south into Pattee, Agency, Yearian, Reese, Peterson, and Little Eightmile Creeks with the greater part of this area being drained by Agency and Yearian Creeks. All these creeks drain westward into the Lemhi River.

\section{CLIMATE AND VEGETATION}

The principal differences in climate in this area are due to differences in elevation. In the lower part of the country, along the Lemhi River and the lower parts of Pattee, Cow, and Yearian Creeks, the climate is semiarid. Here snow rarely falls in significant amounts until December, and then is seldom more than a foot or two in depth. Snow disappears here in early spring. Annual precipitation is only 12 inches a year. In the mountains along the Continental Divide, 2,500-4,000 feet higher, the climate is much cooler, and may even be subalpine. Here snow is common in early autumn, although it does not accumulate in significant amounts until late autumn. It commonly remains on the ground until early summer and scattered drifts occur on the higher ridges as late as July. Summers are generally dry, but regional storms may bring several consecutive days of rainy. weather.

Summer temperatures along the Lemhi Valley commonly reach into the nineties, but in the high mountains it is $20-25^{\circ} \mathrm{F}$ cooler with chilly nights. Winter temperatures are coldest in December and January and average daily temperatures during these two months are $10^{\circ}-20^{\circ} \mathrm{F}$ below freezing at lower altitudes. Lowest annual temperature is generally from $-20^{\circ}$ to $-40^{\circ} \mathrm{F}$.

The vegetation reflects the differences in altitude, climate, water retention, and rock type. The drier low country is covered with low-growing sage (Artemisia tridentata), various grasses, and over 20 species of wild flowers. Along the valleys below 6,600 feet, especially those containing streams, are found western chokecherry (Prunus virginiana), dwarf maple (Acer glabrum), balsam poplar (Populus balsamifera), wild rose (Rosa woodsii), red osier dogwood (Cornus stolonifera), gooseberry (Ribes inerme), mountain alder (Alnus tenuifolia), brown birch (Betula occidentalis), elderberry (Sambucus coerulea), and several kinds of willow. In the drier streambeds rabbit brush (Chrysothamnus nausesus) is commonly abundant. Syringa (Philadelphus lewisii), ninebark (Physocarpus capitatus), and snowberry (Symphoricarpos occidentalis) are found in shaded areas along north-facing streams at an elevation of about 6,500 feet. Soil formed on older glacial deposits is richer in nutrients than that on most other rock types, as grass, sage, and flowers growing on the former are bigger and more abundant. Sage, grass, and flowers also clothe most of the mountains at moderate elevations, and evergreens appear on sun-shielded north-facing slopes. The growth of trees on these slopes is not so much a function of elevation and climate as it is of water retention. Winter snows are here protected from the direct rays of the sun and melt and evaporate much more slowly than those on other slopes. Douglas-fir (Pseudotsuga menziesii) makes up most of the evergreens to an elevation of about 7,000 feet. Scattered currants (Ribes viscosissimum) are commonly found on the same mountain sides. Above this elevation lodgepole pine (Pinus contorta var. latifolia) is common, and this tree covers most of the forested ridges in the Montana part of the district. Along the tops of ridges, above an elevation of 8,400 feet, limber pine (Pinus flexilis) is the common tree, and in places with it is found alpine fir (Abies lasiocarpa). Aspen (Populus tremuloides) occurs in damp hollows on many mountains of moderate to high elevation. Along the streams above about 6,500 feet elevation are found Engelmann spruce (Picea engelmanni), mountain alder (Alnus tenuifolia), and several types of willow.

Forested areas in general occur in the higher parts and on north-facing slopes of areas that have a moderate elevation. In those areas that lie close to the normal transition between open and forested country, rock type may be the controlling factor. In such places, trees are more common on Precambrian $\mathrm{Y}$ sedimentary rocks than they are on the Challis Volcanics. An excellent example occurs in a roughly triangular patch of volcanic rocks in the northeastern part of the district between South Frying Pan and Bear Creeks. This patch is for the most part unforested, but it is surrounded by forest-covered areas that are underlain by Precambrian rocks or covered with glacial till.

\section{PREVIOUS WORK}

The earliest known work in the Lemhi Pass thorium district was a brief description of the Copper Queen mine in 1910 by Umpleby (1913, p. 120-121), as a part of a much larger study on the precious and nonferrous metal mining 
districts of Lemhi County. Thorium discoveries were first reported by Vhay $(1951$, p. 11-14) in a short paper on a reconnaissance for uranium in Idaho and Montana. Short descriptions of veins on various prospects were given by Anderson (1958, p. 45-74; 1960; 1961a), Jarrard (1957, p. 46-47), Moen (1957, p. 7-23), Schipper (1955), Trites and Tooker (1953, p. 195-208), and Weis, Armstrong, and Rosenblum (1958, p. 36-39). More detailed work was made on a number of individual properties. Armstrong (1956) reported upon the results of a drilling program on the Last Chance property in Montana under a U.S. Defense Minerals Exploration Administration contract, and Shively (1960) described beneficiation tests on ore from the Cago No. 12 vein. The first description of the general geology of the district was by Sharp and Cavender (1962), who compiled a planimetric map from aerial photographs at a scale of 1:24,000. This work was done in 1952 before many of the now known properties had been discovered and covers a little more than half of the present district.

During the early 1960's R. P. Geach made a study of the mining properties of Beaverhead County, Mont. In a special report (1966) on thorium deposits he included mine maps of the two adits on the Last Chance property. Between 1964 and 1966 B. J. Sharp and D. L. Hetland of the U.S. Atomic Energy Commission (now the Department of Energy) studied all the major veins in the Lemhi Pass district. They published a brief summary of the geology of the area (Sharp and Hetland, 1968) which included two reconnaissance maps at a scale of 1:62,500. The maps, which covered an area of approximately 600 square miles, extended from the Mineral Hill mining district, 22 miles northwest of Salmon, Idaho, to Dry Canyon, 11.5 miles southeast of Leadore. Analytical data on samples they collected from many properties were published by Austin (1968). Later, Austin, Hetland, and Sharp (1970) gave a brief description of the mineralogy of some of these deposits. Metallurgical amenability tests on some of the samples collected by Sharp and Hetland were made by the U.S. Bureau of Mines (Ross and George, 1966). In addition to the study of mining properties, a general geologic study of the Lemhi 15-minute quadrangle was made by Anderson (1961b). The report of this area, whose eastern part overlaps about half the Lemhi Pass thorium district (fig. 1), is accompanied by a reconnaissance map at the scale of 1:62,500.

Although considerable work had been done on various thorium veins, with emphasis on their size, shape, and grade, little work had been done on the relation of the veins to the regional geology. Furthermore, owing to the small grain size of most of the minerals in the veins and the masking of various minerals by abundant red and yellow iron oxides, the mineralogy of the veins was poorly known. In order to better understand these veins, I made a detailed study of the Lemhi Pass quadrangle (fig. 1) in 1968 and 1969. The results of this work were reported in three papers: (1) A bulletin describing the geology and thorium-bearing veins of the area
(Staatz, 1972), (2) a paper on the occurrence of rare earths in these veins (Staatz and others, 1972), and (3) a paper on geochemical prospecting for thorium using stream-sediment samples (Staatz and others, 1971). Work continued southward during one month in 1970 and all of the summer of 1971 and resulted in a map of the Goat Mountain quadrangle (Staatz, 1973).

\section{PRESENT INVESTIGATIONS AND ACKNOWLEDGMENTS}

The present work is a study of the entire Lemhi Pass thorium district. The mapped area (pl. 1) takes in all known veins in this area except at three localities, which are at a distance from other veins. The Daisy Nielsen vein is on the Nielsen Ranch near the headwaters of Sandy Creek about 5 miles north of the area shown on plate 1 and about that far from the nearest other known thorium vein. The Lorado and Ruth veins lie 0.75-1 mile north of McDevitt Creek, approximately 8.3 miles southwest of Tendoy, which is on the west edge of the district. Plate 1 is made up of all or parts of four topographic maps: (1) The entire Lemhi Pass $71 / 2$-minute quadrangle, (2) the northern third of the Goat Mountain $71 / 2$-minute quadrangle, (3) the northeast part of the Lemhi 15-minute quadrangle, and (4) a few square miles along the southern border of the Goldstone Mountain quadrangle. All mapping was done directly on topographic maps at a scale of $1: 24,000$ and later reduced to $1: 31,680$ for the final map. The eastern half of the area, which includes the Lemhi Pass and Goat Mountain quadrangles, was published previously at a scale of $1: 24,000$ (Staatz, 1972; 1973). Aerial photographs were used to help locate postion, especially in areas of scattered timber. Overburden is thick in many places and outcrops are few; hence, position of contacts between units had to be inferred in many places.

A second part of the work is a detailed study of the veins. All veins were investigated using a scintillation counter, and all those of even moderate radioactivity were sampled for analysis and mineral identification. The individual minerals within the veins were isolated by means of heavy liquids, hand magnet, magnetic separator, and hand picking. Those not readily recognizable were identified by X-ray. B. J. Sharp and D. L. Hetland of the U.S. Atomic Energy Commission mapped and sampled many of the veins in 1965 . Some of the workings they mapped have since sloughed in, and the veins in these areas are no longer exposed. In other areas new workings have been opened and other parts of the veins are exposed. To show the greatest amount of data on various veins, many of their maps have been revised to show new workings as of 1973 or 1974. The section entitled "Description of selected thorium veins" was written by Staatz but also includes much data from Sharp and Hetland.

The Lemhi Pass thorium district was mapped between 
1967 and 1974. In 1967 I was assisted in the field by Eric Loeb, in 1968 by Duane R. Packer, in 1969 by Robert A. Langford, and in 1970 by Eric C. Grimm.

I would like to acknowledge help by E. T. Ruppel of the U.S. Geological Survey on the Precambrian Y sedimentary rocks. J. W. Adams aided me with advice on the rare-earth and thorium minerals. M. W. Sullivan and I. K. Brownfield helped with some of the mineral separations.

\section{ROCKS OF THE DISTRICT}

Rocks of the Lemhi Pass thorium district are of four principal types: (1) Fine-grained clastic sedimentary rocks of Precambrian Y age, (2) limestone of Mississippian age, (3) volcanic rocks and sedimentary rocks having a volcanic component, of Tertiary age, and (4) unconsolidated deposits of Quaternary age. The Precambrian Y rocks consist principally of micaceous or feldspathic quartzite interbedded in places with siltite. These rocks underlie the entire area but are poorly exposed over about 60 percent of it. Above the Peterson Creek thrust fault and west of the Yearian Creek graben the Precambrian $\mathrm{Y}$ rocks resemble those mapped by Ruppel (1968) in the adjoining Leadore quadrangle to the south, and were subdivided similarly. Below the thrust the Precambrian Y rocks are divided on the basis of their lithology. The Mississippian rocks are the Madison Limestone and are principally confined to small areas southeast of the Peterson Creek thrust. The Tertiary rocks consist of the Challis Volcanics and the tuffaceous sedimentary rocks. The former are made up principally of dark flow rocks but also contain some tuff and conglomerate. These rocks were emplaced in the early Tertiary and at one time probably covered the entire area. Directly following this period of volcanism was a major period of diastrophism, which uplifted and downdropped various parts of the Challis Volcanics. Subsequent erosion has stripped away most of these volcanic rocks, and only about 15 percent of the area now is underlain by this rock type, which is found principally in downfaulted blocks (fig. 2). The tuffaceous sedimentary rocks are mainly of lacustrine origin and were deposited in mountain basins during middle Tertiary time. They consist mainly of fine-grained tuffaceous sedimentary rocks containing layers or lenses of conglomerate. These rocks formed after most of the faulting and they are found still in broad topographic lows. Diorite dikes and small intrusives, also of Tertiary age, intrude the Precambrian Y sedimentary rocks. The Quaternary rocks are widespread and entirely mask the underlying rocks in about 20 percent of this district. Eight unconsolidated units have been mapped: (1) Older glacial deposits, (2) younger glacial deposits, (3) terrace deposits, (4) alluvial fans, (5) landslide deposits, (6) a rock glacier, (7) a mudflow, and (8) alluvium. Most of these are limited to local areas in or near valley bottoms. The older glacial deposits at one time, however, covered the entire area, and they still cover broad

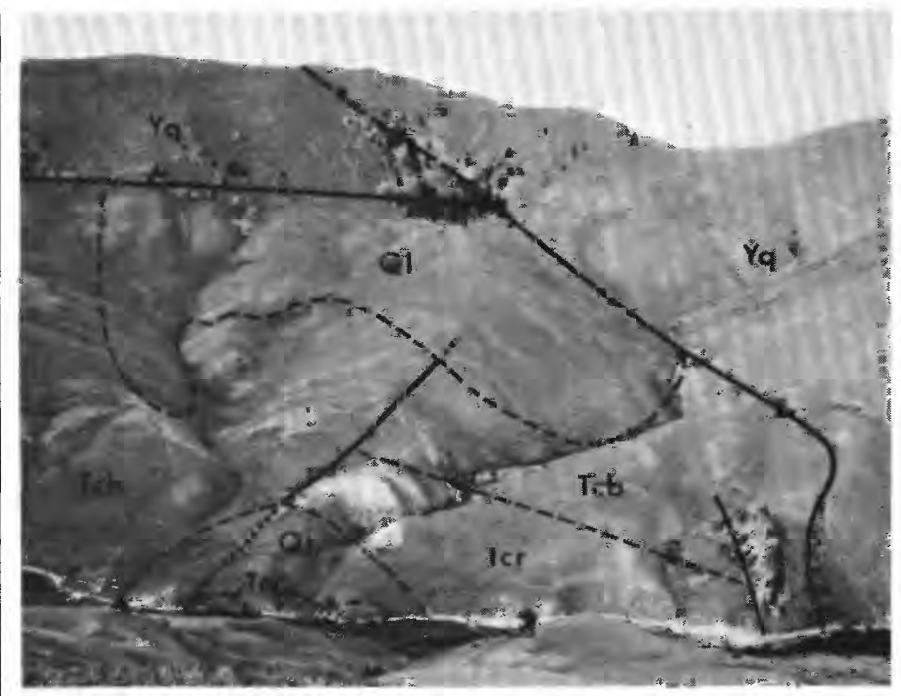

Figure 2.-Downfaulted block of Challis Volcanics surrounded by Precambrian $\mathrm{Y}$ quartzite $(\mathrm{Yq})$ on the north side of Agency Creek opposite the mouth of Sharkey Creek. Units in Challis Volcanics are basalt-rhyodacite sequence $(T c b)$ and the tuff of Curtis Ranch $(T c r)$. Landslide deposits shown as QI and terrace deposits as Qt

areas, such as the northeast corner of the district and along the Cow Creek-Yearian Creek trough, where they either have been in part protected from erosion or were originally quite thick.

\section{PRECAMBRIAN Y SEDIMENTARY ROCKS}

The greater part of the Lemhi Pass thorium district is underlain by quartzite and siltite of Precambrian $\mathrm{Y}$ age. These rocks underlie much of the Beaverhead Mountains extending at least as far northward as Lost Trail Pass and as far southward as Long Canyon in the southernmost part of this range (Ruppel, 1975, p. 21). They also make up a large part of the Lemhi Range and the Salmon River Mountains (Ruppel, 1968; 1975; Anderson, 1956, p. 16-18; 1957, p. $14-15 ; 1959$, p. 19-25). The Precambrian Y sedimentary rocks form an exceedingly thick section and in the Lemhi Range Ruppel $(1975$, p. 1) estimates that they are more than 40,000 feet thick. These rocks were first recognized as Precmabrian in this part of Idaho by Umpleby (1913, p. 30-32) who later assigned them to the Belt Series (1917, p. 23).

Although the rocks of Lemhi County can be broadly correlated with the Belt rocks of northern Idaho and western Montana, direct correlation of any particular part appears impractical (Anderson, 1956, p. 18; Ross, 1962, p. 20). Both areas contain thick sections of fine-grained clastic rocks, but in detail they have little in common. The grain size of most of the rocks in western Montana and northern Idaho corresponds to medium silt or finer (Harrison and Campbell, 1963 , p. 1415), but that of the greater part of the rocks in the Lemhi area is a fine to medium sand. Limestone and dolomite make up a major part of the Wallace Formation, a 
unit in the central part of the Belt Supergroup, to the north, but are nearly absent to the south. Many shallow-water features such as mud cracks, ripple marks, cut-and-fill structures, and mud-chip breccia are common to the north (Harrison and Campbell, 1963, p. 1415-1416) but are rare to the south. Thus, subdivision of the rocks in east-central Idaho has been largely independent of that of the better known Belt rocks in northern Idaho and western Montana. I have correlated the Precambrian sedimentary rocks in the Lemhi Pass district with the Belt Supergroup in previous reports (Staatz, 1972, 1973), but Ruppel (1975, p. 15-16) has since pointed out that the Precambrian sedimentary rocks in northwestern Montana and east-central Idaho were deposited in different basins and received sedimentation from different sources. He $(1975$, p. 18) further notes that both were probably deposited during Precambrian Y time, although correlation is based mainly on a few significant events that apparently affected both the Belt Supergroup rocks of northwestern Montana and the Precambrian rocks in the Beaverhead Mountains.

The Precambrian Y sedimentary rocks have been subdivided in various places in east-central Idaho. Ross (1934, p. 16-18) introduced the name Yellowjacket Formation for about 8,500 feet of dark-gray micaceous quartzites near the small mining town of Yellowjacket. He (1947, p. 1096-1099) later named and described two other formations on the west-central flank of the Lemhi Range, the Lemhi and Swauger Quartzites. Anderson studied the Precambrian Y rocks along the west side of the Beaverhead Mountains and the east side of the Lemhi Range when he mapped the Salmon, Baker ${ }^{1}$, and Lemhi quadrangles (Anderson, 1956, p. $16-18 ; 1957$, p. 14-15; 1961 b, p. 19-25). In the Salmon and Baker quadrangles he did not attempt to subdivide them but in the Lemhi quadrangle he divided them into three formations. He used the names Lemhi and Swauger Quartzites for his uppermost two units and added a new name, the Apple Creek Phyllite, for the lowest unit, which he described as being made up of phyllite and phyllitic quartzite. In the western part of the Lemhi Pass thorium district, which is part of the Lemhi quadrangle, Anderson (1961b, pl. 1) has mapped both Lemhi and Swauger Quartzites. His map shows the two formations commonly separated by low-angle thrust faults, which he infers ( $1961 \mathrm{~b}$, p. 66) from the irregular contact discordances of the northeast and northwest structures and from apparent disappearances of the northeast-trending folds under those of northwest trend. The strike and dip of the quartzite beds show some variance, but no folds were noted in this western part of the district during my mapping, nor are any folds shown on the map of Anderson (1961b, pl. 1). Furthermore, the rocks exposed in areas mapped as Swauger are mostly identical to those in adjacent areas mapped as Lemhi.

'On the published topographic sheet, the Baker quadrangle is designated the Goldstone Mountain quadrangle.
Ruppel, working mainly in the Lemhi Range, has mapped the Precambrian $Y$ sedimentary rocks in three 15-minute quadrangles: Leadore (Ruppel, 1968), Gilmore, and Patterson. On the basis of his work in these areas he (1975) has (1) changed the lithologic ending of the Swauger Quartzite to Swauger Formation, (2) changed the stratigraphic rank of the Lemhi Quartzite to Lemhi Group and divided it into five formations, which in ascending order are: Inyo Creek Formation, West Fork Formation, Big Creek Formation, Apple Creek Formation, and Gunsight Formation, and (3) geographically extended the name Yellowjacket Formation into the Lemhi Range and Beaverhead Mountains. The Apple Creek Formation is a modification of the lithologic ending of Apple Creek Phyllite of Anderson (1961b). Ruppel $(1975$, p. 10) notes that the rocks that overlie the Apple Creek in its type area and which Anderson calls Lemhi Quartzite are a part of the Yellowjacket Formation, and are here thrust over the phyllite, and that the Apple Creek actually occurs near the center of the Lemhi Group. The other formations in Ruppel's Lemhi Group are new. The lowest two formations of the Lemhi Group, the Inyo Creek and the West Fork, are known only in relatively small areas in the southern part of the Patterson quadrangle in the Lemhi Range. The other three formations are much more widespread, occurring in various areas in the Lemhi Range and Beaverhead Mountains. Two of these formations, the Gunsight and Big Creek, consist principally of gray fine-grained feldspathic quartzite and are separated by the Apple Creek, which is principally a siltite. In many areas of isolated outcrop where the Apple Creek is missing the Gunsight cannot be distinguished from the Big Creek.

Exposures over a great deal of the area in the Beaverhead Mountains occupied by the Lemhi Pass thorium district are much fewer than those in the Lemhi Range and farther north in the Beaverhead Mountains. Unlike the other two areas, outcrops are generally widely scattered, and even on steep slopes exposures are commonly poor. In much of the area the topography is also subdued and rounded. Furthermore, many parts of the Lemhi Pass area are partly or completely covered by glacial deposits. Boulders and pebbles in glacial fill in this area consist mainly of fine-grained quartzite from the Precambrian $\mathrm{Y}$ rocks. Thus, in many areas it is not possible to determine whether quartzite float was derived from the underlying bedrock or brought in from a distant location. In making the present study I used only bedrock outcrops for determining the position of the Precambrian Y sedimentary rocks.

The area of best exposure is shown in the southeast corner of plate 1 on and adjacent to Goat Mountain. In this area along Peterson Creek and Black Canyon is the large Peterson Creek thrust fault. South of this fault the Precambrian $Y$ sedimentary rocks are different from those to the north. This area is part of the Goat Mountain quadrangle (fig. 1), which has been previously mapped (Staatz, 1973) and adjoins the Leadore quadrangle on the north (Ruppel, 
1968). The Lemhi Group and Swauger Formation as used by Ruppel $(1975)^{2}$ have been traced northward into the present map area south of the thrust (pl. 1). Similar rocks have been found on Ramsey Mountain west of the Yearian Creek graben and south of a fault along the south side of Agency Creek. Directly north of the Peterson Creek thrust and east of Ramsey Mountain the quartzite tends to be micaceous instead of feldspathic and may be part of the thick Yellowjacket Formation. Ruppel (1975, p. 21) suggested that the rocks he saw on a visit to Lemhi Pass also resembled those in the Yellowjacket Formation. Many of the Precambrian $Y$ rocks north of the Peterson Creek fault are micaceous quartzite, but not all. In several areas thick siltite units are found. Faulting in the Precambrian Y rocks is not distinguishable unless some marker unit such as a siltite bed is offset or the fault trace can be delineated from where it also offsets younger rocks. The stratigraphy of the Precambrian $Y$ rocks north of the Peterson Creek fault and east of the Yearian Creek graben is further clouded by several thick siltite units. Lithologically the siltites are fairly similar to each other, but the relations to some of the bounding rocks suggest they are different. A thick greenish-gray siltite lies adjacent to and northeast of the Peterson Creek thrust (fig. $3 D$ ) near the junction of the Left Fork and Right Fork of Peterson Creek. This unit is abruptly overlain by a greenish-gray quartzite, whose green color is due to chlorite. In the northern part of the area, along the north side of the Lemhi Pass fault, a light-gray to black siltite is also overlain by a greenish-gray quartzite. Here the contact is gradational and the green color is due to epidote. In a third area along the Continental Divide about 3 miles due north of the first area, a greenish-gray siltite is underlain by a greenish-gray quartzite. This contact is abrupt and the color of the quartzite is due to chlorite.

The Precambrian Y sedimentary rocks above the Peterson Creek thrust (pl. 1) and on Ramsey Mountain were divided into the Big Creek, Apple Creek, and Gunsight Formations of the Lemhi Group and the Swauger Formation. In the rest of the area, however, the Precambrian Y rocks were simply divided lithologically into either quartzite or siltite.

\section{ROCKS ABOVE THE PETERSON CREEK THRUST FAULT AND ON RAMSEY MOUNTAIN}

The Precambrian $\mathrm{Y}$ sedimentary rocks in this area are represented by four formations from the upper part of these rocks: The Big Creek, Apple Creek, and Gunsight Formations of the Lemhi Group, and the Swauger Formation. All these units are separated from one another by faults.

\section{BIG: CREEK FORMATION}

The Big Creek Formation makes up about half of the area south of the Peterson Creek thrust fault including most of

\footnotetext{
When the Goat Mountain quadrangle report was completed. names had not been given to the various formations in the Lemhı Group, and the upper three formations in the Lemhı Group are identified on this map as units B, C, and D.
}

the very precipitous Goat Mountain (fig. $3 A$ ). This quartzite is extremely hard and commonly forms a series of cliffs. In most places it is medium bedded; in a few places it is thick bedded to massive. Shallow-water features are generally absent, although ripple marks are present near the north end of the Goat Mountain ridge. The Big Creek is principally a quartzite, although in some places a few thin siltite beds are present (fig. $3 B$ ). The quartzite varies in color and may be light gray, gray, tan, brown, greenish gray, or green. Much of the quartzite on Goat Mountain weathers brown. The quartz grains range from angular to rounded, and in most layers they are fairly well sorted. Many of the layers in this rock are made up of fine-grained sand but some have medium-grained sand. In one specimen the grains ranged from 0.0014 to 0.023 in. in diameter. The grains in most of the layers, however, range from about 0.005 to $0.012 \mathrm{in}$., and, according to Wentworth (1922, p. 381), would be classified from a very fine sand to a medium sand. The greater part of the quartzite is feldspathic and this rock commonly contains 4-12 percent feldspar as small white grains. Plagioclase is the predominant feldspar, although in some specimens microcline is common. Sericite in amounts as much as 10 percent, but generally less, is a common mineral. Some specimens also contain as much as 5 percent of tiny grains of pale-green wispy chlorite. Small grains of chert in a mounts as much as several percent occur in most layers. In addition, a few grains of tourmaline and zircon are found in most specimens, and trace amounts of apatite, leucoxene, and hematite occur in some.

\section{APPLE CREEK FORMATION}

The Apple Creek Formation is exposed only east of the Lemhi River along the west edge of Ramsey Mountain. It can be traced just east of Lemhi for 5 miles to the north to the mouth of Big Dry Gulch. The base is not exposed and the upper part is separated by a small fault from the overlying Gunsight Formation. The maximum exposed thickness along this outcrop is about 1,400 feet. The Apple Creek is fairly well exposed, forming a series of small rust-stained cliffs along the base of the mountain front. The Apple Creek Formation varies in color from light gray to a pale greenish gray. It is thin bedded and in places also finely laminated. This rock is a fairly well sorted siltite, having an average grain size of about $0.001 \mathrm{in}$. In a few places there are thin gray layers of fine-grained quartzite. The siltite consists principally of subangular to subrounded grains of quartz. In addition it contains small amounts of biotite, sericite, and feldspar.

\section{GUNSIGHT FORMATION}

The Gunsight Formation makes up most of the Ramsey Mountain front along the west margin of the Lemhi Pass thorium district (pl. 1). It is also found in an area between the Peterson Creek thrust fault on the north and a normal fault along the Continental Divide on the south in the southeast part of the district. The Gunsight makes up the greater part 

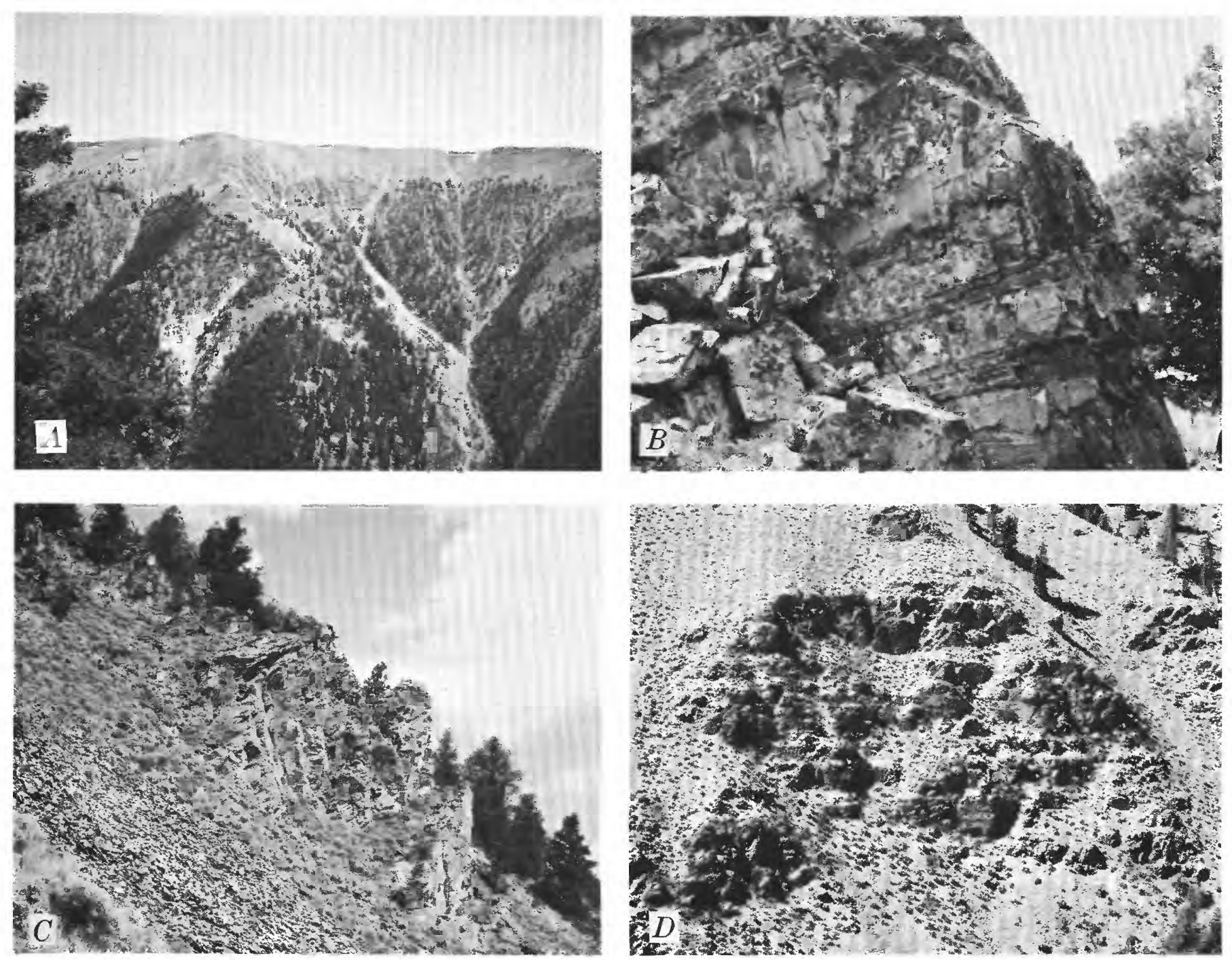

Figure 3. - Precambrian Y rocks. A, View of Goat Mountain looking southeast across the Right Fork of Peterson Creek. Cliffs of quartzite of the Big Creek Formation. B, Big Creek Formation on the southeast side of Little Eightmile Creek showing light-gray quartzite with thin dark-gray siltite interbeds. $C$, Ledges of Swauger Formation along the steep north face of Mollie Gulch about 2 miles south of the Lemhi Pass district. $D$, Siltite exposed along the steep northwest side of the left fork of Peterson Creek.

of the Ramsey Mountain block. The lower part of the Gunsight is separated from the underlying Apple Creek Formation by a small fault, as indicated by divergent strikes and dips in several places. The amount of movement on this fault is small. Ruppel $(1975$, p. 11) notes that the lower Gunsight contact is gradational through 200-300 feet of interbedded quartzite and siltite beds. Similar interbedding of quartzite and siltite beds is well exposed just above the fault on the ridge north of Little Dry Gulch. The upper part of the Gunsight is cut out by faulting. The greater part of the Gunsight Formation is quartzite, although widely scattered greenish gray siltite beds crop out in a few places, mainly in the lower 1,000 feet of this formation. The quartzite is a gray to light-gray fine- to medium-grained rock, whose individual grains are subangular to subrounded in shape. The quartzite is generally feldspathic, containing as much as 25 percent feldspar. In some beds in the Ramsey Mountain block and along the Continental Divide, the quartzite lacks feldspar; these beds are generally quite resistant and have a greasy luster. The quartzite commonly has sericite. This mineral is most common in those beds having little feldspar. Accessory minerals include tourmaline, zircon, biotite, magnetite, limonite, and hematite. Magnetite is more abundant in the area south of the Peterson Creek thrust. In the Ramsey Mountain area it is commonly scarce, although minute specks of hematite and limonite in some beds may have formerly been magnetite. The Gunsight Formation south of the Peterson Creek thrust is commonly somewhat darker and more commonly banded than is the quartzite in the Ramsey Mountain block. 


\section{SWAUGER FORMATION}

The Swauger Formation is found only at the southern boundary of the area adjacent to the east side of the Peterson Creek thrust fault. Not only is this formation on the upper plate of the Peterson thrust, but it is separated from the other rocks in the upper plate by another thrust. Exposures here are generally poor, but this formation is much more extensive and better exposed a few miles to the southeast (Staatz, 1973) (fig. 3C). The part of the Swauger exposed here, whose total thickness is more than 10,000 feet (Ruppel, 1975 , p. 12), is not known. The Swauger in this area is generally medium grained, although in places it is fine grained. The individual grains are generally well rounded and the rock commonly has a glassy appearance. This unit is generally white to light gray, although some sericitic quartzite layers are pale green. The quartzite consists mainly of quartz; a few layers may contain a little feldspar. Crossbedding was noted in several places. In comparison to the two quartzites in the Lemhi Group, the Swauger is cleaner, lighter colored, and the grains are somewhat coarser and better rounded.

\section{ROCKS BELOW THE PETERSON CREEK THRUST FAULT AND EAST OF RAMSEY MOUNTAIN}

The Precambrian $\mathrm{Y}$ rocks below the thrust consist predominantly of fine-grained quartzite. Siltite occurs both as thin beds within the main quartzite sequence and as moderately thick units. Thin siltite layers, which for the most part range from half an inch to 1 foot thick, are found in only certain parts of the quartzite sequences. In many areas siltites are not found. Thick units of siltite (fig. 3D) are found widely scattered in this area (pl. 1). They are commonly more than 1,000 feet thick, and may have a few thin quartzite layers but for the most part are of siltite. These thick siltite units are of great aid in determining the position of many faults and are mapped separately (pl. 1).

\section{QUARTZITE}

Quartzite in the Lemhi Pass district has a general sameness of appearance, yet there are differences in color, grain size, and mineral content from place to place. Some of these differences occur from layer to layer, but others are found from place to place. The greater part of the rocks north of Agency Creek and in the northeastern part of the district are either light or medium gray; a few are greenish gray or white. In the southeast part of the district north of the Peterson Creek thrust, greenish-gray, green, or olive-green beds are common. These greenish beds generally are interbedded with those of gray or light-gray, although in some places they change color along the same layer. In some areas, such as between Yearian and Peterson Creeks, the green quartzite beds commonly are interbedded with thin greenish-gray siltite units. The quartizite is generally fine grained, although a few layers may be either medium grained or very fine grained (0.001 to 0.020 in.). Sand grains are generally well sorted and subangular to subrounded in shape. Quartzite generally is thin to medium bedded, and most beds range from 3 inches to 2 feet in thickness. Here and there are found a few massive layers as much as about 10 feet thick. Crossbedding occurs in a few places but is most common in the Agency Creek basin between Flume Creek and the Continental Divide.

In much of the northeastern part of the area, the gray quartzite is micaceous rock that contains but little feldspar. For the most part these rocks consist of 60-80 percent quartz, 5-30 percent sericite, $1-10$ percent biotite, and less than 1-8 percent plagioclase. In addition some contain as much as 5 percent, but generally about 1 percent, chlorite. Small round grains of hematite or magnetite occur in some specimens. A grain or two of tourmaline was found in almost every thin section, and trace amounts of zircon and apatite are common. The micas, which generally are aligned parallel to their clevage, give the rock its foliation. Sericite, biotite, and chlorite form a mesh around the quartz grains. The three micas appear to be of metamorphic origin.

The color of the green, greenish-gray, or olive-green quartzite in most places is due to chlorite. These rocks may contain 10-25 percent chlorite. They also commonly contain small amounts of biotite. The green of the quartzite that overlies the siltite north of the Lemhi Pass fault in the Flume Creek area is due to epidote. These rocks have 10-20 percent epidote, less than 1-2 percent chlorite, but no biotite or plagioclase. The gray quartzite in this area has about 10 percent plagioclase, and the epidote is probably derived from metamorphism of the original plagioclase in the rock, possibly during movement of the Lemhi Pass fault. This is one of the few areas in which epidote was noted in the quartzite.

Feldspathic quartzite occurs in the Black Canyon and Continental Divide areas in the southeastern part of the district (pl. 1), in the area north of Agency Creek in the northwestern part of the district, and in some other smaller scattered areas. The feldspathic rocks may have $8-35$ percent combined plagioclase and orthoclase. The sericite content is commonly low and may drop from the average elsewhere of 15 percent to 5 percent. A few rocks adjacent to the Continental Divide in the headwaters of Black Canyon and Bear Creeks have both a high feldspar and a high sericite content-about 20 percent of each. Much of the sericite in feldspathic rocks occurs as tiny laths on the feldspar, which it partially replaces. Thus, the sericitic quartzite was probably feldspathic when originally deposited, and the potassium feldspar has been converted to sericite during later metamorphism.

\section{SILTITE}

Most of the siltite in the Lemhi Pass district is a shade of green-pale green, olive green, or greenish gray. Some, however, is gray or black. Siltite that is interbedded with 
gray to light-gray quartzite is generally gray to light gray, that with greenish-gray quartzite is generally greenish gray or green. The siltite, where it occurs in thick units, is commonly better exposed than the quartzite (fig. $3 D$ ). In some areas such as along the lower part of Peterson Creek, it forms small cliffs (fig. $3 D$ ). Siltite generally occurs in thin beds, which, in addition, may be finely laminated. Laminations chiefly vary in being different shades of gray or green, but may also consist of slightly different grain sizes.

The siltite is a dense rock composed of tiny subangular to subrounded grains that are fairly well sorted. Average grain size varies between beds and is from 0.0004 to 0.002 in., the overall average being about 0.0006 in. The siltite beds may include scattered grains as much as $0.008 \mathrm{in}$. across (very fine sand).

The composition of the siltite is similar to that of the quartzite, although because of the finer grain size, the feldspar grains are generally difficult to distinguish from the quartz grains. The siltites generally contain $50-80$ percent quartz, less than 1-2 percent plagioclase, 7-35 percent sericite, 1-3 percent biotite, 1-15 percent chlorite, and a trace to 2 percent magnetite. Trace amounts of tourmaline, zircon, and apatite are present in some specimens. Tourmaline is especially notable, as small amounts are found in almost every sample. Chlorite is responsible for the green color found in some siltites. Gray siltites generally have less than 1-2 percent chlorite, but greenish-gray to green siltites have 7-17 percent chlorite. A dark-gray to black phyllite is found at the Lucky Horseshoe property (loc. 1) just north of the Lemhi Pass fault. The phyllitic character of this rock is apparently due to dynamic metamorphism of siltite during faulting. Away from the fault the beds become lighter gray and finally greenish gray and the character of the rock changes from that of a phyllite to a siltite. Another outcrop of phyllite was noted interbedded with quartzite on a small tributary of Reese Creek adjacent to a fault. A similar change takes place on Apple Creek in the southwest part of the Lemhi quadrangle, the type area of Anderson's Apple creek Phyllite (1961 b, p. 19-21). Here Ruppel (1975, p. 10) notes that the phyllitic character of the Apple Creek is due to shearing beneath a thrust fault and in other areas this rock is a siltite.

\section{MISSISSIPPIAN MADISON LIMESTONE}

The Madison Limestone occurs only south of the Peterson Creek thrust in the southeast corner of the area (pl. 1). Rocks in the upper plate of this thrust are faulted over each other in a series of lesser thrusts (fig. 12B) (Staatz, 1973), and the Madison is thrust over the Big Creek Formation of the Lemhi Group. The Madison Limestone occurs in many places in the Beaverhead Mountains southeast of the Lemhi Pass district (Ruppel, 1968) but is not found to the northwest. Thus, the Madison outcrops, as shown on plate 1 , are the northernmost exposures of the formation in this range.
Only part of the Madison Limestone is exposed in the Lemhi Pass thorium district and perhaps 1,000 feet of it are shown on plate 1 . In the Leadore quadrangle to the south it is also found in small fault blocks and slices. There Ruppel (1968, p. 3) estimated that its original thickness may have been 2,500 feet. In the Leadore quadrangle and in the southern part of the Goat Mountain quadrangle (Staatz, 1973), it is overlain by the Big Snowy Formation of Late Mississippian age and underlain by the Milligen(?) Formation. Since 1975 the name Milligen has been restricted to the Wood River area of Idaho (Sandberg and others, 1975), and the strata previously called Milligen(?) have been renamed the McGowan Creek Formation of Mississippian age (Sandberg, 1975).

The upper part of the Madison Limestone consists chiefly of thick-bedded to massive light- to medium-gray limestone. This rock is commonly coarse grained, although it may be medium grained. In part it is bioclastic and contains a few horn corals. Some beds contain a little gray or black chert and have a fetid odor. Lithologically this limestone resembles the Mission Canyon Limestone of southeastern Idaho. The lower part of the Madison is made up chiefly of a thin-bedded medium- to dark-gray limestone. It may also be bluish gray and generally weathers to light gray. This limestone is fine grained and commonly contains lenses or nodules of grayish-black or brown chert. The chert lenses are flat and range in thickness from 0.5 to 1.5 inches. In places the limestone contains sparse brown-weathering silt grains. The lower part of the Madison is similar to some of the rocks in the Lodgepole Limestone in southeastern Idaho and southwestern Montana.

Although the massive light-gray limestone is found principally in the upper part and thin-bedded darker gray limestone in the lower part, some thin-bedded limestone occurs in the upper part and some massive limestone in the lower part.

In one small area north of the mouth of Reese Creek in the south-central part of plate 1 the Madison Limestone has been almost entirely silicified. Here the rock consists of black to dark-gray chert breccia made up of angular pieces of chert set in a chert matrix. In one small gully remnants of the original limestone were found. Similar silicified limestone occurs in the southern part of the Goat Mountain quadrangle (Staatz, 1973) and in the adjoining Leadore quadrangle (Ruppel, 1968). In these areas the chert breccia directly overlies thrust faults. The chert breccia is believed to have formed by brecciation of the limestone along the thrust, followed by introduction of silica. The area of silicified Madison Limestone on plate 1 is on strike and a little more than 2 miles northwest of a large thrust fault mapped in the Goat Mountain quadrangle. The thrust, which is not exposed in the intervening covered area, is the probable cause of brecciation of this small area of Madison Limestone. 


\section{TERTIARY CHALLIS VOLCANICS}

The Challis Volcanics were first described by Ross in 1927 (p. 7-9) in the Salmon River Mountains, but the name was first used in 1930 in a paper on four small mining districts in Custer and Camas Counties, Idaho (Ross, 1930, p. 1, 10, 23). This formation, which was named after the town of Challis, originally included all of the Tertiary volcanic rocks of central Idaho. Ross (1961) later restricted the Challis to dominantly volcanic strata of early Tertiary age within the part of central Idaho north of the Snake River Plain and south of the westward-flowing segment of the Salmon River. Volcanic rocks are found along the Salmon River northward from the town of Challis past the town of Salmon; they are also found from Salmon to the southeast along the Lemhi River, which joins the Salmon River at Salmon, at least as far as Leadore (Anderson, 1956, pl. 1; Anderson, 1957, pl. 1; Anderson, 1961b, pl. 1; Staatz, 1974; Ruppel, 1968). Thus the Challis Volcanics can be traced fairly continuously from the type locality to the Lemhi Pass area. Although volcanic rocks are found along the valleys of the two rivers just mentioned, the outcrops are not continuous, commonly being in isolated fault blocks. Furthermore, the lithology of the units is somewhat different in the several areas. Ross (1962, p. 75) divided the Challis into a latite-andesite member, basalt and related flows, the Germer Tuffaceous Member, and the Yankee Fork Rhyolite Member near the town of Challis. He noted that Yankee Fork was not strictly uniform either in character or in stratigraphic position. Anderson (1956, p. 18-28), mapping in the Salmon quadrangle, found a lower latite-andesite unit and an upper tuffaceous unit with intercalated latite, rhyolite, and basalt flows. This upper unit he correlated roughly with the Germer Tuffaceous Member. The units are not equally distributed, the latite-andesite unit being present only in the southern part of the Salmon River drainage and the upper tuffaceous unit only in the northern part and in all of the Lemhi River drainage. East of the Salmon quadrangle, in the Baker (Goldstone Mountain) quadrangle, Anderson (1957, p. 16) gives only the briefest description of the Challis Volcanics, but south of this area in the Lemhi quadrangle he $(1961 \mathrm{~b}, \mathrm{p}$. 43-53) divided the Challis Volcanics into a lower unit of latite and andesite, an intermediate unit of pyroclastics, basalt, and basic andesite, and an upper unit of basalt. Farther south in the Lemhi Range, south-southwest of Leadore, Ruppel (1968) divided the Challis into lower basaltic rocks and upper latitic and andesitic rocks. Both units contain interbedded tuffs. Thus the volcanic rocks, preserved in many places along the principal drainages in much of the area from the town of Challis to the Lemhi Pass district are seen to vary in detail from place to place. In other words, although volcanism was common over a wide area in east-central Idaho during early Tertiary time, flows and ash falls commonly were local in extent.

In the Lemhi quadrangle, Anderson (1961b, p. 43-53) proposed that the Challis be raised in rank to the Challis Volcanic Group and that his lower unit be named the Cheney Volcanics, his intermediate unit the Yearian Volcanics, and his upper unit the Kadletz Volcanics.

As has been noted, the lithologic units of the Challis Volcanics are commonly of local extent. For example, the many tuffaceous units that occur with dark-colored flow rock in the northern part of the Lemhi Pass district (pl. 1) pinch out and are not found in the southern part of the district. Thus, volcanic units of considerable importance as marker beds at a particular locality may have little regional significance. I do not feel that the Challis Volcanics should be upgraded to group status because it can be subdivided in a particular place into several divisions of one or more local units. The name Challis Volcanics has, therefore, been retained in this report as a formational name. Furthermore, the descriptions of the new formations-Cheney Volcanics, Yearian Volcanics, and Kadletz Volcanics-given by Anderson (1961 b, p. 41-53, pl. 1) do not agree in many places with data I obtained during the present study. As approximately the western half of the Lemhi Pass thorium district lies in the eastern part of the Lemhi quadrangle, which was mapped by Anderson (1961 b, pl. 1), direct comparison can be made of these units. Anderson (1961b, p. 44) describes the Cheney Volcanics as an easily recognized unit of relatively light-colored latite and andesite possessing a sparkly appearance on fresh surfaces. The formation contains some andesitic and rhyolitic tuff, rhyolite, and rhyolitic ignimbrite (welded tuff). Most of this formation lies in the western half of the Lemhi quadrangle and was not examined, but several square miles of this formation were mapped in the northeast corner of the Lemhi quadrangle. Here, approximately the eastern half of this formation consists of a thick conglomerate, the western part a white quartzite-bearing rhyolite tuff, and the northern part a drab dark-brown flow rock overlaid in places by a white welded tuff. The dark-colored flow rock is similar to that mapped farther south as Yearian Volcanics, and the white welded tuff is separated by an angular unconformity from the other rocks. Anderson (196lb, p. 48-49) noted that the Yearian Volcanics are "characterized by a general preponderance of pyroclastic materials and, in most places, by only minor intercalations of andesitic and basaltic flows." This is the principal volcanic unit mapped by Anderson in the Lemhi quadrangle and is well represented in the eastern part of the quadrangle. Detailed mapping of these volcanics, however, indicates that more than three-quarters of them are represented by dark flow rocks. Furthermore, one of the larger pyroclastic units in the Yearian Volcanics in this area is a quartzite-bearing rhyolite tuff mapped north of Pattee Creek. This distinctive unit is identical to one mapped between Poison Creek and Agency Creek as part of the Cheney Volcanics. The third formation - the Kadletz Volcanics-occurs only in a small area in the western part of the Lemhi quadrangle, and thus does not occur in the Lemhi Pass thorium area (pl. 1). The 
formations used by Anderson are not used in the present study owing to the lack of correlation between his descriptions and those of the volcanics in the area under study. Instead, the Challis Volcanics are divided informally on the basis of their local lithology.

\section{DISTRIBUTION}

The Challis Volcanics are scattered widely over the Lemhi Pass thorium district (pl. 1). The greater part of them, however, are found in two areas: (1) A north-south strip from the Lemhi Pass fault in the north along part of Agency Creek and the Cow Creek and Yearian Creek valleys, and (2) south of the Lemhi Pass fault in Montana in the northeast part of the district. At one time the Challis Volcanics probably covered most of the district. Much of it has since been eroded away, and that part preserved is generally in down-dropped fault blocks (fig. 2). A series of north-, northwest-, and northeast-trending faults bound the Challis Volcanics in the north-south strip south of the Lemhi Pass fault (fig. 13B). The volcanics to the south along Yearian Creek lie in a faulted graben (fig. 13C). Some of the volcanic rocks in the northeastern part of the district are bounded on the northeast by the large Lemhi Pass fault and on the southwest by the Bull Moose fault. Two other areas of northeast-dipping volcanics a mile south of these outcrops are bounded on the northeast by the Dan Patch fault. Volcanics in the northwest corner of the district are bounded to the east by the Pattee Creek fault.

In a few small areas the Challis Volcanics are preserved in low spots in the prevolcanic topography. One of the largest such areas is in a hollow formed over a pre-Tertiary fault that lies along the Continental Divide near the southeast corner of the Lemhi Pass district. Several volcanic remnants also occur along a main ridgetop at the head of the North Fork of Everson Creek. In a few areas the relation between the Challis Volcanics and the underlying bedrock is not known. One of these areas is in the northeast corner of the district where several units of Challis Volcanics are exposed along the sides of steep draws in an area otherwise blanketed by older glacial deposits. A somewhat similar occurrence is found on the north side of Peterson Creek where exposures of dark flow rock protrude through fan deposits.

\section{ROCK TYPES}

The Challis Volcanics can be divided into rocks of two, and possibly three, divisions on the basis of their relative ages. The oldest rocks are in the first division and consist of a thick basalt-rhyodacite sequence and associated tuff and conglomerate. These rocks make up more than 90 percent of the Challis Volcanics and are further subdivided into seven units. A second division contains light-purple, pink, and brown quartz latite flows or intrusive bodies. These rocks substantially differ in appearance from other volcanic rocks in the district. They occur as scattered outcrops in the northeast, extending from near the mouth of Flume Creek to the east edge of the district (pl. 1). Most outcrops are surrounded by glacial deposits, although the contact of the quartz latite body just west of Lemhi Pass with other volcanics is poorly exposed. Distribution of the outcrops of this rock relative to those of the adjacent tuff indicate that the quartz latite most likely intruded the tuff. That these rocks were deposited prior to mid-Tertiary tectonism is indicated by steep dips of some of the quartz latite flows. These rocks may either be a part of the preceding division or they may be part of a distinct division as here discussed. The third division contains younger basalt and a sandine-quartz welded tuff. Both were emplaced after much of the mid-Tertiary tectonism, and overlie rocks of the first division with angular unconformity (fig. 4). Both rock types, in their respective areas, have been cut by the Dan Patch fault, but the welded tuff must also, in part, overlie the fault, as the offset of this rock type is not as great as the older units of the Challis Volcanics. Thus, the welded tuff was laid down after much but not all of the movement occurred along this fault.

The rocks of the oldest division were divided on the basis of their lithology into the following seven units: (1) Basal conglomerate, (2) quartzite-bearing rhyolite tuff, (3) conglomerate of Flume Creek, (4) vitric tuff of Lemhi Pass, (5) basalt-rhyodacite sequence (including rhyolitic tuff beds), (6) tuff of Curtis Ranch, and (7) a flow-breccia unit (fig. 4). Unit 5 , the basalt-rhyodacite sequence, is the most common and most widespread unit, and in the southern part of the district it is the only unit exposed. The other units pinch out to the south. The only possible exception is unit 7 , the flow-breccia unit, which is similar in places to unit 5 . These two units are distinguished by their position below and above unit 6, the tuff of Curtis Ranch. If the tuff is missing, the two units could not be distinguished and whether both units occur in the southern part of the map area, where the tuff is missing, is not known. The rocks of this oldest division apparently correspond to the basaltic rocks mapped by Ruppel (1968) in the lower part of the Challis Volcanics.

Many of the units in the volcanic rocks vary considerably in thickness (fig. 4). The conglomerate of Flume Creek thins from more than 1,000 feet near the mouth of Flume Creek to about 20 feet on Lemhi Pass, 2.8 miles east. The quartzite-bearing rhyolite tuff is at least 1,700 feet thick along the Continental Divide south of Lemhi Pass, but pinches out to the south. The basalt-rhyodacite sequence overlies the first four units in the vicinity of Lemhi Pass but to the south along Trapper Creek, on the Continental Divide north of Goat Mountain, and to the west along Cow Creek, the basalt-rhyodacite sequence directly overlies the Precambrian $\mathrm{Y}$ rocks. Thus, some of the rock units here used, although of great aid in unraveling the local structure, are of little significance in regional correlations. 


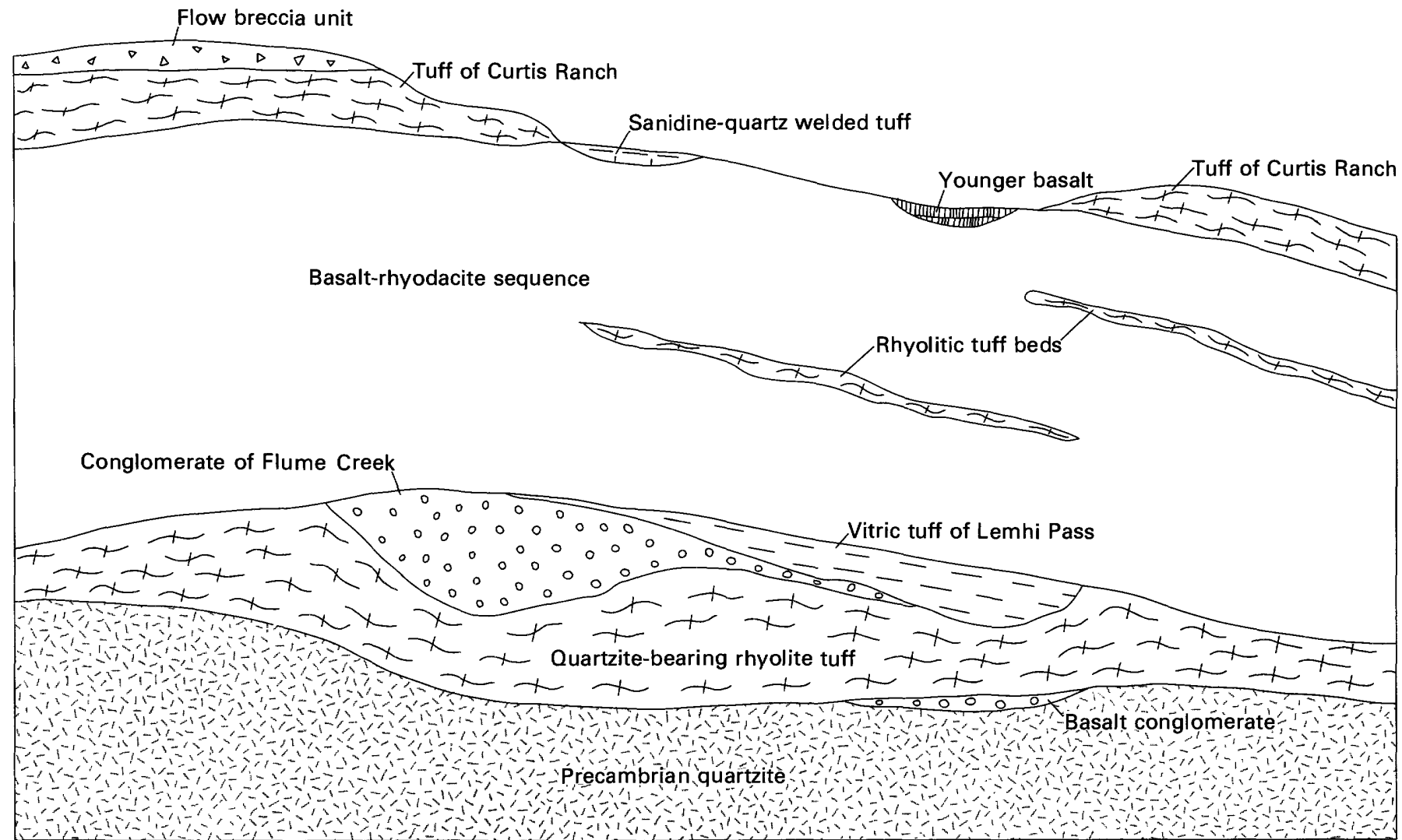

Figure 4.-Diagrammatic cross section of the Challis Volcanics across the northern part of the Lemhi Pass thorium district. No scale is implied; directions are general.

\section{BASAL CONGLOMERATE}

The basal conglomerate is the oldest unit of the Challis Volcanics and grades upward into the quartzite-bearing rhyolite tuff. This unit is exposed only in one small area, 0.5 mile west to 1 mile southwest of Lemhi Pass, where it lies along the west edge of the Challis outcrop in this area. Here the basal conglomerate is thin and intermittent, never more than 15 feet thick. A conglomerate at or close to the base of the Challis Volcanics is reported by Ross $(1962$, p. 74) in mappable amounts in many localities. Anderson (1959, p. 21-22) noted a thick conglomerate at the base of the volcanics along the Salmon River south of North Fork, which he called the Kriley Formation.

The basal conglomerate in the Lemhi Pass area is made up of well-rounded pebbles and cobbles set in a white tuffaceous matrix. This matrix may make up less than 5 percent of the rock in the lower part of the unit, but increases in abundance toward the top where it may make up as much as 80 percent of the rock. Micaceous Precambriam Y quartzite makes up most of the pebbles and cobbles. White tuff makes up some of the smaller pebbles, and a gray glassy quartzite, probably from the Ordovician Kinnikinic Quartzite, is the rock type of a few pebbles. Matrix is commonly of ash, although siliceous cement is present in a few places.

\section{QUARTZITE-BEARING RHYOLITE TUFF}

The quartzite-bearing rhyolite tuff overlies the basal conglomerate southwest of Lemhi Pass, but in other areas it directly overlies the Precambrian Y rocks. This tuff is overlain by the conglomerate of Flume Creek at Lemhi Pass and about 1 mile east-southeast of the mouth of Flume Creek. South and west both the conglomerate of Flume Creek and the tuff of Lemhi Pass are not present, and in these areas the quartzite-bearing rhyolite tuff is directly overlain by the basalt-rhyodacite sequence (pl. 1; fig. 4). The rhyolite tuff is found across the northern part of the Lemhi Pass thorium district in scattered fault blocks from northwest of Pattee Creek to northeast of Sheser Creek (fig. $5 A$ ). This unit pinches out southward and is not found in the southern half of the area. The thickness of the quartzite-bearing tuff is variable, and in many places its total thickness is difficult to determine owing to either glacial cover or faults that cut out part of the unit. It is more than 1,000 feet thick northwest of Pattee Creek in sec. 11, T. 19 N., 


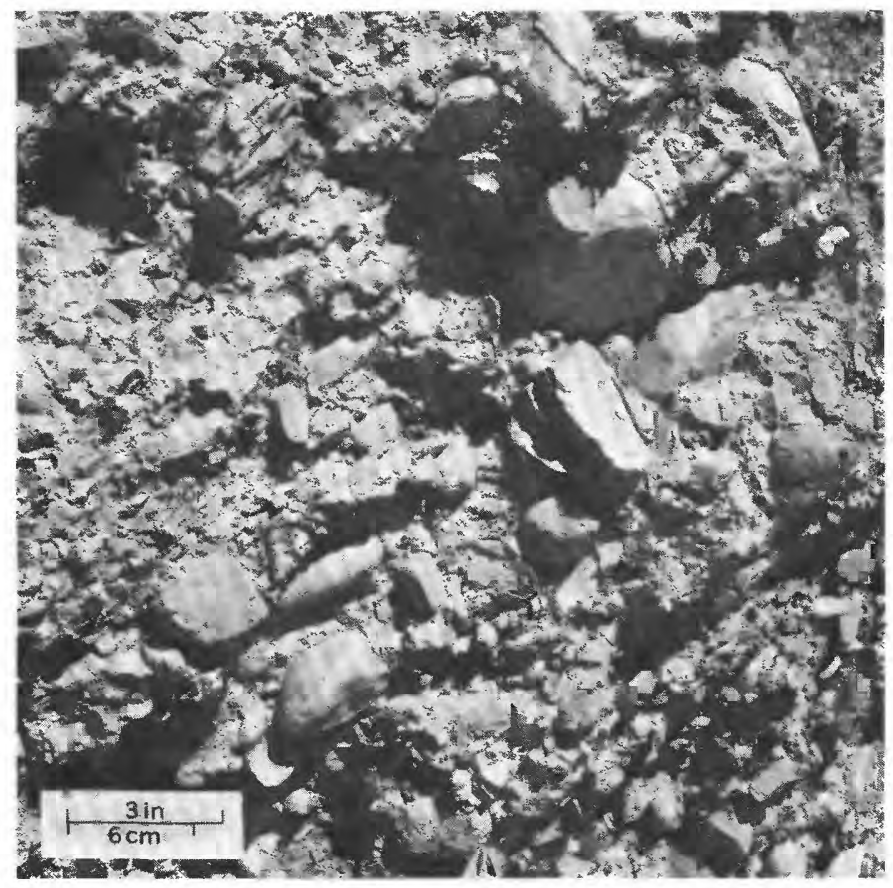

Figurk 6.--Conglomerate of Flume Creek along the north side of Agency Creek west of the mouth of Flume Creek. Well-rounded pebbles and cobbles are mainly of brown volcanic rock.

quartzite, although in some areas purplish-gray and brown plagioclase porphyries are more abundant. A few pebbles are of siltite, white vein quartz, and red quartzite. The matrix is a mixture of white ash and a few sparse crystal fragments. Quartz is the most abundant of these, but they also include biotite, sanidine, and plagioclase. In places the ash matrix is altered to a greenish-white clay.

The sandstone layers within the conglomerate are generally medium grained. The principal clasts are quartz and red or brown aphanitic volcanic rock, but some are of plagioclase, sanidine, siltite, biotite, and augite. The matrix may be of ash or of chalcedonic cement.

The conglomerate of Flume Creek is similar in appearance to the basal conglomerate and to conglomerates found in the younger tuffaceous sedimentary rocks.

\section{VITRIC TLFF OF LEMHI PASS}

The vitric tuff of Lemhi Pass is rather local in extent and where present lies intercalated with the underlying conglomerate of Flume Creek and the basalt-rhyodacite sequence (fig. 4). It occurs only in the northern part of the Lemhi Pass thorium district from the south side of Lemhi Pass to the northwest for 3.8 miles to a point 0.9 mile northwest of the mouth of Flume Creek, where it is cut off by the Dan Patch fault. This unit thickens along its outcrop trend to the southeast. In the vicinity of Flume Creek it is approximately 380 feet thick but on the east side of Lemhi Pass it has a minimum thickness of 720 feet. The tuff of
Lemhi Pass, as well as the underlying conglomerate of Flume Creek, pinches out abruptly to the south, and 1 mile southeast of Lemhi Pass the basalt-rhyodacite sequence lies directly on the quartzite-bearing rhyolite tuff (pl. 1).

The vitric tuff of Lemhi Pass is a white to greenish-white dense rock made up principally of ash and a few rock and crystal fragments. Rock fragments are generally rounded and are $0.06-0.5$ inch across. Because they are mainly tuff fragments of the same material as the matrix, they are inconspicuous. A few percent of the rock fragments on the east side of Lemhi Pass consists of granule-size pieces of gray micaceous quartzite. Small sand-size crystal fragments make up a minor part of this rock. They are principally quartz and plagioclase, but biotite is moderately common in the westernmost exposures. The ash consists of numerous glass shards set in a similar appearing clear glass. The vitric tuff contains at least a moderate amount of potassium, which is indicated by the bright yellow color obtained when this rock is stained by sodium cobaltinitrite.

\section{BASALT-RHYODACITE SEQUENCE}

The basalt-rhyodacite sequence is the thickest and most widespread unit of the Challis Volcanics in the Lemhi Pass thorium district (pl. 1). This unit near Lemhi Pass is separated from the Precambrian Y sedimentary rocks by the tuff of Lemhi Pass, the conglomerate of Flume Creek, the quartzite-bearing rhyolite tuff, and the basal conglomerate. To the west along Agency and Pattee Creeks these two conglomerates and the tuff of Lemhi Pass have pinched out, and the rhyodacite-basalt sequence overlies the quartzite-bearing rhyolite tuff (fig. 4). To the south the rhyolite tuff also pinches out, and the basalt-rhyodacite sequence directly overlies the Precambrian rocks. The basalt-rhyodacite sequence is overlain by the tuff of Curtis Ranch (fig. 7A), and is one of three units in the three divisions of the Challis containing dark-colored volcanic rocks. The other two, the flow-breccia unit and the younger basalt, are found in relatively small areas where they lie above the basalt-rhyodacite sequence. The basalt-rhyodacite sequence makes up more than half of the area underlain by the Challis Volcanics and in most of the southern part of the area it is the only part of the Challis present. Although the basalt-rhyodacite unit is found scattered in many parts of the district (pl. 1), it is most common in three areas: (1) In the eastern part of the district near the junction of Trail, Frying Pan, Trapper, and Bear Creeks; (2) a 4-mile-long northern-trending band from Ghoul Basin across Agency Creek to upper Cow Creek; and (3) a 2.5-mile-long north-trending area astride Yearian Creek in the southern part of the district. The basalt-rhyodacite sequence is generally bounded on one or more side by faults and the entire sequence is only exposed along the southeast side of Trapper Creek. Here these rocks are approximately 3,300 feet thick. 

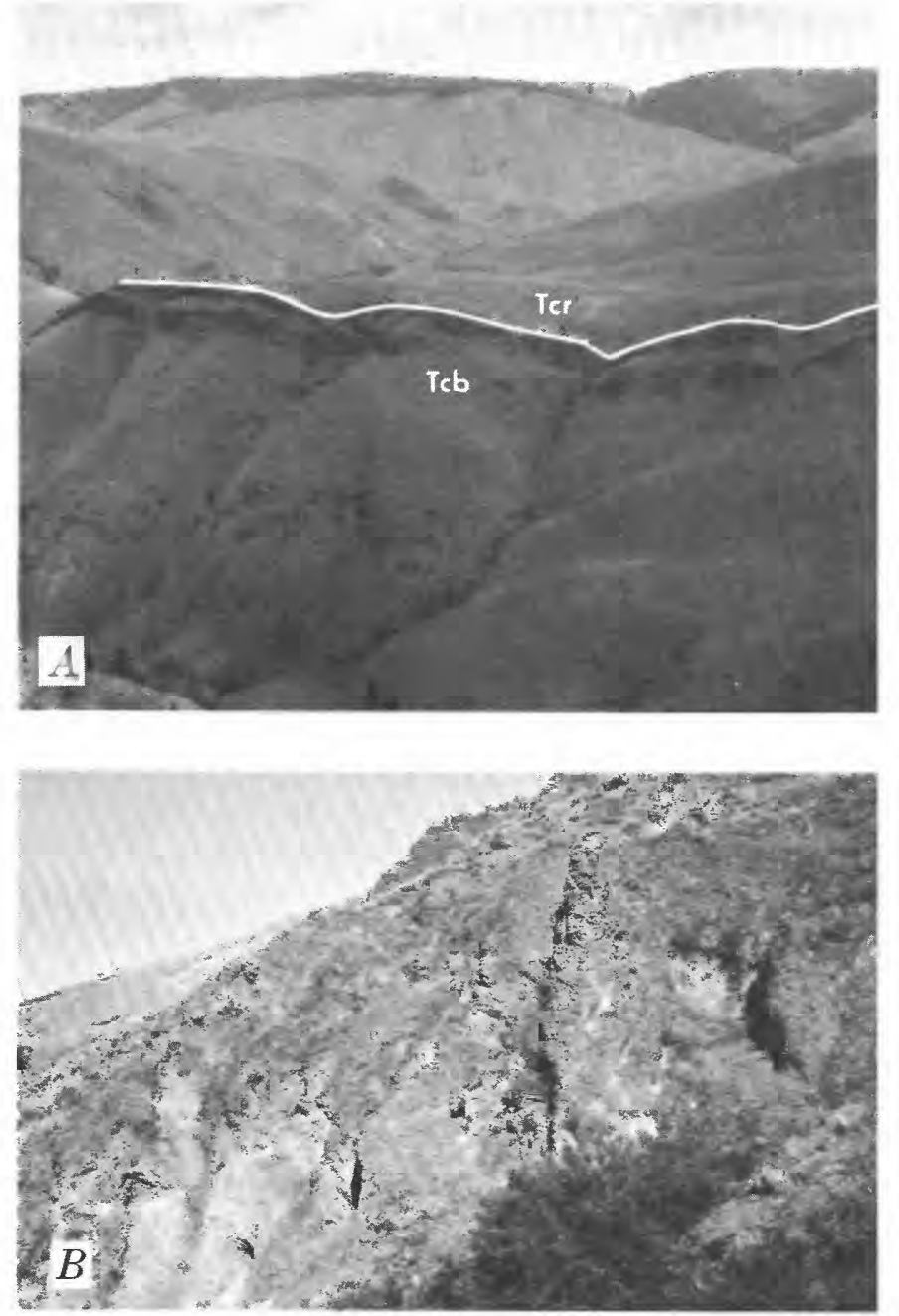

FIGURE 7.-Basalt-rhyodacite sequence. $A$, Dark flows form prominent ledges at top of basalt-rhyodacite sequence $(\mathrm{Tcb})$, which is overlain by tuff of Curtis Ranch (Tcr). Picture taken looking northeastward across Cow Creek. B, Massive flow crops out on north side of Agency Creek. C. Road along Agency Creek follows stream cut through thick basalt flow. Picture looking northeastward near mouth of Sharkey Creek, $D$, Prominent outcrop of flow breccia on northwest side of Agency Creek 0.75 mile northeast of mouth of White Creek.

The basalt-rhyodacite sequence is made up principally of dark-colored aphanitic flows (fig. $7 B$ and $C$ ) with flow breccias occurring intermittently near the base of individual flows, and thin light-colored rhyolitic tuff units scattered through the sequence. The flow rocks may be black, dark olive green, dark gray, gray, purplish gray, brown, or hematitic red. Many of them weather to a dark russet. The color of these rocks, which range in composition from basalt to rhyodacite, tends to be darker (black or dark olive green) in the more mafic rocks and lighter (gray to hematitic red) in the more silicic rocks. All the rocks are dark colored and fine grained and are not readily separable on the basis of their appearance in hand specimen. In general the most mafic rocks occur in the lower half of the sequence in the eastern
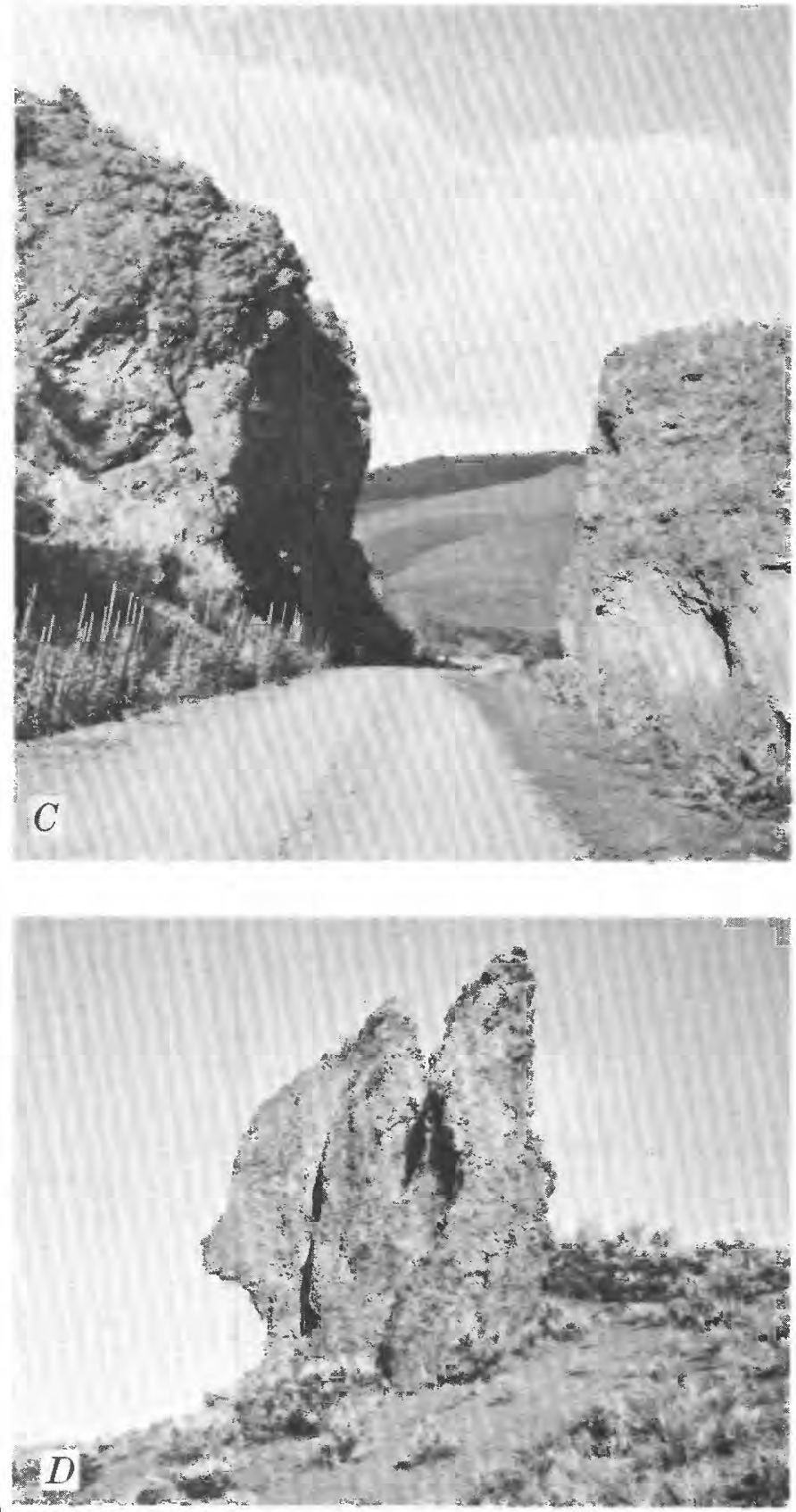

part of the area; the flow rocks in the western part of the area are principally quartz latite. The tops of some of the more silicic flows, especially in the eastern part of the area, are oxidized to a hematitic red color. Tops of some flows are also marked by numerous vesicles which range in length from 0.006 to $0.47 \mathrm{in}$. Some of the vesicles are filled with calcite or chalcedony.

The texture of the flow rocks is highly variable. Some of them have phenocrysts set in a fine-grained matrix, some have phenocrysts set in a glass, a few are fine grained but holocrystalline, and a few consist chiefly of glass containing some microlites. Phenocrysts, where present, make up 1-50 
percent of the rock. Dark-green augite is the principal phenocryst in many of these rocks although in the more mafic rocks the principal mineral may be olivine. The augite occurs in subhedral to euhedral crystals, and in highly altered rock the augite may be pseudomorphically replaced by limonite. Although augite is by far the most common pyroxene, in a few flows the pyroxene is pigeonite. Pale green glassy crystals of olivine occur in many basalts. In other places this mineral has been partly or completely altered to serpentine and bright-orange iddingsite and to a lesser extent to talc and chlorite. Other mafic phenocrysts are biotite and magnetite. Biotite is fairly common in the more siliceous rocks in the western part of the area but is scarcer in the eastern part. Magnetite is common in all rocks but only rarely forms large phenocrysts. Plagioclase is only rarely found as phenocrysts, although the matrix commonly contains either abundant small plagioclase crystals or plagioclase microlites. Some of the plagioclase was determined to be andesine by extinction-angle measurements on albite twins. The matrix may contain small distinct crystals or microlites of many of the same minerals that make up the phenocrysts. Here plagioclase is by far the most common mineral and the mafic minerals are subordinate. In addition a little potassium feldspar in small anhedral crystals occurs in some of these rocks. A pale-brown glass makes up part or all of the matrix in some of the rocks. The potassium content of the glass is roughly measured by staining with sodium cobaltinitrite. The results of this staining, ranging from no apparent staining to a deep-orange color, indicate a wide range in the potassium content.

Flow breccias occur intermittently along the base of some flows, especially in the northeastern part of the area. The breccias a re commonly more resistant to weathering than the flows of which they are a part and form prominent outcrops (fig. $7 \mathrm{D}$ ) that locally delineate the direction of flowage. Individual flow-breccia units range in thickness from a few feet to about 50 feet and in length from less than 100 feet to as much as 0.5 mile. The flow breccias are made up of angular to subrounded lava fragments which range in size from 0.062 inch to 3 feet across. The matrix consists of flow material similar in composition to the individual clasts.

Thin tuff layers of various types occur widely scattered throughout this unit. Most of the tuff layers are less resistant than the flows, and in most places they are poorly exposed. They vary in appearance; in color they may be white, gray, tan, pink, or orange, and in type they may be a crystal, crystal-vitric, or vitric tuff. All the tuffs are more silicic than the adjoining flows and most appear to be rhyolitic in composition. A crystal tuff is exposed for about 1 mile in the E $1 / 2$ sec. 18, T. 19 N., R. 25 E., just north of Agency Creek in Idaho. Other good examples occur in the SW $1 / 2$ sec. 22 and along the border between secs. 15 and 16 in T. 10 S., R. 15 W., in Montana. These tuffs contain 35-70 percent crystal fragments in an ash matrix. The crystal clasts in these three tuffs are principally plagioclase, with minor amounts of quartz and biotite. Some tuffs contain about equal amounts of crystal and vitric fragments and some are mainly vitric fragments, although most contain a few percent of crystal clasts. An easily accessible vitric tuff is found just west of the road up Yearian Creek in the $\mathrm{SE}^{1} / 4$ sec. 25, T. 18 N., R. 24 E., in the southwest part of the area. This rock consists of more than 75 percent rock fragments and as much as 10 percent crystal fragments set in partly devitrified ash. Most of the rock fragments are of volcanic glass, although a few percent of Precambrian Y quartzite or siltite clasts are generally present. Staining with sodium cobaltinitrite indicates that these tuffs have a high potassium content.

Six chemical analyses were made on this widespread unit of the Challis Volcanics (table 1). Considerable variation is found in the amounts of some of the oxides in these rocks-for example, $\mathrm{SiO}_{2}, \mathrm{MgO}, \mathrm{CaO}$, and $\mathrm{K}_{2} \mathrm{O}$. The normative compositions (table 1) show equally large variations. Two of the six rocks contain normative, as well as modal, olivine. The largest variation in chemical composition is found in the northeastern part of the area, where the three analyses (table 1 , samples 3,4 , and 5) range in rock type from trachybasalt to rhyodacite. Most of the olivine-bearing rocks are found near the base of the flows in this area, and the upper part of the sequence generally contains the highest amount of $\mathrm{SiO}^{2}$. The silica-rich sample, (table 1, no. 3 ) is a hematitic red rhyodacitic vesicular glass. As suggested by the color, most of the iron in this sample is in the ferric form. The rocks in the western part of the area are similar to each other in appearance and composition as is indicated by the analyses of three representative samples (table 1, nos. 6, 7, and 8 ). The anorthite content of the plagioclase, as calculated from normative albite and anorthite, ranges from 30 to 48 percent (andesine). In order to show better the relative abundance of some of the more important oxides in these rocks to one another, two diagrams were constructed. One (fig. 8) has $\mathrm{CaO}, \mathrm{Na}_{2} \mathrm{O}$, and $\mathrm{K}_{2} \mathrm{O}$ as end members, and the second (fig. 9) has $\mathrm{MgO}$ plotted against the total iron oxide content. ${ }^{3}$ The plot of the rocks of the basalt-rhyodacite sequence in figure 8 have a linear trend, with the proportion of $\mathrm{Na}_{2} \mathrm{O}$ remaining fairly constant. Two analyses of quartzite-bearing rhyolite tuff fall on this same trend, but the analysis of the tuff of Curtis Ranch is not on it. In figure 9 the plot of the rocks of the basalt-rhyodacite sequence shows another linear trend, with these rocks all having a high $\Sigma \mathrm{FeO}$ content and a widely variable $\mathrm{MgO}$ content. The plots of the three tuff samples, which have a much lower $\Sigma$ FeO content, are not on this trend. Analyses of suites of volcanic rocks from a single source in other regions also show a linear arrangement on similar diagrams, according to H. A. Powers (oral commun., 1960), but the lines may be in different position. On the other hand, the analyses of rocks

${ }^{3}$ The ratio of $\mathrm{FeO}$ to $\mathrm{Fe}_{2} \mathrm{O}_{3}$ varies considerably in volcanic rocks owing to inconsistent degree of oxidation. Hence, the $\mathrm{Fe}_{2} \mathrm{O}_{3}$ is converted to $\mathrm{FeO}$ and the total expressed as $\Sigma \mathrm{FeO}$. 


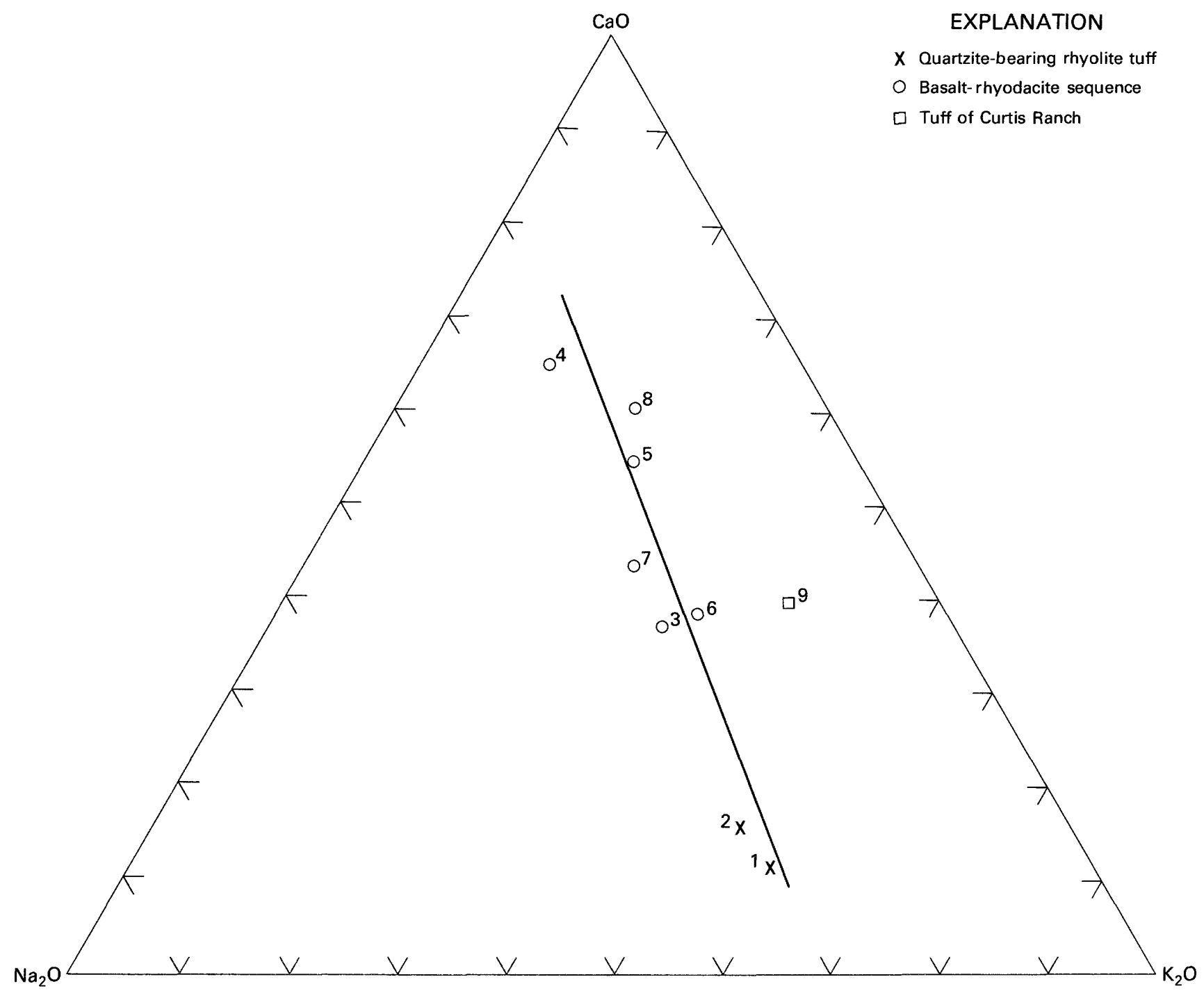

Figure 8.-Ternary diagram showing relation of the $\mathrm{CaO}, \mathrm{Na}_{2} \mathrm{O}$, and $\mathrm{K}_{2} \mathrm{O}$ in rocks from the Challis Volcanics. Sample numbers correspond to those used in table I. Line shows average linear trend formed by alkalies in Challis Volcanics except the tuff of Curtis Ranch.

of similar composition but from different areas show no such linear arrangement. Thus, the linear relations among the various oxides (figs. 8 and 9) support the thesis that these rocks all came from the same parent magma.

The chemical system used in this paper is from Rittmann (1952). According to his classification, sample 3 would be rhyodacite, sample 4 olivine-andesine trachybasalt, sample 5 olivine latite, and samples 6,7 , and 8 dark quartz latite. As the analyzed rocks are fairly representative of the rocks of the area, they probably come close to covering the extremes of composition expected in this sequence.

\section{TUFF OF CURTIS RANCH}

The tuff of Curtis Ranch overlies the basalt-rhyodacite sequence and is overlain by the flow-breccia unit (fig. 4). The tuff occurs in only two outcrop bands: One is 1.5 miles long, south of the Curtis Ranch house near the junction of Frying Pan and Trail Creeks near the east edge of the district, and the other is 2.5 miles long, trending south from Agency Creek to upper Cow Creek, in the north-central part of the district (pl. 1). The northern part of the eastern outcrop band is cut out by a branch of the Lemhi Pass fault, but at least 1,200 feet of tuff is exposed here. In the north-central outcrop band the entire unit is present, but it is somewhat thinner. Here a complete section starting 1,200 feet south of the mouth of Sharkey Creek is 1,200 feet thick. About 1 mile south of this section the tuff has thinned to 400 feet.

The greater part of this unit is made up of light-colored fine-grained crystal-vitric or vitric-crystal tuff. The tuff is generally white or greenish white, although some is a light gray or tan. Rock fragments and crystal fragments are 
TABLE 1.-Chemical analyses and normative compositions of rocks from the Challis Volcanics

[n.d.. not determined; leaders (...). none]

\begin{tabular}{|c|c|c|c|c|c|c|c|c|c|}
\hline \multirow{2}{*}{$\begin{array}{l}\text { Constituent } \\
\text { or mineral }\end{array}$} & \multicolumn{9}{|c|}{ Samples } \\
\hline & 1 & 22 & 13 & 14 & 15 & $=6$ & 27 & 28 & 29 \\
\hline \multicolumn{10}{|c|}{ Chemical analyses (weight percent) } \\
\hline $\mathrm{SiO}_{2} \ldots \ldots \ldots \ldots$ & 74.62 & 73.1 & 59.14 & 48.15 & 51.38 & 59.5 & 58.8 & 55.5 & 65.8 \\
\hline $\begin{array}{ll}\mathrm{Al} \\
\mathrm{Al} & \mathrm{O}\end{array} ; \ldots \ldots . . . .$. & 12.40 & 13.4 & 16.66 & 11.35 & 10.79 & 13.4 & 13.9 & 14.8 & 13.5 \\
\hline $\begin{array}{l}\mathrm{Fe}_{2} \mathrm{O}_{3} \\
\mathrm{FeO}\end{array}$ & .77 & .88 & 7.41 & 2.72 & 2.15 & 4.9 & 6.9 & 6.8 & 2.00 \\
\hline 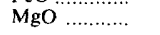 & .29 & 40 & .66 & 14.46 & 14.46 & 3.3 & 1.9 & 4.6 & 1.4 \\
\hline $\mathrm{CaO} \ldots \ldots \ldots \ldots$ &., 84 & 1.4 & 4.20 & 7.38 & 6.20 & 4.8 & 4.9 & 67 & 2.8 \\
\hline …........ & $\begin{array}{l}2.30 \\
4.66\end{array}$ & $\begin{array}{l}2.6 \\
4.6\end{array}$ & $\begin{array}{l}3.13 \\
4.07\end{array}$ & $\begin{array}{l}2.63 \\
1.36\end{array}$ & 2.99 & $\begin{array}{l}2.8 \\
47\end{array}$ & $\begin{array}{l}2.9 \\
3.5\end{array}$ & 3.1 & 3.36 \\
\hline$\cdots \ldots \ldots$ & 1.47 & 1.4 & 4.87 & 3.12 & 1.36 & 1.6 & 1.8 & 1.7 & 6.1 \\
\hline$\ldots \ldots \ldots$ & & 90 & 1.90 & .73 & .62 & 1.1 & 1.8 & 1.9 & \\
\hline $\mathrm{TiO}_{2} \ldots \ldots \ldots . .$. & .10 & .22 & .99 & .78 & .74 & .96 & 1.0 & .75 & 27 \\
\hline Mno & .03 & .10 & .42 & .35 & .35 & .49 & .37 & .23 & .15 \\
\hline $\mathrm{CO}$ & .00 & .02 & .00 & .11 & .11 & .04 & .02 & .05 & .01 \\
\hline …............. & 01 & n.d. & .02 & .01 & .01 & n.d & n.d & n.d. & n.d. \\
\hline $\mathrm{F} \ldots \ldots \ldots \ldots \ldots$ & .07 & n.d. & .09 & .13 & .09 & n.d. & n.d. & n.d. & n.d. \\
\hline Subtotal & 99.70 & & 99.82 & 99.66 & 99.76 & & & & \\
\hline Total & & & & & & & & & \\
\hline \multicolumn{9}{|c|}{ Normative compositions (weight percent) } & \\
\hline Quart & 42.84 & 37.38 & 17.10 & & & 1404 & 190 & 11 & $\overline{44}, 58$ \\
\hline 0 & 28.36 & $\because 1$. & 1,10 & 8.34 & 18. & 14. & & & 21.68 \\
\hline & 20.44 & 23. & 25.1 & & 17. & 24 & & 22.01 & 8.91 \\
\hline$A_{1}$ & 3.89 & & 18. & 15.85 & ii. & 10. & & 20.57 & 14.46 \\
\hline Hvpersthene & .70 & 1.10 & 1.70 & 8.78 & 1913 & 4.80 & 2.50 & 7.30 & 3.00 \\
\hline Oli & ...... & & $\cdots$ & 21.71 & 13. & & & & \\
\hline & & & $\cdots$ & 14. & & 7.99 & 5.40 & & \\
\hline $\mathrm{M}$ & .93 & & & 4.18 & 3.25 & (1.87 & & & .70 \\
\hline $\begin{array}{l}\text { Hematite ..... } \\
\text { llmenite ........ }\end{array}$ & $\begin{array}{l}.16 \\
.15\end{array}$ & $\begin{array}{l}.96 \\
15\end{array}$ & $\begin{array}{r}7.68 \\
46\end{array}$ & 103 & 1.52 & $\begin{array}{l}1.60 \\
1.98\end{array}$ & 6.24 & $\begin{array}{l}4.32 \\
152\end{array}$ & 1.76 \\
\hline Rut & & & & $\ldots \ldots$ & $\ldots \ldots$. & $\ldots \ldots$. & $\ldots . .$. & $\ldots . .$. & \\
\hline Corundum .. & $2.2 \ddot{4}$ & 1.63 & (1) & $\cdots$ & & ...... & $\cdots \cdot \cdot$ & ...... & 3.57 \\
\hline & & .34 & 1.01 & 1.04 & 1.01 & 1.34 & 1.01 & .34 & .34 \\
\hline $\begin{array}{l}\text { Calcite .............. } \\
\text { Fluorite }\end{array}$ & .07 & $\cdots .$. & .ii & .20 & .20 & .10 & $\ldots .$. & .20 & .... \\
\hline Total & 99.78 & 99.81 & 100.09 & 100.12 & 99.11 & 100.00 & 100.00 & 100.04 & $\overline{99.61}$ \\
\hline
\end{tabular}

'Standard rock analysis by Edythe E. Engelman, U.S. Geological Survey laboratory, Denver. Colo.

Rapid rock analysis by Lowell Artis, U.S. Geological Survey laboratory, Washington, D.C. Sample descriptions:

1. Quartzite-bearıng rhyolite tuff from peak 7,636 on Continental Divide, I mile south of Lemhi Pass.

Quartzite-bearing rhyolite tuff from north side of road along Agency Creek north of mouth of White Creek.

3. Rhyodacite from just east of Trapper Creek in NE1/4 SE $1 / 4$ sec. 23, T. $10 \mathrm{~S}$., R. $15 \mathrm{~W}$

Olivine-andesine trachybasalt from low ridge between Trapper and Bear Creeks in SW $1 / 4 \mathrm{SW}^{1 / 4} \mathrm{sec}$ 26. T. 10 S., R. $15 \mathrm{~W}$

5. Olivine latite from knoll just north of Trapper Creek in SE1/4 NW1/4 sec. 34, T. 10 S.. R. 15 W Dark yuartz latite from just north of road along Agency Creek, 3,000 teet southwest of mouth of Flume Creek.

7. Dark latite trom just north of road along Agency Creek, 200 teet southwest of mouth of Sharkey Creek.

8. Dark quartz latite adjacent to road along west sıde of Yearlan Creek in SW1/4NW1/4 sec. 36, T. 18 N., R. 24 E.

9. Crystal tuff from north side of road cut along Agency Creek, 3,700 teet northeast ot mouth of Sharkey Creek

variable in amount and each may range from as little as a few percent to as much as 70 percent. Commonly they each make up 20-50 percent of the tuff. Rock fragments are principally of volcanic material and generally of glass. In the eastern part of the area pumice is the most abundant clast. Other volcanic rock pieces are fine grained; a few have small plagioclase phenocrysts. Crystal fragments are principally quartz and plagioclase, although in some places abundant sanidine is found. Biotite in amounts as much as 2 percent is almost universally present. Minor amounts of hornblende, sphene, zircon, and magnetite are present in some specimens. The matrix is an ash (glass) that commonly contains glass shards and in a few places small microlites. In some places the ash has small vesicles; some of these are filled with tridymite. The tuff is generally fairly compacted and in a few places it is welded. Porcelanite was found in one bed in the eastern outcrop band on the northwest side of Frying Pan Creek.

The upper and lower parts of the tuff of Curtis Ranch differ in the area south of Agency Creek. Here the lower 100 feet of this unit is sorted and consists of layers 0.25-2 inches thick. Some layers may consist mainly of vitric fragments, other of crystal clasts. Grains within the layers are also commonly sorted as to size and the average grain size of one layer may be $0.002 \mathrm{in}$. and that of an adjacent layer $0.016 \mathrm{in}$. These tuffaceous rocks are probably water laid. The upper part of the tuff of Curtis Ranch in this same general area consists of a volcanic conglomerate overlain by a volcanic sandstone. The tuffaceous conglomerate is poorly exposed and irregular in thickness; in places it may be as much as 150 feet thick. Near its southern exposure this rock consists of rounded to subrounded pebbles and cobbles of Precambrian quartzite set in a matrix of tuff. Farther north the larger fragments are mainly of medium- to dark-brown aphanitic volcanic rock. In places this rock grades into a breccia. On the south side of Sharkey Creek a volcanic sandstone is found overlying the tuffaceous conglomerate. The sandstone is fairly well sorted and its grains are rounded to subrounded having an average diameter of $0.023 \mathrm{in}$. They are similar in composition to the clasts found in the tuff, having both large crystal and vitric components. Crystals are chiefly plagioclase, sanidine, and quartz, but minor biotite is conspicuous. Vitric fragments are mainly devitrified glass, including pumice and an aphanitic volcanic rock. A few grains of quartzite are also present. The matrix consists of a minor amount of ash.

A chemical analysis was made of a crystal tuff containing some 30 percent crystal fragments. It was collected on the north side of Agency Creek (table 1, no. 9). If this rock was classified on its chemical composition according to Rittmann (1952), it would be a quartz latite. A comparison of this sample's normative composition with that of the two samples of quartzite-bearing rhyolite tuff (table 1, nos. 1 and 2) shows that the tuff of Curtis Ranch has less orthoclase and albite and more anorthite and hypersthene. A comparison of the alkalies to one another and of $\mathrm{MgO}$ to total iron oxide of this rock with other analyzed rocks is shown in figures 8 and 9. Compositionally this rock appears unrelated either to rocks of the basalt-rhyodacite sequence or to those of the quartzite-bearing rhyolite tuff, and was probably derived from another source.

\section{FLOW-BRECCIA UNIT}

The flow-breccia unit overlies the tuff of Curtis Ranch (fig. 4) in a relatively small area east of Cow Creek and south of Agency Creek. This unit can be traced in a north-south direction for about 2 miles. The upper part of this unit is cut 


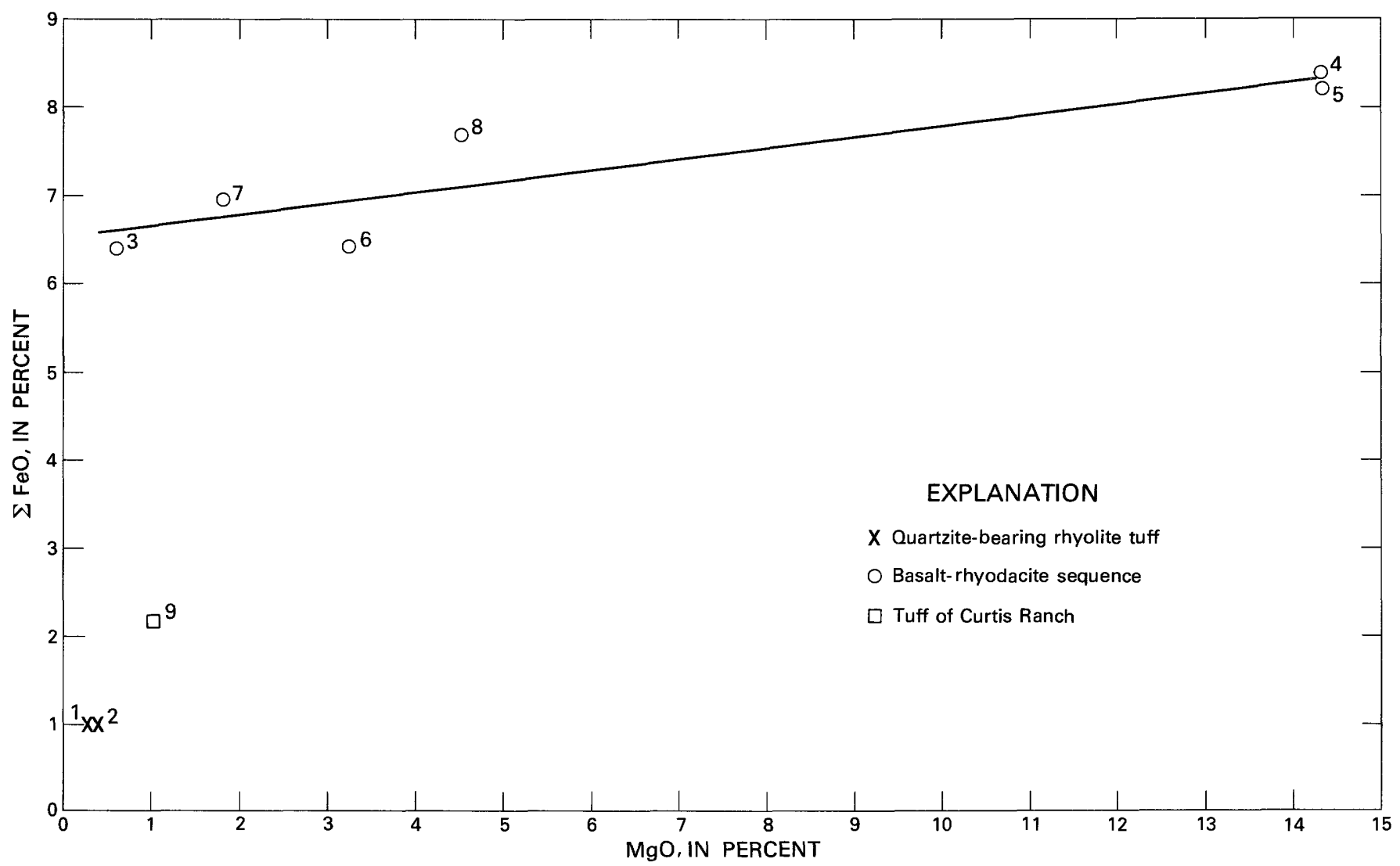

Figure 9.--Graph showing relation of MgO to total iron oxide in some rocks from the Challis Volcanics. Sample numbers correspond to those used in table 1. Line shows average linear trend formed by total iron oxide to magnesium oxide ratio in rocks of the basalt-rhyodacite sequence.

out by the fault that bounds the southeast and east sides of the Challis Volcanics. Exposures of this unit are also limited by a cover of older glacial deposits. The flow-breccia unit between White and Sharkey Creeks has a minimum exposed thickness of 580 feet.

The exposed part of this unit consists principally of flow breccia but also includes some dark flow rocks. Flow rocks are probably more common than they appear to be, as they are not as resistant to weathering as the breccias and thus are not as well exposed. Flow breccias are made up of angular to subrounded pieces of flow rocks in a similar matrix. Fragments are 0.06 inch to several feet in diameter of greenish-gray and light- to dark-brown rocks that are commonly weathered limonitic brown. Individual flow-breccia units range from several to about 40 feet thick. Flow breccias are also common in certain parts of the basalt-rhyodacite sequence. The two units are primarily distinguished by the presence of the intervening tuff of Curtis Ranch.

\section{QUARTZ LATITE}

Light-colored quartz latite intrusives and flows occur in small areas scattered over the northeast corner of the district.
A small pink dike (too small to show on plate 1) cuts the conglomerate of Flume Creek along the north side of the Agency Creek road, 2,500 feet west of the mouth of Flume Creek. The relations of the quartz latite to the volcanic rocks are not exposed in other areas. A circular body of quartz latite that is probably an intrusive occupies a small area about 0.33 mile west of Lemhi Pass. Other outcrops of quartz latite occur near Sheser Creek in the northeast corner of the district. Many of these outcrops have a well-developed flow structure and for the most part are flows. The lack of more definite data precludes determining either the number or the relative ages of most parts of the quartz latite unit.

The quartz latites are generally pink to purplish brown, although some are light gray and brown. They are porphyritic rocks containing 10-20 percent phenocrysts 0.04-0.08 in. in diameter that are set in a matrix of tiny crystals and glass. Their principal phenocrysts are quartz and plagioclase but they also contain small amounts of potassium feldspar and biotite. In the quartz latite west of Lemhi Pass a little altered hornblende was also noted. In the matrix tiny crystals of plagioclase, quartz, potassium feldspar, and biotite are set in a devitrified glass. Staining of several quartz latite specimens with sodium cobaltinitrite 
identified the potassium fledspar among the small crystals as well as indicating that considerable potassium occurred in the glass. These rocks were classified as quartz latite on the basis of their abundant quartz and plagioclase phenocrysts along with positive qualitative tests for potassium.

\section{YOINGER BASALT}

The younger basalt is found in three small areas, none larger than 0.25 square mile in size, in the northeastern part of the district between Trail and Bear Creeks (pl. 1). This rock unconformably overlies rocks of the basalt-rhyodacite sequence in all three areas, and in addition the east edge of the basalt that lies astride of Trail Creek overlaps the tuff of Curtis Ranch. The younger basalt closely resembles some of the flow rocks and flow breccias in the basalt-rhyodacite sequence but is separated from them by an angular unconformity. The younger basalt in the northernmost outcrop area strikes east and dips $15^{\circ} \mathrm{S}$., but a flow breccia in the adjoining basalt-rhyodacite sequence strikes north and dips $80^{\circ} \mathrm{E}$. The younger basalt in the central area also strikes east, but dips only $5^{\circ} \mathrm{S}$.; those in the southernmost area are almost horizontal. Rocks of the basalt-rhyodacite sequence adjacent to these two areas have a northerly strike and $\operatorname{dip} 30^{\circ}-55^{\circ} \mathrm{E}$.

The younger basalt was once more extensive than at present, and the three outcrop areas represent small remnants of a much larger, thicker unit. The northern two areas are preserved because they are capped by a resistant flow breccia and the southern one because it was deposited in a topographic hollow in the underlying basalt-rhyoacite sequence. The younger basalt ranges in thickness from 50 to 400 feet.

The younger basalt is made up of flows and interlayered flow breccias. The flows are gray or brown aphanitic basalts, and some contain olivine phenocrysts. The fragments in the flow breccias are composed of similar material. These clasts are angular to subrounded and 0.1-8 inches across. The matrix is similar to the fragments. The flow breccia occurs in discontinuous layers that are 20-50 feet thick. Although the breccias are composed of material similar to the flows, they are more resistant to weathering and form prominent outcrops that cap the more poorly exposed flows.

\section{SANIDINE-QUARTZ WELDED TUFF}

The sanidine-quartz welded tuff occurs in scattered patches in the central part of the district (pl. 1). Most of it is found in the vicinity of Ghoul Basin, although it occurs as far south as Yearian Creek Valley. This unit is one of the younger units of the Challis Volcanics, and in various places it unconformably overlies rocks of the basalt-rhyodacite sequence and quartzite-bearing rhyolite tuff. It is offset by several large faults, including the Dan Patch and Lemhi Pass faults, but this unit in part overlies some of these faults and is not offset as much as the other units. The smaller amount of movement on the sanidine-quartz welded tuff can be accounted for by this rock being deposited after some but not all the movement had occurred along the faults. The age of this unit relative to the quartz latite or the younger basalt is not known.

The sanidine-quartz welded tuff is a white, tan, or light-brown hard welded tuff containing a few to 20 percent crystal clasts set in a fine-grained dense matrix. Most of the crystal fragments range in size from 0.004 to $0.060 \mathrm{in}$. although in a few localities in addition to these crystal fragments, smaller ones occur in the matrix. Sanidine and quartz are the principal and in some localities the only crystal fragments noted. Plagioclase was noted in several places, as well as minor amounts of biotite. A few small glass fragments of material similar to the matrix occur locally. The matrix is a partly devitrified glass - an ash-that commonly contains abundant glass shards. Staining indicates that the matrix contains at least moderate amounts of potassium. Compositionally this rock is probably rhyolite.

\section{AGE}

The Challis Volcanics are probably mainly of Eocene age, although their range within the Tertiary is not fully known. They generally overlie much older rocks, and are overlain by younger Tertiary rocks. In the Lemhi Pass area the Challis overlies Precambrian Y rocks, but farther south in the Leadore quadrangle it also overlies Kinnikinic Quartzite (Ordovician), Saturday Mountain Formation (Ordovician), and Jefferson Dolomite (Devonian) (Ruppel, 1968). The Challis is overlain by the tuffaceous sedimentary rocks, a sequence of lacustrine volcanic sediments containing plant and vertebrate fossils the ages of which indicate that these tuffaceous rocks were deposited in some part or all of a time between late Eocene and middle Miocene.

The Challis Volcanics have been dated in one place within the Lemhi Pass thorium district. A specimen of crystal tuff was collected along Agency Creek on the north side of the road about 3,500 feet northeast of the mouth of Sharkey Creek in the NW $1 / 4 \mathrm{SW}^{1 / 4} / 4$ sec. 19, T. 19 N., R. 25 E. Age determinations by the potassium-argon (K-Ar) method on both biotite and sanidine were made by R. F. Marvin, H. H. Mehnert, and Violet Merritt in the U.S. Geological Survey's age laboratory in Denver, Colo. The determined age of the biotite is $42.3 \pm 1.4$ million years (m.y.); that of the sanidine is $40.3 \pm 1.4 \mathrm{~m} . \mathrm{y}$. The average age of the two determinations is 41.3 m.y. The specimen was collected from near the center of the tuff of Curtis Ranch, and is therefore near the top of the Challis Volcanics exposed in the Lemhi Pass thorium area. Ages reported from other areas are older, perhaps because the other samples were taken from lower in the sequence or because the Challis Volcanics were deposited in other areas at a somewhat earlier time. A sample of biotite quartz latite taken from the Germer Tuffaceous Member along U.S. 
Route 93, 4 miles south of Salmon, was dated at 45.5 m.y. by the K-Ar method (Axelrod, 1966, p. 497-498). Five samples collected within 17 miles of the town of Challis from various rock types within the Challis Volcanics had ages that ranged from 43.8 to 49.0 m.y. by the K-Ar method (Armstrong,1974, p. 12). These ages suggest that the Challis was deposited over much of Eocene time. Although data are presently lacking, the Challis may have been deposited as early as Paleocene.

\section{TERTIARY TUFFACEOUS SEDIMENTARY ROCKS}

The tuffaceous sedimentary rocks were deposited in topographic basins in mid-Teritary time after the last period of large-scale deformation. These rocks are widespread along the lower flanks of the Lemhi and Salmon Valleys to the north and west of the district and on Horse Prairie (the area between the Beaverhead Mountains and the Tendoy Range to the east). Within the thorium district they also occupy the basin along Cow and Yearian Creeks. They are thickest in the deeper part of the basins, and at the lower end of the Lemhi Valley near the town of Salmon the minimum thickness of these rocks is estimated to be 1,500 feet, and they may be several times as thick. The rocks thin up this valley, and 18 miles southeast, where the valley crosses the northwest corner of the Lemhi Pass thorium district, only a few hundred feet of this unit are found.

The tuffaceous sedimentary rocks, because they had a dominant volcanic component, were of early Tertiary age, and occurred in south-central Idaho, were originally considered to be part of the Challis Volcanics (Ross, 1934, p. 46). The two were separated into two formations by Anderson (1956, p. 31) on the basis of differences in lithology and by the presence of an angular unconformity between them. Ross in 1962 (p. 74-75, 88-91) still believed that little basis existed for separating the tuffaceous sedimentary rocks from the Challis Volcanics. His reasons basically are as follows: (1) Anderson (1956, p. 89) stated in his description of the Salmon quadrangle that the sedimentary rocks contain no products of direct volcanic origin, such as flows, welded tuffs, or tuffs, whereas they obviously do, (2) as most tuffaceous units in the Challis Volcanics are more or less water sorted, they would be difficult to distinguish from sedimentary rocks derived by erosion from volcanic rocks, and (3) Anderson's evidence for unconformities between the two rock types is not convincing. Anderson divided the tuffaceous sedimentary rocks into several units, but large differences occur in his descriptions and in the names he used for the various units $(1956$, p. $28-31 ; 1957$, p. 16-19; 1959, p. 25-28; 1961b, p. 31-35) in the Salmon, Baker, North Fork, and Lemhi quadrangles. Furthermore, there are major inconsistencies in his mapping both within and between quadrangles. For instance, he traced the tuffaceous sedimentary rocks in the northern part of the Lemhi quadrangle directly into the Challis Volcanics in the southern part of the Baker quadrangle. Although Anderson (1956, p. 89) noted that the sedimentary rocks in the Salmon quadrangle contained no products of direct volcanic origin, in his later studies $(1957$, p. $16 ; 1959$, p. $26 ; 1961$ b, p. 32$)$ he noted the presence of tuff, tuffaceous materials, and even welded tuff in the Baker, North Fork, and Lemhi quadrangles. He (1957, p. 18) also reported widespread occurrence of bentonite, which he presumed was derived from volcanic ash. Ross (1962) noted the difficulty in distinguishing the two water-laid units, yet at only a few places in the Lemhi Pass area, such as the base of the tuff of Curtis Ranch, is there any evidence that any of the tuff in the Challis is water laid. As noted by Ross, inconsistencies of mapping between areas and also within areas are large, but they do not invalidate the observation that the Challis is separated from the tuffaceous sedimentary rocks by an angular unconformity. Anderson (1956, p. 31 and pl. 5-B) even indicates where the unconformity between the two units may be seen. This unconformity is also apparent in several places in the Lemhi Pass the -ium district. One example is found in the northwest corner of the district (pl. 1) where the quartzite-bearing rhyolite tuff of the Challis Volcanics strikes N. $25^{\circ}$ E. and dips $42^{\circ} \mathrm{NW}$. and tuffaceous sedimentary rocks due west strike N. $76^{\circ}$ E. and dip $45^{\circ}$ SE. J ust south of Pattee Creek, conglomerate in the basal part of the tuffaceous sedimentary rocks can be seen irregularly overlying the Challis Volcanics.

As noted above Anderson has divided the tuffaceous sedimentary rocks into several units. In both the Baker and Lemhi quadrangles he has a threefold division (1957, p. $16-19 ; 1961$ b, p. 69-71). In the Lemhi quadrangle his three units are called the Kenney, Geertson, and Kirtley Formations. All three are shown on his map in the vicinity of Pattee Creek, and two - the Kenney and the Geertson Formations - are shown in the Cow Creek-Yearian Creek basin. In both areas the contacts separating the units are unrealistic, as in places they cut across the strike of the beds. The units, as mapped, also include flow rocks of the Challis Volcanics and some Precambrian rocks. Exposures in the Cow Creek-Yearian Creek area consist of only a few small widely scattered outcrops in an area noted for its large landslides. Furthermore, neither Anderson's descriptions of the rock units nor the rocks as mapped in the field furnish any evidence for dividing those rocks into three formations. Hence, the general name tuffaceous sedimentary rocks is used in this paper for the relatively thin part of a much thicker and better exposed unit to the northwest.

\section{DESCRIPTION}

The tuffaceous sedimentary rocks consist mainly of fine-grained tuffaceous clastic rocks but have some layers and lenses of conglomerate. The finer grained sedimentary rocks range from fine-grained sandstone to shale. In some layers, where the vitric fragments predominate, the rocks are tuff. In places, thin layers of sandstone are interlayered with those of shale, tuff, or silt. These individual layers are thin (fig. 10), the sediment is well sorted, and in a few places 


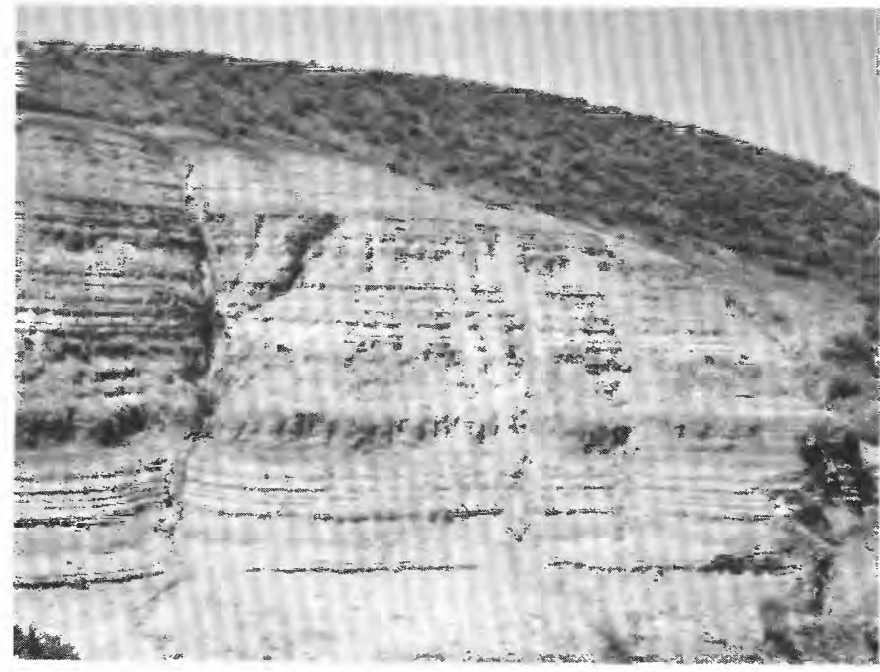

Figure 10.- Thin-bedded tuffaceous sedimentary rocks exposed in low hills northeast of mouth of Agency Creek.

graded bedding is present. The sorting in these rocks indicates that they are water laid. The tuffaceous rocks in this unit differ from those in the Challis Volcanics not only in being better sorted but the grains may be rounded, the layers are commonly fissile, and the many layers of the rocks have a high bentonite content. The bentonite beds can be distinguished on an exposed surface by an intricate pattern of shrinkage cracks around small circular clots of clay or they can readily be distinguished by their stickiness and slipperiness when wet. Most of these beds are white or light gray but some are tan or brown. Beds range from a fraction of an inch to a few feet in thickness (fig. 10), and in some places, such as north of Pattee Creek and in the upper reaches of Cow Creek, they commonly split into paper-thin layers. These sedimentary rocks are made up of detrital material from the surrounding area, principally from the easily eroded Challis Volcanics. These fine-grained rocks weather quickly owing to their friable nature and high clay content, and even in roadcuts, exposures are rare unless they are freshly made. Most exposures occur in areas of active erosion as along streams.

Sandstones and siltstones consist mainly of crystal fragments; they may also have a large component of subrounded to rounded rock fragments. Most also contain a small amount of glass clasts. Crystal fragments are chiefly quartz. Many rocks have a moderate content of sanidine and plagioclase. In places most or some of the feldspar has been altered to sericite. Other minerals noted in minor amounts include biotite, hornblende, chlorite, tourmaline, and zircon. Rock fragments consist of Precambrian Y quartzite or siltite and of light to dark brown aphanitic volcanic rocks.

Tuff layers are fairly common and may be entirely made up of fine particles of ash, or they may have an intermixture of air-laid or water-laid crystal and rock fragments with the ash. Much of the ash has been altered to clay.
Conglomerates are interlayered with the finer grained sedimentary rocks. They are most common in the northwest part of the district on either side of Pattee Creek. Although exposures of conglomerates are spotty, they are much better exposed than the fine-grained rocks. The conglomerate consists of subrounded to rounded pebbles and cobbles set in a sand matrix. Most of the pebbles or cobbles are 0.25-6 in. in diameter, although a layer exposed along a road 0.75 mile east of Yearian Creek has boulders as large as 2 feet across. The clasts may be light- to medium-gray fine-grained quartzite of Precambrian age; they may be red, brown, or black flow rocks of the Challis Volcanics; or they may be, as they commonly are, a mixture of the two principal rock types. Sand grains that fill the interstices and form small lenses or discontinuous layers consist of quartzite and flow-rock clasts plus crystal fragments. The latter are mainly quartz, but sanidine and plagioclase are generally present. Small amounts of vitric fragments may be found in the matrix. These conglomerate layers are similar in appearance to two conglomeratic units in the Challis Volcanics: The basal conglomerate and the conglomerate of Flume Creek. They may also resemble the Beaverhead Formation of Late Cretaceous, Paleocene, and Eocene age.

AGE

The age of the tuffaceous sedimentary rocks in the Lemhi Pass thorium district could range from late Eocene to Pliocene, although the time range of this unit is not fully known. These sediments overlie the Challis Volcanics, from which an age of $41.3 \mathrm{~m}$.y. was determined by the $\mathrm{K}-\mathrm{Ar}$ method on a tuff near the top of the formation. The sedimentary rocks are overlain by the older glacial deposits of Quaternary age.

Two fossil collections, one of plants and the other of vertebrates, have been made in and near the thorium district. The plant collection was made from two nearby places. One locality is in a roadcut 0.6 mile south of the junction of Cow Creek with a tributary that parallels the road in the $\mathrm{NE}^{1 / 4} \mathrm{SE}^{1 / 4}$ sec. 1 , T. $18 \mathrm{~N}$., R. $24 \mathrm{E}$. The other locality is about 800 feet north of the first locality and is on a barren hillside above the road and below a small prospect pit. Abundant plant remains and the tail of a fish were collected here. The following plants were identified by Jack A. Wolfe:

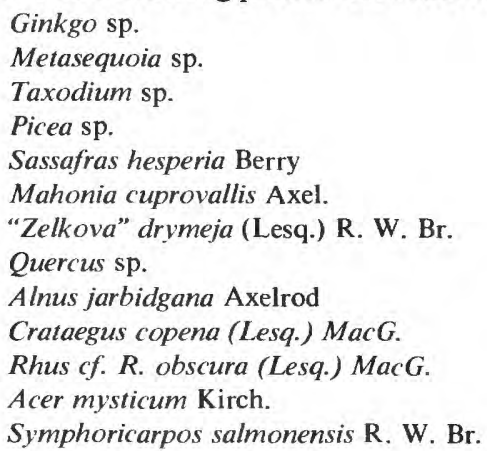

Wolfe (written commun., 1974) notes that the alder, Alnus 
jarbidgana, is the most abundant plant in the collections, and that several species, including this one, are present in collections made in tuffaceous sedimentary rocks near Salmon, Idaho. He states that the oldest possible age of these collections is late Eocene, as this is the age of oldest known occurrences of "Zelkova" drymeja, Almus jarbidgana, Mahonia cuprovallis, and Acer mysticum. The upper limit of this assemblage of plants is not as well known, but it does not extend into the Miocene.

The fish tail was examined by David H. Dunkle (written commun., 1973), who states that the scale characteristics, extended dorsal fin, and caudal fin structure are similar to that of the aberrant sucker, Amyzon. This genus has previously been found in sedimentary rocks that range in age from Eocene to middle Miocene.

Several vertebrate collections have been made in a small area about 1.5 miles south of the southeast corner of the area on the east side of Peterson Creek near its mouth (Anderson, 1961b, p. 33-34). Some of the fossils collected by Ralph Nichols and identified by C. L. Gazin are rhinoceros teeth, Parahippus sp., Mylagaulus sp., and Merychyus (Ross, 1962, p. 101). Other specimens collected and identified by J. A. Wilson are Promerychocherus sp., Ticholeptus sp., Parahippus sp., and Alticamelus sp. Wilson (1946, p. 1262) considered the fauna to be somewhere between early Miocene and early Pliocene in age. G. E. Lewis, in summarizing previous work in 1961 (written commun.), stated that this vertebrate collection is from a stratigraphic position that is considered to represent either the top of the lower Miocene or the bottom of the middle Miocene in North American continental stratigraphy (Ross, 1962, p. 101). The sedimentary rocks on Cow creek, from which the plants came, are most likely Oligocene; those on Peterson Creek, from which the vertebrates came, are Miocene. The plant-bearing rocks are lacustrine; those containing the vertebrate fossils are continental and may represent a Miocene fan. Sedimentary rocks of this type are fairly common along the Lemhi valley southeast of the area mapped, but are uncommon within the thorium district.

\section{TERTIARY DIORITE}

Diorite occurs widely scattered in many thin dikes and several small irregular bodies. Although diorite dikes are found in many parts of the district, most are concentrated in a 9-mile-long northwestward-trending zone some 4 miles broad that extends from the headwaters of Everson Creek on the east margin of the district to the headwaters of Agency Creek. Some diorite bodies occur in adjacent areas. One diorite body is found about a mile south of the Lemhi Pass thorium district on Cedar Gulch in the Goat Mountain quadrangle (Staatz, 1973), and another is found 9 miles north of the area in the Baker quadrangle (Anderson, 1957, pl. 1).

The diorite is generally poorly exposed, and it is principal- ly found on ridges and in prospect pits. Six of the dikes seen in this area are exposed only in trenches or underground workings. Scattered pieces of diorite float on some of the mountainsides indicate that many poorly exposed dikes were not located. Some of the diorite, however, forms prominent outcrops. Two such well-exposed bodies are the long dike that lies east of Bear Creek near the Dan Patch veins (loc. 98) and the irregular body on the east slope of the Cow Creek basin in the SW1/4 sec. 32, T. 19 N., R. 25 E. Much of the diorite is partly altered, which may account for the lack of outcrops in many areas.

Most of the diorite bodies are dikes. The dikes have various attitudes, but mainly they have a general westerly strike which ranges from N. $45^{\circ}$ W. to S. $45^{\circ}$ W. Dips are in any direction, but are generally steep. The attitudes of dikes and thorium veins that are adjacent to one another, such as those on the Brown Bear No. 2(loc. 78) property, Dan Patch (loc. 98), G\&G (loc. 89), and Wonder (loc. 45), are commonly similar, indicating that both probably occupy the same sets of fractures. The presence of diorite dikes in trenches near or adjacent to those containing thorium veins in the northwest end of the zone that contains most of the dikes, originally led to the belief that the two were approximately syngenetic. Further mapping did not support this assumption, and the association of the two is in part because both occur in the same joint sets and in part because trenching has afforded better exposures. In size the dikes range from one with an exposed length of 20 feet and a width of 1 foot to one having a known length of 6,500 feet and a maximum width of 150 feet. The largest dike, which is on the east side of Bear Creek, ranges in thickness from 3 to 150 feet.

In addition to the dikes there are two small irregular diorite intrusives. One, which has a generally triangular shape, occurs on the east side of the Cow Creek drainage in the SW $1 / 4$ sec. 32 , T. 19 N., R. 25 E. This intrusive is 1,150 feet long and has a maximum exposed width of 550 feet. The other intrusive lies on the southwest side of the Bull Moose fault along the east edge of the area. This intrusive is $700 \mathrm{feet}$ long and has a maximum width of 500 feet. From the main part of this intrusive a dike extends southeastward along the fault. The diorite varies in color from medium gray to black; many intrusives are dark gray, greenish gray, drab olive green, or speckled. The diorite tends to be fine to medium grained and locally porphyritic. Equigranular rocks have an average grain size of 0.003 to 0.05 in. Porphyritic rocks have phenocrysts $0.08-0.16$ in. across set in a matrix of 0.004 to 0.012 in. grains. In general the larger dikes tend to be coarser grained and are more likely to be porphyritic.

These rocks are made up principally of plagioclase and mafic minerals. They contain $30-75$ percent plagioclase and 22-70 percent mafic minerals. All would be classified as diorite according to Grout (1932, p. 50). Plagioclase, which is generally andesine, occurs in anhedral to subhedral crystals that are commonly zoned. Other leucocratic 
minerals include orthoclase and qaurtz. Both are found as small inconspicuous grains interstitial to other minerals. Where present orthoclase makes up less than 1-6 percent of the rock and quartz less than 1-3 percent.

The mineral content of the diorite, especially the mafic minerals, shows considerable variation. The mafic minerals vary not only in amount but also in kind. The principal mafic minerals are augite, hornblende, biotite, and chlorite. Not all of them occur in every specimen of diorite. Augite (3-30 percent) and hornblende (0-30 percent) are generally the most abundant but any one of the four may be most abundant in any particular rock. Biotite, which is the least common of these four minerals, is the principal mafic mineral in a few places. In a dike just north of Pattee Creek in the northwest corner of the area, and in another dike that is adjacent to the north side of the Wonder vein (loc. 45), it makes up 40 and 35 percent, respectively, of the dikes, Augite forms stubby subhedral crystals; hornblende occurs as long dark-brown to green lathlike crystals; biotite forms irregular brown to green plates; and chlorite was found as small pale-green irregular crystals. Chlorite, which is an alteration product of the other three minerals, commonly forms rings around augite phenocrysts in the porphyritic diorite. Accessory mafic minerals include apatite, hematite, and magnetite. In addition, epidote, sericite, and calcite form during the alteration of the other minerals.

The diorite was probably intruded during middle Tertiary time after most of the Challis Volcanics were deposited, but before the emplacement of the veins. Dating these dikes is difficult, as the diorite intrudes only the Precambrian rocks. Diorite does not intrude the Challis Volcanics and might be presumed to be older. The lack of diorite intrusives in the volcanics, however, may be due either to the intrusions being older than the volcanic rocks or to the lack of fractures in the volcanics along which the diorite could be intruded. An answer to this problem can be found near the east edge of the area just north of the North Fork of Everson Creek, where a small diorite intrusion has a dike extending from it along the Bull Moose fault. The dike is thus younger than the fault, and as the fault offsets the Challis Volcanics, it must also be younger than those volcanic rocks. Diorite is older than either the copper or the thorium veins. This relation is best shown in the underground workings of the Copper Queen mine (loc. 43), where both Schipper (1955, p. 29) and Sharp and Cavender (1962, p. 52) noted that a copper-bearing quartz vein cuts across several diorite dikes. The dikes are also highly altered and contain sulfides. Crosscutting relations in this same mine indicate that the thorium veins are younger than the copper veins. In addition, the diorite dike that lies adjacent to the thorium vein on the Wonder property (loc. 45) contains a little pyrite, which was probably introduced when the vein was emplaced. These data limit the age of the diorite and indicate that the intrusives formed after the major faulting that cut the Challis Volcanics, but before the veins were emplaced.

\section{QUATERNARY DEPOSITS}

Thick deposits of Quaternary age occur in about one-fifth of the area (pl. 1). These have been divided by composition, form, and origin, into eight unconsolidated units: (1) Older glacial deposits, (2) younger glacial deposits, (3) terrace deposits, (4) alluvial fans, (5) rock glacier, (6) landslide deposits, (7) mudflow, and (8) alluvium. The older glacial deposits are the most widespread and underlie more than half of the area mapped as Quaternary rocks (pl. 1). Actually, they are even more widespread than shown. As the principal interest in this area was in the older consolidated rocks, the glacial deposits are only mapped where the distance between outcrops of the underlying rocks is more than 1,000 feet. The boundaries between the glacial deposits and the consolidated rocks, hence, are approximate. The two types of glacial deposits have different origins: the older glacial deposits are a product of a southward-moving ice lobe, and the younger glacial deposits were formed by small mountain glaciers. The glacial till derived from the two sources is commonly similar, and the two ages of till are separated on the basis of form and occurrence.

\section{OLDER GLACIAL DEPOSITS}

Older glacial deposits at one time covered the entire area. Most of these deposits have since been stripped away by erosion, but where protected in topographic lows or where they were originally quite thick, they still mantle the older rocks. These glacial deposits are abundant in three areas: (1) The northeast corner of the district, where they mantle most of the Sheser Creek basin; (2) the northwest corner of the district, where they cover a series of low rounded ridges; and (3) the drainage basins of Cow and Yearian Creeks, where they principally overlie the Challis Volcanics and the tuffaceous sedimentary rocks. Where the till is thick, it fills in the angular irregularities in the pre-Quaternary topography and gives the landscape a more smoothed out and rounded appearance. The topography in the Sheser Creek basin, which is underlain by older glacial deposits, is much gentler than that directly west along the Continental Divide, which is underlain by Precambrian quartzite. Similarly, the head of Yearian Creek basin, which is underlain by glacial deposits, is gently rolling compared to the steep mountains on either side, which are underlain by Precambrian rocks.

The older glacial deposits consist principally of subangular to subrounded blocks, boulders, cobbles, and pebbles set in a matrix of brown sand, silt, clay, and soil. The clasts are mainly fine- to medium-grained Precambrian quartzite. Pieces of quartzite are generally less than 1 foot across, although blocks as much as 10 feet across occur in a few places. In addition to quartzite a few pieces of siltite and, even more rarely, basalt, rhyodacite, or tuff, occur in the till. The volcanic rock fragments are generally not more than several inches across and occur in till that is on or adjacent to volcanic rock outcrops. The volcanic rocks disintegrate 
fairly easily and probably have not been transported more than a mile. In most places the finer material weathers to a rich brown soil, Grass, flowers, and sage, which commonly grow on it, are bigger and more luxuriant than those found on somewhat leaner soils over consolidated materials. The difference in plant size can be used to mark the boundary accurately between the glacial deposits and the adjoining rock type. In places these glacial deposits are hard to identify, as they become mixed with talus, weathered soil formed on the underlying rocks, and landslide deposits.

In additon to till, a small amount of glacial river gravels are included in this unit. These gravels occur as remnants on hilltops and slopes in a few widely scattered localities. The gravel differs from the till in being made up of well-rounded pebbles, boulders, and cobbles. By far the most common gravel is Precambrian quartzite. In addition, however, exotic rocks, which are not found within many miles of the Lemhi Pass district, may be present. A small patch of gravel on hilltop 7,381 on the north side of Frying Pan Creek in the $\mathrm{NW} 1 / 4$ sec. $22, \mathrm{~T} .10 \mathrm{~S}$., R. $15 \mathrm{~W}$. contains, in addition to Precambrian quartzite, a white quartzite, a coarse-grained quartz monzonite, a coarse-grained quartz diorite, and a biotite-quartz schist. Another patch of gravel at the east end of Ghoul Basin in the E1/2 sec. 8, T. 19 N., R. 25 E. has, besides the Precambrian quartzite, a few pieces of red quartzite, black chert, and a coarse-grained orbicular biotite granite.

The older glacial deposits were formed under a thick icecap that originated north of this district. Although mountain glaciation has been recognized previously here, regional glaciation has not. Anderson (196lb, p. 36-38) described glacial deposits formed during several periods, but believed them all due to mountain glaciation. In places he has mapped a unit called "ridge gravels," which in the mapped area (pl. 1) corresponds in general to the older glacial deposits. That the older glacial deposits were formed by an icecap is supported by the following lines of evidence: (1) The wide distribution of the deposits across both valleys and mountaintops; (2) the large vertical distribution over which the deposits are found-in this area they are found between elevations of 5,200 and 8,160 feet; (3) the direction of movement of glacial material in some places up drainages, rather than consistently down them; and (4) the general direction of movement of rock fragments from the north. Southward movement of volcanic rock fragments can be demonstrated in glacial deposits that lie southwest of the junction of Frying Pan and Trappers Creeks in the northeast part of the area (pl. 1). These deposits contain a few pieces of tuff and rhyodacite, which are unlike any volcanic rocks south of this area but are similar to rocks that lie 1-1.5 miles northeast.

\section{YOUNGER GLACIAL DEPOSITS}

The younger glacial deposits are not as widespread as the older glacial deposits and were formed by mountain glaciers along the bottom of steep-walled valleys that head in large steep-walled cirques. Most occur along the east side of the Continental Divide, although one is found near the mouth of Little Dry Gulch on the east side of the Lemhi River. These glacial deposits are only shown (pl. 1) where they form thick discrete units. Some scattered till is found in several other valleys, such as the valley of North Frying Pan Creek that heads on the east side of the Continental Divide, but the deposit is thin and later erosion has partially removed it and mixed it with more recent sediments.

The younger glacial deposits were formed by valley glaciers moving down the valleys from cirques high on the mountainside. In some areas the glaciers polished the bedrock clear of detrital material, but in other areas it dropped its load. Polished and striated quartzite is exposed in many of the cirques at the head of various tributaries of Bear Creek. Till, however, covers the cirque at the head of the South Fork of Frying Pan Creek.

Glacial till blankets the bottoms and sides of the valleys in fairly even deposits and forms steep-sided moraines. End moraines are not common because in most areas the glacial deposits are confined to narrow valleys and have been subsequently eroded away. The most prominent end moraine occurs at the mouth of Little Dry Gulch, where a pile 400 feet high of poorly sorted quartzite clasts mixed with soil occurs at the edge of the Lemhi Valley. A partial end moraine also is found on the south side of Trapper Creek where several hills as much as 150 feet high stand at the terminus of the glacial deposit. Lateral moraines are more common, and some approximately 50 feet high occur on the northwest side of Bear Creek in the NW $1 / 4$ sec. 35, T. 10 S., R. $15 \mathrm{~W}$., and on the north side of Trapper Creek in the $\mathrm{E}^{1 / 2} \mathrm{sec}$. 33, T. 10 S., R. $15 \mathrm{~W}$. Another forms a prominent ridge on the north side of South Frying Pan Creek in the SW1/4 sec. 29, T. 10 S., R. 15 W., and others are found in several places along Bear and South Frying Pan Creeks. A large medial moraine has formed at the junction of the main north-flowing part of Bear Creek with an east-flowing tributary. This northeast-trending moraine forms a low ridge with an irregular rolling surface. It is 3,700 feet long, 1,200 feet wide, and in places is as much as 120 feet high.

The younger glacial deposits consist of angular, subangular, and subrounded clasts of fine-grained quartzite, and in places a little siltite, in a matrix of sand, silt, and clay. Generally the maximum size of the larger boulders does not exceed 4 feet but in one place along Trapper Creek blocks as much as 20 feet across are found. As the younger glacial deposits are similar in composition to the older glacial deposits, they are separated on the basis of form and occurrence.

\section{TERRACE DEPOSITS}

Terraces represent the remmants of former alluviated valleys that, owing to erosion, now occur above the present valley bottoms. Terraces occur where the old stream 
gradient flattened. Most were probably formed during the Pleistocene when runoff from melting glaciers furnished abundant soil, gravel, and water. They are common along Agency Creek, Pattee Creek and along the east side of the Lemhi River (pl. 1). They are particularly abundant along Agency Creek, where they are found scattered on either side of the valley from about 0.5 mile below the junction with Cow Creek upstream for 5.25 miles to a point about 0.75 mile above the junction with Flume Creek. Terraces are also found along many of the tributaries of Agency Creek, like Cow, Sharkey, White, and Flume Creeks. They are common along the Lemhi River valley, being especially abundant on both sides of the river southeast of the mapped area. The largest terraces shown on plate 1 lie near the junction of the Lemhi River with Yearian Creek. Terraces occur at several different elevations, and in various places were formed at different times. For example, east of the Lemhi River a terrace on either side of Big Dry Gulch has an average elevation of its upper surface of about 5,400 feet but a terrace about 1.5 miles south, adjacent to the Lemhi River, has an elevation of its top of about 5,080 feet. A terrace deposit on Agency Creek northeast of its junction with White Creek has two separate benches indicating that terraces were formed during at least two periods in the development of the valley.

The upper surface of the terraces, although seemingly flat, slopes in two directions. It has a gentle slope parallel to the stream valley, which represents the old stream gradient. It also slopes up the valley sides, owing to the terrace deposits mingling with slopewash from the adjacent hillside.

The terrace deposits are made up of a mixture of brown soil and pebbles, cobbles, and boulders. Most of the clasts are well rounded, but a few are subangular to angular. They range in size from about 0.25 inch to 2 feet in diameter. Most of the clasts are gray, greenish gray, or brown quartzite. Most of the material that makes up the terrace deposits that formed along such streams as Agency and Pattee Creeks was derived from the mountains only a few miles away. Terrace material along the Lemhi River, however, may have come from many miles away from either the Beaverhead Mountains or the Lemhi Range. In addition to material eroded directly off the mountains, a little of it is from reworked glacial deposits. Pebbles from this source may have come from many miles away, which accounts for the rare pebbles of black chert, red quartzite, and coarse-grained biotite granite noted in a few places. The terrace deposits are similar in composition to alluvium. Along the smaller streams they are rarely cultivated owing to the difficulty of irrigating their elevated surfaces. The larger terraces along the Lemhi River, such as the one south of the village of Lemhi, are used for raising hay.

\section{ALLUVIAL FANS}

Pleistocene and Holocene alluvial fans, for the most part, are found along the east side of the Lemhi River valley. They form between the steep mountain slopes and the broad alluviated river valley, and many are found at the mouths of small canyons which contain water only after storms or during the melting of the winter snow. A few fans are also found mantling the area between Reese and Peterson Creeks. Fans along the Lemhi River are being formed at the present time and typically are broad gently sloping surfaces with their apices at the mouths of small canyons. Those in the Reese Creek-Peterson Creek area are somewhat older. Their original smooth surface has been dissected, and both Reese and Peterson Creeks are several hundred feet lower than when most of these fans were formed.

The alluvial fans are made up of subangular to rounded rock fragments mixed with brown sand, silt, and clay. The fragments tend to be angular in the more recent fans and rounded in the older ones. Fragments range in size from 0.25 inch to 3 feet in diameter. Most of the clasts are gray to green fine-grained quartzite. In places a little greenish-gray siltite is present, and in the older fan material between Reese and Peterson Creeks a few small pieces of dark-brown flow rock from the Challis Volcanics are found.

\section{ROCK GLACIER}

One rock glacier of Holocene age is found in the Lemhi Pass thorium district (pl. 1). It lies in a valley on the southeast flank of Goat Mountain in the southeast corner of the area. This rock glacier heads in a cirque and extends for 1 mile down the valley. It has an average width of 850 feet and a tonguelike shape. The glacier has a drop in elevation of 1,150 feet from its upper end in the cirque to its lower end in the creek bottom. The lower terminus is quite steep and the rocks here lie at their angle of repose. This rock glacier is entirely made up of subangular pieces of tan, brown, or gray fine-grained, generally feldspathic quartzite of the Big Creek Formation. Clasts range from a fraction of an inch to 15 feet in diameter. Many pieces are several feet across. Curved ridges a few feet to 20 feet high that are convex to its lower end cross its surface. Movement of this rock glacier has now probably either ceased or is very slow, as a small cabin built on it about 50 years ago does not appear to have been shifted.

\section{LANDSLIDE DEPOSITS}

Landslide deposits of Holocene age are mapped in 18 widely scattered localities in the Lemhi Pass thorium district (pl. 1). They range in size from one north of Pattee Creek that is 200 by 400 feet to one near the center of Yearian Creek basin that is 7,500 feet long and has an average width of 3,300 feet. The largest landslide, however, is only partly in the area and is shown at the southeast corner of plate 1 . This landslide (figs. 11, 12C) underlies most of Little Eightmile Creek basin, having a length of about 3 miles and an average width of almost 1 mile. Some of the areas of landslide deposits are the result of more than one landslide. The 7,500-foot-long area of landslide deposit near the center of Yearian Creek basin is the product of at least four separate landslides (fig. 


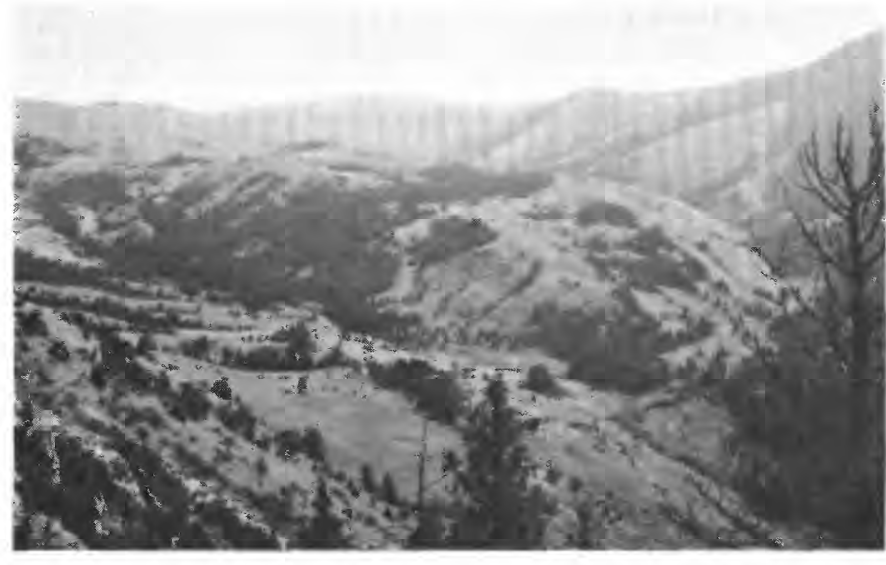

FIGt:RE II. Large landslide filling headwaters of Little Eightmile Creek basin in southeast corner of Lemhi Pass district.

13C). They can be roughly outlined by the various lobes that make up this deposit. They slid south, northwest, east, and west from steep hillsides into the valley of Yearian Creek. The two large landslides southeast of this big landslide deposit each were formed by two coalescing landslides. Another type of multiple landslide is seen along the northwest side of Reese Creek. Here the entire landslide first slid; later a second slide occurred but only the lower part of the old landslide, south of the road, moved. The tops of both movements are marked by prominent scarps. All the landslides are of the slump type. Their upper edges are commonly marked by one or more arcuate scarps. These scarps are particularly well formed on the several landslides that slid off peak 7.073, which lies between Yearian Creek and the South Fork of Yearian Creek. The landslide deposits are all marked by a hummocky surface on which small ponds or springs may be present. Hummocky surfaces are especially well developed on the landslide on the North Fork of Everson Creek near the east edge of the area, the 7,500-foot-long slide near the center of the Yearian Creek basin, and the slide in Little Eightmile Creek basin in the southeast corner of the area (fig. 11). A small pond has formed just below the scarp on the southernmost small landslide on Bear Creek, and several ponds occur scattered in hollows in the large landslide on Little Eightmile Creek. Many of the lakes are ephemeral, but at least in early summer serve as a source of water for cattle. In addition to the small lakes that occur in the irregular poorly drained pockets within the landslides, a small lake was formed on a branch of Yearian Creek owing to damming of a tributary by a landslide.

Most of the landslides overlie or are adjacent to volcanic rocks of various types, either the Challis Volcanics or the tuffaceous sedimentary rocks, and many are adjacent to faults. The volcanic rocks weather much easier than the Precambrian quartzite. Furthermore, the product of weathering of the volcanics is a brown soil which when wet becomes a slippery mud. The tuffaceous sedimentary rocks contain considerable bentonite and make an even more slippery weathering product than the Challis Volcanics. Although the area underlain by the tuffaceous sedimentary rocks is considerably smaller than that underlain by the Challis, some of the larger landslides are found upon it in the Yearian Creek area (fig. 13C). The coincidence of landslides and faults in many places suggests that earthquakes that occur during faulting may have been the triggering mechanism for individual landslides (fig. 2).

The landslides are made up of soil plus various types of rock fragments. The most common type of rock fragment in most landslides is a dark flow rock from the Challis Volcanics. In some slides this is mixed with Precambrian quartzite. In one small slide into a north-flowing tributary of Agency Creek, the rock clasts are entirely of quartzite. The large slide in Little Eightmile Creek has Madison Limestone pieces in addition to those of flow rock and quartzite. Although some of the biggest landslides occur in the tuffaceous sedimentary rocks, fragments of this rock type are not seen in the landslide deposits, as they disintegrate quickly by weathering.

\section{MLDFLOW}

One Holocene mudflow is found on the south side of Agency Creek about 2,000 feet northeast of White Creek. The head of the mudflow is at an elevation of 6,450 feet in Precambrian quartzite just north of the large fault that separates Challis Volcanics from the quartzite. The mudflow moved northwestward for 4,300 feet to Agency Creek, a drop of 850 feet. It had an average width of 500 feet. The most prominent feature of this mudflow is the somewhat sinuous. bumpy ridges 15-30 feet high that bound the edges of the flow. These ridges were formed by drag along its edges. The top of the flow between the small ridges is fairly smooth. The mudflow is made up of angular pieces, $0.12-5 \mathrm{in}$. across, of dark-brown flow rock incorporated in a dark-brown soil.

The mudflow is a fairly recent feature, as it cuts through terrace deposits and its features are sharp and have not been greatly changed by erosion. On the other hand, it was not formed in the last few years, as it was examined in 1952 by Sharp and Cavender (1962, p. 20), and its toe along Agency Creek has been eroded.

\section{ALLCVIUM}

Alluvium makes up the unconsolidated deposits formed in Holocene time along various streams. It occurs where the stream gradient lessens, allowing the sediment to settle out. In most areas this is where the valley widens. The largest area of alluvium is along the Lemhi River valley (partially shown on pl. 1). Other areas containing alluvium are along Peterson, Yearian, Bear, Frying Pan, Trail, Agency, and Pattee Creeks.

Alluvium consists of brown sand, silt, and clay, mixed with some gravel. Gravels are mainly subrounded to rounded Precambrian quartzite, although in some areas a 
few pebbles of dark flow rock or diorite are found. The various types of sediment are commonly well sorted. For example, near Lemhi in the Lemhi Valley, a 1-foot-thick layer of brown silt overlies a several-foot-thick layer of gravel. The relatively small areas of alluvium are the principal areas under cultivation.

\section{STRUCTURE}

The structure of the Lemhi Pass thorium district is moderately complicated, having many faults and folds of diverse trend. Faulting is the major structural element (pl. 1) and both steeply dipping faults and thrust faults are found. Ages of the faults are difficult to estimate unless the faults cut Challis Volcanics or younger rocks and can thus be demonstrated to be of Tertiary or younger age. Some small faults are entirely within rocks of Precambrian age. These faults may also be of Tertiary age, but they could be as old as Precambrian. Much of the faulting, however, is known to have occurred after at least part of the Challis Volcanics of Paleocene(?) and Eocene age were deposited. Little trace of the large faults, which cut Challis Volcanics, was found in the tuffaceous sedimentary rocks within the Yearian Creek graben. Several small north-striking faults offset the tuffaceous sedimentary rocks in the Pattee Creek area, but no large faults were noted. The present position of these rocks also supports the supposition that movement on the major faults was largely complete by the time this rock unit was deposited. The tuffaceous sedimentary rocks are for the most part lake deposits that were formed in basins. These basins originated by faulting during late Challis time and remain essntially unchanged today. One large basin, in which the tuffaceous sedimentary rocks of Pattee Creek are a very small part, lies along the Lemhi and Salmon River valleys. The sediments are much thicker downstream near Salmon and much thinner upstream near Leadore, as they would be if this area had been a lake and received tuffaceous waterborne sediments. As these topographic basins are still intact and show little evidence of later faulting, the major faulting must have been complete by the time the tuffaceous sedimentary rocks were laid down.

Although the attitudes of rocks of different ages indicate that the rocks were deformed during several periods of time, the principal deformation occurred in mid-Tertiary time when the Challis Volcanics were being laid down. The Challis in eastern and central Idaho and its correlative, the Medicine Lodge Volcanics of Scholten and others (1955) of western Montana, were deposited over a large area and mark a time of major tectonism in this part of the country. Tilting of units occurred during the eruption of these volcanic rocks, as can be seen in the northwest part of the area where the gently dipping younger basalt overlies the moderately dipping basalt-rhyodacite sequence, both units of the Challis. Another example is found in the north-central part of the area where gently dipping sanidine-quartz welded tuff overlies more steeply dipping older Challis Volcanics. The greater part of the faulting also probably occurred in mid-Tertiary time.

\section{THRLST FAULTS}

Thrust faults are not common in most of this district and are chiefly confined to the southeast part of the area, although one is found in the northeast corner. The most important fault in the Lemhi Pass district is the Peterson Creek thrust fault (fig. 12A), which separates two geologically distinct provinces. Northwest of and beneath this fault occur the older Precambrian rocks in this district, where sericite was formed in abundance from most of the feldspar by metamorphism. These older rocks are fractured by steep faults and contain all the thorium veins. Southeast of this thrust the Precambrian quartzite belongs to the Swauger Formation and to the Lemhi Group, which are mainly feldspathic and contain only a small amount of sericite. South of the mapped area (pl. 1) in the Goat Mountain quadrangle, these rocks contain lead-silver veins. Although only three other thrusts are shown southeast of the Peterson Creek thrust on plate 1, many more are found south and east in the Goat Mountain (Staatz, 1973) and Leadore quadrangles (Ruppel, 1968), where thrusts are the principal type of faulting (fig. 12B). Paleozoic rocks, chiefly limestones, also occur here; virtually none have been found north and west of the Peterson Creek thrust. These differences in geologic character suggest very large movement along the Peterson Creek thrust, a movement which may well have been several tens of miles. The Peterson Creek thrust can be traced for 5.6 miles across the southeast corner of the district. It has been followed for another 0.5 mile to the southwest in the southern part of the Goat Mountain quadrangle (Staatz, 1973), where it disappears under an alluvial fan. It dips approximately $30^{\circ} \mathrm{SE}$. Along most of its trace it separates different Precambrian units. It is most conspicuous southeast of the junction of the Left and Right Forks of Peterson Creek (fig. 12A), where a small break in slope along the steep mountainside occurs along the trace of the thrust. Several miles south of the Peterson Creek thrust, the large Goat Mountain fault thrusts Madison Limestone over the Big Creek Formation (fig. 12C). The amount of movement is not known but is large, as at least several thousand feet of Precambrian rocks are cut out as well as more than a thousand feet of Paleozoic rocks. The thrust surface of the Goat Mountain fault is undulating and dips $15^{\circ}-35^{\circ} \mathrm{S}$. About 0.5 mile south a somewhat steeper dipping thrust repeats part of the Madison Limestone (fig. 12C). This thrust has had much less movement than the Goat Mountain thrust and may be a subsidiary to the latter thrust, as is indicated by its position and steeper dip. Another thrust is found southeast of the Peterson Creek thrust on the east side of Peterson Creek that moves Swauger Formation over the Big Creek Formation. This fault dips approximately $11^{\circ} \mathrm{W}$. Another thrust occurs in the northeast corner of the district. 

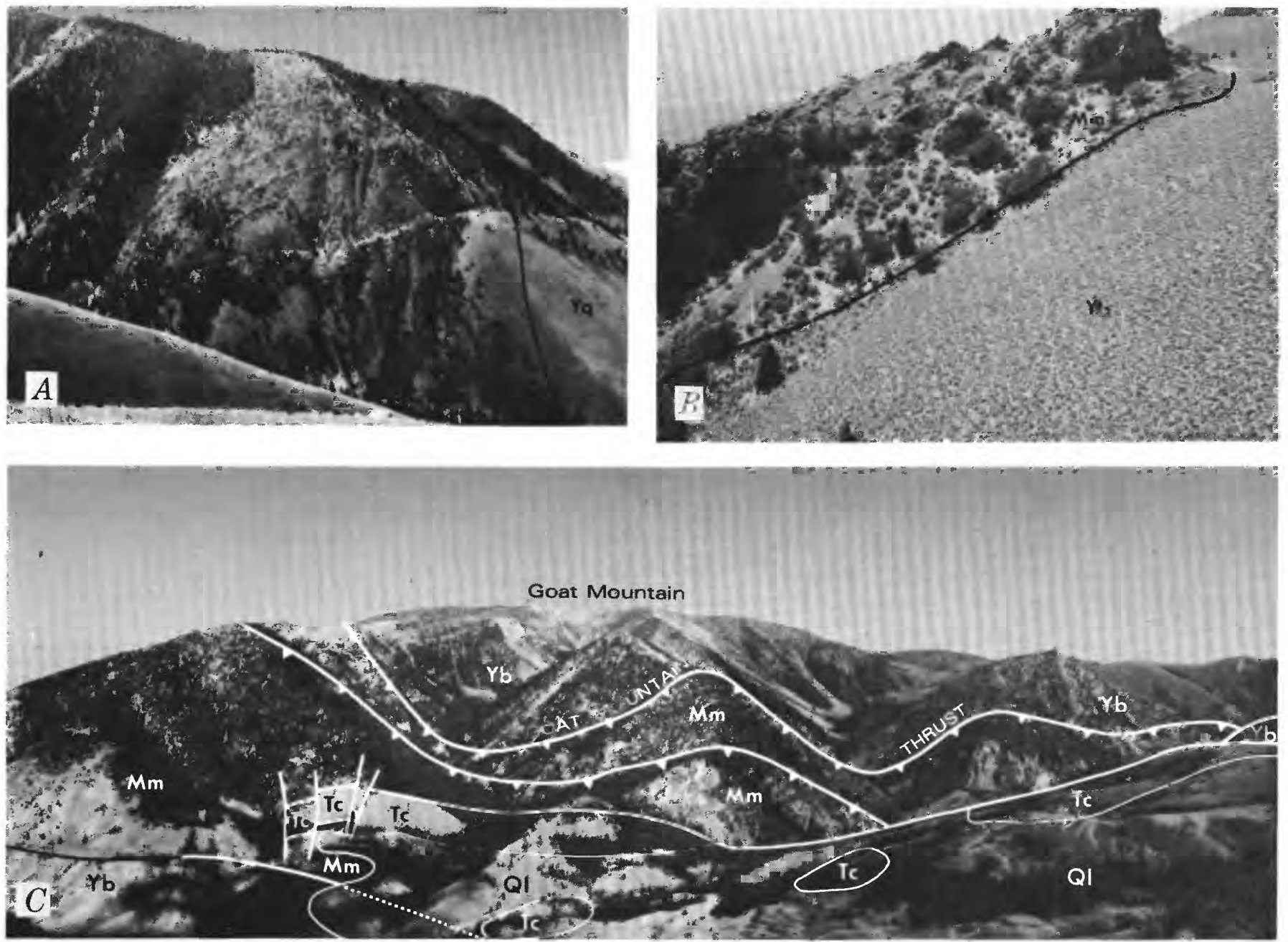

Figlike 12. Thrusts. A, White scar on mountainside marks trace of Peterson Creek thrust. Rocks of upper plate consist of Big (reek Formation $(\mathrm{Yb})$ in thrust contact with Swauger Formation (Ysw); those of the lower plate consist of Precambrian quartzite (Yq) and siltite (Ys). Picture taken looking south across Right Fork of Peterson Creek. B. Light-gray Madison Limestone (Mm) thrust over Big Creek Formation (Yb) 1.5 miles south of the district. $C$. Thrusts (toothed) and steep faults along the southeast side of Goat Mountain in Southeast corner of Lemhi Pass district.Yb, Big Creek Formation; Mm. Madison Limestone; Tc, Challis Volcanics; QI, landslide deposits.

It lies east of Sheser Creek and is marked by a flat ledge of discontinuous quartzite breccia. The ledge forms prominent outcrops as much as 10 feet thick that overlie highly fractured quartzite. Rocks of the Challis Volcanics occur in the upper plate of this thrust. The fault surface curves from practically horizontal near its easternmost exposure to a gentle westerly dip just east of Sheser Creek.

\section{STEEP FAULTS}

Steep faults having diverse trends occur in the district but most strike either northwest or northeast. A few faults have a north to north-northwest trend or a west-northwest to east-northeast trend. Some of them change strike. This is most apparent in some of the longer faults, such as the Lemhi Pass and Dan Patch faults in the northeast part of the district, and the Yearian Creek fault in the central part. A fault that crosses the mouth of Yearian Creek changes trend from N. $84^{\circ} \mathrm{W}$. near its west end to N. $64^{\circ} \mathrm{E}$. in its eastern part. A fault that passes through Wheat Spring in the northern part of the district has an extremely irregular trend that ranges from N. $67^{\circ} \mathrm{W}$. to N. $26^{\circ} \mathrm{E}$.

The faults are of several ages; younger faults offset older ones (fig. 13A). Some of the northeast-trending faults are older than the northwest-trending faults in some parts of the area, but in other parts the reverse is true. This feature is well illustrated in the Yearian Creek graben, a complexly faulted graben that for the most part occupies the Yearian Creek basin. The northeast-trending fault that bounds the west side of this graben is offset by a series of northwest-trending faults. The northwest-trending faults that bound the east side in places are cut by northeast-trending faults, although in another place a northwest-trending fault terminates an 


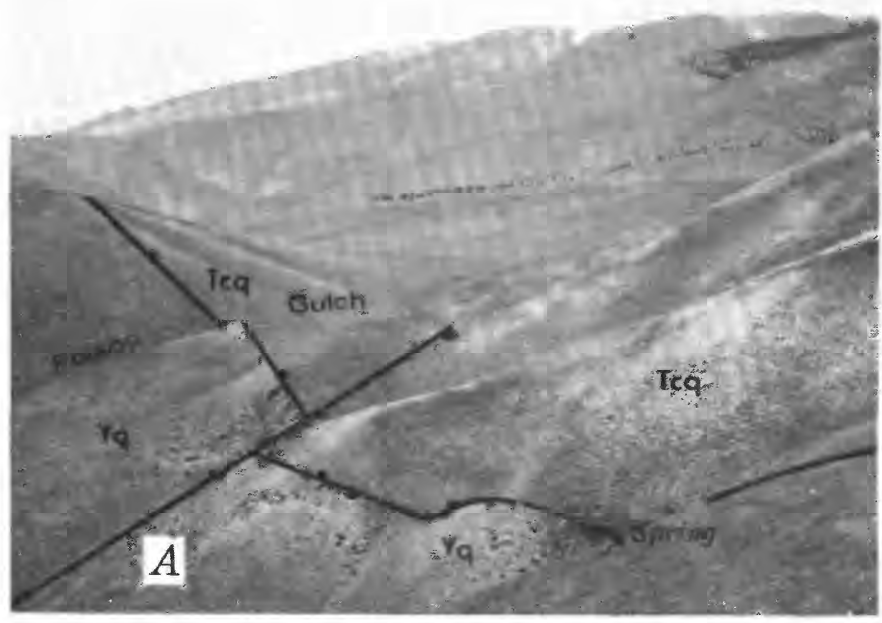

Figt're 13.- Steep faults. $A$, Offset fault separating Precambrian $Y$ quartzite $(\mathrm{Yq})$ from quartzite-bearing rhyolite tuff of the Challis Volcanics (Tcq). Picture taken looking northeast across northwest-flowing tributary of Poison Gulch. B. Lemhi Pass and Dan Patch faults bounding the north and south sides of Ghoul Basin. Precambrian quartzite $(\mathrm{Yq})$ and siltite $(\mathrm{Ys})$ lie north of the Lemhi Pass fault and Challis Volcanics (Tc) lie to the south. Note that two springs originate on the Lemhi Pass fault and one on the Dan Patch fault. Left spring on the Lemhi Pass fault marks campsite of Meriwether Lewis and party of three (Lewis and Clark expedition) on their first night west of the Continental Divide. $C$, Fault along northeast side of the Yearian Creek graben separating Precambrian quartzite (Yq) from hummocky landslide deposits (QI), which overlie Challis Volcanics and tuffaceous sedimentary rocks. Picture taken looking southeast across upper part of Yearian Creek basin.

older northeast-trending fault. Two ages for northwest-trending faults can also be illustrated in the northeastern part of the district where the northwest-striking Dan Patch fault offsets the northwest-trending Bull Moose fault. Thus, there is little correlation between the trend of the faults and their relative age.

Major faults control the position of most of the Challis Volcanics, which are mainly found in down-dropped blocks. In the northeast part of the area three large faults, the Lemhi Pass, Bull Moose, and Dan Patch, bound one or more sides of major outcrop areas of the Challis Volcanics. The Lemhi Pass fault, the northernmost of these, crosses the pass after which it was named by Sharp and Cavender (1962, p. 17). This fault has been traced for 10.6 miles from the eastern to the northern borders of the district. It bounds the north side of Ghoul Basin (fig. 13B) and along much of its trace it forms a topographic sag. An old Indian trail, which was used by Meriwether Lewis and William Clark when they first crossed the Continental Divide, follows the hollow that lies along the northwest 5.3 miles of this fault in this district (pl. 1). Ten springs occur along the trace of the fault. The fault develops a zone of brecciated rock in places at least 20 feet wide. The fault has a strike of about $N$. $70^{\circ} \mathrm{W}$. and a steep dip. The north side of the fault was displaced upward relative to the south side a minimum of 2,000 feet, which is the minimum necessary to account for the vertical separation of the
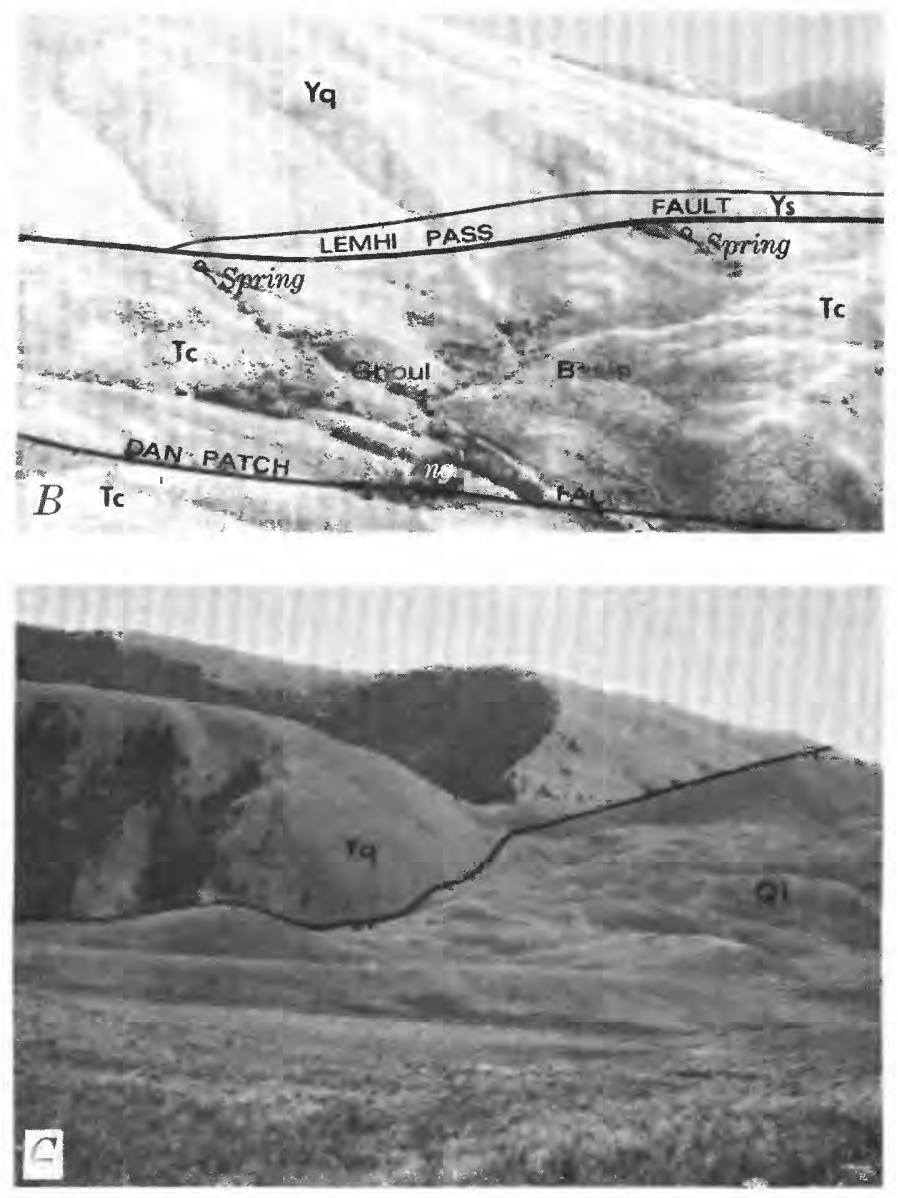

quartzite-bearing rhyolite tuff exposed on the south side of the fault near Lemhi Pass and of that exposed on the north side near the east edge of the district. A steeply dipping fault having at least 1,500 feet vertical displacement branches from the Lemhi Pass fault near the east edge of the district.

The Bull Moose fault, which was named after the Bull Moose vein (loc. 76), bounds the southwestern side of a large block of Challis Volcanics. This fault has been traced for 9.6 miles from the east edge of the district to the headwaters of Agency Creek where it is offset about 1 mile to the southeast by the Dan Patch fault and then cut off by the same fault ( $\mathrm{pl}$. 1). The strike of the Bull Moose fault varies from N. $29^{\circ} \mathrm{W}$. to N. $50^{\circ}$ W.; it has a steep dip. The upthrown side is to the southwest.

The Dan Patch fault, which is named after an adjacent vein (loc. 98), has been traced a distance of 12.3 miles from the east edge of the district to a westward-flowing tributary of Pattee Creek, where it is cut off by the Lemhi Pass fault. In its northern part this fault bounds the southern side of Ghoul Basin (fig. 13B), and in this area four springs, including the Ghoul Basin Spring, are found along its trace. Its southeastern part is somewhat sinuous, ranging from $\mathrm{N} .15^{\circ}$ W. to N. $80^{\circ} \mathrm{W}$. Its dip ranges from nearly vertical to about $50^{\circ} \mathrm{SW}$. Movement along the Dan Patch is large, and the upthrown side is to the northeast. 
In the north-central part of the district the southeast side of the largest block of Challis Volcanics is bounded by the Agency Creek fault. This fault, which was named for the creek that it lies south of and parallels for much of its length, can be traced for 5.4 miles from near the mouth of Flume Creek where it is cut off by the Bull Moose fault to the headwaters of Cow Creek where it terminates on a northwest-trending fault in the Yearian Creek graben. The northeastern part of this fault terminates several north- to north-northwest-trending faults, but its southwestern part is offset in two places by northwest-trending faults. The Agency Creek fault has a general arcuate trend and varies in strike from N. $53^{\circ}$ E. to N. $5^{\circ}$ E.; it has a nearly vertical dip. Movement along this fault is large, and the upthrown side is to the southeast.

The Pattee Creek fault is a sinuous fracture in the northwest part of the district. This fault, which is named after a major creek it crosses, has been traced for approximately 4.5 miles. The north end of this fault terminates against the Lemhi Pass fault and the south end disappears under alluvium. It separates the rocks of Precambrian age on the east from the Challis Volcanics and tuffaceous sedimentary rocks of Tertiary age that fill the Lemhi Valley on the west. The Pattee Creek fault varies in strike from N. $50^{\circ}$ E. to N. $70^{\circ}$ E. Movement is large, and the upthrown side is to the southeast.

In the south-central part of the Lemhi Pass district are two long northeast-trending faults, the Yearian Creek and the Reese Creek faults. The northeast ends of both are in the headwaters of Bear Creek. The northernmost one, the Yearian Creek fault, extends from here southwest along the South Fork of Yearian Creek, from which its name is derived. This fault splits near its center. The main fault has an overall length of 5.8 miles and a strike of about N. $65^{\circ} \mathrm{E}$. On the Continental Divide this fault dips $68^{\circ} \mathrm{SE}$.; to the west it becomes somewhat steeper. Originally this fault (Staatz, 1972 , p. 36) was thought to have formed prior to the emplacement of the Challis Volcanics, but further work has shown that it offsets the Challis near its southwest end. The split fault has an approximate length of 2.2 miles and a strike of $\mathrm{N} .81^{\circ}$ E. Movement along this fault probably occurred several times, not all parts moving at the same time. Movement on the southwest end of the main fault continued after that on the split, as the split is cut off on a northwest-trending fault, but the main part of the Yearian Creek fault offsets this same fault. One to two miles southeast of the Yearian Creek fault is the Reese Creek fault. This fault lies along the northwestern side of the Reese Creek valley, after which it is named. It has a general N. $46^{\circ} \mathrm{E}$. strike and a known length of 6.5 miles. Challis Volcanics along its southwest side indicate that this is the downthrown side.

A major geologic structure, the Yearian Creek graben, occupies most of the Yearian Creek basin. This is a complexly faulted wedge-shaped graben (fig. $13 \mathrm{C}$ ), formed during several periods of faulting. The central part of the graben is poorly exposed as much of it is covered with either landslide debris or older glacial deposits. Where the Quaternary sediments are not present, this part of the graben can be seen to be made up principally of Challis Volcanics and tuffaceous sedimentary rocks, the latter being exposed in the central part and the former along the edges. Quartzites of Precambrian age occur in the surrounding uplifted blocks. The west side of the graben is bounded by a northeast-trending fault that is broken into five segments by northwest-trending cross faults. The east side of the graben is bounded by a northwest-trending fault (fig. 13C) that is cut into four major segments by northeast-trending faults. A small block of silicified siltite has been faulted up in the center of the graben near the junction of Yearian Creek with the South Fork of Yearian Creek. The amount of movement on the graben is difficult to estimate, but the central part of the graben forms a broad valley whose surface is 1,000-1,700 feet below the Ramsey Mountain ridge to the west and 2,000-3,00 feet below the Continental Divide to the east. These, of course, are minimal figures as the uplands to the west and east have been eroded and the Challis Volcanics stripped off them since the graben was formed.

\section{TILTING AND FOLDING}

The rocks in the district also have been tilted and folded. Deformation came at several different times, as angular unconformities occur between the rocks of Precambrian age and the Challis Volcanics, between some of the units within the Challis Volcanics, and between the Challis and the tuffaceous sedimentary rocks. This can be clearly seen north and west of Pattee Creek where the Precambrian quartzites either strike N. $55^{\circ}-75^{\circ} \mathrm{W}$. and $\operatorname{dip} 25^{\circ}-45^{\circ} \mathrm{NE}$. or strike $\mathrm{N}$. $3^{\circ}-44^{\circ}$ E. and dip $15^{\circ}-22^{\circ}$ SE., as compared to the attitude of the nearby Challis Volcanics, which strike N. $25^{\circ} \mathrm{W}$. and dip $42^{\circ} \mathrm{NW}$. To the west this Challis is overlain by the tuffaceous sedimentary rocks that strike $\mathrm{N} .80^{\circ} \mathrm{W}$. to $\mathrm{N} .76^{\circ} \mathrm{E}$. and dip $22^{\circ}-70^{\circ} \mathrm{S}$. The irregular contact of Challis Volcanics on quartzite can be seen west of the Continental Divide and just southwest of Lemhi Pass. Similarly, irregular contacts and diversely dipping beds can be seen between the Challis Volcanics and the tuffaceous sedimentary rocks in the northwest corner of the area on both sides of Pattee Creek.

In general, the rocks of Precambrian age south of the Peterson Creek thrust fault strike north and dip to the east. They have a similar attitude north of the thrust except in the northernmost part of the district where most beds have an approximately east-west strike and dip to the north. Generally the dips are moderate, although in some places they are steep and in a few places they are overturned. Quartzite beds are commonly massive and the bedding may be indistinct. Crossbedding in certain places aids in determining the top sides of the beds. A well-developed clevage is common in the quartzites in much of the eastern half of the area north of the Peterson Creek thrust (pl. 1). Where 
present, it is commonly much more distinct than the bedding, with which it can be easily confused. Cleavage is controlled by parallel orientation of sericite or chlorite. The relation of the attitude of the cleavage to that of the bedding has proved useful in recognizing overturned beds in the Belt Supergroup in the Coeur d'Alene region (Shenon and McConnel, 1940, p. 440-444). 1 have also used the cleavage for determining the top sides of the beds, and where checked against crossbeds, they were found to be in agreement.

Most of the Challis Volcanics strike northwest, although some strike northeast and dip $30^{\circ}$ to $50^{\circ}$ in a northerly direction. In a few places they dip more steeply, and some of the units in the Flume Creek-Agency Creek area are overturned.

The attitudes of the tuffaceous sedimentary rocks may vary from outcrop to outcrop. The strike and dip may be in almost any direction, although the dips are generally $15^{\circ}$ to $40^{\circ}$. This widespread variation, although in part due to later deformation, appears in large part to be due to the original dip of the beds, which were laid down on an irregular topography.

Although folding is much less common than faulting, eight relatively small folds occur in the district. Five of the folds are entirely in Precambrian quartzite, two are in the Challis Volcanics, and one in tuffaceous sedimentary rocks. Whether they were all formed in late Tertiary time or whether they formed at several different times is not certain. They range in traceable length from 0.3 to 3.6 miles. The largest fold is a syncline which lies in a horst of quartzite between the Dan Patch and Bull Moose faults in the eastern part of the district. Northeast of it, across the Bull Moose fault, an anticline and a syncline occur in the Challis Volcanics. Although the axes of six of the folds have a northwest strike, they are for the most part not parallel. The folds apparently are produced by local stresses rather than by regional forces, as indicated by their wide areal distribution, relative shortness, and diverse trends.

\section{VEINS}

Four kinds of veins are found in the Lemhi Pass thorium district: (1) Thorium veins, (2) copper veins, (3) iron veins, and (4) barren quartz veins. Thorium veins greatly outnumber the other types of veins, making up 87 percent of the 251 veins found in this area. Copper and barren quartz veins each make up 6 percent of the total and iron veins less than 1 percent.

With but one exception, all the veins in the district intrude rocks of Precambrian age. The veins lie north of the Peterson Creek thrust fault, and the country rock is chiefly a fine-grained micaceous quartzite. The 14 veins at localities 1 , $14,135,149,182,183,188,190,191$, and 192, however, occur in siltite. As the quartzite is much more widespread than the siltite, either rock type appears equally favorable as a host rock for veins.

\section{THORIUM VEINS}

Thorium veins are scattered over a large area in the Lemhi Pass district ( $\mathrm{pl}$. 1). The veins are in shear zones, and commonly both parallel and en echelon veins occur in the same zone. Where the vein or veins are exposed only in a series of trenches, the extension of a particular vein and the number of veins present may be difficult to determine. An example of this is at the Shear Zone vein (loc. 75), which consists of a series of veins, lenses, and secondary splits that occur almost continuously for more than 6,000 feet. In some trenches several distinct veins are exposed, but in others there may be only one. Where several closely spaced veins occur in one zone, they may not be shown on plate 1. Each vein locality, however, is given a separate number, and each vein at every locality is noted in table 2 . The number of closely spaced veins at any locality ranges from one to six. Thorium veins occur at 173 of the 195 vein localities shown on plate 1. A total of 219 thorium veins are known from these various localities. Generally only one major vein was found at any locality.

Although claim names are known for many veins at various localities, numbers were used instead of claim names for several reason: (1) Names on many claims could not be ascertained owing to loss or destruction of notices, (2) boundary markers commonly have disappeared, and (3) some veins are on several claims. Names, where known, are given in table 2 and throughout the text.

Although the veins are widely scattered, they tend to be concentrated in three more or less distinct areas: (1) A fairly large area in the northeastern part of the district in the headwaters of Agency and North Frying Pan Creeks, (2) the northwestern part of the district along the Pattee Creek drainage, and (3) an area across part of the headwaters of Peterson, Reese, and Yearian Creeks. Scattered veins occur in other areas. Veins in the southwest part of the district, on the mountain block dominated by Ramsey Mountain, tend to be small, scattered, and low grade. In addition to the veins shown on plate 1 , a vein is found on the north side of McDevitt Creek, 4 miles west-southwest of Tendoy, and several stringers occur in a shear zone on the Daisy Nielsen ranch near the headwaters of Sandy Creek, 4.3 miles north-northwest of Poison Gulch Spring in the northwest part of the mapped area. None of these veins is large.

Few thorium veins are exposed. Those which crop out generally are those which have a high quartz content and are on a ridge. The veins are primarily made up of quartz, microcline, and various iron oxides. At the surface, the microcline commonly weathers and the iron oxides become soft and pulverulent. Only a vein consisting mostly of quartz will be more resistant than the surrounding country rock and protrude above it. Thorium-bearing minerals tend to be concentratedi in the iron-oxide-rich parts of the vein. Thus, parts of veins that crop out are generally less radioactive than those parts that do not. A glance at the map (pl. 1) will 
show the presence of many veins along ridges. Some veins, such as the Last Chance (loc. 82), Cago No. 12 (loc. 49), Lucky Horseshow (loc. 1), and Silver Queen 52B (loc. 146) were first discovered on ridges and then extended into covered areas by a series of trenches. Many areas that are under thick soil cover have been virtually unexplored. Although a great number of bulldozer trenches are found in parts of this area, most of the exploration has been rather superficial. The principal reasons are that radioactive minerals were of no economic interest until the late 1940's, and there is currently (1976) no open market for thorium. The sudden demand for uranium in the late 1940's led to widespread exploration for radioactive deposits throughout the United States. Radioactive deposits were first discovered in the Lemhi Pass district in the spring of 1949 by Wayne Hinman (Jarrard, 1957, p. 46). The original discovery encouraged a flood of prospectors to come into this area and many additional discoveries were made in the next few years. The original exploration was in the northern part of the district, where most of the prospects are located. Veins were found in the southern part of the area by the 1950's. The lack of a ready market for thorium caused a gradual lessening of prospecting activity. Prospectors having claims either sold their properties or tried to hold on until a market for thorium developed. Some of the prospectors banded together to form small companies in order to better handle the assessment work. From about 1965 through 1974 most of the activity was assessment work and little new prospecting was carried out.

\section{SIZE AND ATTITUDE}

The thorium veins are relatively thin tabular bodies having widely varying dimensions (fig. $14 A, B, C$ ). They range in length from a few feet to at least 4,350 feet. The known lengths of the various veins in the district are given in table 2. Because of poor exposures (fig. 14B), all are

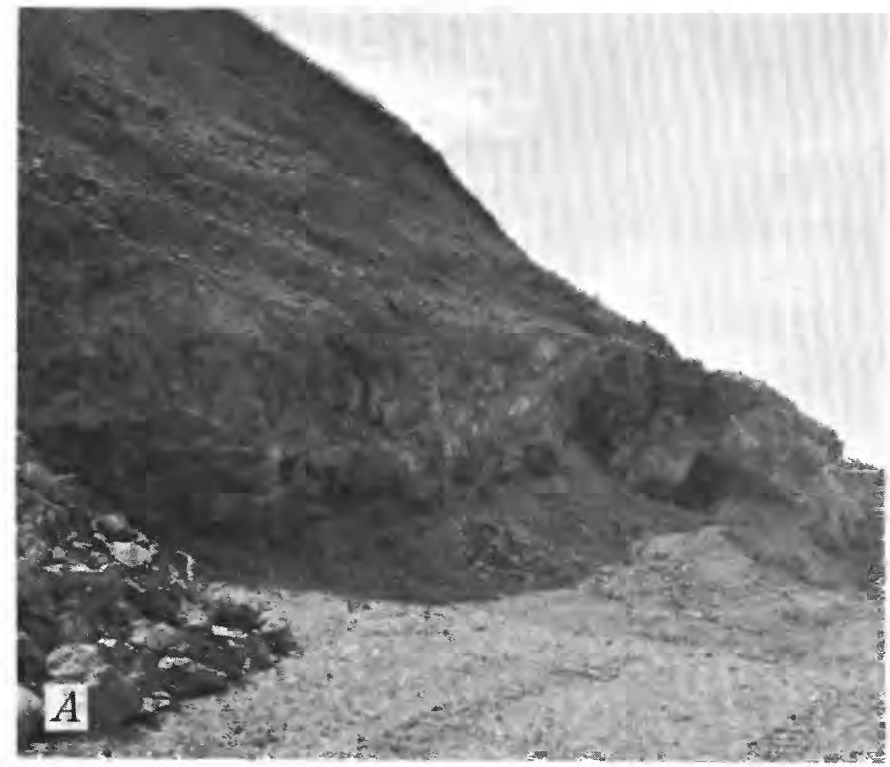

minimum lengths. Some veins, such as those at localities 2 , $11,62,68,77,80,117,120$, and 149 , are exposed at only one spot in a trench, and their continuity, if any, is not known. Others can be traced possibly 6 feet across or along a single trench. The vein of longest continuous known length is the Last Chance (loc. 82). The Shear Zone vein, which appears longer, having been traced for 6,000 feet, is actually a shear zone along which several closely spaced branching and en echelon veins are found. Owing to poor exposures of this zone, the exact length of the several veins is poorly known, and the entire zone is treated as a single unit in table 2.
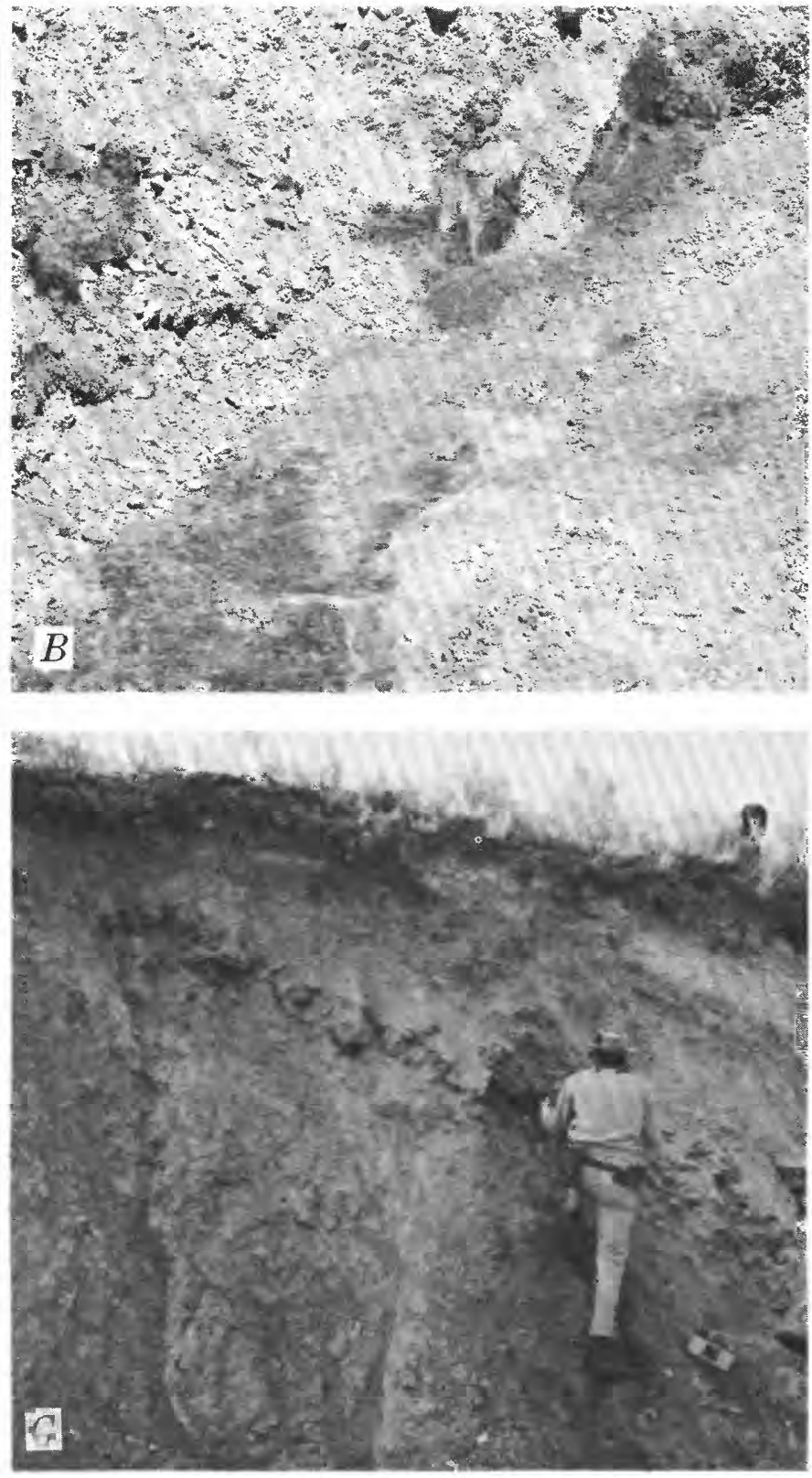

Figure 14.-Thorium veins. $A$, South vein (black) of Silver Queen 52B (loc. 146) dipping into wall of cut. $B$, Northwestern end of vein (dark gray) at locality 122 exposed in a bulldozer trench on the Continental Divide. C, 1-foot-thick vein, at locality 150 in wall of a cut, is in gouge of the Pattee Creek fault. 
TABLE 2.-Dimensions and attitude of thorium veins in the Lemhi Pass area [n.d., not determined]

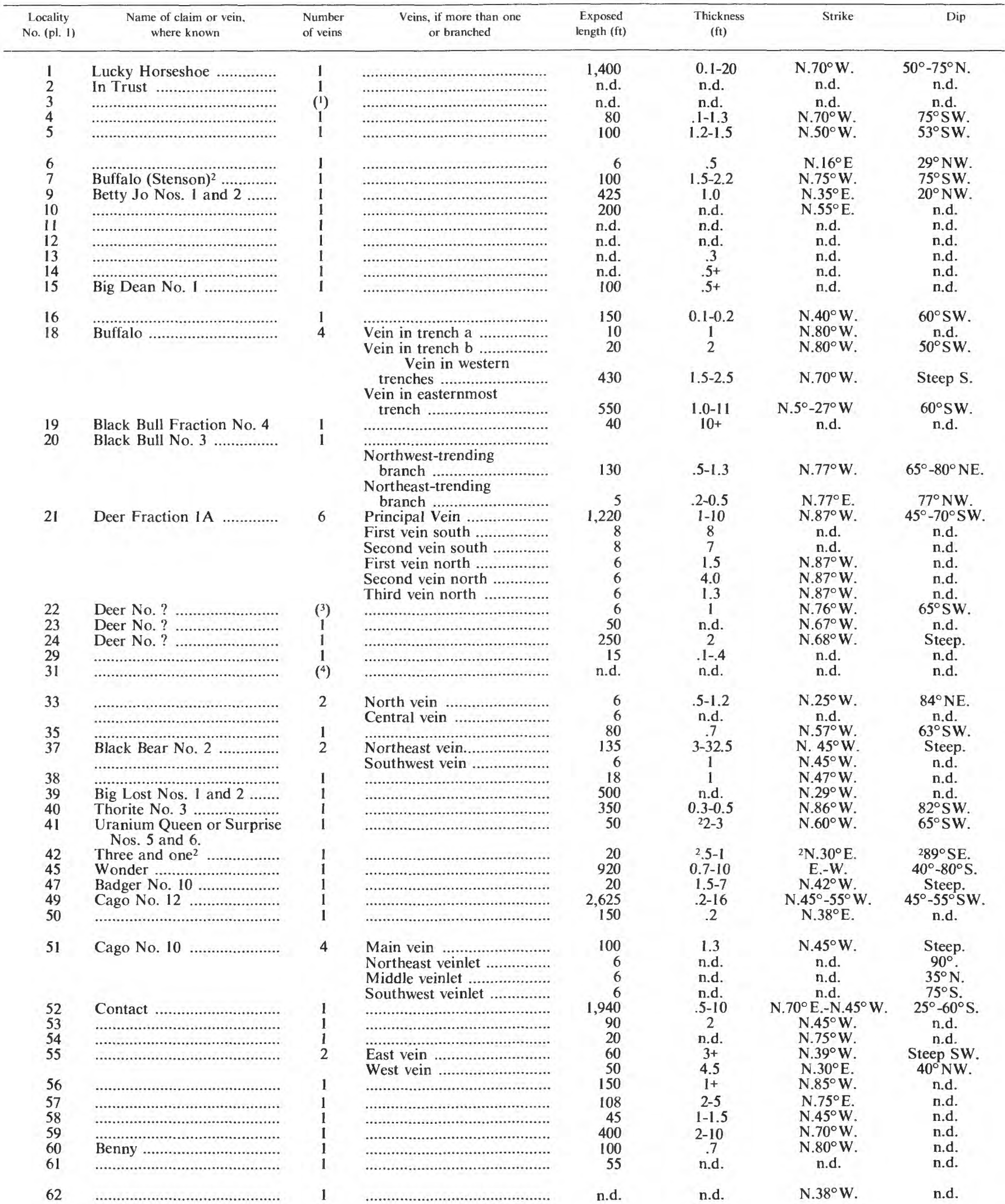


TABIE 2.- Dimensions and attitude of thorium veins in the Lemhi Pass area-Continued

\begin{tabular}{|c|c|c|c|c|c|c|c|}
\hline $\begin{array}{l}\text { Locality } \\
\text { No. (pi. I) }\end{array}$ & $\begin{array}{l}\text { Name of claim or veln, } \\
\text { where known }\end{array}$ & $\begin{array}{l}\text { Number } \\
\text { of veins }\end{array}$ & $\begin{array}{l}\text { Veins, if more than one } \\
\text { or branched }\end{array}$ & $\begin{array}{l}\text { Exposed } \\
\text { length (ft) }\end{array}$ & $\begin{array}{l}\text { Thickness } \\
\text { (ft) }\end{array}$ & Strike & Dıp \\
\hline $\begin{array}{l}63 \\
64 \\
65 \\
66\end{array}$ & Beaverhead (Montana) & $\begin{array}{l}1 \\
1 \\
1 \\
1\end{array}$ & , & $\begin{array}{r}72 \\
520 \\
15 \\
140\end{array}$ & $\begin{array}{l}.9 \\
9-25 \\
\text { n.d. } \\
3-8\end{array}$ & $\begin{array}{l}\text { N. } 75^{\circ} \mathrm{W} \\
\text { N. } 80^{\circ} \mathrm{W} . \\
\text { n.d. } \\
\text { N. } 77^{\circ} \mathrm{E} \text {. }\end{array}$ & $\begin{array}{l}\text { n.d. } \\
50^{\circ} \mathrm{SW} . \\
\text { n.d. } \\
\text { n.d. }\end{array}$ \\
\hline $\begin{array}{l}67 \\
68\end{array}$ & $\begin{array}{l}\text { Trapper No. } 1 \\
\text { Lucky R or Little } \\
\text { Dandy No. } 5 .\end{array}$ & 1 & 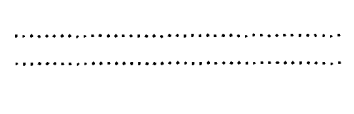 & $\begin{array}{l}235 \\
\text { n.d. }\end{array}$ & $\begin{array}{l}5-11 \\
\text { n.d. }\end{array}$ & $\begin{array}{l}\text { N. } 75^{\circ}-85^{\circ} \mathrm{W} \\
\text { n.d. }\end{array}$ & $\begin{array}{l}45^{\circ}-60^{\circ} \mathrm{SW} \\
\text { n.d. }\end{array}$ \\
\hline $\begin{array}{l}69 \\
70\end{array}$ & 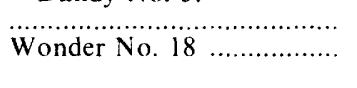 & $\begin{array}{l}1 \\
2\end{array}$ & $\begin{array}{l}\text { North vein } \\
\text { Central vein }\end{array}$ & $\begin{array}{l}\text { n.d. } \\
\text { n.d. } \\
550\end{array}$ & $\begin{array}{l}\text { n.d. } \\
1.0 \\
0.7-1.2\end{array}$ & $\begin{array}{l}\text { n.d. } \\
\text { N. } 75^{\circ} \mathrm{W} \text {. } \\
\text { N. } 70^{\circ} \mathrm{W} \text {. }\end{array}$ & $\begin{array}{l}\text { n.d. } \\
\text { n.d. } \\
50^{\circ}-65^{\circ} \mathrm{SW} \text {. }\end{array}$ \\
\hline $\begin{array}{l}72 \\
73\end{array}$ & $\begin{array}{l}\text { Little Dandy No. } 1 \\
\text { Shear Zone }\end{array}$ & $\begin{array}{l}1 \\
(5)\end{array}$ & , & $\begin{array}{r}95 \\
6,000\end{array}$ & $\begin{array}{l}1.0-2.5 \\
.5-2.5\end{array}$ & $\begin{array}{l}\text { N. } 78^{\circ} \mathrm{W} \\
\text { N. } 55^{\circ} \mathrm{W}\end{array}$ & $65^{\circ}-80^{\circ} \mathrm{SW}$ \\
\hline $\begin{array}{l}74 \\
75\end{array}$ & $\begin{array}{l}\text { Dictator No. } 6 \\
\text { Black Rock or Radio } 2\end{array}$ & $\begin{array}{l}1 \\
2\end{array}$ & $\begin{array}{l}\text { Northwest-trending vein ... } \\
\text { Northeast-trending vein .... }\end{array}$ & $\begin{array}{r}\text { n.d. } \\
1,610 \\
135\end{array}$ & $\begin{array}{l}.1 \\
1.3-6 \\
.7-1\end{array}$ & $\begin{array}{l}\text { n.d. } \\
\text { N. } 47^{\circ} \mathrm{W} . \\
\text { N. } 75^{\circ} \mathrm{E} .\end{array}$ & $\begin{array}{l}\text { n.d. } \\
70^{\circ}-75^{\circ} \mathrm{SW} \\
75^{\circ}-80^{\circ} \mathrm{NW}\end{array}$ \\
\hline $\begin{array}{l}76 \\
77\end{array}$ & $\begin{array}{l}\text { Bull Moose } 2 \\
\text { Brown Bear No. } 3 \ldots \ldots \ldots \ldots \ldots . . .\end{array}$ & 1 & (1) & $\begin{array}{r}260 \\
\text { n.d. }\end{array}$ & $\begin{array}{l}2.1-0.3 \\
\text { n.d. }\end{array}$ & $\begin{array}{l}\text { N. } 45^{\circ} \mathrm{W} \text {. } \\
\text { n.d. }\end{array}$ & $\begin{array}{l}85^{\circ} \mathrm{SW} . \\
\text { n.d. }\end{array}$ \\
\hline 78 & Brown Bear No. 2 ............. & 2 & $\begin{array}{l}\text { North vein } \ldots \ldots \ldots \ldots \ldots \ldots \ldots \\
\text { South vein } \ldots \ldots \ldots \ldots \ldots \ldots \ldots \ldots \ldots \ldots \ldots \ldots \ldots\end{array}$ & $\begin{array}{r}65 \\
400\end{array}$ & $\begin{array}{l}1 \\
.5\end{array}$ & $\begin{array}{l}\mathrm{N} .79^{\circ} \mathrm{W} \\
\mathrm{N} .80^{\circ} \mathrm{W}\end{array}$ & $\begin{array}{l}\text { n.d. } \\
\text { n.d. }\end{array}$ \\
\hline $\begin{array}{l}79 \\
80 \\
82\end{array}$ & $\begin{array}{l}\text { Skyline No. } 1 \text {. } \\
\text { Brown Bear No. } 5 \ldots \ldots \ldots \ldots \ldots \ldots \\
\text { Last Chance } \ldots \ldots \ldots \ldots \ldots \ldots \ldots \ldots\end{array}$ & $\begin{array}{l}1 \\
1 \\
1\end{array}$ & (1) & $\begin{array}{r}100 \\
\text { n.d. } \\
4.350\end{array}$ & $\begin{array}{l}.4 \\
\text { n.d. } \\
5-40\end{array}$ & $\begin{array}{c}\text { N. } 70^{\circ} \mathrm{W} \\
\text { n.d. } \\
\text { N. } 40^{\circ}-80^{\circ} \mathrm{W} .\end{array}$ & $\begin{array}{l}\text { n.d. } \\
\text { n.d. } \\
40^{\circ}-70^{\circ} \mathrm{SW} \text {. }\end{array}$ \\
\hline $\begin{array}{l}83 \\
85\end{array}$ & $\begin{array}{l}\text { Big Horn . } \\
\text { Frying Pan and Frying } \\
\text { Pan No. 22. }\end{array}$ & $\begin{array}{l}1 \\
3\end{array}$ & 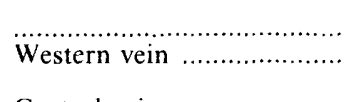 & $\begin{array}{c}\text { n.d. } \\
100\end{array}$ & .5 & N. $30^{\circ} \mathrm{W}$. & $\begin{array}{c}\text { n.d. } \\
54^{\circ} \mathrm{SW} \text {. }\end{array}$ \\
\hline $\begin{array}{l}86 \\
87 \\
88\end{array}$ & 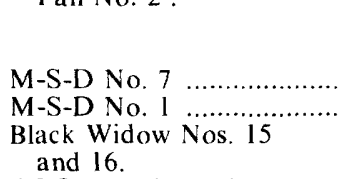 & $\begin{array}{l}1 \\
1 \\
1\end{array}$ & $\begin{array}{l}\text { Central vein } \\
\text { Southeast vein }\end{array}$ & $\begin{array}{r}10 \\
1,100 \\
30 \\
20 \\
10\end{array}$ & $\begin{array}{l}.7 \\
.5-.7 \\
.5+ \\
2-2.5 \\
\text { n.d. }\end{array}$ & $\begin{array}{l}\text { N. } 55^{\circ} \mathrm{W} . \\
\text { N. } 36^{\circ}-73^{\circ} \mathrm{W} . \\
\text { N. } 48^{\circ} \mathrm{W} . \\
\text { N. } 30^{\circ} \mathrm{W} \\
\text { N. } 55^{\circ} \mathrm{W} .\end{array}$ & $\begin{array}{l}\text { n.d. } \\
72^{\circ}-78^{\circ} \mathrm{SW} \\
\text { n.d. } \\
60^{\circ} \mathrm{SW} \\
\text { n.d. }\end{array}$ \\
\hline $\begin{array}{l}89 \\
90\end{array}$ & $\begin{array}{l}\text { G\&G Nos. } 6 \text { and } 8 \ldots \ldots \ldots \\
\text { G\&G Nos. } 1,2 \text {, and } 5 \ldots \ldots\end{array}$ & $\begin{array}{l}1 \\
2\end{array}$ & $\begin{array}{l}\text { North vein } \\
\text { South vein }\end{array}$ & $\begin{array}{r}1,300 \\
1,600 \\
55\end{array}$ & $\begin{array}{l}1-2 \\
.8-2 \\
\text { n.d. }\end{array}$ & $\begin{array}{l}\text { N. } 48^{\circ} \mathrm{W} \\
\text { N. } 48^{\circ} \mathrm{W} \\
\text { N. } 35^{\circ} \mathrm{W}\end{array}$ & $\begin{array}{l}\text { Steep. } \\
58^{\circ} \mathrm{SW} \text {. } \\
\text { Steep. }\end{array}$ \\
\hline $\begin{array}{l}91 \\
92\end{array}$ & $\begin{array}{l}\text { B. and B. Nos. } 1 \text { and } 4 \ldots . \\
\text { Atomic Blast Nos. } 7 \\
\text { and } 8 \text {. }\end{array}$ & $\begin{array}{l}1 \\
1\end{array}$ & (n) & $\begin{array}{r}20 \\
\text { n.d. }\end{array}$ & $\begin{array}{l}.5 \\
\text { n.d. }\end{array}$ & $\begin{array}{l}\text { N. } 74^{\circ} \mathrm{W} \text {. } \\
\text { n.d. }\end{array}$ & $\begin{array}{l}90^{\circ} \\
\text { n.d. }\end{array}$ \\
\hline $\begin{array}{l}93 \\
94 \\
95 \\
96\end{array}$ & 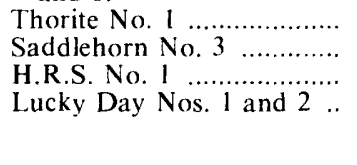 & $\begin{array}{l}1 \\
1 \\
1 \\
2\end{array}$ & 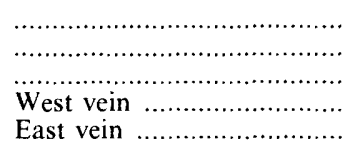 & $\begin{array}{r}300 \\
300 \\
20 \\
25 \\
85\end{array}$ & $\begin{array}{l}.9 \\
.2-.5 \\
0.9 \\
.5 \\
1\end{array}$ & $\begin{array}{l}\text { N. } 45^{\circ} \mathrm{W} \\
\mathrm{N} .41^{\circ} \mathrm{W} \\
\mathrm{N} .70^{\circ} \mathrm{E} \\
\mathrm{N} .45^{\circ} \mathrm{W} \\
\text { N. } 38^{\circ} \mathrm{W}\end{array}$ & $\begin{array}{l}85^{\circ} \mathrm{NE} . \\
\text { n.d. } \\
45^{\circ} \mathrm{SE} . \\
\text { n.d. } \\
90^{\circ} .\end{array}$ \\
\hline $\begin{array}{c}97 \\
98 \\
99 \\
100 \\
101\end{array}$ & . & $\begin{array}{l}1 \\
2 \\
1 \\
1 \\
1\end{array}$ & $\begin{array}{l}\text { North vein } \\
\text { South vein } \ldots \ldots \ldots \ldots \ldots \ldots \ldots \ldots \ldots \ldots \\
\end{array}$ & $\begin{array}{l}\text { n.d. } \\
508 \\
105 \\
225 \\
150 \\
100\end{array}$ & $\begin{array}{l}\text { n.d. } \\
2.0-2.5 \\
.5-6 \\
.5-0.8 \\
5.7 \\
\text { n.d. }\end{array}$ & $\begin{array}{l}\text { n.d. } \\
\text { N. } 75^{\circ} \mathrm{W} \\
\text { N. } 40^{\circ}-77^{\circ} \mathrm{W} \\
\text { N. } 81^{\circ} \mathrm{W} \\
\text { N.82 } \\
\text { N. } 80^{\circ} \mathrm{W} \\
\end{array}$ & $\begin{array}{c}\text { n.d. } \\
55^{\circ}-75^{\circ} \mathrm{SW} . \\
70^{\circ} \mathrm{SW}-90^{\circ} \\
\text { n.d. } \\
82^{\circ} \mathrm{SW} . \\
\text { n.d. }\end{array}$ \\
\hline $\begin{array}{l}102 \\
103 \\
104\end{array}$ & $\begin{array}{l}\text { Big Thor Nos. } 1 \text { and } 2 \ldots \ldots \\
\text { Silvertip Nos. 1, 2, and } 3 \text {.. }\end{array}$ & $\begin{array}{l}1 \\
1 \\
2\end{array}$ & $\begin{array}{l}\text { North vein } \ldots \ldots \ldots \ldots \ldots \ldots \ldots \ldots \ldots \\
\text { South vein }\end{array}$ & $\begin{array}{r}125 \\
50 \\
25 \\
50\end{array}$ & $\begin{array}{l}.3 \\
\text { n.d. } \\
1.0 \\
\text { n.d. }\end{array}$ & $\begin{array}{l}\text { N. } 65^{\circ} \mathrm{W} \\
\text { N. } 36^{\circ} \mathrm{W} \\
\text { N. } 50^{\circ} \mathrm{W} \\
\text { N. } 35^{\circ} \mathrm{W}\end{array}$ & $\begin{array}{l}\text { Steep. } \\
\text { n.d. } \\
\text { n.d. } \\
\text { n.d. }\end{array}$ \\
\hline 105 & Atomic Blast ....................... & 2 & $\begin{array}{l}\text { North vein } \\
\text { South vein }\end{array}$ & $\begin{array}{r}15 \\
225\end{array}$ & $.1-1.3$ & $\begin{array}{l}\text { N.31 } \\
\text { N. } 65^{\circ} \text { E. }-\mathrm{N} .82^{\circ} \mathrm{W}\end{array}$ & $\begin{array}{l}20^{\circ} \mathrm{SE} . \\
\text { n.d. }\end{array}$ \\
\hline $\begin{array}{l}106 \\
107\end{array}$ & $\begin{array}{l}\text { Orpha } \\
\text { Reactor Nos. } 1,3, \text { and } 5 \ldots\end{array}$ & $\begin{array}{l}1 \\
4\end{array}$ & $\begin{array}{l}\text { Northeast vein } \\
\text { Southwest vein } \ldots \ldots \ldots \ldots \ldots \ldots \ldots . . . \\
\text { Northwest vein } \\
\text { Southeast vein }\end{array}$ & $\begin{array}{r}115 \\
1,300 \\
74 \\
290 \\
656\end{array}$ & $\begin{array}{c}6 \\
.8-5 \\
1-3 \\
1-3.5 \\
.3-.5\end{array}$ & $\begin{array}{l}\mathrm{N} .55^{\circ} \mathrm{W} . \\
\text { N. } 28^{\circ}-48^{\circ} \mathrm{W} . \\
\text { N. } 63^{\circ} \mathrm{W} . \\
\text { N. } 23^{\circ} \mathrm{W} \\
\text { N. } 28^{\circ}-48^{\circ} \mathrm{W} .\end{array}$ & $\begin{array}{l}\text { n.d. } \\
70^{\circ}-85^{\circ} \mathrm{SW} \\
55^{\circ} \mathrm{SW} . \\
45^{\circ} \mathrm{SW} . \\
\text { n.d. }\end{array}$ \\
\hline $\begin{array}{l}108 \\
109 \\
110 \\
111\end{array}$ & $\begin{array}{l}\text { Elkhorn } \\
\text { Lucky Strike No. } 2 \\
\ldots \ldots \ldots \ldots \ldots . . . \\
\mathrm{ThO}_{2} \text { Nos. } 5 \text { and } 6 \ldots \ldots \ldots . . .\end{array}$ & $\begin{array}{l}1 \\
1 \\
1 \\
2\end{array}$ & 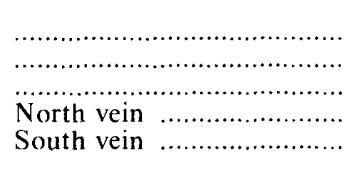 & $\begin{array}{r}630 \\
9+ \\
225 \\
20 \\
20\end{array}$ & $\begin{array}{l}.04-1.5 \\
1.5 \\
.3-2 \\
2 \\
3\end{array}$ & $\begin{array}{l}\text { N. } 28^{\circ}-55^{\circ} \mathrm{W} \\
\text { N. } 72^{\circ} \mathrm{W} \\
\text { N. } 53^{\circ} \mathrm{W} \\
\text { N. } 86^{\circ} \mathrm{W} \\
\text { N. } 86^{\circ} \mathrm{W}\end{array}$ & $\begin{array}{c}90^{\circ} \\
49^{\circ} \mathrm{NE} . \\
50^{\circ} \mathrm{SW} .-90^{\circ} \\
90^{\circ} \\
90^{\circ}\end{array}$ \\
\hline 112 & Lucky Strike No. 3 ............ & 1 & (n) & 10 & 1 & E.-W. & $80^{\circ} \mathrm{N}$ \\
\hline
\end{tabular}




\begin{tabular}{|c|c|c|c|c|c|c|c|}
\hline $\begin{array}{l}\text { Locality } \\
\text { No. (pl. 1) }\end{array}$ & $\begin{array}{l}\text { Name of claim or vein. } \\
\text { where known }\end{array}$ & $\begin{array}{l}\text { Number } \\
\text { of veins }\end{array}$ & $\begin{array}{l}\text { Veins, it more than one } \\
\text { or branched }\end{array}$ & $\begin{array}{l}\text { Exposed } \\
\text { length }(\mathrm{ft})\end{array}$ & $\begin{array}{l}\text { Thickness } \\
\text { (ft) }\end{array}$ & Strike & Dip \\
\hline 113 & $\begin{array}{l}\text { Chief Tendoy Nos. } 13 \\
\text { and } 14 .\end{array}$ & 1 & (2) & 200 & 1 & N. $33^{\circ} \mathrm{W}$. & $75^{\circ} \mathrm{SW}$ \\
\hline 114 & Welco No. $10 \ldots \ldots \ldots \ldots$ & 1 & …… & $50+$ & 0.4 & N. $58^{\circ} \mathrm{W}$. & n.d. \\
\hline 115 & Chief Tendoy No. 6 ............ & 1 & 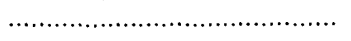 & $50+$ & n.d. & N. $68^{\circ} \mathrm{W}$ & n.d. \\
\hline 116 & Chief Tendoy No. 3 ........... & & 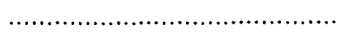 & 50 & n.d. & N. $47^{\circ} \mathrm{W}$. & n.d. \\
\hline 117 & 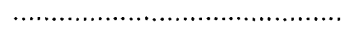 & 1 & 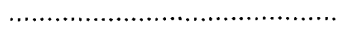 & n.d. & n.d. & n.d. & n.d. \\
\hline & 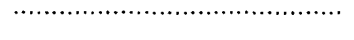 & & 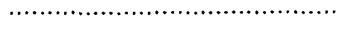 & n.d. & 1.3 & n.d. & n.d. \\
\hline 119 & $\cdots$ & 1 & $\cdots$ & n.d. & $.7+$ & n.d. & n.d. \\
\hline 120 & & 1 & & n.d. & .5 & n.d. & n.d. \\
\hline \multirow[t]{3}{*}{121} & Chief Tendoy No. 2 ........... & 3 & Vein in west pit ...................... & n.d. & n.d. & n.d. & n.d. \\
\hline & & & $\begin{array}{l}\text { North vein, east pit } \ldots \ldots \ldots \ldots \\
\text { South vein, east pit } \ldots \ldots \ldots \ldots \ldots\end{array}$ & $\begin{array}{l}3 \\
3\end{array}$ & $\begin{array}{l}.5 \\
\text { n.d. }\end{array}$ & $\begin{array}{l}\text { n.d. } \\
\text { n.d. }\end{array}$ & $\begin{array}{l}35^{\circ} \mathrm{NW} \text {. } \\
\text { n.d. }\end{array}$ \\
\hline & & & 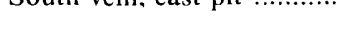 & & & & \\
\hline 122 & Mining claim No. 7 & 1 & 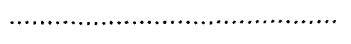 & 950 & $.8-1.5$ & N. $32^{\circ}-45^{\circ} \mathrm{W}$ & $71^{\circ} \mathrm{SW}$ \\
\hline 123 & $\begin{array}{l}\text { Mining claim No. } 7 \\
\text { Thorelsen No. } 2\end{array}$ & 1 & 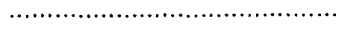 & 550 & $.5-2$ & $\mathrm{~N} .83^{\circ} \mathrm{E}$ & n.d. \\
\hline 124 & & 1 & 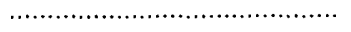 & 16 & 3.5 & N. $57^{\circ} \mathrm{W}$ & $78^{\circ} \mathrm{NE}$ \\
\hline 125 & Welco Nos. 8 and $9 \ldots \ldots \ldots$ & 1 & . & $15+$ & 3.1 & $\mathrm{~N} .70^{\circ} \mathrm{W}$ & $57^{\circ} \mathrm{SW}$. \\
\hline & ............... & & ㅅ… & 90 & & N. $84^{\circ} \mathrm{E}$ & $70^{\circ} \mathrm{SE}$ \\
\hline \multirow[t]{2}{*}{127} & Ruby Red ............................ & 3 & Northwest vein .................... & 12 & .02 & N. $70^{\circ} \mathrm{W}$. & $50^{\circ} \mathrm{SW}$. \\
\hline & & & $\begin{array}{l}\text { Northeast vein } \\
\text { East vein }\end{array}$ & 110 & $.3-.6$ & $\mathrm{~N} .86^{\circ} \mathrm{E}$ & n.d. \\
\hline \multirow[t]{3}{*}{128} & & 3 & & 10 & 1.7 & N.56 $\mathrm{W}$. & $55^{\circ} \mathrm{SW}$. \\
\hline & ………............ & 3 & $\begin{array}{l}\text { Northeast vein } \\
\text { Central vein }\end{array}$ & n.d. & 1.5 & n.d. & n.d. \\
\hline & & & 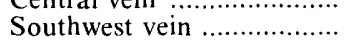 & $\begin{array}{l}\text { n.d. } \\
\text { n.d. }\end{array}$ & .5 & $\begin{array}{l}\text { n.d. } \\
\text { n.d. }\end{array}$ & $\begin{array}{l}\text { n.d. } \\
\text { n.d. }\end{array}$ \\
\hline 129 & & 1 & 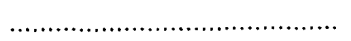 & 15 & $.6-1.2$ & N. $55^{\circ} \mathrm{W}$. & n.d. \\
\hline 130 & $\begin{array}{l}\text { Spring Canyon Nos. } 1 \\
\text { and } 2 \text {. }\end{array}$ & 1 & 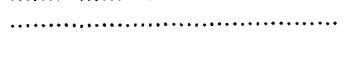 & 10 & .7 & N. $2^{\circ} \mathrm{E}$ & n.d. \\
\hline 131 & Lookout No. 1 & 1 & 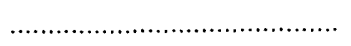 & 50 & $1.6-1.8$ & $\mathrm{~N} .17^{\circ} \mathrm{W}$ & Steep. \\
\hline 132 & Sauser No. I ……................. & 1 & 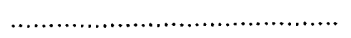 & 155 & $.2-.7$ & N. $34^{\circ} \mathrm{W}$ & $90^{\circ}$ \\
\hline 133 & Welco No. 7 ......................... & 1 & 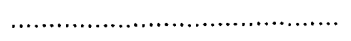 & 27 & $.08-1.7$ & N. $40^{\circ} \mathrm{E}$. & $20^{\circ} \mathrm{SE}$ \\
\hline 134 & 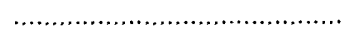 & 1 & 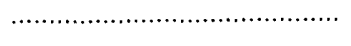 & n.d. & n.d. & n.d. & n.d. \\
\hline \multirow[t]{3}{*}{135} & & 3 & North vein & 6 & $.2-.3$ & N. $77^{\circ} \mathrm{W}$ & n.d. \\
\hline & & & Central vein ......................... & 150 & .6 & $\mathrm{~N} .77^{\circ} \mathrm{W}$ & $82^{\circ} \mathrm{SW}$. \\
\hline & & & 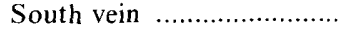 & 200 & 1.5 & N. $57^{\circ} \mathrm{W}$ & $72^{\circ} \mathrm{SW}$ \\
\hline 136 & Apex & 1 & 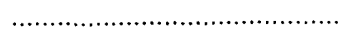 & 135 & $1.5-3$ & $\mathrm{~N} .75^{\circ} \mathrm{W}$ & $55^{\circ}-60^{\circ} \mathrm{NE}$ \\
\hline 137 & Red Hill No. 1 ....................... & 1 & 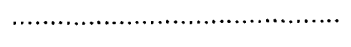 & n.d. & $1-1.8$ & N. $40^{\circ} \mathrm{W}$ & $19^{\circ} \mathrm{NE}$ \\
\hline \multirow{6}{*}{$\begin{array}{l}138 \\
139 \\
140 \\
141 \\
142\end{array}$} & 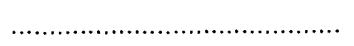 & 1 & 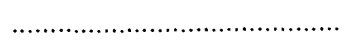 & 75 & .7 & $\mathrm{~N} .84^{\circ} \mathrm{W}$. & n.d. \\
\hline & 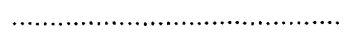 & 1 & 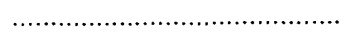 & n.d. & n.d. & N. $19^{\circ} \mathrm{E}$ & n.d. \\
\hline & ............ & 1 & 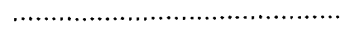 & 60 & $.2-.4$ & N.75 $\mathrm{E}$. & $55^{\circ} \mathrm{SE}$ \\
\hline & Silver Queen No. 9 ........... & 1 & 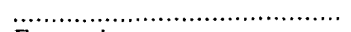 & n.d. & .2 & N. $55^{\circ} \mathrm{W}$. & $31^{\circ} \mathrm{SW}$ \\
\hline & 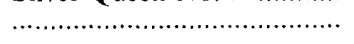 & 2 & 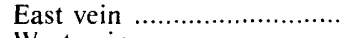 & n.d. & n.d. & n.d. & n.d. \\
\hline & & & 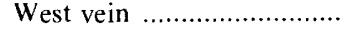 & 75 & 25 & n.d. & n.d. \\
\hline \multirow{3}{*}{$\begin{array}{l}143 \\
144 \\
145\end{array}$} & Silver Queen No. 2 & 1 & 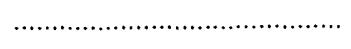 & 45 & $.2-.3$ & N. $55^{\circ} \mathrm{W}$. & $72^{\circ} \mathrm{SW}$. \\
\hline & I........................... & 1 & & n.d. & n.d. & n.d. & n.d. \\
\hline & Lone Star No. 2 & 2 & $\begin{array}{l}\text { North vein } \\
\text { South vein }\end{array}$ & $\begin{array}{l}268 \\
555\end{array}$ & $\begin{array}{l}1.5-3 \\
10-31.5\end{array}$ & $\begin{array}{c}\text { N. } 75^{\circ} \mathrm{W} \\
\text { N. } 75^{\circ} \text { E.-N. } 75^{\circ} \mathrm{W} .\end{array}$ & $\begin{array}{l}45^{\circ}-65^{\circ} \mathrm{SW} \\
75^{\circ}-80^{\circ} \mathrm{N}\end{array}$ \\
\hline \multirow{4}{*}{146} & Silver Queen 52B ............... & 4 & & & & N. $80^{\circ} \mathrm{W}$. & $34^{\circ}-55^{\circ} \mathrm{SW}$ \\
\hline & & & South-central vein .................. & 125 & $.7-2$ & N. $80^{\circ} \mathrm{W}$. & $55^{\circ} \mathrm{SW}$ \\
\hline & & & North-central vein ............... & 40 & $.5-2$ & N. $80^{\circ} \mathrm{W}$ & n.d. \\
\hline & & & North vein ............................. & 2,080 & $2-28$ & N. $85^{\circ} \mathrm{E}$ & Steep. \\
\hline 147 & . & I & 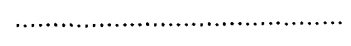 & n.d. & n.d. & N. $80^{\circ} \mathrm{E}$ & n.d. \\
\hline \multirow[t]{2}{*}{148} & Silver Queen 38A ................ & 2 & 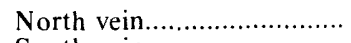 & 32 & 31 & N. $85^{\circ} \mathrm{E}$. & $60^{\circ} \mathrm{NW}$. \\
\hline & & & South vein & 210 & $2-4.5$ & $\mathrm{~N} .85^{\circ} \mathrm{E}$ & $60^{\circ} \mathrm{NW}$ \\
\hline \multirow{3}{*}{$\begin{array}{l}149 \\
150 \\
151\end{array}$} & Idaho No. 3 ............................ & 1 & . & 40 & $.1-.7$ & N. $46^{\circ} \mathrm{W}$. & n.d. \\
\hline & lola & 1 & . & 50 & $5-12$ & $\begin{array}{l}N .70^{\circ} \mathrm{W} \\
\mathrm{V}\end{array}$ & $40^{\circ} \mathrm{SW}$. \\
\hline & & & & J0 & $.5-1.2$ & N. $50^{\circ} \mathrm{W}$ & $50^{\circ} \mathrm{SW}$ \\
\hline \multirow[t]{3}{*}{152} & lola & 3 & North vein & 500 & .7 & $\mathrm{~N} .88^{\circ} \mathrm{E}$ & $60^{\circ} \mathrm{NW}$. \\
\hline & & & Central vein & 2,100 & 1 & $\mathrm{~N} .85^{\circ} \mathrm{E}$. & n.d. \\
\hline & & & South vein & 510 & n.d. & $\mathrm{N} .83^{\circ} \mathrm{E}$. & n.d. \\
\hline \multirow{2}{*}{153} & Nellie B …............................. & 2 & North vein & $\begin{array}{r}120 \\
10\end{array}$ & $\begin{array}{l}.3-1.5 \\
2.5\end{array}$ & $\begin{array}{l}\mathrm{N} .75^{\circ} \mathrm{W} \\
\mathrm{N} 82^{\circ} \mathrm{W}\end{array}$ & $70^{\circ} \mathrm{SW}$. \\
\hline & & & 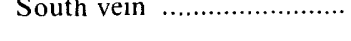 & 10 & 2.5 & N.82 W. & n.d. \\
\hline 154 & Silver Queen No. 49 ........... & 1 & 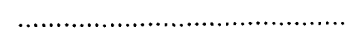 & n.d. & n.d. & n.d. & n.d. \\
\hline 155 & Silver Queen No. 49A ........ & 1 & 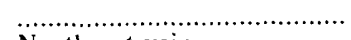 & 10 & .5 & N. $50^{\circ} \mathrm{W}$. & $38^{\circ} \mathrm{SW}$ \\
\hline \multirow[t]{2}{*}{156} & Silver Queen No. 47C ....... & 2 & Northeast vein ...................... & 300 & n.d. & N. $53^{\circ} \mathrm{W}$ & n.d. \\
\hline & & & Southwest vein ....................... & 300 & n.d. & $\mathrm{N} .53^{\circ} \mathrm{W}$ & n.d. \\
\hline
\end{tabular}


TABI.E 2.-Dimensions and attitude of thorium veins in the Lemhi Pass area-Continued

\begin{tabular}{|c|c|c|c|c|c|c|c|}
\hline $\begin{array}{l}\text { Locality } \\
\text { No. (pl. I) }\end{array}$ & $\begin{array}{l}\text { Name of claim or vein. } \\
\text { where known }\end{array}$ & $\begin{array}{l}\text { Number } \\
\text { of veins }\end{array}$ & $\begin{array}{l}\text { Veins, it more than one } \\
\text { or branched }\end{array}$ & $\begin{array}{l}\text { Exposed } \\
\text { length (ft) }\end{array}$ & $\begin{array}{l}\text { Thickness } \\
\text { (ft) }\end{array}$ & Strike & Dip \\
\hline $\begin{array}{l}158 \\
159\end{array}$ & , & $\begin{array}{l}1 \\
1\end{array}$ & 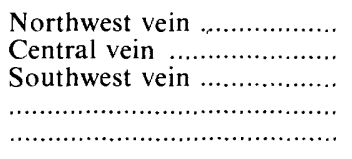 & $\begin{array}{r}32 \\
50 \\
50 \\
\text { n.d. } \\
10\end{array}$ & $\begin{array}{c}.5 \\
.8 \\
.2-.3 \\
.4 \\
.1-.2\end{array}$ & $\begin{array}{l}\text { N. } 77^{\circ} \mathrm{W} . \\
\text { N. } 60^{\circ} \mathrm{W} . \\
\text { N. } 75^{\circ} \mathrm{W} . \\
\text { n.d. } \\
\text { N. } 70^{\circ} \mathrm{E} .\end{array}$ & $\begin{array}{l}\text { n.d. } \\
\text { n.d. } \\
\text { n.d. } \\
\text { n.d. } \\
70^{\circ} \mathrm{NW} .\end{array}$ \\
\hline $\begin{array}{l}160 \\
161 \\
162 \\
163 \\
164\end{array}$ & $\begin{array}{l}\text { Pine Nos. } 1 \text { and } 2 \text {............ } \\
\text { Black Bear No. } 1 \text {............... }\end{array}$ & $\begin{array}{l}1 \\
1 \\
1 \\
1 \\
2\end{array}$ & $\begin{array}{l}\text { Northwest-trending vein } \\
\text { Northeast-trending vein }\end{array}$ & $\begin{array}{r}25 \\
\text { n.d. } \\
12 \\
50 \\
20 \\
10\end{array}$ & $\begin{array}{l}.5 \\
1+ \\
.9 \\
3.5 \\
.7 \\
.4\end{array}$ & $\begin{array}{l}\text { N. } 80^{\circ} \mathrm{W} \text {. } \\
\text { n.d. } \\
\text { N. } 30^{\circ} \mathrm{W} . \\
\text { N. } 72^{\circ} \mathrm{W} \text {. } \\
\text { N. } 32^{\circ} \mathrm{W} \text {. } \\
\text { N. } 84^{\circ} \mathrm{E} .\end{array}$ & $\begin{array}{l}\text { n.d. } \\
\text { n.d. } \\
\text { n.d. } \\
\text { n.d. } \\
62^{\circ} \mathrm{SW} \text {. } \\
58^{\circ} \mathrm{SE} \text {. }\end{array}$ \\
\hline 165 & Black Rock ........................... & 2 & Northwest-trending vein $\ldots$ & 330 & $1-2.5$ & 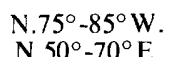 & $55^{\circ}-75^{\circ} \mathrm{SW}$ \\
\hline $\begin{array}{l}166 \\
167 \\
168\end{array}$ & Scott & $\begin{array}{l}1 \\
1 \\
1\end{array}$ & (1) & $\begin{array}{r}600 \\
7 \\
\text { n.d. }\end{array}$ & $\begin{array}{l}.2-2 \\
.2-.3 \\
\text { n.d. }\end{array}$ & $\begin{array}{l}\text { N. } 68^{\circ}-85^{\circ} \mathrm{E} \\
\text { N. } 50^{\circ} \mathrm{W} \\
\text { n.d. }\end{array}$ & $\begin{array}{l}60^{\circ} \mathrm{SE} . \\
40^{\circ} \mathrm{SW} \\
\text { n.d. }\end{array}$ \\
\hline $\begin{array}{l}169 \\
170 \\
172 \\
173 \\
174\end{array}$ & $\begin{array}{l}\text { Katy } \\
\text { Chief Tendoy No. } 1 \text {.......... } \\
\text { Barbara }\end{array}$ & $\begin{array}{l}1 \\
1 \\
1 \\
1 \\
1\end{array}$ & , & $\begin{array}{r}20 \\
110 \\
150 \\
\text { n.d. } \\
180\end{array}$ & $\begin{array}{l}.7 \\
\text { n.d. } \\
1.8-4 \\
\text { n.d. } \\
\text { n.d. }\end{array}$ & $\begin{array}{l}\text { N. } 35^{\circ} \mathrm{W} . \\
\text { N. } 16^{\circ} \mathrm{W} . \\
\text { N. } 51^{\circ} \mathrm{E} . \\
\text { n.d. } \\
\text { N. } 40^{\circ} \mathrm{W} .\end{array}$ & $\begin{array}{l}\text { n.d. } \\
\text { n.d. } \\
14^{\circ} \mathrm{NW} . \\
\text { n.d. } \\
\text { n.d. }\end{array}$ \\
\hline $\begin{array}{l}175 \\
176\end{array}$ & Ellis & $\frac{1}{2}$ & $\begin{array}{l}\text { Northeast-trending vein .... } \\
\text { Northwest-trending vein } \ldots\end{array}$ & $\begin{array}{r}\text { n.d. } \\
50 \\
4\end{array}$ & $\begin{array}{l}\text { n.d. } \\
\text { n.d. } \\
.05\end{array}$ & $\begin{array}{l}\text { n.d. } \\
\text { N. } 80^{\circ} \mathrm{E} \text {. } \\
\text { N. } 63^{\circ} \mathrm{W} \text {. }\end{array}$ & $\begin{array}{l}\text { n.d. } \\
\text { n.d. } \\
54^{\circ} \mathrm{SW} \text {. }\end{array}$ \\
\hline $\begin{array}{l}177 \\
178\end{array}$ & $\begin{array}{l}\text { Elkhorn No. } 5 \\
\text { Elkhorn No. } 1\end{array}$ & 1 & 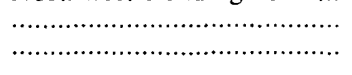 & $\begin{array}{r}60 \\
750\end{array}$ & $\begin{array}{c}.4 \\
.9-1.5\end{array}$ & $\begin{array}{l}\text { N.82 } 2^{\circ} \mathrm{W} \\
\text { N. } 65^{\circ} \mathrm{W}\end{array}$ & $\begin{array}{l}\text { Steep SE. } \\
78^{\circ} \mathrm{NE}\end{array}$ \\
\hline $\begin{array}{l}179 \\
180 \\
181 \\
185 \\
186\end{array}$ & $\begin{array}{l}\text { Viola No. } 4 \ldots \ldots \\
\text { Viola } \ldots \ldots \ldots \ldots \ldots \ldots \ldots \ldots \ldots \ldots \ldots\end{array}$ & $\begin{array}{l}1 \\
1 \\
1 \\
1 \\
1\end{array}$ & , & $\begin{array}{r}105 \\
50 \\
150 \\
1.550 \\
\text { n.d. }\end{array}$ & $\begin{array}{l}1.5+ \\
1.7 \\
1.1 \\
\text { n.d. } \\
\text { n.d. }\end{array}$ & $\begin{array}{l}\text { N. } 30^{\circ} \mathrm{E} \text {. } \\
\text { N. } 58^{\circ} \mathrm{W} \text {. } \\
\text { N. } 70^{\circ} \mathrm{W} \text {. } \\
\text { N. } 38^{\circ} \mathrm{W} \text {. } \\
\text { n.d. }\end{array}$ & $\begin{array}{l}35^{\circ} \mathrm{NW} . \\
\text { n.d. } \\
56^{\circ} \mathrm{NE} . \\
\text { n.d. } \\
\text { n.d. }\end{array}$ \\
\hline $\begin{array}{l}187 \\
188 \\
189 \\
190\end{array}$ & $\begin{array}{l}\text { Mornell } \\
\text { Thor No. } 7 \text {.................... } \\
\text { Thor Nos. } 1 \text { and } 2\end{array}$ & $\begin{array}{l}1 \\
1 \\
1 \\
2\end{array}$ & 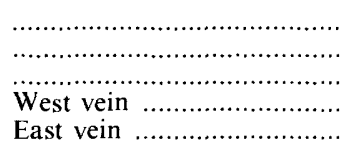 & $\begin{array}{l}220 \\
\text { n.d. } \\
\text { n.d. } \\
150 \\
150\end{array}$ & $\begin{array}{l}.2-9 \\
\text { n.d. } \\
\text { n.d. } \\
\text { n.d. } \\
.9\end{array}$ & $\begin{array}{l}\text { N.83 } \mathrm{W} . \\
\text { n.d. } \\
\text { n.d. } \\
\text { N.-S. } \\
\text { N. } 55^{\circ} \mathrm{W} .\end{array}$ & $\begin{array}{l}68^{\circ} \mathrm{NE} . \\
\text { n.d. } \\
\text { n.d. } \\
\text { n.d. } \\
20^{\circ} \mathrm{SW} .\end{array}$ \\
\hline $\begin{array}{l}191 \\
192\end{array}$ & $\mathrm{ThO}_{2}$ & $\begin{array}{l}2 \\
2\end{array}$ & 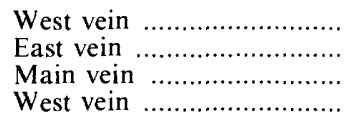 & $\begin{array}{r}\text { n.d. } \\
\text { n.d. } \\
2,860 \\
740\end{array}$ & $\begin{array}{l}\text { n.d. } \\
\text { n.d. } \\
1-15 \\
1-1.3\end{array}$ & $\begin{array}{l}\text { n.d. } \\
\text { n.d. } \\
\text { N. } 28^{\circ} \mathrm{W} \text {. } \\
\text { N. } 25^{\circ} \mathrm{W} \text {. }\end{array}$ & $\begin{array}{l}\text { n.d. } \\
\text { n.d. } \\
32^{\circ} \text { NE. }-90^{\circ} \\
\text { Steep. }\end{array}$ \\
\hline
\end{tabular}

Fifteen veins are more than 1,000 feet long. These veins are the Shear Zone (loc. 73), Last Chance (loc. 82), main vein at the $\mathrm{ThO}_{2}$ (loc. 192), Cago No. 12 (loc. 49), central vein at the Iola (loc. 152), north vein of the Silver Queen 52B, Contact (loc. 52), northwest-trending vein on the Black Rock (Montana) property (loc. 75), north vein on the G\&G Nos. 1, 2, and 5 claims (loc. 90), Viola (loc. 185), Lucky Horseshoe (loc. 1), vein on G\&G Nos. 6 and 8 claims (loc. 89), northeast vein on Reactor (loc. 107), principal vein on Deer Fraction 1A (loc. 21), and southeast vein on the Frying Pan (loc. 85). The first six veins of the above group have been traced for more than 2,000 feet. Further exploration will probably extend the known length of several other veins to more than 1,000 feet.
The thorium veins vary considerably in thickness and range from thin seams to 40 feet thick (table 2). Although some veins pinch and swell abruptly, many are fairly uniform for most of their length, changes in thickness being most common near the ends of the vein. The northwest-trending vein on the Black Rock (Idaho) property (loc. 165) is 1-2.5 feet thick in the 330 feet of its exposed length. The most thorium-rich part of the Cago No. 12 (loc. 49) is about 690 feet long, and the thickness of this part of the bein is 10-16 feet. The northern vein on the Dan Patch Nos. 1 and 2 claims (loc. 98) is 2-2.5 feet thick along its entire known length of 508 feet. The 1,300-foot-long northeast vein on the Reactor property (loc. 107) varies in thickness from 0.8 to 5.0 feet, but the thickness of at least 975 feet of its strike length ranges 
only from 1.5 to 2.0 feet. The maximum thickness of 63 percent of the veins in the district is 1 foot or greater and for 6 percent ( 16 veins) it is more than 10 feet.

The thorium deposits seem to persist at depth. They are found at elevations ranging from 5,240 to 9,430 feet. The Last Chance vein is exposed on the surface over an elevation difference of about 520 feet. The west adit cuts this vein approximately 160 feet below the surface; the vein is approximately the same thickness in the adit as on the surface. This vein has also been cut in drill holes at least 300 feet below the surface. The northeast vein on the Reactor property (loc. 107) is exposed for 360 feet vertically. Another vein having a large vertical exposure is the central vein on the Iola property (loc. 152), which has been traced intermittently for a vertical distance of about 560 feet.

The attitude of the thorium veins in the 155-square-mile Lemhi Pass district is remarkably similar. A list of all known strikes and dips is compiled in table 2 . Most veins have a northwest strike, and the greater part of these strike either $\mathrm{N}$. $40^{\circ}-60^{\circ} \mathrm{W}$. or $\mathrm{N} .70^{\circ}-80^{\circ} \mathrm{W}$. (fig. 15 ). A few, however, show radical departures, and almost every direction, except due north, has been seen. Veins having divergent strike may occupy fractures in the same general area as those having the normal northwest strike. A short vein having a N. $75^{\circ} \mathrm{E}$. strike occurs on the Black Rock (Montana) property (loc. 75 ) adjacent to a much larger vein having a $N .47^{\circ} \mathrm{W}$. strike. Similarly, at locality 55 two veins are found: One having a strike of $\mathrm{N} .30^{\circ} \mathrm{E}$., the other having a strike of $\mathrm{N} .39^{\circ} \mathrm{W}$. The strike of individual veins commonly varies, as they were intruded along irregular fractures. Five measurements made along the 1,940-foot Contact vein (loc. 52) from east to west show the following variations in strike: (1) N. $70^{\circ} \mathrm{W}$., (2) N. $55^{\circ}$ W., (3) N. $72^{\circ}$ W., (4) east-west, and (5) N. $70^{\circ}$ E. Some veins branch, such as the Lucky Horseshoe (loc. 1), the main part of the vein striking $\mathrm{N} .70^{\circ} \mathrm{W}$. and the largest branch striking about N. $80^{\circ}$ E. the Black Bull No. 3 also branches, the main part having a strike of $\mathrm{N} .77^{\circ} \mathrm{W}$. and the smaller part a strike of $\mathrm{N} .77^{\circ} \mathrm{E}$.

Most of the veins dip steeply to the south (fig. 15), and 43 percent of them dip between $50^{\circ}$ and $80^{\circ} \mathrm{S}$. The dips of the rest are scattered over a wide range of values both to the north and to the south. None of the dips, however, were less than $10^{\circ}$ and only 15 percent of the veins have dips of less than $40^{\circ}$. South, as noted, is the predominant direction of dip; 73 veins dip to the south ( 65 percent) and 32 veins dip to the north $(28$ percent). Eight of the measured veins (7 percent) have a vertical dip. Dips, like strikes, also show considerable variation along the same vein. Dips on the long Last Chance vein range from $40^{\circ}$ to $70^{\circ} \mathrm{S}$.; four dips measured in the east adit (fig. 30) vary from $43^{\circ}$ to $70^{\circ} \mathrm{S}$. The Reactor vein (loc. 107), where it is exposed in several places, dips $70^{\circ}-85^{\circ} \mathrm{S}$. The south vein on the Silver Queen 52B property (loc. 146) dips $34^{\circ}-55^{\circ} \mathrm{S}$., and the northwest-trending vein on the Black Rock (Idaho) property (loc. 165) dips $55^{\circ}-75^{\circ} \mathrm{SW}$.

\section{RELATION OF VEINS TO STRUCTURAL FEATURES}

Most thorium veins are found along small faults and fractures that are related to faulting of Tertiary age. As previously noted, the veins commonly occur in shear zones which may be as much as 50 feet wide. Rocks in thse zones commonly are thoroughly granulated and are stained with iron oxides. Not only did the movement along these fracture zones start before the veins were introduced, but it also continued during and after the introduction of the veins. A common feature of almost all veins is their brecciated character (fig. $16 A, B$, and $C$ ). The granulation of veins during formation is noted where the first minerals to form-generally quartz and microcline-are brecciated, and the fractures are filled by minerals (fig. 16C) such as iron oxide minerals, sericite, barite, and thorite, which are in turn brecciated by later movement. Several generations of quartz and feldspar may occur, and at the Last Chance and Chief Tendoy No. 3 and No. 4 claims (locs. 115 and 116) veinlets of later quartz and microcline cut earlier formed microcline and quartz (fig. 16C). Quartz, in addition to being granulated, shows stress by the presenc eof strain shadows and sutured borders. Slickensiding is a common feature on the sides of veins and along fractures within many veins. Fracturing is predominantly parallel to the sides of veins.

Although the amount of movement on fractures in which the thorium veins occur is difficult to estimate, most show little measureable movement. In only two places are veins found on faults where substantial offset can be shown. These two places are at localities 149 and 150 . At locality 149 a 1-8-inch-thick vein lies in the gouge of the large Lemhi Pass fault zone. At locality 150 a 1 -foot-thick vein that can be traced for 15 feet occurs in the gouge of the Pattee Creek fault zone (fig. 14C).

Although most of the vein-bearing fractures show little movement, these fractures are related to the major faulting. The greater part of the veins in the Lemhi Pass district are less than 1 mile from either one of the large faults or from smaller cross faults (pl. 1). The greatest concentration of veins is in the northeastern part of the district, where the large Lemhi Pass, Bull Moose, and Dan Patch faults either intersect or approach one another. A second group of veins, in the northern part of the area, occurs near Pattee Creek, where most are either close to the Pattee Creek fault or close to one of several smaller faults. Several veins lie adjacent to cross faults that offset the east side of the Yearian Creek graben. These include the Mornell vein (loc. 187), which is adjacent to a fault along the upper part of Yearian Creek, and seven veins, including the $\mathrm{ThO}_{2}$ vein, at localities 110 , 190, 191, and 192, which are adjacent to a fault 3 miles farther south. Most of the veins that are not close to faults are short and thin.

The strike of the veins in the northeast part of the district may be parallel, at a fairly acute angle, or at a more obtuse angle to the long Tertiary faults; the strike of veins in other 

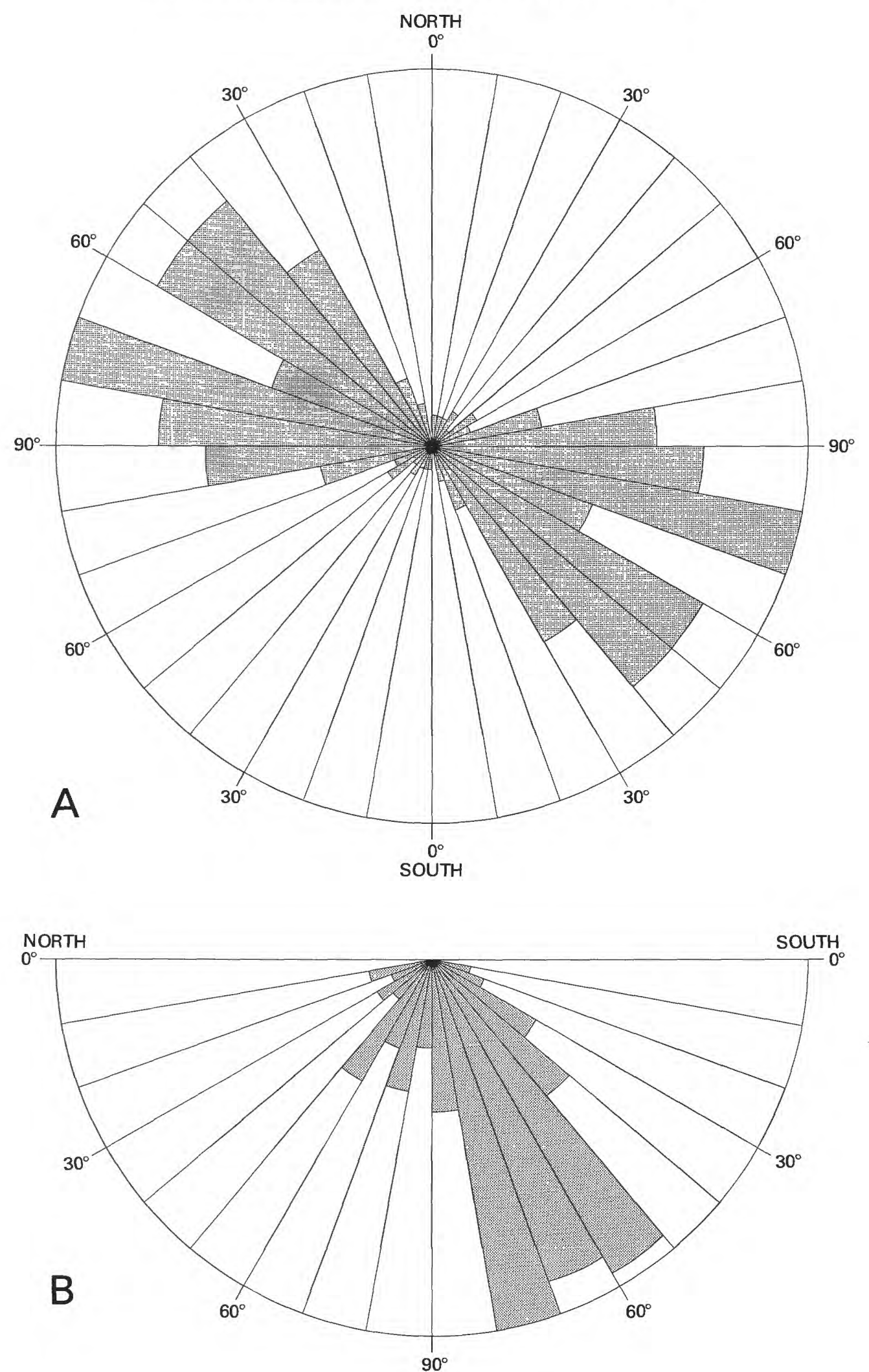

Figure 15.-Attitudes of thorium veins in the Lemhi Pass district. $A$, Strike diagram of 182 veins. $B$, Dip diagram of 113 veins. 


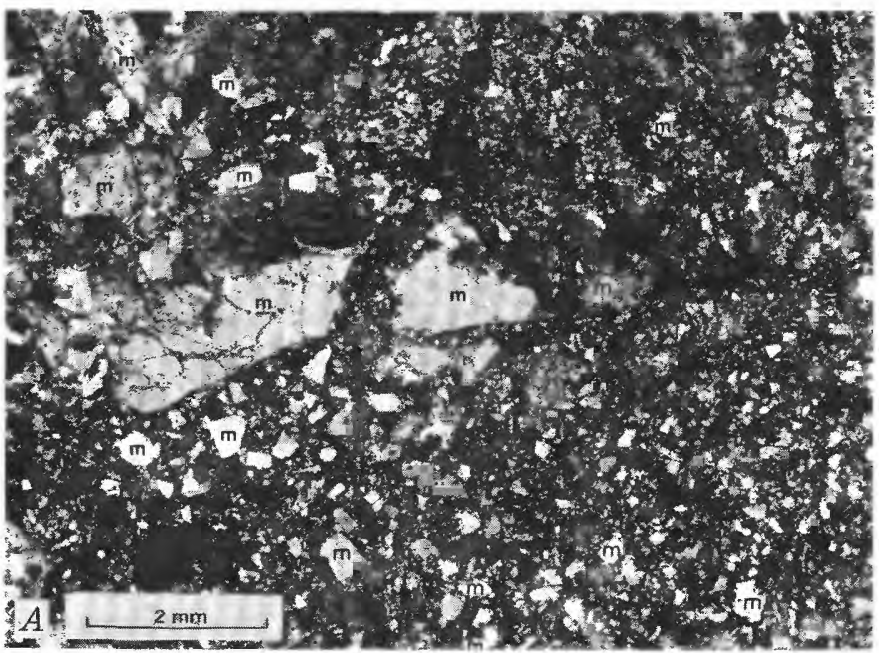

Figure 16. - Brecciated and granulated vein material shown under crossed nicols. Photographs by L. S. Hendricks. A, Last Chance vein (loc. 82). Fine granulated quartz and microcline with large pieces of microcline $(\mathrm{m})$. Black veinlets are of limonite. $B$. Angular fragments of quartzite wall rock ( $w r$ ) surrounded by partly granulated quartz in a vein from the Chief Tendoy No. 3 property (loc. 116$)$. Hematite $(h)$ rims small pieces of quartzite on right side of picture. $C$, Large crystals of microcline $(\mathrm{m})$ and limonite (black) cut by later veinlets of feldspar and quartz showing two periods of mineralization in the Last Chance vein (loc. 82).

areas is generally at an obtuse angle to the neighboring faults. Veins parallel to the large faults, as the Lucky Horseshoe (loc. 1) is parallel to the Lemhi Pass fault, and the Black Rock (loc. 25), Bull Moose (loc. 76), Frying Pan (loc. 85), G\&G Nos. 6 and 8 (loc. 89), G\&G Nos. 1, 2, and 5 (loc. 90 ), and Reactor (loc. 107) veins are parallel to either the Bull Moose or Dan Patch faults, are probably formed on small subsidiary breaks. Veins formed in fractures at small angles to the faults are mainly formed in tight shears. These veins tend to be thin and commonly are multiple. The largest shear zone occupied by veins contains 22 vein localities and extends for 2.7 miles from the ridge top northwest of the Cago No. 12 (loc. 49) to South Frying Pan Creek (pl. 1). In addition to the Cago No. 12, this zone also contains such well-known localities as the Contact (loc. 52), Beaverhead (loc. 64), Trapper No. 1 (loc. 67), and the Shear Zone (loc. 73). The Shear Zone vein is in turn not one but a series of closely spaced en echelon and branching veins that can be traced for about 6,000 feet. The rocks along this zone are all highly sheared and stained with iron oxides. Veins which form at a more obtuse angle to the faults are mainly in tension fractures formed by shear movement along the faults. These veins occur in fairly open fractures and tend to be thick. Veins of this type in the northeast part of the district include the Wonder (loc. 45), H.R.S. No. 1 (loc. 95), and the Dan Patch Nos. 1 and 2 (loc. 98). Veins of this type in other parts of the area include localities 135 and 138, Elkhorn (loc. 108), Thor Nos. 1 and 2 (loc. 190), and $\mathrm{ThO}_{2}$ (loc. 192).
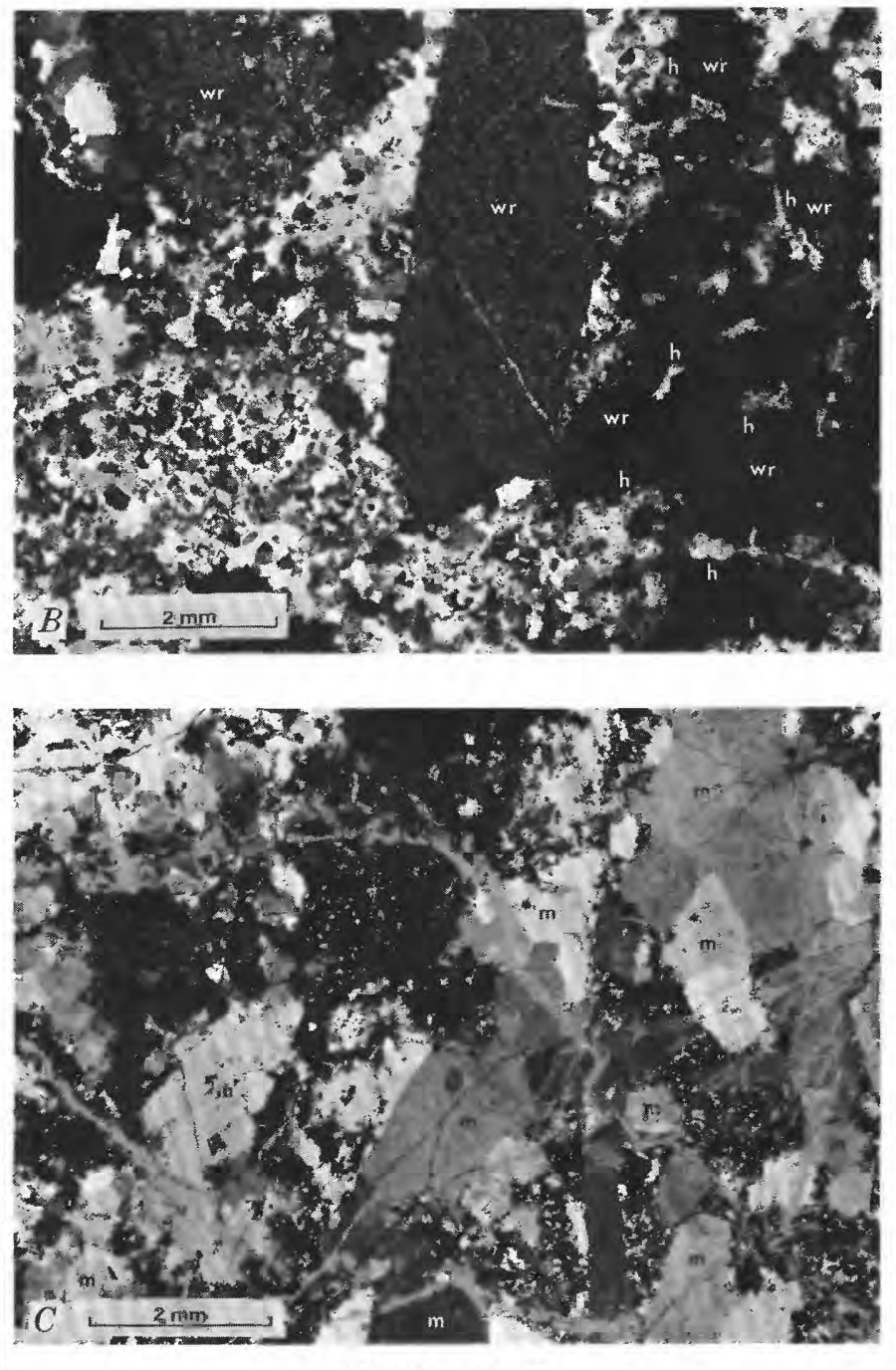

MINERALOGY

Forty-five minerals were found in a detailed examination of 160 samples from the veins in the Lemhi Pass district. Many of these minerals are rare, and only 14 minerals were found in at least 10 percent of the samples (table 3 ). In spite of the bewildering number of minerals, the basic mineralogy of the veins is fairly simple. The veins consist primarily of a quartz of microcline gangue cut by numerous irregular limonite or hematite veinlets and masses that contain thorium minerals and small amounts of various accessory minerals. Although many minerals occur repeatedly in various parts of the veins, only a few of the minerals make up as much as 10 percent of any sample. In addition to quartz, microcline, hematite, and limonite, other minerals that make up this amount of any sample are thorite, barite, calcite, and siderite. Thorite and barite make up more than 10 percent of the Shear Zone vein (loc. 73) in a few places. Calcite is the chief gangue mineral in seven veins, including the Black Bull No. 3 (loc. 20) and the Wonder (loc. 45) veins. Siderite occurs in substantial amounts in parts of the Wonder vein, one of only two veins in which it was recognized in the district. 
TABLE 3.- Occurrence of minerals in 160 samples from 92 different thorium veins in the Lemhi Pass district

\begin{tabular}{|c|c|c|}
\hline \multirow{2}{*}{ Minerals } & \multicolumn{2}{|c|}{ Samples in which mineral was observed } \\
\hline & Number & Percent \\
\hline \multicolumn{3}{|l|}{ Principal gangue minerals: } \\
\hline $\begin{array}{l}\text { Quartz } \\
\text { Microcline .............. }\end{array}$ & 160 & 100 \\
\hline \multicolumn{3}{|l|}{ Other gangue minerals: } \\
\hline Barite ..................... & 64 & 40.0 \\
\hline Calcite & 39 & 24.4 \\
\hline 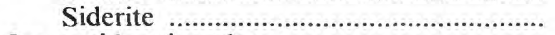 & 4 & 2.5 \\
\hline \multicolumn{3}{|l|}{ Iron oxide minerals: } \\
\hline Limonite ............ & 136 & 85.0 \\
\hline 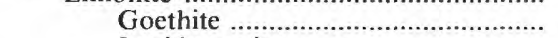 & 55 & 34.4 \\
\hline 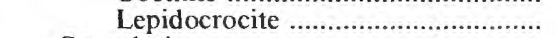 & 2 & 1.3 \\
\hline 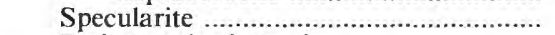 & $13 \overline{3}$ & 83.1 \\
\hline Red granular hematite .......................... & 45 & 28.1 \\
\hline 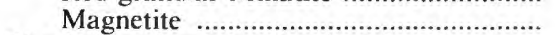 & 147 & 91.9 \\
\hline \multicolumn{3}{|l|}{ Thorium and rare-earth minerals: } \\
\hline Thorite & 110 & 68.8 \\
\hline 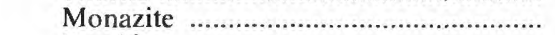 & 37 & 23.1 \\
\hline 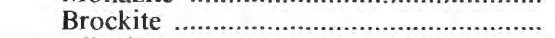 & 11 & 6.9 \\
\hline 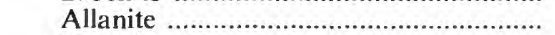 & 4 & 2.5 \\
\hline Xenotime & 4 & 2.5 \\
\hline 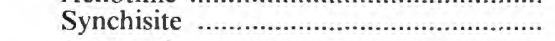 & 3 & 1.9 \\
\hline 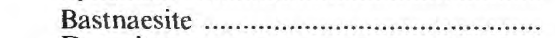 & 1 & .6 \\
\hline 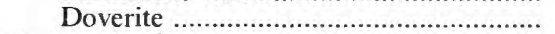 & i & .6 \\
\hline \multicolumn{3}{|l|}{ Accessory minerals: } \\
\hline Rutile .................... & 94 & 58.7 \\
\hline 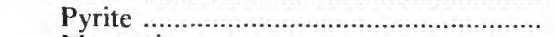 & 42 & 26.3 \\
\hline 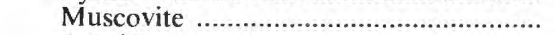 & 42 & 26.3 \\
\hline 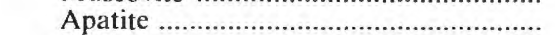 & 31 & 19.4 \\
\hline 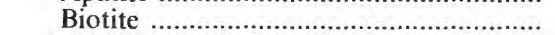 & 10 & 6.3 \\
\hline Chlorite ........... & 4 & 2.5 \\
\hline Manganese oxide ……......................... & 20 & 12.5 \\
\hline Psilomelane …..................................... & 2 & 1.3 \\
\hline Pyrolusite …….......................... & 2 & 1.3 \\
\hline 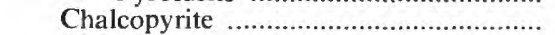 & 10 & 6.3 \\
\hline 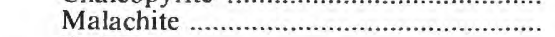 & 9 & 5.6 \\
\hline Galena & 2 & 1.3 \\
\hline 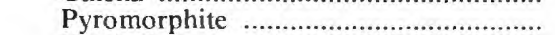 & 4 & 2.5 \\
\hline Wulfenite ……… & 3 & 1.9 \\
\hline 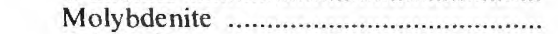 & 2 & 1.3 \\
\hline 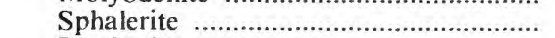 & 1 & .6 \\
\hline 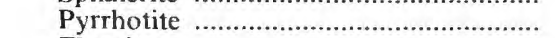 & 1 & .6 \\
\hline 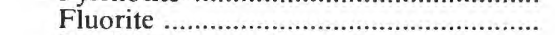 & 7 & 4.4 \\
\hline 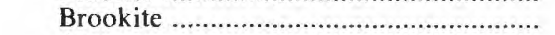 & 2 & 1.3 \\
\hline Anatase & 1 & .6 \\
\hline Jarosite ……1. & 4 & 2.5 \\
\hline 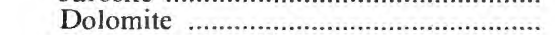 & 4 & 2.5 \\
\hline 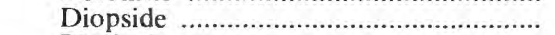 & 1 & .6 \\
\hline Plagioclase .................................... & 1 & 6 \\
\hline 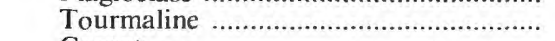 & 1 & .6 \\
\hline 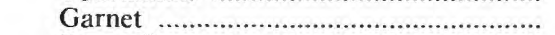 & i & .6 \\
\hline Staurolite & i & .6 \\
\hline 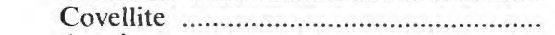 & 1 & .6 \\
\hline 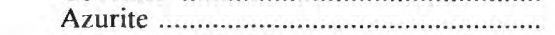 & $\mathrm{i}$ & .6 \\
\hline
\end{tabular}

Thorite, calcite, and barite, where they occur in other places, generally make up only minor amounts of the veins. Minerals such as magnetite, rutile, pyrite, monazite, muscovite, and apatite (table 3 ) are found fairly frequently in the samples examined but occur in only minor amounts in each sample. For example, magnetite is found in 92 percent and rutile in 59 percent of the samples, yet neither make up as much as 0.5 percent of any sample.

The color of the veins is due principally to limonite and hematite. Most are medium brown, but they may be reddish brown or even black depending on the amounts and type of iron oxide present. Iron oxides not only form discrete veinlets and masses but also stain and permeate many other minerals making them difficult to identify in hand specimen. The larger crystals are generally of quartz and feldspar, and they rarely exceed one-tenth of an inch in size. The original size of the other minerals is much smaller, and many thorite crystals are only $0.001-0.004$ in. across. Every vein has been granulated, and bigger fragments are commonly set in a matrix of more minute material. Small pockets of granulated material are common in many veins. The result of the staining by iron oxides, the small original grain size, and the granulation makes the identification of most minerals extremely difficult. Hence, only quartz, feldspar, hematite, limonite, manganese oxide minerals, and malachite are readily identifiable in hand specimen.

A study of the vein mineralogy was carried out using routine heavy-liquid and magnetic-separation procedures. Any mineral not readily identifiable under a binocular microscope was identified by its X-ray diffraction pattern. In a few instances spectographic analyses were used as an aid in seeking the mineral's identity.

\section{PRINCIPAL GANGUE MINERALS}

Many veins contain both quartz and microcline in abundance. A few veins, such as the Black Bull No. 2 (loc. 37) and the Pine Nos. 1 and 2 (loc. 161), are made up of more than 95 percent feldspar. Although quartz-rich and microcline-rich veins commonly occur in the same areas, a group of veins (locs. 113, 115-123) along the Continental Divide between the headwaters of Reese and Peterson Creeks are all rich in microcline. Quartz is more easily recognizable than microcline in hand specimen, as it is not as easily stained by iron oxides as the microcline, much of which is stained brown. Microcline in the veins differs somewhat in physical features from that commonly seen in igneous rocks. Under the microscope, the microcline from veins commonly is filled with fine dust-size particles probably of iron oxides. Under crossed nicols the microcline has an irregular patchy appearance. Generally it is not twinned, although a few grains showed crosshatch twinning typical of microcline. Most of the feldspar occurs in aggregates of small grains that appear in hand specimen to be large single grains. Although this mineral has a well-developed cleavage, the cleavage is not readily visible in the fine-grained aggregates.

\section{OTHER GANGUE MINERALS}

Calcite is the principal gangue mineral in only seven veins. All of these veins are small with the exception of the Wonder vein (loc. 45), which is 920 feet long. In most other veins calcite is absent or present only in trace amounts. Siderite was noted in only two veins. Carbonates, especially calcite, are common in veins in the Hall Mountain area, Idaho; Mountain Pass region, Calif.; and the Powderhorn and Wet 

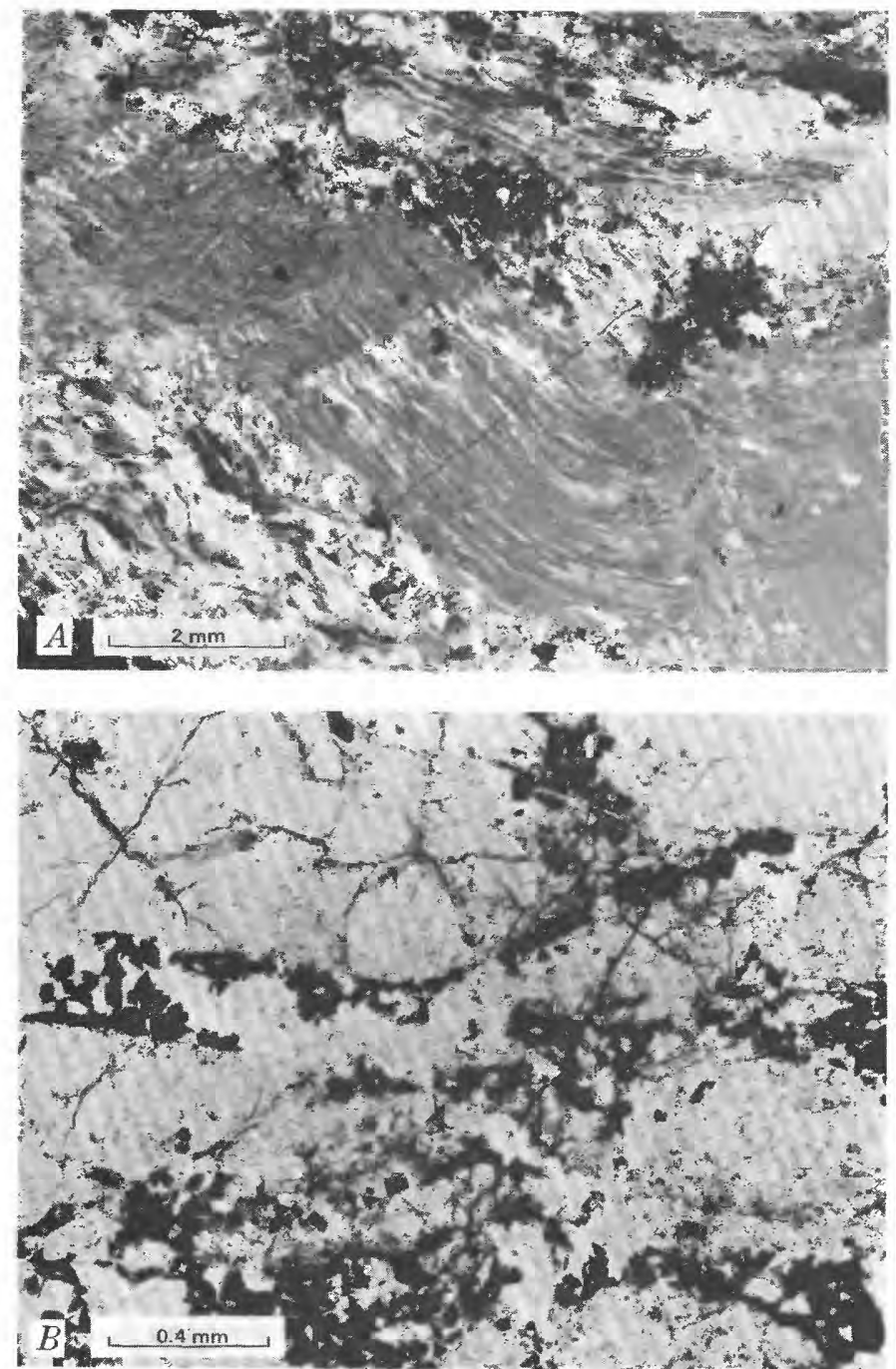

FIGURE 17.- Photomicrographs of thorium vein material. $A$, Swirled light-gray barite bounded by crushed layers of quartz and barite, from the Black Rock vein (loc. 75). Black material is goethite. Picture taken using crossed nicols. $B$, Small black thorite crystals along fractures in microcline, from the Uranium Queen vein (loc. 41). Note diamond-shaped cross sections of many of the thorite crystals. Photographs by $\mathbf{L}$. S. Hendricks.

Mountain districts, Colorado (Staatz, 1974, p. 499). Barite was found in 40 percent of the samples examined (table 3, fig. $17 \mathrm{~A}$ ). It has an erratic distribution within the veins, being fairly abundant in some parts of a vein and absent in others. In two samples taken 18 feet apart in the adit on the Shear Zone vein (loc. 73) the barite content in one is about 40 percent and in the other less than 1 percent. Barite is a common mineral in most thorium veins in the United States. This mineral is more plentiful in the thorium veins in the Wet Mountains and Powderhorn areas of Colorado and the Mountain Pass district of California than in the Lemhi Pass district.

\section{IRON OXIDE MINERALS}

Iron oxides are ubiquitous in the thorium veins; limonite and hematite make up substantial parts of many veins. The limonite varies in color and form, commonly in the same deposit. It may be dark brown, medium brown, tan, or ocherous yellow in color, have a dull to shiny surface, and a dense, granular, or vuggy texture. Limonite was visually identified in 85 percent of the samples, but in only 36 percent (57 samples) was the particular limonite mineral identified by X-ray. In most samples (55) the limonite was goethite, although in two it was identified as lepidocrocite. The lepidocrocite could not be separated from the goethite on the basis of its physical appearance. The limonite minerals commonly are associated with thorium minerals. Not only do discrete thorium minerals commonly occur in the limonitic parts of the veins, but some of the thorium apparently occurs within the limonite itself. Autoradiographs of limonite-rich parts of several veins show a bright haze of tiny gray spots over all the limonitic parts, indicating that some of the thorium occurs in this mineral either in its lattice or adsorbed on the limonite as minute crystals of some thorium mineral (Staatz, 1972, p. 65-67).

Hematite occurs with limonite in many veins, although in some it is found without limonite. Hematite occurs in two principal forms, black platy specularite and dark-red granular hematite. The former is most abundant, and tiny shiny tabular plates of this mineral a hundredth of an inch long are found in most veins. Red granular hematite is commonly associated with the specularite. It generally occurs in irregular earthy masses. Its dark-cherry-red color makes it readily identifiable in most places. Hematite is also commonly associated with thorium minerals, which it surrounds or is adjacent to in many places. Magnetite is the most common but least abundant of all the iron oxide minerals. It is found in 92 percent of the samples, but rarely does it make up more than a few tenths of 1 percent of the rocks. Magnetite is found in minute black grains, some of which are small octahedrons.

\section{THORIUM AND RARE-EARTH MINERALS}

Thorite is the predominant thorium mineral in the veins. It occurs in dark-red to reddish-brown shiny enameloid crystals that in places show conchoidal fracture. Thorite is tetragonal, and it forms crystals which have a diamond-shaped cross section (fig. 17B). In thin section thorite is light yellow to deep orange; it may be virtually isotropic or have appreciable birefringence. Thorite may occur by itself as tiny crystals along fractures in quartz or feldspar (fig. 17B), but commonly it is surrounded by limonite or hematite. In some places, as in the Last Chance vein (loc. 82), it is intergrown with monazite. Although thorite can generally be recognized under the microscope, it can also be identified by its X-ray diffraction pattern. The thorite is partly metamict, as indicated by broad, poorly defined peaks on the $\mathrm{X}$-ray diffraction pattern. The major diffraction peaks of thorite, when it is heated in air for 1 hour at $1,000^{\circ} \mathrm{C}$, become sharp and well defined; in addition, 
some minor peaks appear that were not present in the pattern of the unheated material. The composition of thorite is commonly expressed as $\mathrm{ThSiO}_{4}$, but thorium may be replaced by appreciable amounts of rare earths and the $\mathrm{SiO}_{4}$ by $\mathrm{PO}_{4}$. For example, in seven veins in which analyses indicate a high rare-earth content, thorite was the only thorium or rare-earth mineral identified. Rare earths have been found to make up as much as 20 percent of thorite in material collected from the Seerie pegmatite near Pine, Colo. (Staatz and others, 1976, p. 577), and in the seven above-mentioned samples from the Lemhi Pass district it appears to be the most likely host for these elements. Phosphorus content of several grains from three different veins was determined by G. A. Desborough using the electron microprobe (Staatz, 1972, p. 70). It varied from 0 to 10 percent and showed variation from vein to vein, grain to grain, and even within the same grain.

Monazite is the next most common thorium and rare-earth mineral, occuring in 23 percent of the samples. Although it is generally not as abundant as thorite, in seven localities (nos. 52, 61, 85, 96, 104, 126, and 169) it is considerably more abundant. In one locality (no. 86) it occurs with brockite, and in three localities (nos. 63, 106, and 113 ) it is the only throium mineral noted. At the Black Rock property (loc. 75) monazite occurs in clear shiny yellow euhedral crystals, but mainly it occurs in opaque anhedral to subhedral crystals that in color may be cream, tan, brown, orange, or yellow. Monazite is easily stained by iron oxides and some of the difference in color is due to admixtures with these minerals, but some is probably due to differences in primary composition. Differences in composition of monazite in different veins is also indicated in the X-ray diffraction pattern by shifts in position of various peaks and by differences in the relative heights of the peaks.

Brockite, a calcium thorium phosphate, is found in nine veins in the Lemhi Pass district. All are in Montana in the northeast corner of the mapped area. At four of these localities (nos. 59, 86, 89, and 90) it is the principal thorium mineral. This mineral is generally fine grained and occurs in tan, yellow, or orange anhedral crystals. Viewed through the binocular microscope, it is commonly indistinquishable from monazite or apatite. Brockite contains abnormal amounts of gadolinium, and analyses of four brockite-bearing samples showed that they were rich in this element (Staatz and others, 1972, p. 78).

Other thorium and rare-earth minerals occur in only a few veins. Allanite, which is a fairly common mineral in silicic igneous rocks, is found in only three veins. Only in parts of the Lucky Horseshoe (loc. 1) is it found in more than trace amounts. Synchisite $\left(\mathrm{CeFCO}_{3} \cdot \mathrm{CaCO}_{3}\right)$ and its yttrium analog doverite $\left(\mathrm{YFCO}_{3} \mathrm{CaCO}_{3}\right)$ are found in only three veins (locs. 136, 137, and 138); all occur in the northernmost part of the district. In two of the veins (locs. 136 and 138) synchisite is the principal rare-earth- or thorium-bearing mineral. Xenotime and bastnaesite are found in only trace amounts in four veins and one vein, respectively.

\section{ACCESSORY MINERALS}

Although 28 accessory minerals have been identified in the veins, only five accessory minerals occur in as many as 10 percent of the samples. With the exception of fluorite in one vein, and the manganese oxide minerals, all occur in only trace amounts. Rutile is the most common, being present in over half the samples examined (table 3 ). This mineral is found as tiny anhedral crystals having a greasy luster. It varies in color and may be black, dark brown, tan, light orange, or olive green. At a few localities, rutile of two different colors is present. Brookite and anatase, polymorphs of rutile, were identified in two samples and in one sample, respectively.

A few grains of pyrite are found in a little over a quarter of the samples in the Lemhi Pass district. This mineral does not make up as much as 1 percent of any sample. In many samples, however, brown cubes of limonite, a pseudomorphous replacement of the pyrite, indicate that pyrite was once much more abundant.

Muscovite also occurs in a little over a quarter of the samples. In many it is only found as a few scattered flakes, and in none is it even moderately abundant. Muscovite may also occur as small aggregates of tiny pale-green plates.

Apatite is present in sparse amounts in about a fifth of the samples. In a few veins, such as the Black Rock (loc. 75) and Atomic Blast (loc. 105), it forms discrete white to pink acicular crystals as much as $0.12 \mathrm{in}$. long. In most veins, however, it occurs in tiny white, yellow, or pink grains intergrown with other minerals. Apatite commonly occurs in the same veins with the other phosphate minerals, monazite and brockite. Small amounts of apatite are common in thorium veins in other districts and it has been reported in veins in the Hall Mountain district, Idaho, Wet Mountains and Powderhorn districts, Colorado, Laughlin Peak area, New Mexico, and Mountain Pass district, California (Staatz, 1974, p. 498).

Black amorphous manganese oxide minerals, where present, are fairly abundant. They may be intergrown with iron oxide minerals, whose color they commonly mask. They account for the black color of much of the Wonder vein (loc. 45), the main thorium vein on the Wonder No. 18 property (loc. 70), and both veins on the Black Rock property (loc. 75). The manganese oxide minerals are black to steely gray in color and are extremely fine grained. X-ray diffraction patterns of most specimens were commonly so diffuse that a particular manganese mineral could not be determined. Psilomelane was identified in two samples from the Last Chance vein (loc. 82) and pyrolusite was identified in samples from the Last Chance and from the Black Bear No. 2 (loc. 37 ) properties.

None of the other 22 accessory minerals were found in more than 6 percent of the veins, of which 18 occur in only a 
few samples. The presence of minerals containing copper, zinc, lead, and molybdenum are of special interest. Nonthorium-bearing copper veins occur in the area, and small amounts of malachite can be easily recognized in a number of thorium veins. The amount of copper minerals in various thorium veins, with the exception of the Wonder (loc. 45), is scant, and even these scant amounts are generally confined to a small part of the vein. At the Wonder vein copper minerals can be found throughout much of the vein, chalcopyrite predominating. Covellite is found in the matrix of the vein intermixed with quartz, chalcopyrite, hematite, thorite, and sphalerite (Sharp and Cavender, 1962, p. 46). Malachite and azurite coat some fracture surfaces. This vein lies only 0.75 mile south of the copper-quartz veins of the old Copper Queen mine. Sphalerite, the only zinc mineral recognized, occurs principally as transparent "grass-green" crystals in the western part of the Wonder vein.. The dark-brown iron-rich variety of sphalerite, marmatite, also was reported from this part of the vein (Sharp and Cavender, 1962, p. 46). Three lead minerals, galena, pyromorphite, and wulfenite, occur in sparse amounts in a few veins. Their presence testifies to small amounts of lead in the vein fluids, but their sparsity gives little hope of finding economically important amounts of these minerals. Molybdenum minerals are even scarcer than those of lead, and trace amounts of molybdenite were found in veins at the Daisy Nielsen ranch and at the Barbara (loc. 172), and yellow platy wulfenite at the Black Bear No. 2 (loc. 37). The source of the small amounts of these minerals need not have been the original magma from which the vein fluids were derived, but could well have been the sedimentary rocks of Precambrian age through which the vein fluids passed.

\section{CHEMICAL COMPOSITION}

The thoria content of various parts of the thorium veins in the Lemhi Pass district is known from about 420 samples. More than 350 samples have been reported on previously by Trites and Tooker (1953, p. 194, 195, 198, 201, 205), Sharp and Cavender (1962, p. 62-67), Austin (1968, p. 6-12), and Staatz (1972, table 5). Sixty-seven new thoria analyses are listed in this report. Those analyses which come from properties described in detail in the last section of this report will be found in the description of that property; those which come from properties that are not described will be found in table 4 . The samples in this district ranged in thoria content from 0.0008 to 9.4 percent. The high value was determined by wet chemical analysis from an 0.8 -foot sample collected from a vein in the Shear Zòne vein (loc. 73) (Austin, 1968, p. 6).

The thorium analyses given in this report were in part done in the U.S. Geological Survey laboratories and in part done for the U.S. Atomic Energy Commission by Lucius Pitkin, Inc. Those done in the Geological Survey laboratories include all samples with MHS numbers in this report as well as all samples done for a previous report by Staatz (1972). These analyses were done by C. A. Bunker and C. M. Bush using a gamma-ray spectrometer. The accuracy of this method is \pm 3 percent. Those done by Lucius Pitkin were done by standard wet chemical methods. Earlier analyses, such as many of those used by Trites and Tooker (1953, p. 195, 198, 201, and 205) and Sharp and Cavender (1962, p. 62-67), were done by the following three steps: (1) A measurement of total radiation, given as equivalent uranium; (2) a chemical analysis for uranium; and (3) calculation of thorium needed to account for the radiation present after subtracting radiation due to the small amount of uranium present. Although this method is based on the assumptions that the uranium present has no significant daughter products and that thorium is in equilibrium with itself, the results check well with those done by other methoas, because the amount of uranium and its daughter products is so small that any disequilibrium between the two would not significantly change the overall radioactivity, and the half-life of thorium daughter products is so short that in most deposits thorium and its daughter products are in equilibrium.

The samples represent a wide variety of vein materials. A few represent thin seams in a quartzite country rock but most are entirely of vein material. The material ranges from almost barren quartz vein to thorium- and iron oxide-rich parts of veins. Variations in grade may take place both across and along a vein. The hanging wall or footwall part of a vein may contain severalfold more $\mathrm{ThO}_{2}$ than the rest of the vein. A striking example of this relationship occurs in the south vein on the Lone Star No. 2 property (loc. 145), where a 1-foot-thick hanging wall, a dark-brown limonitic part of the vein, overlies a much thicker (9-30 feet thick), light-gray, quartz-rich part. In one prospect, two samples were cut across this vein; the hanging wall part contained 0.32 percent $\mathrm{ThO}_{2}$ and the footwall part 0.004 percent $\mathrm{ThO}_{2}$. Variations in grade are equally common along the veins. A somewhat extreme example occurs in a small adit near the south end of the Shear Zone vein where two channel samples cut across the entire vein some 20 feet apart contained 0.0081 and 2.49 percent $\mathrm{ThO}_{2}$.

Although the thoria content of individual parts of different veins may vary widely, the grade of large sections of a particular vein may be fairly constant. Seven samples along 300 feet of vein exposed in the main workings of the Lucky Horseshoe vein (loc. 1, fig. 18) range from 0.52 to 1.00 percent $\mathrm{ThO}_{2}$ (table 6). Five samples along 520 feet of the principal vein on the Deer Fraction 1 A (loc. 21, fig. 21) have values ranging from 0.18 to 0.59 percent $\mathrm{ThO}_{2}$ (table 8). Seven samples along 595 feet of the northwest-trending vein on the Black Rock (Montana) property (loc. 75, fig. 29) have a thoria content between 0.63 and 3.10 percent (table 15). Five samples along 420 feet of the northwest-trending vein on the Black Rock (Idaho) property (loc. 165, fig. 40) range from 0.16 to 0.62 percent $\mathrm{ThO}_{2}$ (table 23). Overall thoria 
TABLE 4.-Analyses of samples from the Lemhi Pass thorium district, Idaho and Montana

[C. chip sample: $\mathrm{CH}$, channel sample; G, grab sample; leaders(......) not determined; NA. not applicable]

\begin{tabular}{|c|c|c|c|c|c|c|c|c|c|c|c|c|c|}
\hline \multirow{2}{*}{$\begin{array}{l}\text { Locality } \\
\text { No. } \\
\text { (pl. 1) }\end{array}$} & \multirow{2}{*}{$\begin{array}{l}\text { Name of claim, where } \\
\text { known, and vein, if } \\
\text { more than one }\end{array}$} & \multirow{2}{*}{$\begin{array}{l}\text { Sample } \\
\text { No. } \\
\text { (MHS-) }\end{array}$} & \multirow{2}{*}{$\begin{array}{l}\text { Vein thicknes } \\
\text { (ft.) } \\
\text { and type }\end{array}$} & \multirow{2}{*}{ Description of locality } & \multicolumn{9}{|c|}{ Percent composition } \\
\hline & & & & & \multicolumn{3}{|c|}{${ }^{1} \mathrm{ThO}_{2}{ }^{12} \mathrm{RaeU}_{3} \mathrm{O}_{8}{ }^{1} \mathrm{~K}_{2} \mathrm{O}{ }^{34}$} & ${ }^{4} \mathrm{SRE}_{2} \mathrm{O}_{3}{ }^{4} \mathrm{Cu}$ & ${ }^{4} \mathrm{~Pb}$ & ${ }^{4} \mathrm{Zn}$ & ${ }^{4} \mathrm{Ba}$ & ${ }^{4} \mathrm{Sr}$ & ${ }^{4} \mathrm{Nb}$ \\
\hline $106 \mathrm{O}$ & Orpha & $33-70$ & $4.4 \mathrm{C}$ & Center of west trench. & 0.055 & $\ldots$ & 5.54 & & & & & & \\
\hline $109 \mathrm{LL}$ & Lucky Strike No. 2 .. & $22-70$ & $1.5 \mathrm{CH}$ & Center of east trench. & .024 & $\cdots$ & 1.89 & ……............ & ........... & $\ldots \ldots, \ldots$ & …..... & ,........... & …........ \\
\hline $112 \mathrm{Lu}$ & Lucky Strike No. 3 ... & $25-71$ & $.67 \mathrm{C}$ & Southwest trench in center of ridge & .088 & 0.0005 & 4.13 & $\ldots \ldots \ldots \ldots \ldots \ldots$ & ........... & ........... & …..... & ............ & ........ \\
\hline $113 \mathrm{Cl}$ & Chief Tendm Vos. 13 and 14. & $30)-70$ & $1.0 \mathrm{CH}$ & Northwest trench & .60 & & & ............. & (n) & ....... & ....... & ........ & ........ \\
\hline $114 \mathrm{w}$ & Welco No. 10 & $2-70$ & NA G & Trench adjacent to road & .77 & & & 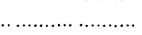 & ... & …....... & .......... & ...... & ........... \\
\hline $115 \mathrm{Cl}$ & Chief Tendoy No. 6 & $28-70$ & $8.0 \mathrm{C}$ & South wall of trench ........ & .63 & $\cdots \cdots$ & & ................ & ...... & ............ & ......... & ........... & .......... \\
\hline $121 \mathrm{Cl}$ & Chief Tendoy No. 2 & $34-70$ & $.5 \mathrm{CH}$ & Side of southeast trench. & .076 & $\ldots$ & 10.0 & …................... & ......... & ............. & .......... & ..... . & …..... \\
\hline 122 & 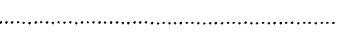 & $10-70$ & $1.5 \mathrm{C}$ & Back of secondmost eastward trench ................. & .93 & & & ….................... & ............. & .......... & .......... & ........ & ........... \\
\hline 122 & $\ldots .$. & 31.70 & $.9 \mathrm{CH}$ & $\begin{array}{l}\text { West branch of vein at west end } \\
\text { of northwest trench }\end{array}$ & .045 & .0004 & 10.01 & - & & & & & \\
\hline 126 & & $32-70$ & $3.0 \mathrm{C}$ & Between the two trenches & .19 & $\ldots$ & 3.25 & $\ldots \ldots .$. & & & & & $\cdots$ \\
\hline $132 \mathrm{Sa}$ & Sauser No. I & $35-70$ & $.4 \mathrm{CH}$ & Near center of trench & .28 & & & . & …...... & …..... & ......... & ......... & $\ldots \ldots \ldots$ \\
\hline $133 \mathrm{w}$ & Welco No. 7 & $6-70$ & $1.4 \mathrm{CH}$ & 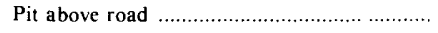 & .034 & .0003 & 2.02 & …................. & ........ & 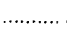 & ........ & ....... & ........ \\
\hline $135 \mathrm{~S}$ & South vein & $47-70$ & $.6 \mathrm{CH}$ & Back of trench. & .098 & $\ldots$ & 1.32 & ................... & ......... & & $\cdots .$. & & \\
\hline $137 \mathrm{R}$ & Red Hill No. 1 & $56-72$ & $.9 \mathrm{CH}$ & Back of trench & .19 & $\ldots$ & 6.42 & $0.67 \quad 0.0070$ & $0.015<$ & $<0.030$ & 0.70 & 0.070 & 0.015 \\
\hline $138 \ldots$ & 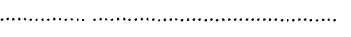 & $81-72$ & $.67 \mathrm{C}$ & East end of trench & .19 & $\cdots$ & $\ldots$ & $.76<.0002<$ & $<.0010$ & $<.030$ & 1.50 & .050 & .015 \\
\hline $143 \ldots$ & & $77-72$ & $.2 \mathrm{C}$ & Center long trench & .52 & & & . & $\ldots \ldots \ldots . .$. & & & & \\
\hline 149 Id & Idaho No. 3 & $28-72$ & $.67 \mathrm{C}$ & Center of vein ......... & .032 & .0012 & 7.73 & .051 .0003 & .0030 & $<.030$ & .070 & .015 & .030 \\
\hline 150 & & $83-72$ & $1.0 \mathrm{C}$ & High on south side of trench. & .029 & .0015 & 3.68 & .................. & ............ & ........... & 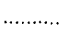 & & \\
\hline 15110 & lola . & $73-72$ & $1.2 \mathrm{C}$ & Side of trench & .36 & .0014 & 8.90 & $\ldots \ldots \ldots \ldots$ & 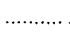 & $\cdots$ & ...... & ........ & $\cdots \cdots$ \\
\hline 15210 & Iola ............... & $72-72$ & $.67 \mathrm{C}$ & Pit just below road ..... & .39 & $\ldots$ & 2.51 & $.61 \quad .007$ & .015 & .20 & 1.50 & .70 & .15 \\
\hline \multirow[t]{2}{*}{157} & $\begin{array}{l}\text { Silver Queen No. (?) } \\
\text { Northeast vein ...... }\end{array}$ & & $.5 \mathrm{C}$ & & & & & & & & & & \\
\hline & 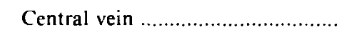 & $54-72$ & $.37 \mathrm{C}$ & $\begin{array}{l}\text { Northwest side of pit } \\
\text { Northwest side of pit }\end{array}$ & .19 & $\begin{array}{l}.0078 \\
.0034\end{array}$ & $\begin{array}{l}3.93 \\
7.16\end{array}$ & …....... & …….... & & & & \\
\hline 160 & (1) & $46-72$ & $.5 \mathrm{C}$ & 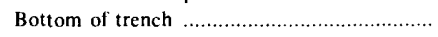 & .23 & $\ldots$ & .55 & ......................... & .............. & ......... & ....... & ......... & …............. \\
\hline $161 P$ & Pine Nos. I and 2 ........... & $9-72$ & NA G & Center of lower trench. & .19 & .041 & 11.6 & ….................. & …....... & ........ & ....... & ......... & ........... \\
\hline $162 \mathrm{~L}$ & Lucky Boy. & 6.72 & $1.0 \mathrm{C}$ & South side near lower end of trench ................. & .10 & .054 & 11.9 & …….............. & ........... & ........ & ....... & ........ & ........... \\
\hline $163 \mathrm{~B}$ & 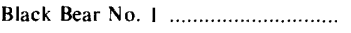 & $7-72$ & $N A G$ & South side of trench & .11 & $\ldots$ & 4.93 & ……............. & ........... & ...... & ....... & ......... & ........... \\
\hline $166 \mathrm{~S}$ & Scott & $93-72$ & NA G & Second trench from west & .079 & .014 & 5.07 & …….............. & .......... & .... & ...... & ......... & ........... \\
\hline $167 \ldots$ & ……........................ & $74-72$ & $.2 \mathrm{CH}$ & 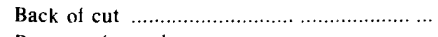 & .90 & $\cdots$ & 2.07 & ……............... & ....... & .... & & ....... & ........... \\
\hline $169 \mathrm{~K}$ & 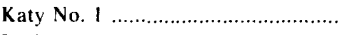 & $17-72$ & $.67 \mathrm{C}$ & Bottom of trench & .16 & $\cdots$ & 6.23 & $\cdots$ & ..... $>$ > & ... & & ..... & ........... \\
\hline $172 \mathrm{~B}$ & 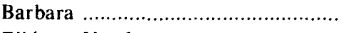 & $75-72$ & $1.8 \mathrm{CH}$ & 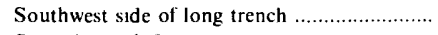 & .32 & .0035 & 4.14 & 1.92 .0015 & .015 & $.050>$ & $>2.00$ & .70 & .30 \\
\hline $178 \mathrm{E}$ & 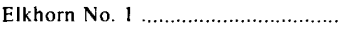 & $44-73$ & $2.0 \mathrm{C}$ & 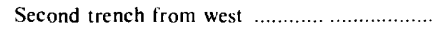 & .014 & .0003 & .60 & ..................... & $\ldots \ldots$ & …....... & …........ & ........... & 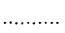 \\
\hline $180 \mathrm{~V}$ & 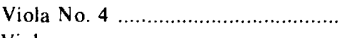 & $33-71$ & $1.7 \mathrm{C}$ & Center of trench complex & .77 & .0084 & 8.50 & $.81 \quad .015$ & $.010<$ & $<.030$ & .15 & .030 & .030 \\
\hline $181 \mathrm{~V}$ & Viola & $34-71$ & $1.1 \mathrm{C}$ & East trench & .034 & .0004 & 3.22 & ……............... & ......... & .......... & ........... & .......... & ............ \\
\hline $187 \mathrm{M}$ & Mornell & $3-73$ & NA G & Second pit trom top & .11 & .0006 & 8.06 & .............. & & & & & \\
\hline \multirow[t]{3}{*}{190} & Thor Nos. 1 and 2 & & & & & & & & & & & & \\
\hline & 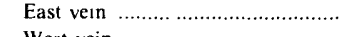 & $65-73$ & $.8 \mathrm{C}$ & East pit, adjacent to road ................................. & .16 & .0006 & 4.70 & & & & & & \\
\hline & West vein .................. & $66-73$ & $1.5 \mathrm{C}$ & 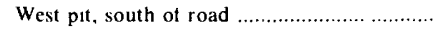 & .037 & .0007 & 6.26 & …................ & $\ldots$ & & ...... & & ..... \\
\hline \multirow[t]{2}{*}{$\ldots . \mathrm{D}$} & Daisy Nielsen Ranch & & & & & & & & & & & & \\
\hline & $\begin{array}{l}\text { West vein ...... } \\
\text { Middle vein .. }\end{array}$ & $78-73$ &. $\mathrm{CH}$ & $\begin{array}{l}\text { West side of north trench .... } \\
\text { Middle of south trench }\end{array}$ & $\begin{array}{r}1.14 \\
.75\end{array}$ & $\ldots$ & 7.35 & & & & & & \\
\hline .... M & 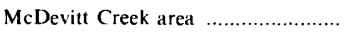 & $17-7 \mid$ & $1.3 \mathrm{C}$ & 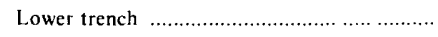 & .037 & .0003 & 1.24 & …................... & ......... & .......... & …..... & ........ & ............ \\
\hline
\end{tabular}

'Analyzed by gamma-ray spectrometer by C. M. Bunker and C. A. Bush. U.S. Geological Survey.

Equivalent $\mathrm{U}_{3} \mathrm{O}_{x}$ content as determined from radium daughter product.

'Total rare-earth oxides.

${ }^{4}$ Analyzed by semiquantitative six-step spectrographıc method by N. M. Conklin, U.S. Geological Survey.

content may also vary in different segments of veins. Thus, five samples on a 410-foot segment of the southeastern part of the northeast vein on the Reactor property (loc. 107, fig. 32) range from 0.14 to 1.32 percent $\mathrm{ThO}_{2}$, but two samples along a 320-foot segment of the northwestern part of this same vein range from 0.006 to 0.07 percent $\mathrm{ThO}_{2}$ (table 18). Four samples across the main pit, 200 feet across, on the $\mathrm{ThO}_{2}$ property (loc. 192, fig. 41) have 0.51-2.39 percent $\mathrm{ThO}_{2}$, but one sample taken 735 feet farther northwest has only 0.033 percent $\mathrm{ThO}_{2}$ (table 24). Most of the better explored veins have an average $\mathrm{ThO}_{2}$ content of 0.30 percent or greater. Some veins are much higher grade than others, and at least one vein on each of the following properties has an average grade in excess of 1.0 percent: Black Rock (Montana) (loc. 75), Elkhorn (loc. 108), Silver Queen 52B (loc. 146), $\mathrm{ThO}_{2}$ (loc. 192), and Shear Zone (loc. 73).
The total overall rare-earth oxide content of these veins is somewhat greater than the thoria content. As the atomic radius of thorium is similar to that of the various rare-earth elements, many primarily rare-earth minerals contain thorium, and vice versa. Thus, it would appear that samples rich in thorium would be rich in rare earths. This is not necessarily the case. Samples having similar concentrations of thoria and of the rare-earth oxides include six samples from the Last Chance (loc. 82) which contain 0.20, 0.18, 1.34, $0.28,0.61$, and 0.28 percent total rare-earth oxides and 0.36 , $0.26,1.45,0.30,0.61$, and 0.28 percent thoria, respectively. Similarly, a sample from the Viola No. 4 (loc. 180) contains 0.81 percent total rare-earth oxides and 0.77 percent thoria; a sample from M.S.D. No. 1 (loc. 86 ) has 0.26 percent total rare-earth oxides and 0.22 percent thoria; and a sample from the Thorite No. 3 (loc. 40 ) has 0.37 percent total rare-earth 
oxides and 0.38 percent thoria. On the other hand, other samples show little agreement between the amounts of rare earths and thorium. Three samples from the Apex (loc. 136) contain $1.67,1.11$, and 1.05 percent total rare-earth oxides and $0.32,0.24$, and 0.17 percent thoria, respecitvely. Similar wide variations occur on the Barbara property (loc. 172), where a vein has 1.92 percent total rare-earth oxides and 0.32 percent thoria; on the Black Rock (Montana) property (loc. 75), where the northwest vein has 0.11 percent total rare-earth oxides and 2.19 percent thoria; and on the Frying Pan property (loc. 85 ), where a vein contains 0.16 percent total rare-earth oxides and 1.35 percent thoria.

The rare earths consist of 16 elements having similar chemical properties. Fifteen of the elements-lanthanum (La), cerium (Ce), praeseodymium (Pr), neodymium ( $\mathrm{Nd}$ ), promethium $(\mathrm{Pm})$, samarium $(\mathrm{Sm})$, europium $(\mathrm{Eu})$, gadolinium (Gd), terbium ( $\mathrm{Tb}$ ), dysprosium (Dy), holmium (Ho), erbium (Er), thulium ( $\mathrm{Tm})$, ytterbium ( $\mathrm{Yb}$ ), and lutetium $(\mathrm{Lu})$-occur sequentially in the periodic table, elements 59 through 71 . This group is called the lanthanides. One of these, promethium, is almost unknown in nature. Yttrium, not one of the lanthanides, but chemically similar to them, is also classed as a rare earth. All rare earths have a $3^{+}$valence and similar atomic radii; hence, they can easily substitute for one another, and they are always found together.

In the normal distribution of the lanthanides in the earth's crust, and in most minerals, the ones having the even atomic numbers are more abundant than the adjacent odd-numbered ones, and the even- or odd-numbered lanthanides having a lower atomic number are more abundant than those having a higher atomic number. Generally, therefore, cerium is the most abundant lanthanide and lutetium the least. Although this distribution pattern of the lanthanides occurs in many minerals, it may be markedly different in a few, owing to partial separating out (fractionation) of the rare earths. In rocks in which the rare earths are not fractionated, cerium is the most common lanthanide having an even atomic number and lanthanum is the most common lanthanide having an odd atomic number. In the Lemhi Pass thorium district the rare-earth content of many veins has been fractionated, and the proportions of the rare-earth elements commonly vary in different veins. Complete rare-earth analyses were made of 31 samples from 21 veins and are reported by Staatz, Shaw, and Wahlberg (1972). These data show that cerium, expected to be the principal even-numbered lanthanide, was most abundant in only six samples. In 17 samples neodymium is the most abundant lanthanide; in three, gadolinium; in two, dysprosium; and in three samples two lanthanides are equally abundant. The larger amount of neodymium than cerium in most of these samples may not be due to its enrichment but rather to depletion of the cerium. In some environments cerium can be oxidized from $\mathrm{Ce}^{+3}$ to $\mathrm{Ce}^{+4}$ (Adams, 1969, p. C42) and may then be largely excluded from minerals containing the other rare earths. The mineral content of the samples, except for those rich in gadolinium, could not be directly correlated to lanthanide distribution. The three gadolinium-rich samples contained abundant brockite.

Generally, lanthanum is the most abundant lanthanide of odd atomic number in the thorium veins, but europium was the most common odd-numbered lanthanide in about one-third of the samples. Furthermore, in another 40 percent of the samples europium is enriched as compared with its neighboring odd-numbered elements (Staatz and others, 1972, p. 76-77). This enrichment of europium occurs in more than 70 percent of the samples and, hence, is an extremely common feature of the thorium veins.

The rare-earth content of these veins was more commercially valuable in 1975 , even though not producible economically, than the thorium content. The veins may be of particular value in the future for uses requiring neodymium or europium.

The uranium content of these deposits is small. When a sample has a $T h: U$ ratio greater than about 40 , the radiation due to thorium commonly interferes with the uranium measurement. This is especially true if the sample also has a high potassium content. At only one place did the amount of uranium exceed that of thorium. Veinlets at this locality (No. 31 ) occur in a different environment, replacing the basal conglomerate of the Challis Volcanics rather than, as normally, the Precambrian quartzite. These veinlets contain 0.014 percent $\mathrm{U}_{3} \mathrm{O}_{8}$ but only 0.0012 percent $\mathrm{ThO}_{2}$. At all other localities the thorium greatly exceeds the uranium content. The $\mathrm{U}_{3} \mathrm{O}_{8}$ content of 19 samples, as shown in table 4 , ranges from 0.0003 to 0.054 percent. The ratio of $\mathrm{ThO}_{2}$ to $\mathrm{U}_{3} \mathrm{O}_{8}$ in these samples ranges from 1.9 to 385 , but most fall in the range of 20 to 180 . Thus, uranium is not only of little economic importance, but the radiation due to uranium in most thorium veins is minor.

Copper, lead, zinc, molybdenum, gold, and silver have been detected in some of the thorium veins, but in most they occur in only minor amounts. Analyses of some of the veins in the Lemhi Pass quadrangle are given by Staatz (1972, table 5). Other analyses are given in tables $4,10,15,19$, and 21. Copper is by far the most widespread of these metals, and scant amounts of malachite are seen in many veins. Thirty-one copper analyses were made on 17 veins, all of which, in at least one place, have visible copper minerals. The copper content of these samples ranged from less than 0.0002-2.80 percent, but samples from only two properties, the Wonder (loc. 45) and the Black Rock (Montana) (loc. 75 ), exceeded 0.06 percent copper. Ten samples from the Wonder vein (table 10 ) yielded $0.15-2.80$ percent copper, and one sample from the Black Rock had 0.15 percent. The Wonder vein was first prospected for its copper content, and small amounts of copper-bearing on were shipped to the Copper Queen mill (Sharp and Cavender, 1962, p. 44).

Lead is considerably less common than copper. Lead 
minerals were not noted in the field, and only scant amounts of galena are present in heavy separates from two veins, pyromorphite from three, and wulfenite from one. Twenty-three analyses were made for lead on samples from 17 veins (tables 4, 10, 19, 21, and 23; Staatz, 1972, table 5). The lead content of these analyses ranged from less than 0.001-0.23 percent. High values came from a sample taken on the Silvertip property (loc. 104), which contained pyromorphite.

Zinc, when present, is found in minor amounts. Zinc minerals have only been identified from the Wonder vein. In 31 analyses from 17 properties the zinc content ranged from 0.0025 to 3.46 percent, but at only two properties, the Wonder and the Black Rock (Montana), is it in excess of 0.20 percent. In 10 samples from the Wonder, the zinc content ranged from 0.08 to 3.70 percent (table 10), and if this property is mined for thorium, zinc could be an important byproduct. One sample from the northwest-trending vein on the Black Rock property had 1.10 percent zinc (Staatz, 1972, table 5), and this property could possibly also be of economic importance.

Molybdenum is uncommon in the veins of this district. The only molybdenum minerals noted were a few rare pieces of molybdenite in heavy-mineral separates from veins on the Barbara property (loc. 172) and the Daisy Nielsen Ranch and a little yellow wulfenite from the Black Bear No. 2 property (loc. 37). Molybdenum minerals are most abundant in the vein on the Black Bear property, and a sample of the vein material in which the wulfenite was found contained 0.024 percent molybdenum (Staatz, 1972, table 5).

Little gold is present in the thorium veins. Only 7 of 39 samples contained more than 0.0015 ounces per short ton. The sample which had the most gold came from the Wonder vein (loc. 45); it yielded 0.020 ounce per short ton (table 10).

Silver is not common in the thorium veins, although moderate amounts have been found in a few veins. Two samples from the Wonder had 0.99 and 0.52 ounce per short ton, respectively (table 10). Significant amounts of silver also occur in samples from the Black Rock (Montana) (loc. 75; MHS-63-68), east vein of the Buffalo (loc. 18; MHS-142-68), and Last Chance (loc. 2; MHS-147-68) properties. Those samples contained $0.23 ; 0.38$, and 0.20 ounce per short ton of silver, respectively (Staatz, 1972, table 5). None of the other 31 samples yielded as much as 0.10 ounce per short ton of silver.

Microcline, as noted in the previous section, is one of the principal gangue minerals of the thorium veins. As other potassium-bearing minerals occur in such small amounts, more than 95 percent of the potassium in the veins is due to microcline. Thus, the potassium content of the veins can be used to estimate their microcline content. The potassium content of 82 samples from thorium veins was measured; the results of some of the samples are given in table 4 . The potassium content of the samples ranged from 0.46 to 12.4 percent. This correlates roughly with 3.3 to 88 percent microcline. Seven samples from the Black Bear No. 2 (loc. 37), Chief Tendoy No. 2 (loc. 121), locality 122, Pine Nos. 1 and 2 (loc. 161), Lucky Boy (loc. 162), and the $\mathrm{ThO}_{2}$ (loc. 192) contained 10 or more percent potassium ( 71 or more percent microcline).

The barium content of 15 samples from the Lemhi Pass district varied from 0.007 to less than 2 percent; most contained 0.03-1.5 percent barium. The strontium content of 15 samples ranged from 0.002 to 0.70 percent. No strontium minerals have been identified in the veins. Strontium is highest in those veins that contain the most barium, and lowest in those veins that contain the least barium. As both barium and strontium have two valences and their atomic radii are similar in size, the strontium most likely substitutes for barium in barite. The niobium content of 15 samples ranged from 0.002 to 0.30 percent. In samples that contain as much as 0.1 percent niobium, this element could become an important byproduct.

\section{RESOURCES}

The Lemhi Pass district has important resources of both thorium and rare earths. Of the total resources, only reserves are reported here; no attempt was made to estimate the hypothetical undiscovered resources. A total of 219 thorium veins were identified in the district. These range in size from thin veinlets that coat the surface of shears to the Last Chance (loc. 82) that ranges in thickness from 5 to 40 feet. In this study of reserves only veins that were at least 0.2 foot thick were considered. A total of 110 veins were at least that thick and were used in reserve calculations. Data used in calculating the reserves of veins came mainly from surface exposures. Only two veins, the Last Chance (loc. 82) and the Wonder (loc. 45), have their downward extension in part blocked out by both drill holes and underground workings. Part of the reserve figures from these two properties could be considered as measured. Reserve figures from all other properties are considered as either indicated or inferred. As the amount of measured reserves is small, they are included in this study with the indicated reserves. Indicated reserves in the veins in this district are those found in a block consisting of the traceable length of the vein times the average thickness times the depth, which is assumed to equal the length. Inferred reserves in the veins are those found in a block that surrounds the indicated reserves. Length of this block is half the indicated length or a quarter of the indicated length in each direction. This is shortened where geologic evidence indicated the vein had terminated, or lengthened where anomalous radioactivity was detected through the overburden. Thickness was the same as that used in calculating the indicated reserves. Depth of this block is $1 \frac{1}{2}$ times the trace of the vein or one half the indicated length below the block of indicated reserves. The inferred length of the vein, although hypothetical, is probably a conservative estimate. For the most part outcrops in this district are widely 
scattered, and veins are outlined along the ridges in trenches where the overburden is thin. The inferred lengths of some veins have been greatly extended by later work. The Last Chance vein is described by Sharp and Cavender (1962, p. 29) in 1952 as being exposed for about 1,200 feet. Since then, additional trenches have increased its known length to 4,350 feet. Many veins have been found in only one trench and other trenches either were not put in or failed to cut through the overburden. The thickness used in most veins, as previously stated, was the average thickness. In a few veins, however, different parts of the vein have radically different thicknesses. Here the average thickness was calculated for each part of the vein, and the reserves for each part of the vein were calculated separately. An example is the Cago No. 12 vein (loc. 49 ), where much of the eastern part of the vein averages 16.0 feet thick, but the western part and the east end are 4.3 and 5.5 feet thick, respectively. The depth of the veins, although definite data are lacking, appears to be of the same order of magnitude as the length. There are no apparent geologic restrictions on depth, as the Precambrian quartzite and siltite host rock are exposed over wide areas, and faults associated with the veins can be traced for many miles. Furthermore, veins have been found at all elevations where the Precambrian host rock is exposed from 9,430 feet on the Continental Divide to 5,240 feet on Pattee Creek, a vertical distance of 4,160 feet. Difference in surface elevation of individual veins is as much as 560 feet.

The strike length and depth used in calculating indicated reserves for those veins that are exposed in only one place is 50 feet. A tonnage factor of 12 cubic feet per short ton is used in converting vein volume to vein weight.

\section{THORIUM}

The amount of $\mathrm{ThO}_{2}$ in each vein is a product of the average grade and the tonnage. The average grade was obtained by weighing the analyses according to the length of each chip or channel sample. Thus, a sample 6 feet long carried twice as much weight in the overall average as a sample that was only 3 feet long. The few grab samples taken are assumed in these calculations to have come from where the vein is of average thickness. The grade of some veins is represented by only one sample; other veins are an average of as many as 17 samples.

Indicated $\mathrm{ThO}_{2}$ reserves of the Lemhi Pass thorium district are 176,500 short tons. Inferred $\mathrm{ThO}_{2}$ reserves of this district are 128,900 short tons. Total indicated and inferred $\mathrm{ThO}_{2}$ reserves are 305,400 short tons. The veins that contain these reserves vary in grade, but 99 percent of these reserves are in veins that contain at least 0.1 percent $\mathrm{ThO}_{2}$. As in most mining districts, the greater part of the reserves occur in a few veins. In the Lemhi Pass thorium district 96 percent of the total reserves are in the 10 largest veins. These veins are the Last Chance (loc. 82), Shear Zone (loc. 73), $\mathrm{ThO}_{2}$ (loc. 192), Black Rock (loc. 75), Contact (loc. 52), Cago No. 12 (loc. 49), G\&G Nos. 6 and 8 (loc. 89), G\&G Nos. 1, 2, and 5 (loc. 90), Lucky Horseshoe (loc. 1), and Beaverhead (loc. 64). These 10 veins have an overall average grade of 0.43 percent $\mathrm{ThO}_{2}$.

\section{RARE EARTHS}

The amount of rare earths in any vein, like that of thorium, is a product of the average grade and the tonnage. Data on grade of the rare earths in these veins are much more meager than those on thorium. Accurate rare-earth analyses are both difficult to make and costly to obtain. For these two reasons only 41 reasonably accurate analyses are available of 25 veins. For many of these 25 veins only one rare-earth analysis was made, although on the large Last Chance vein nine samples were analyzed for rare earths. Most of these analyses (39) were done in two stages. First, a chemical concentrate was made that contained all the rare earths and thorium, and then the individual rare earths in this separate were determined by X-ray fluorescence. Thirty-one of the 39 samples were analyzed in the laboratories of the U.S. Geological Survey in Denver, Colo.; the other eight samples were done in the laboratories of the U.S. Bureau of Mines in Salt Lake City, Utah. The detailed results of these analyses have been previously published by Staatz and others (1972, p. 76-77) and by Austin (1968), respectively. The other two samples were analyzed by a quantitative spectrographic method. in the U.S. Geological Survey laboratories in Denver.

The 25 veins for which some analytical data on rare earths is available are: (1) Lucky Horseshoe (loc. 1), (2) vein at locality 4, (3) vein at locality 5, (4) principal vein on Buffalo property (loc. 18), (5) Black Bull Fraction No. 4, (6) vein at locality 35, (7) Thorite No. 3 (loc. 40), (8) Contact (loc. 52), (9) Shear Zone (loc. 73), (10) northwest-trending vein on Black Rock (Montana) property (loc. 75), (11) Last Chance (loc. 82), (12) central vein on Frying Pan property (loc. 85), (13) southeast vein on Frying Pan property (loc. 85), (14) M-S-D No. 7 (loc. 86), (15) G\&G Nos. 6 and 8 (loc. 89), (16) G\&G Nos. 1, 2, and 5 (loc. 90), (17) Thorite No. 1 (loc. 93), (18) Saddlehorn No. 3 (loc. 94), (19) H.R.S. No. 1 (loc. 95), (20) north vein on Dan Patch property (loc. 98), (21) south vein on Dan Patch property (loc. 98), (22) Atomic Blast (loc. 105), (23) Apex (loc. 136), (24) south vein on Silver Queen $38 \mathrm{~A}$ (loc. 148), and (25) northwest-trending vein on Black Rock (Idaho) property (loc. 165). Indicated reserves of rare-earth oxides in these 25 veins total 186,000 short tons, and inferred reserves of rare-earth oxides total 122,000 short tons.

A ratio of the rare-earth oxide reserves to the thoria reserves of these 25 veins is 1.33 or four parts rare-earth oxides to three parts thoria. An estimate can be made of the total rare-earth oxide reserves of the entire district by assuming that the relation between these two compounds in the 25 veins is the same as that for the district. Using this assumption, the total indicated and inferred reserves of 
rare-earth oxides for the Lemhi Pass district is 406,000 short tons.

\section{OTHER VEINS}

In addition to thorium veins, 15 copper veins, 15 barren quartz veins, and 2 iron veins occur in the Lemhi Pass district. The most economically important of these are the copper veins. In this report the term copper veins is reserved for any vein that contains copper minerals but does not contain thorium. This division is used because some thorium veins contain a little copper, and the thorium veins can be shown to be younger than those copper veins that do not contain thorium. With two exceptions, the copper veins occur either in the northeast part of the area or on the east side of the Lemhi River just north of the mouth of Little Dry Gulch. Veins at three localities, Copper Queen (loc. 43), Bluebird (loc. 30), and Last Chance (loc. 184), have produced small amounts of copper ore. The value of production at the Copper Queen from its discovery in 1893 until 1910 was approximately $\$ 100,000$ (Umpleby, 1913, p. 120). Since that time the mine has been operated sporadically, but production appears to have been small (Schipper, 1955, p. 7-10). A minor part of the total receipts at this property was due to gold. The Bluebird has a recorded production of 8 short tons of ore containing 1,432 pounds of copper, 3.6 counces of gold, and 68 ounces of silver (Weed, 1926, p. 788). The Last Chance (loc. 184) reportedly produced about 40 short tons of copper ore (Pete Mahaffey, oral commun., 1973). Other veins are generally both smaller and much leaner. At two localities (Nos. 8 and 36) the copper minerals are in seams or they coat fractures in shear zones. At other localities the copper minerals occur in quartz veins that range in thickness from 0.5 inch to 9 feet. The Copper Queen vein ranges in thickness from a few inches to 9 feet and has an average thickness of about 3.5 feet (Schipper, 1955, p. 27). The Last Chance vein (loc. 184) was also about 3.5 feet thick. The exposed length of the copper veins ranges from 5 to 1,300 feet. The four longest veins are the main vein on the Copper Queen (loc. 43), the Rufus (loc. 25), the southern or Lupine vein on the Copper Queen property, and the large vein on the Bluebird property (loc. 30), which have been traced 1,300,850,500, and 450 feet, respectively.

Strikes of the copper veins range from almost due north $\left(\mathrm{N} .3^{\circ} \mathrm{W}^{\circ}\right)$, to almost east-west $\left(\mathrm{N} .85^{\circ} \mathrm{W}\right.$.). Unlike the thorium veins, more than half of the copper veins ( 8 of the 13 measured) have a northeast strike. Dips are moderate to steep and may be variable. The north vein on the Copper Queen follows a curved fault, and above the 150 -foot level this vein dips $40^{\circ}-70^{\circ} \mathrm{NW}$., but below this level the dip reverses so that on the 250 -foot level the vein dips steeply southeast (Schipper, 1955, p. 27). The copper veins were deposited along shears, fractures, and small faults. Shears can be seen along one or both sides of the vein on the Idaho Pride property (loc. 28), the two veins on the Copper Queen property (loc. 43), and the vein on the Last Chance (loc. 184). The fractures containing these veins are all related to major faulting, most of them to faulting of Tertiary age. Twelve of the 13 copper veins or shear zones in the northeast part of the area lie within 1 mile, and 9 of the veins are within 0.25 mile of one of three big Teritary faults in this part of the area. The other vein (loc. 36) lies directly beneath a thrust fault of uncertain age. Ten of these veins occur in an area where three large Tertiary faults either intersect or approach each other. The three copper veins which lie just to the east of the Lemhi River are within 300 feet of a northward-trending fault that separates Precambrian quartzite and siltite. The strike of the copper veins is at an acute angle to that of the neighboring faults (pl. 1), although the strike of the Last Chance (loc. 184) vein is nearly at right angles to that of the adjacent fault. The fractures that most of the thicker veins fill were probably formed by tension, and some of the larger veins, such as the Rufus (loc. 25), the two veins on the Copper Queen property (loc. 43), the vein at locality 182, and the Last Chance (loc. 184), resemble gash veins.

The copper veins consist primarily of a white quartz gangue and primary and secondary copper minerals and secondary iron minerals. On the surface, malachite, chrysocolla, and azurite may be the only copper minerals seen. At depth, bornite and chalcopyrite are commonly present. Bornite is the principal ore mineral at the Copper Queen and has also been reported at the Idaho Pride (loc. 28) and No Pay (loc. 8) properties (Sharp and Cavender, 1962, p. 53 and 54). Chalcopyrite is present at the Copper Queen, Idaho Pride, and Last Chance properties. A little covellite and black copper oxides have been found on some of these properties. Specularite and limonite are commonly present in parts of these veins but are much less common than in the thorium veins. Other minerals include gold, calcite, pyrite, and molybdenite at the Copper Queen, and barite at the Bluebird (loc. 30). The Copper Queen mine is described by Schipper (1955) and Sharp and Cavender (1962, p. 51-52).

Barren quartz veins, like copper veins, are most common in the northeast part of the area (pl. 1), where 12 of the 15 veins are found. These veins tend to be small and range in length from 6 to 310 feet. The longest vein is adjacent to a thorium vein on the Wonder No. 18 property (loc. 70). Eight of the veins have been traced for less than 50 feet. Vein thickness varies from 0.2 to 25 feet. Individual veins may pinch and swell; for instance, the vein on the Blue Boar (loc. 32) ranges from 0.2 to 1 foot in thickness. Most of the quartz veins have an easterly trend, individual strikes ranging from N. $40^{\circ}$ W. through east-west to N. $55^{\circ}$ E. Overall, the strike of these veins is similar to that of the thorium veins, but where adjacent to a thorium vein the strike of the two differ. For example, at locality 16 the quartz vein strikes east-west and the thorium vein N. $40^{\circ} \mathrm{W}$. At the Wonder No. 18 property (loc. 70), the large quartz vein strikes N. $70^{\circ} \mathrm{E}$. toward an adjacent thorium vein that strikes $\mathrm{N} .70^{\circ} \mathrm{W}$. (fig. 27). The quartz veins dip steeply either north or south. 
The quartz veins, like the thorium and copper veins, were deposited along shears, fractures, and small faults. Movement along at least some of the veins continued after the veins were emplaced, as both the Blue Boar (loc. 32) and the Blue Ridge (loc. 48) are in part brecciated. Most of the barren quartz veins were intruded along fractures within a short distance of the large Tertiary faults in the northeastern part of the area. Their distribution is similar to that of the copper veins which, except for the lack of copper minerals, they closely resemble. The barren quartz veins consist principally of white to gray opaque quartz with minor amounts of limonite and hematite. In one vein (loc. 27) a small amount of chlorite was found and in two others (locs. 32 and 48) Sharp and Cavender (1962, p. 56) reported a little chalcedony, montmorillonite, rutile, and pyrite. A vein in the southern part of the area (loc. 193) is somewhat different from the other quartz veins in containing much more limonite and hematite than the other veins. This vein also contains some calcite, clay minerals, white platy barite, and a little spinel. Although these veins were examined both mineralogically and radiometrically, I did not find any recognizable minerals that contained any valuable metals.

Two iron veins occur in sec. 6, T. 17 N., R. 25 E., in the south-central part of the area on the north side of Reese Creek (pl. 1). The smaller vein (loc. 194) is exposed for 150 feet and has an average thickness of 8 feet; the larger vein (loc. 195) is exposed for 450 feet and is 10-40 feet thick. The length of the latter vein cannot appreciably be extended, because to the northwest it abruptly pinches out and to the southeast a large Tertiary fault cuts it off. The larger vein is on the Hematite claim which was located in May 1957 by Carroll Wells and associates (Anderson, 1961b, p. 103-104). The edges of this vein are not sharply defined, as irregular masses and veinlets extend outward into the country rock. The vein is massive in its central and northwestern parts, but in its southeasternmost exposure, it is brecciated. This vein is composed chiefly of specularite with some associated martite (Anderson, 1961b, p. 104). Little quartz is found in most of this vein. The vein at locality 194, on the other hand, contains more quartz and is a mixture of specularite and quartz. These two iron veins are too small to be of economic importance.

\section{ORIGIN}

Although all the veins in the Lemhi Pass thorium district intrude Precambrian siltite and quartzite, they are post-Challis Volcanics and postdiorite in age. The post-Challis age for these veins is suggested by two lines of evidence: (1) The shears and fraciures along which the veins are deposited are related for the most part to large faults of Tertiary age. The greatest concentration of veins is found in the northeast part of the area, where most of the veins are within 1 mile of three large converging Tertiary faults. (2) Three small thorium veins lie along major faults that offset the Challis Volcanics. Two small veins at localities 4 and 149 occur in the fault zone of the Lemhi Pass fault, and another vein is found at locality 150 on the Pattee Creek fault. The postdiorite age is indicated in the workings of the Copper Queen mine (loc. 43), where Schipper (1955, p. 21) reported four diorite dikes mineralized by copper veins. The copper veins are somewhat older than the thorium veins, as indicated by a thorium vein found along a small fault that offsets a copper vein a few feet about 350 feet from the portal of the lowest adit of the north vein of the Copper Queen mine (Schipper, 1955, p. 30, pl. 13). The veins are, thus, middle Tertiary or later in age. As previously noted, although the Tertiary faulting is later than most of the Challis Volcanics, it isn't much later. The two were probably generated during the same period of tectonism. The veins may also have been deposited during the latter part of this period. As the volcanics make up the greater part of the igneous rocks in this area, it is possible that the veins are a late-stage derivative of the magma from which the volcanics were derived. If this is so, then the Challis might be expected to contain abnormal amounts of thorium. To check this hypothesis several tuffs and flow rocks were analyzed for thorium and uranium (table 5). The average thorium content of three dark flow rocks is 10.8 parts per million (ppm) and for three rhyolitic tuffs is $14.0 \mathrm{ppm}$; the average uranium content of the flow rocks is $2.24 \mathrm{ppm}$ and of the tuffs 2.93 $\mathrm{ppm}$. The more silicic rhyolite tuffs have a slightly higher thorium and uranium content, as would be expected, than the flows, which appear in hand specimen to be andesitic or rhyodacitic in composition.

The thorium and uranium contents of volcanic rocks vary considerably, and depend in part on the alkalic and silicic contents of the rocks. For comparison, the thorium and uranium contents of volcanic rocks having a similar composition, from two other areas, are reported below. Four samples of volcanic rocks, ranging from andesite to rhyodacite in composition, from the Valles Mountains, $\mathbf{N}$. Mex., contained 5.2-15.3 ppm thorium and 1.6-3.7 ppm uranium (Larsen and Gottfried, 1960, p. 165). Four other samples of rhyolite from this area yielded $12-46 \mathrm{ppm}$ thorium and 4.0-18 ppm uranium. Three samples of andesite

TABLE 5.--Thorium and uranium content of rocks from the Challis Volcanics

[Analyses by gamma-ray spectrometer by C. M. Bunker and C. A. Bush]

\begin{tabular}{|c|c|c|c|c|c|}
\hline $\begin{array}{c}\text { Sample } \\
\text { No. }\end{array}$ & Unit & Description & $\underset{(\mathrm{ppm})}{\mathrm{Th}}$ & $\underset{(\mathrm{ppm})}{\mathrm{U}}$ & I h:U \\
\hline $\mathrm{MHS}-72-7.3$ & $\begin{array}{l}\text { Basalt-rhyodacite } \\
\text { sequence. }\end{array}$ & $\begin{array}{l}\text { Greenish-black aphanitic } \\
\text { flow rock. }\end{array}$ & 14.3 & 2.38 & 6.0 \\
\hline MHS-73-73 & ........................ & $\begin{array}{l}\text { Dark-brown aphanitic } \\
\text { flow rock. }\end{array}$ & 8.52 & 2.01 & 4.2 \\
\hline MHS-79-73 & $\ldots \ldots$. do $\ldots \ldots \ldots$ & 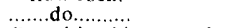 & 9.72 & 2.34 & 4.2 \\
\hline MHS-74-73 & $\begin{array}{l}\text { Tuff of Curtis } \\
\text { Ranch. }\end{array}$ & $\begin{array}{l}\text { Greenish-white crystal } \\
\text { tuff having abundant } \\
\text { quart? and sanidine } \\
\text { fragments. }\end{array}$ & 19.5 & 3.62 & 5.4 \\
\hline MHS-75-7.3 & $\begin{array}{l}\text { Quartzite-bearing } \\
\text { rhyolite tuff. }\end{array}$ & $\begin{array}{l}\text { Quartite fragments in } \\
\text { crystal tuff with } \\
\text { abundant clear quarty } \\
\text { fragments. }\end{array}$ & 12.8 & 2.98 & 4.3 \\
\hline MHS- $80-73$ & ......do......... & .......do.............. & 9.83 & 2.18 & 4.5 \\
\hline
\end{tabular}


and dacite from the Modoc area of California yielded 3.9-10.8 ppm thorium and three samples of rhyolitic rocks had 14.1-15.5 ppm thorium. The uranium content of five samples of andesite and dacite from the Modoc area was 1.4-4.4 ppm and that of eight samples of rhyolitic rocks was 4.4-5.6 ppm (Z. E. Peterman, written commun., 1963). The thorium and uranium contents of these three suites of volcanic rocks from three different regions have similar ranges except that the rhyolitic rocks from the Valles area contain almost twice as much thorium and uranium as do the rocks of the Lemhi Pass district. Thus, the overall thorium and uranium contents of the Lemhi Pass rocks are not anomalously high compared to other areas. Furthermore, although thorium is greatly in excess of uranium in the veins, the thorium-to-uranium ration of the Challis Volcanics is similar to that found in rocks in unmineralized areas. The thorium-to-uranium ratios of the six analyzed samples from the Challis range from 4.2 to 6.0 (table 5). Graphs of the thorium-uranium ratios compiled by Clark, Peterman, and Heier (1966, p. 536-537) for mafic, intermediate, and granitic rocks show some scatter but have average values of 4.0 , which is slightly but not significantly less than the ratios obtained from the Challis Volcanics.

Thorium veins are not unique to the Lemhi Pass district. They have been described in 13 separate areas in the United States (Staatz, 1974). The most important geologic relation in many of these districts is the association of the thorium veins with alkalic rocks and carbonatites. Although alkalic rocks and carbonatites are sparse in the United States, one or both are found in 8 of the 13 areas. Although no alkalic intrusives have been found in the Lemhi Pass area, a small carbonatite dike is exposed in a small pit on the Continental Divide adjacent to locality 77 . This rock forms a small gray dike only a few feet long, which consists principally of calcite with rosettes of iron oxide-stained apatite crystals and masses of green chlorite and black magnetite. In addition, this rock contains minor amounts of specularite, goethite, chalcopyrite, malachite, and monazite. The presence of the carbonatite in this district, as well as the association of thorium veins with alkalic rocks in other districts (Staatz, 1974), suggests that alkalic rocks are present at depth.

The thorium veins probably were precipitated from fluids derived from a magma that formed buried alkalic rocks. These fluids followed major through-going fractures, but the veins generally were deposited in subsidiary breaks. The large area over which the veins are spread, as well as tight shears that some of the fluids migrated along, indicates that the vein fluids were of low viscosity. The length of time needed to form these veins probably varied, but for many this period was long enough for vein material to be deposited, to be fractured by later movement, and then for new vein material to fill the fractures. That the temperature of vein formation was probably low is suggested both by the fine grain size of the veins and the distance that some of the fluids apparently traveled.

\section{DESCRIPTION OF SELECTED THORIUM VEINS}

\author{
By Mortimer H. StaAtz. U.S. Geological Survey, \\ and Brron J. Sharp and Donald L. Hetland, \\ U.S. Energy Research and Development Administration
}

We do not attempt to describe all the veins in the district, as little data are available on many. Some veins are known only from one spot in the bottom of one trench. Other veins have been uncovered in several trenches, but sloughing of the sides commonly has left poor exposures. Some of the veins that were exposed in the workings prior to 1953 are described by Trites and Tooker(1953, p. 193-195) and Sharp and Cavender (1962, p. 29-50). These include the following claims: Wonder, Buffalo No. 1 and No. 2, Wonder No. 18, Lucky Strike No. 1 and No. 2, Trapper No. 1 and No. 4, Brown Bear, Last Chance, Shady Tree, Radio (Black Rock), Bull Moose, Black Bull No. 2 and No. 3, Uranium Queen, and Three-and-One. We have described selected veins from the 23 localities from which we have the best data. In general, they include the larger veins in the district. The descriptions do not include all the largest veins, for instance, the Iola and the Shear zone, each of which is more than 2,000 feet long. We have included some veins previously described by Sharp and Cavender (1962) and Trites and Tooker (1953), such as the Last Chance and the Buffalo, where subsequent development work and mineralogic studies have substantially added to the knowledge of the veins at these localities.

The following properties are described in detail: Lucky Horseshoe (loc. 1), Buffalo (loc. 18), Black Bull No. 2 (loc. 20), Deer Fraction 1A (loc. 21), Black Bear No. 2 (loc 37), Wonder (loc. 45), Cago No. 12 (loc. 49), Contact (loc. 52), Beaverhead (Montana) (loc. 64), Wonder No. 18 (loc. 70), Little Dandy (loc. 72), Black Rock (Montana) (loc. 75), Last Chance (loc. 82), Dan Patch (loc. 98), Reactor (loc. 107), Elkhorn (loc. 108), Apex (loc. 136), Lone Star No. 2 (loc. 145), Silver Queen 52B (loc. 146), Silver Queen 38A (loc. 148), Nellie B (loc. 153), Black Rock (Idaho) (loc. 165), and $\mathrm{ThO}_{2}$ (loc. 192).

\section{LUCKY HORSESHOE}

The Lucky Horseshoe (loc. 1) vein crosses Flume Creek about 1 mile northeast of its junction with Agency Creek. It lies on the lower frontal slope of the mountain where Flume Creek emerges from a deep rocky canyon and enters a broad basin. The principal workings lie on the nose of a ridge on the west side of the creek in the NW1/4SE $1 / 4$ sec. 9, T. 19 N., R. 25 E., Boise meridian, Idaho. It is most easily reached by following a secondary road up Flume Creek which leaves the Lemhi Pass road about 0.25 mile east of Flume Creek.

A group of 12 claims makes up the Lucky Horseshoe group and the principal workings are on the Lucky Horseshoe No. 1. This claim was located on May 31, 1954, by Tony N. Nardello, Ernest A. Woodman, and Clyde Goodwin. In 1957 the property was leased to Fred Gunderjohn who subsequently developed the property by means of 


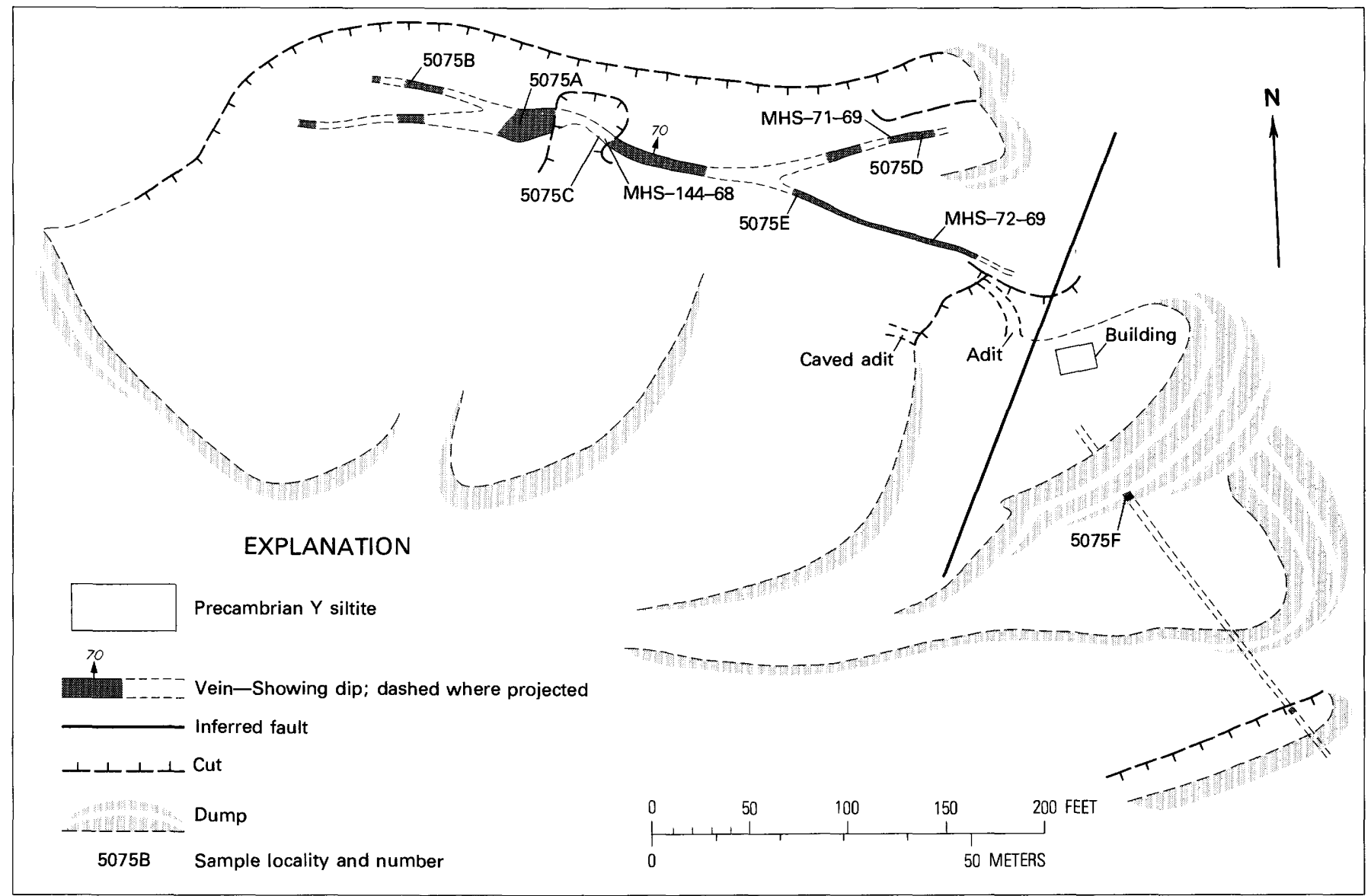

FIGURE 18.-Geologic map of the west end of the Lucky Horseshoe vein (loc. 1). Mapped by B. J. Sharp and D. L. Hetland, 1965; revised by M. H. Staatz, 1973.

extensive bulldozer trenches. Later, Harvey V. Bell became a part owner of this property and in 1972 the assessment work was done by Bell and Goodwin. The principal workings consist of several large cuts and two short adits (fig. 18). The largest cut, where the vein is best exposed, is 440 feet long. East of the cuts shown in figure 18, four trenches cut the vein on the steep west side of Flume Creek. East of Flume Creek, on the Lucky Horseshoe No. 10 claim, a trench in a broad bulldozed area exposes the extension of the main vein.

The Lucky Horseshow vein lies approximately parallel to and 700 to 1,000 feet north of the Lemhi Pass fault. The main workings expose highly sheared rocks that have a general east-west strike and dip $45^{\circ}$ south. The rocks east of Flume Creek are also sheared and the beds in several pits are highly contorted. One or more subsidiary faults of the main Lemhi Pass fault probably pass through the mine workings. The country rock is greenish-gray siltite of Precambrian Y age. The greenish color is due to epidote. Adjacent to the vein, however, the siltite is dark gray or black. This vein is one of the few in the area in which siltite is the host rock. The siltite near the vein strikes N. $70^{\circ} \mathrm{W}$. to N. $60^{\circ} \mathrm{E}$. and in general dips gently to the north.
The vein has several branches (fig. 18). The principal vein has an overall strike of $\mathrm{N} .70^{\circ} \mathrm{W}$. The smaller branches strike from N. $80^{\circ}$ W. to N. $80^{\circ}$ E. Dip is $50^{\circ}-75^{\circ}$ N. Exposed length is 1,400 feet. The vein thickness ranges from less than an inch to 20 feet. Unlike most veins in this district whose fluids were confined to a fracture or replaced granulated material along fractures, the vein material at the Lucky Horseshoe also erratically replaced parts of certain beds adjacent to the fractures. The thickness of the vein, therefore, can change radically within a few feet. The vein is thickest in the principal workings, but consists only of a few small seams in the easternmost workings. The vein is brecciated, black to gray, and commonly contains augen of light-colored unfractured feldspar and quartz surrounded by a granulated dark-gray matrix. Shearing of vein material gives it a marked foliation, and the vein commonly resembles a banded gneiss. In some places there are augen-shaped bodies of unreplaced siltite. The principal gangue mineral is microcline; quartz is also common. The black color is due chiefly to abundant black shiny plates of specularite and biotite. A little magnetite is also present. Allanite is the most common thorium-bearing mineral. This is the only vein in 
TARLE 6.-Analyses of samples from the Lucky Horseshoe vein, Idaho

[C, chip sample; Ch, channel sample; n,d., no data]

\begin{tabular}{|c|c|c|c|}
\hline Sample No. & $\begin{array}{l}\text { Sample } \\
\text { length and } \\
\text { type } \\
\text { (ft) }\end{array}$ & $\begin{array}{c}\mathrm{ThO}_{2} \\
\text { (percent) }\end{array}$ & $\begin{array}{c}\text { Total } \\
\text { rare-earth } \\
\text { oxides } \\
\text { (percent) }\end{array}$ \\
\hline 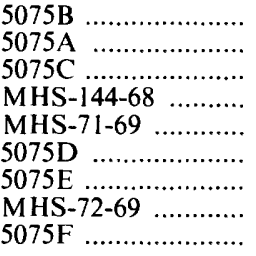 & $\begin{array}{l}1.5 \mathrm{C} \\
8.0 \mathrm{C} \\
6.0 \mathrm{C} \\
.8 \mathrm{C} \\
1.5 \mathrm{C} \\
6.0 \mathrm{C} \\
4.0 \mathrm{C} \\
2.8 \mathrm{Ch} \\
2.0 \mathrm{C}\end{array}$ & $\begin{array}{l}1.00 \\
1.52 \\
1.47 \\
3.89 \\
3.80 \\
1.62 \\
1.71 \\
3.047 \\
1.72\end{array}$ & $\begin{array}{l}{ }^{2} 10.95 \\
23.16 \\
\text { N.d. } \\
4.35 \\
\text { n.d. } \\
\text { n.d. } \\
\text { n.d. } \\
\text { n.d. } \\
24.29\end{array}$ \\
\hline
\end{tabular}

'Wet chemical analysis by Lucius Pttkin, Inc., Grand Junction, Colo. 'X-ray fluorescence spectrographic analysis by the U.S. Bureau of Mines, Salt Lake City. Utah.

'Gamma-ray spectrometric analysis by C. M. Bunker and C. A. Bush. U.S. Geological Survey, Denver, Colo.

4X-ray fluorescence spectrographic analysis by J.S. Wahlberg and V.S. Shaw, U.S. Geological Survey, Denver, Colo.

the district in which this mineral is abundant. Other thorium-bearing minerals are dark-red thorite and dark-brown monazite. Other minerals identified in this vein are muscovite, barite, plagioclase, calcite, apatite, rutile, chalcopyrite, and fluorite. The latter three minerals are very rare. Nine samples were taken from the various branches of this vein in the main workings (fig. 18). These samples ranged from 0.047 to 1.00 percent $\mathrm{ThO}_{2}$ (table 6). The total rare-earth oxide content obtained from four of these samples ranged from 0.35 to 10.95 percent. The unusually high rare-earth content of this vein could be expected from its high allanite content.

\section{BUFFALO}

A series of workings (loc. 18) collectively known as the Buffalo mine lies on a gently sloping ridge on the north side of and 300 feet above Agency Creek, about 0.75 mile north of the Copper Queen mine in the NW1/4 sec. 15, T. 19 N., R. 25 E. The property is reached by a secondary road up the Flume Creek basin that leaves the Lemhi Pass road about 0.25 mile east of where the latter road crosses Flume Creek.

This property was originally prospected for copper and gold, and 100 short tons of copper ore was reported to have been mined from a shaft that now lies under a mine dump near the location of sample MHS-74-69 (fig. 19) (Trites and Tooker, 1953, p. 195). In the early 1950's these claims were relocated for thorium by G. E. Shoup and Earl Pyeatt of Salmon, Idaho. In 1953 ownership was transferred to Irwin C. Porter and Frank Hussey of Salmon. In 1958 the claims were leased by Empire Explorations, Inc., of New Jersey, who made many bulldozer trenches and did some drilling. Lawrence Gini did the assessment work on this property in August 1973.

Early work consisted merely of a deep shaft and several adits. Later work consisted primarily of bulldozer trenches. The later trenching has obliterated the shaft and covered the adits in the northwestern and southern workings shown in figure 19. The adit shown on the eastern edge of the map follows a thorium vein for 90 feet. Bulldozing has made new trenches and changed old ones since the early 1950's. Figure 19 shows the workings as of September 1973. These workings lie on the Buffalo No. 2 and Buffalo No. 4 claims.

Country rock is a gray fine-grained micaceous quartzite that is shattered and brecciated. The property lies about 1,000 feet south of the Lemhi Pass fault and just east of a fault that brings the Challis Volcanics in contact with the Precambrian Y quartzite (pl. 1). Four, possibly five, veins were exposed in the workings in 1973. The principal vein lies in the eastern workings and has the adit driven along it (fig. 19). This vein has a north to northwest strike. At the mouth of the adit it strikes N. $5^{\circ} \mathrm{W}$. and dips $60^{\circ} \mathrm{SW}$. It can be traced in almost continuous outcrop for 280 feet. Two exposures in the southernmost working (fig. 19) may be a branch of this vein or may be a separate vein. If they belong to the principal vein, then they extend the known length to 550 feet. The principal vein ranges from 1.0 to 11.0 feet thick, being thickest near the portal of the adit.

The vein is medium brown to dark brown and is brecciated. Gangue minerals consist of abundant quartz, much of which is stained brown by limonite, and a little microcline. Specularite in flat shiny black plates is the principal iron oxide mineral. Limonite is common and in places occurs as tiny dark-brown cubes, a pseudomorphous replacement of pyrite. Some magnetite is also present. The chief thorium mineral is reddish-brown shiny thorite, although sparse crusts of clear-yellow monazite occur. In addition, minor brassy pyrite cubes and dark-brown to amber rutile were noted. Three samples were taken near the portal of the adit (fig. 19, table 7). One of these samples (MHS-141-68), taken at the widest spot, 11 feet, yielded 0.098 percent $\mathrm{ThO}_{2}$. A second sample (MHS-142-68), consisting of the most radioactive 1.5 feet of the first sample, yielded 0.48 percent $\mathrm{ThO}_{2}$. The total rare-earth oxide content of the entire 11 feet was 0.12 percent, but that of the most radioactive part was only 0.073 percent (Staatz, 1972, table 5). The third sample (5080C), taken about 10 feet away where the vein had thinned to 20 feet, yielded 1.05 percent

TABLE 7.-Analy'ses of samples from the Buffalo property, Idaho [C, chip sample; G, grab sample; n.d., no data]

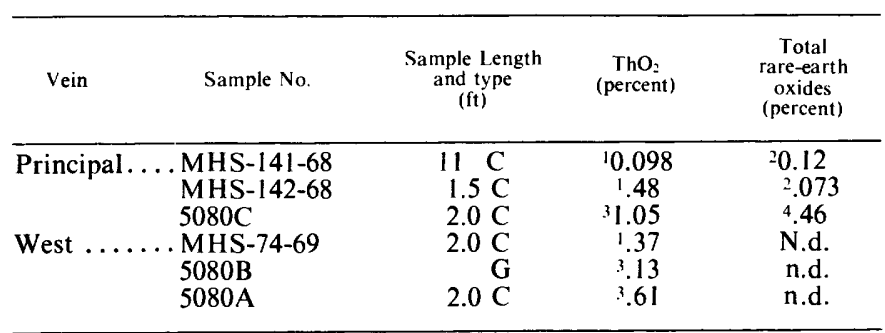

'Gamma-ray spectrometric analysis by C. M. Bunker and C. A. Bush, U.S. Geological Survey Denver, Colo.

${ }_{2 X}$-ray tluorescence spectrographic analysis by J.S. Wahlberg and V.S. Shaw. U.S. Geological Survey. Denver, Colo

Wet chemical analysis by Lucius Pitkin, Inc., Grand Junction. Colo.

tX-ray fluorescence spectrographic analysis by the U.S. Bureau of Mines, Salt Lake City. Utah. 


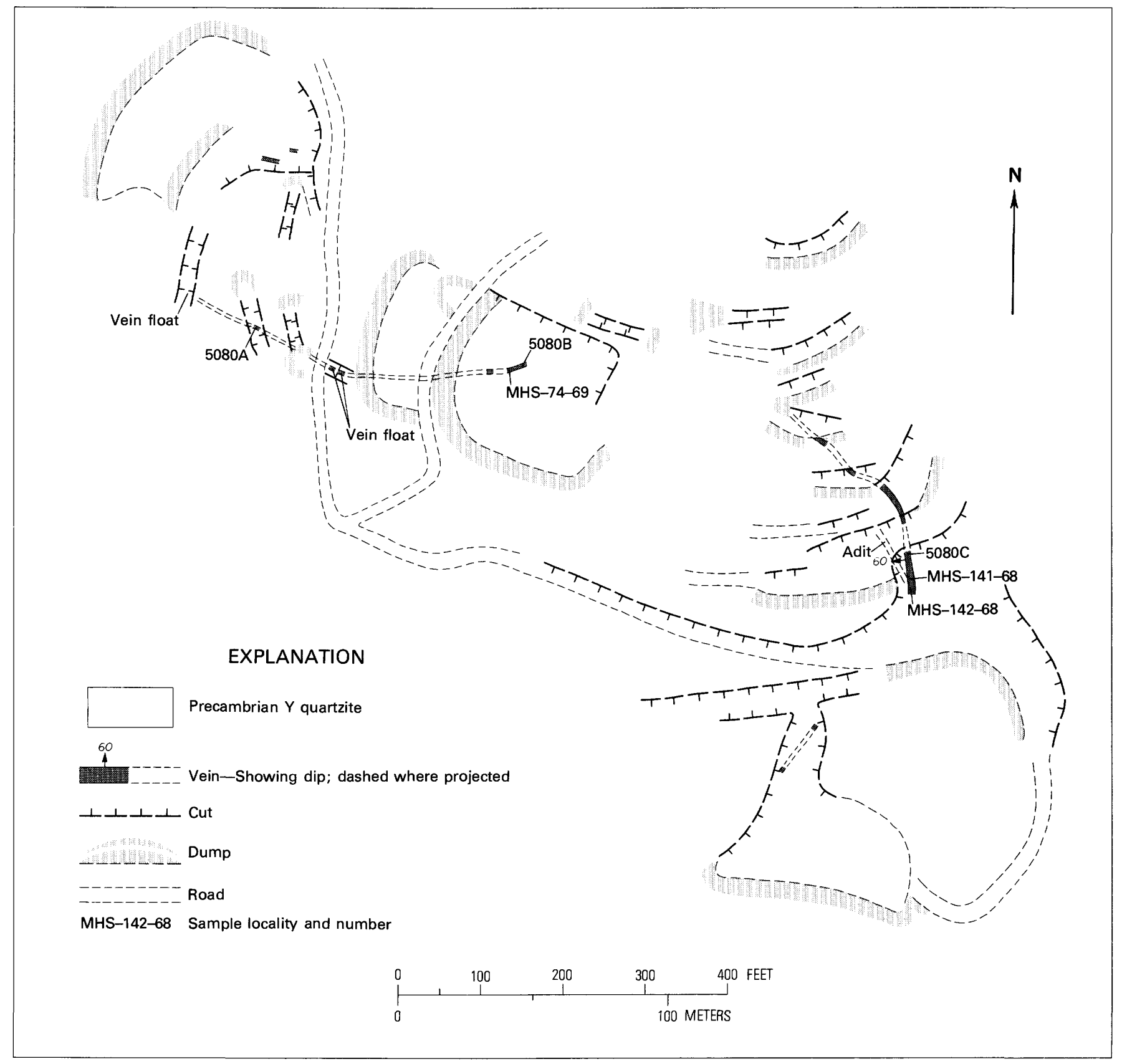

Figure 19.--Geologic map of the Buffalo property (loc. 18). Mapped by M. H. Staatz, 1973.

$\mathrm{ThO}_{2}$ and 0.46 percent total rare-earth oxides (Austin, 1968, p. 3).

West of the main vein is a second vein which strikes from about $\mathrm{S} .80^{\circ} \mathrm{W}$. to $\mathrm{N} .70^{\circ} \mathrm{W}$. and appears to dip steeply to the south. Much of the vein material in the western four trenches is float, but some of it appears to be essentially in place. The length of the vein as mapped is 430 feet. The thickness at the eastern end is $1.5-2.5$ feet. This vein is also dark brown and its principal gangue mineral is quartz. Some microcline is present as well as minor calcite. Black shiny plates of specularite are the common iron oxide. Magnetite and limonite are less common. Thorite was the only thorium mineral recognized. Other minerals include rutile and pyrite. Three samples taken from this vein range from 0.13 to 0.61 percent $\mathrm{ThO}_{2}$ (fig. 19, table 7).

Two other thorium-bearing veins are exposed in the northwestern most group of trenches (fig. 19). These veins strike about $\mathrm{N}$. $80^{\circ} \mathrm{W}$. The southern one dips $50^{\circ} \mathrm{SW}$., is exposed for approximately 20 feet, and is 2 feet thick. The northern one is exposed for about 10 feet and is about 1 foot thick. Both are dark brown and consist essentially of quartz and iron oxides. 


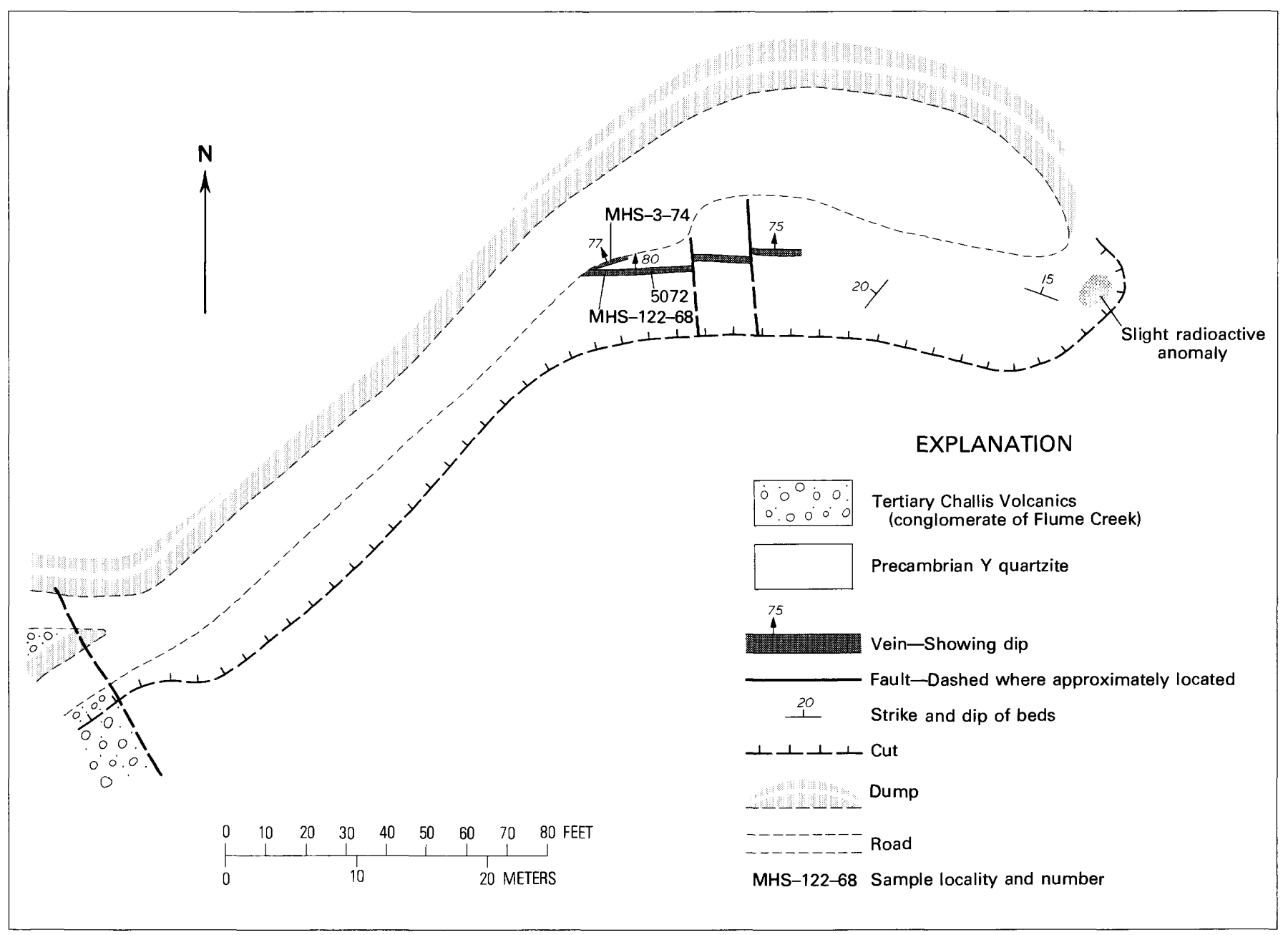

Figure 20.-Geologic map of the Black Bull No. 3 property (loc. 20). Mapped by B. J. Sharp and D. L. Hetland, 1965; revised by M. H. Staatz, 1973.

\section{BLACK BULL NO. 3}

The Black Bull No. 3 claim (loc. 20) lies on the south side of Agency Creek just west of the road leading south to the Copper Queen Mine. The vein is only about 30 feet above Agency Creek in the SW $1 / 4$ sec. 15 , T. 19 N., R. 25 E. The property was located by E. P. Peron in 1952 (Sharp and Cavender, 1962, p. 42). In August 1972 the property was owned by Nuclear Fuels and Rare Metals Corp. The country rock is an iron-oxide-stained micaceous quartzite of Precambrian $Y$ age. This red-stained quartzite is part of a zone a hundred to several hundred feet wide that can be traced for more than a mile along the east side of the Dan Patch fault. The workings on this property consist of a cut more than 290 feet long that has a wall as much as 20 feet high. A branching vein is exposed along the wall of the cut (fig. 20), where it is offset by two small faults. The main part of this vein is well exposed for 60 feet, and a radioactive spot near the east end of the cut indicates that it probably continues for at least 70 more feet. The possible extension of this vein is limited by two large faults, the Dan Patch fault 150 feet to the west (fig. 20), and the Bull Moose fault, approximately 200 feet to the east. This vein varies in thickness from 0.5 to 1.3 feet. It strikes N. $77^{\circ} \mathrm{W}$. and dips $75^{\circ}-80^{\circ}$ NE. The vein bifurcates near its west end (fig. 20), and the smaller branch strikes $\mathrm{N} .77^{\circ} \mathrm{E}$. and dips $77^{\circ} \mathrm{NW}$. This thinner branch is 2-6 inches thick and is exposed for only 5 feet.

Unlike most of the veins in this district, calcite is the principal gangue mineral; some white quartz is also present. Black shiny specularite is the principal iron oxide mineral, although hematite also occurs in a dark cherry-red granular form. Brown limonite is abundant, and black granular magnetite occurs in scant amounts. Radioactivity is due to dark-red thorite. Other minerals include white platy barite and cubes and pyritohedrons of brassy pyrite.

Two samples cut across the main part of the vein, one (MHS-122-68) 0.7 foot long and the other (5072) 1.25 feet 


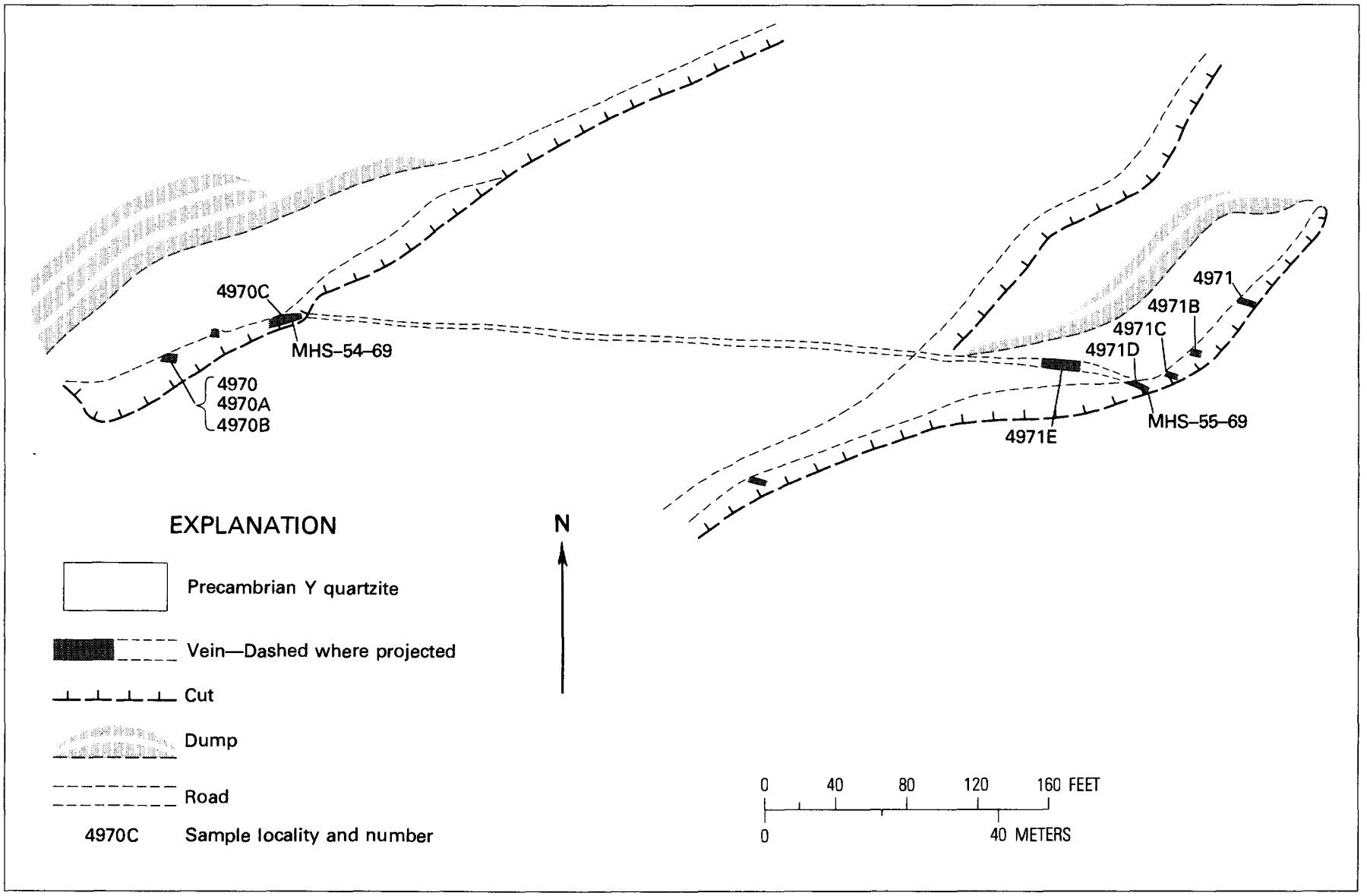

FigurE 21.-Geologic map of the Deer Fraction IA veins (loc. 21). Mapped by B. J. Sharp and D. L. Hetland, 1965; revised by M. H. Staat7. 1973.

long (fig. 20), yielded 0.80 and 0.72 percent $\mathrm{ThO}_{2}$, respectively. A third sample (MHS-3-74) from the thinner branch vein, 0.5 foot long, contained 0.24 percent $\mathrm{ThO}_{2}$.

\section{DEER FRACTION 1A}

A number of veins have been exposed on the eight Deer claims that lie along the south side of Agency Creek north of the Copper Queen mine. The largest of these lies on the Deer Fraction 1A claim (loc. 21), which is in the NW1/4 SE $1 / 4 \mathrm{sec}$. 15 , T. 19 N., R. 25 E., Boise meridian, Idaho. This claim is on a steeply dipping, north-facing, heavily vegetated slope, and the only exposures are found in deep cuts. The property was located May 15, 1955, by Jacob Schenk for Nuclear Fuels and Rare Metals Corp., who still owned it in the summer of 1972. This claim was explored by several long inclined roads. In the two areas where radioactivity was found, cuts deep enough to expose the veins were made. The westernmost cut (fig. 21) is about 300 feet long and has a back of as much as 20 feet; the easternmost one is about 350 feet long and has a back of as much as 12 feet. The country rock of Precambrian $\mathrm{Y}$ age is gray micaceous quartzite that contains some greenish siltite beds. The westernmost cut exposes three veins and the easternmost one five (fig. 21). Veins appear to occupy a broad shear zone and some appear to be lenticular. In the westernmost cut the principal vein thins from 10 feet thick near the base of the cut to 2.5 feet at the top of the cut. This vein (fig. 21) has an overall strike of about N. $87^{\circ} \mathrm{W}$. and dips $45^{\circ}-70^{\circ} \mathrm{SW}$. Its length between the two cuts is 520 feet. Along strike east of this claim radioactive vein material occurs in the rubble of another cut. If this is an extension of this vein, as seems probable, then this vein can be extended another 700 feet. The thickness of this vein is about $1-10$ feet and averages about 3 feet. In addition two other veins were exposed in the floor of the westernmost cut in 1965 but were later covered. Where exposed they were approximately 8 and 7 feet thick. They appear, however, to be short lenses along the main snear zone, as they are not exposed to the east in the back of the cut. In the easternmost cut three veins, 1.5, 4.0 , and 1.3 feet thick, lie north of the principal vein. In addition, a poorly exposed rather weakly radioactive vein lies about 80 feet south of the principal vein. Veins are brown to black and are made up principally of quartz and various iron oxides. Where the veins are brown, goethite is the chief iron oxide, and where they are black, specularite. In addition, all contain a minor amount of magnetite. Thorite 
TABLE 8.--Thorium analyses of chip samples from the Deer IA claim, Idaho

\begin{tabular}{|c|c|c|c|}
\hline Vein & Sample No. & $\begin{array}{c}\text { Sample length } \\
\text { (ft) }\end{array}$ & $\begin{array}{c}\mathrm{ThO}_{2} \\
\text { (percent) }\end{array}$ \\
\hline Principal & $\begin{array}{l}.4970 \mathrm{C} \\
\text { MHS-54-69 } \\
4971 \mathrm{D} \\
4971 \mathrm{E} \\
\text { MHS-55-69 }\end{array}$ & $\begin{array}{l}4.0 \\
3.0 \\
6.0 \\
7.0 \\
.4\end{array}$ & $\begin{array}{l}10.18 \\
2.19 \\
1.25 \\
1.34 \\
2.59\end{array}$ \\
\hline Subsidiary & $\begin{array}{l}.4970 \\
4970 \mathrm{~A} \\
4970 \mathrm{~B} \\
4971 \mathrm{C} \\
4971 \mathrm{~B} \\
4971\end{array}$ & $\begin{array}{l}2.4 \\
2.0 \\
2.4 \\
1.5 \\
4.0 \\
1.3\end{array}$ & $\begin{array}{r}1.35 \\
1.83 \\
1.73 \\
1.38 \\
1.08 \\
12.00\end{array}$ \\
\hline
\end{tabular}

'Wet chemical analysis by Lucius Pitkin, Inc., Grand Junction, Colo. 2Gamma-ray spectrometric analysis by C. M. Bunker and C. A. Bush, U.S.
Geological Survey, Denver, Colo.

was the only thorium mineral noted. In addition, there are minor amounts of calcite, rutile, feldspar, barite, and pyrite. The $\mathrm{ThO}_{2}$ content of five samples from the principal vein ranged from 0.18 to 0.59 percent (fig. 21 ; table 8 ). Six other samples, taken from the other veins, are shown in figure 21 and table 8 . They ranged from 0.08 to 2.0 percent $\mathrm{ThO}_{2}$.

\section{BLACK BEAR NO. 2}

This property (loc. 37) covers the nose of a small northward-trending ridge 6,000 feet south of the junction of Flume and Agency Creeks. It is about halfway between Agency Creek and the Continental Divide on a Douglas-fir-clad northward-facing slope in the E1/2NW1/4 sec. 21, T. 19 N., R. 25 E., Boise meridian, Idaho. The property is reached by a steep narrow road that meets the Agency Creek road about 0.25 mile east of the Flume Creek junction and ends at the property about 1 mile to the south. The Black Bear No. 2 was located by Earl Pyeatt and G. E. Shoup on May 14, 1954. This property was controlled by Nuclear Fuels and Rare Metals Corp. in 1961. Assessment work was done on it in 1971 by Nuclear Fuels and Golden Pleasures Mining Co. The Black Bear No. 2 was developed by a bulldozer cut 100 feet long having a 15-foot back, a small pit, and a branching road (fig. 22).

The country rock is a gray fine-grained micaceous quartzite (Precambrian Y). The workings on this property expose an undulating vein that strikes N. $45^{\circ} \mathrm{W}$. The dip is steep but is difficult to determine because the vein changes shape in the large cut. The vein has an exposed length of 135 feet. Thickness ranges from about 3 to 32.5 feet. In the back of the large cut the thickness ranges from 13 to 32.5 feet, and at the southeastern exposure of the vein (fig. 22) it ranges from 3 to 4 feet. In this same exposure a second vein was uncovered 2 feet to the west. This vein is 1 foot thick. Although from the one exposure it appears to be a separate vein or lens, it might be a branch of the main vein.

The principal vein is made up mainly of pink to white microcline. Quartz is only a minor accessory mineral. Most of the vein has thin irregular layers and patches of black shiny specularite. Some limonite is present, especially in the southeast part of the vein. In part, this mineral occurs as dark brown cubes, a pseudomorphous replacement of pyrite. The only other iron oxide mineral noted was magnetite, which occurs as small black granular crystals. Reddish-brown shiny thorite was the only thorium mineral noted. Barite is found as both white platy and clear pink crystals. In addition, this vein contains minor amounts of black shiny rutile, greasy greenish-white pyromorphite, and bright-yellow wulfenite. This was only one of three veins in this district in which molybdenum minerals were found, the others being the Barbara (loc. 172) and the Daisy Nielsen.

Six samples were taken from this vein and they contained from 0.02 to 0.26 percent $\mathrm{ThO}_{2}$ (fig. 22; table 9). In the thick northwest end of the vein the thorium is concentrated in the outer 3-4 feet of both the hanging and footwall sides. As both lead and molybdenum minerals were noted in several samples, one sample (MHS-133-68) was also analyzed for these elements and other base and precious metals. This sample had 0.024 percent molybdenum, 0.050 percent lead, 0.080 percent zinc, 0.0053 percent copper, 0.090 ounce per short ton of silver, and less than 0.0006 ounce per short ton of gold. This vein is noted for its very high microcline content and a sample (MHS-47-73) analyzed by gamma-ray spectrometer yielded 12.4 percent potassium. As microcline was the only potassium mineral noted, this amount of potassium would be equivalent to about 88 percent microcline.

\section{WONDER}

The Wonder vein (loc. 45) lies astride Camp Creek, 1.1 miles south-southeast of this creek's junction with Agency Creek, in the SE $1 / 4$ sec. 22, T. 19 N., R. 25 E., Boise meridian, Idaho. The property is 0.75 mile south of the Copper Queen mine, and the road to the Copper Queen mine from the Agency Creek road continues up Camp Creek to the Wonder property. The original location was made on five claims, then called the Wonder Lode and the Buckhorn mining claims, in about 1923 by James Quinn (Sharp and Cavender, 1962 , p. 44). Later the five claims were relocated as the Wonder Lodes Nos. 1-5 by Ray and Claire Pierce of Salmon, Idaho.

The vein is zoned, the west part containing copper, zinc,

TABLE 9.-Thorium analyses of chip samples from the Black Bear No. 2 claim, Idaho

\begin{tabular}{lcc}
\hline Sample No. & $\begin{array}{c}\text { Sample length } \\
(\mathrm{ft})\end{array}$ & $\begin{array}{c}\mathrm{ThO}_{2} \\
\text { (percent) }\end{array}$ \\
\hline 4998D & 3.5 & 10.20 \\
4998C & 25.0 & 1.04 \\
4998B & 4.0 & 1.26 \\
MHS-133-68 & 19.0 & 2.082 \\
4998A & 3.0 & 1.19 \\
MHS-47-73 & 3.0 & 2.02 \\
\hline
\end{tabular}

IWet chemical analysis by Lucius Pitkin, Inc.. Grand Junction, Colo. 'Gamma-ray spectrometric analysis by C.M. Bunker and C. A. Bush, U.S. Geological Survey, Denver, Colo. 
and a little thorium, and the central and eastern parts containing more thorium and a little copper and zinc. Early workings, which consisted of several pits and eight short adits, some not more than 20 feet long, were made on a small ridge west of Camp Creek and immediately adjacent to the east side of the creek. A little ore containing copper and zinc was shipped to the mill on the Copper Queen property (Sharp and Cavender, 1962, p. 44). In 1950, when interest shifted to thorium, the property was owned by G. E. Shoup of Salmon, Idaho (Trites and Tooker, 1953, p. 193). At this time six of the small adits were caved; the other two were 50 and 75 feet long. The property was leased to Frank Eichelberger and associates of Spokane, Wash., in October 1951, who turned all their rights over to Defense Metals, Inc. of Kellogg, Idaho (Sharp and Cavender, 1962, p. 44). In August 1952, the U.S. Defense Minerals Exploration Administration granted an exploration loan to Defense Metals, Inc., to aid in exploring for thorium. During this contract, which lasted until December 1954, 13 trenches, 2 adits, and 3 diamond-drill holes were made. The trenches form a zigzag pattern up 680 feet of the steep east face of Camp Creek canyon (pl. $2 A$ ). There are two adits, the lower one, 40 feet above the creek level on the east side of Camp Creek, which has 487 feet of workings, and the upper one, 120 feet above the first adit on the same side of the creek, which has 336 feet of workings. Three diamond-drill holes totaling 941 feet in length were drilled. In one hole the vein was not found, apparently cut out by a large fault. The other two cut the vein approximately 150 feet below the level of Camp Creek. Little work has been done since this contract terminated, and the tunnels have caved near their mouths and many of the trenches show considerable sloughing. From at least 1966 to 1972 , this property was owned by Nuclear Fuels and Rare Metals Co.

Most of this property is underlain by a Precambrian $Y$ dark-gray fine-grained micaceous quartzite. These rocks

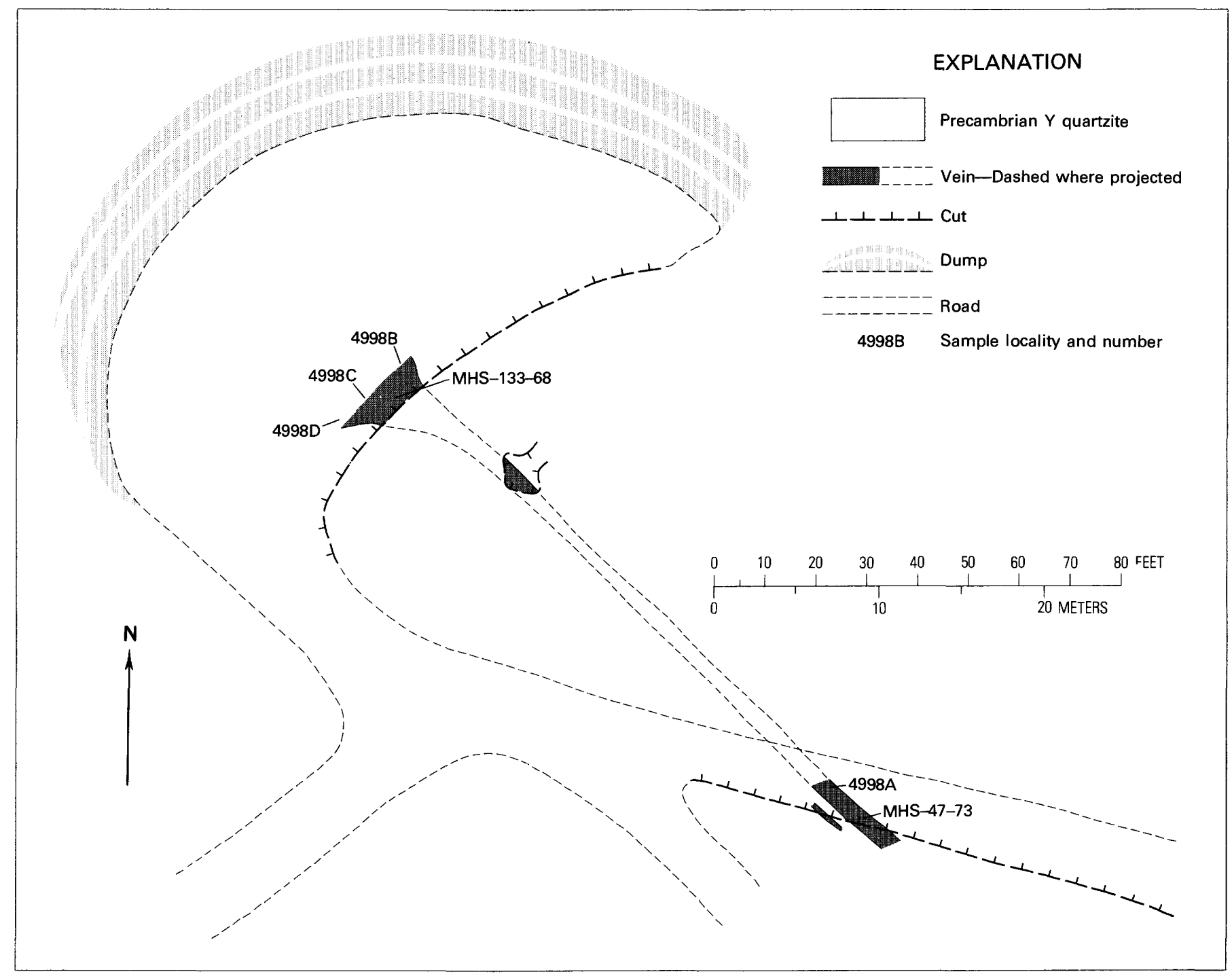

FIGURE 22.-Geologic map of the Black Bear No. 2 property (loc. 37). Mapped by B. J. Sharp and D. L. Hetland, 1965; revised by M. H. Staatz, 1973. 
have varying attitudes, striking from N. $30^{\circ} \mathrm{W}$. to N. $70^{\circ} \mathrm{E}$. and dipping $10^{\circ}-40^{\circ} \mathrm{N}$.; most, however, strike N. $50^{\circ}-70^{\circ} \mathrm{E}$. and $\operatorname{dip} 25^{\circ}-35^{\circ} \mathrm{NW}$. An east-west-trending shear zone cuts these quartzites and contains twr Tertiary diorite dikes in addition to the thorium veins. One diorite dike lies $40-80$ feet north of the principal vein, which it tends to parallel (pl. $2 A$ ). This dike has been traced for about 970 feet and is 5-20 feet thick. Its dip is nearly vertical near the east end and $58^{\circ} \mathrm{S}$. near the west end (Weis and others, 1958, p. 38). The second dike lies approximately 410 feet south of the east end of the main vein, which it parallels, and is exposed for 560 feet ( $\mathrm{pl}$. $2 A$ ). This dike is about 10 feet thick. Both dikes weather easily to a soft olive-green material and are exposed only in the deeper cuts. The diorite dikes vary somewhat in composition from place to place but in general contain about equal amounts of mafic minerals and plagioclase. The principal mafic minerals are generally either hornblende or augite, although in some places these have been largely altered to biotite. Minor amounts of epidote, chlorite, magnetite, quartz, clinozoisite, pyrite, and hematite are also present.

The thorium mineralization, for the most part, is localized in one large generally eastward-trending vein that dips $40^{\circ}-80^{\circ} \mathrm{S}$. The vein ranges in thickness from 0.7 to 10 feet and has an average thickness of a little less than 3 feet. Near the eastern end of the main vein a number of smaller veins or lenses, 0.5 inch to 2.0 feet thick, trend parallel to, or fan away from, its southern side ( $\mathrm{pl}$. $2 A$ ). The main vein can be traced for approximately 920 feet. To the west along a small gulch 235 feet west of Camp Creek, it ends abruptly on the large Dan Patch fault. Eastward it apparently ends against a small cross fault, although east of the fault it may be represented by one of several small veins. The main vein is exposed on the steep side of Camp Creek canyon through a vertical distance of 350 feet. Drilling extended its known vertical distance another 150 feet. As has been noted previously, the thorium veins, as well as the diorite dikes, occupy a wide shear zone. Shearing along this zone not only preceded the intorduction of the vein filling, but continued during and after its deposition. In many places early vein material was brecciated and a second generation of minerals was introduced along the fractures, followed by further fracturing. Not only was there fracturing along the shear zones, but several cross faults were noted that cut both the main vein and the northern diorite dike (p1. $2 A$ ). These faults have a northerly strike and a steep $\left(63^{\circ}-90^{\circ}\right)$ dip. Horizontal offset ranges from 8 to 25 feet. The country-rock quartzite is stained hematitic red adjacent to the veins and along some of the fractures in the shear zone. Locally the iron oxide-stained rock extends as much as several feet from the vein but in most places is only a few inches thick. The veins are generally brown and amorphous in appearance, containing irregular black layers and areas. For the most part, the veins are soft and friable. The mineralogy of the main vein varies from place to place. West of Camp Creek the chief gangue

\begin{tabular}{|c|c|c|c|c|c|}
\hline \multirow{2}{*}{$\frac{\text { Sample No. }}{\mathrm{MHS}-19-69^{1}}$} & \multicolumn{2}{|c|}{$\begin{array}{l}\text { Length of samples } \\
\text { and type } \\
\text { (ft.) }\end{array}$} & \multirow{2}{*}{$\begin{aligned} \begin{array}{c}\mathrm{ThO}_{2} \\
\text { (percent) }\end{array} \\
20.066\end{aligned}$} & \multirow{2}{*}{$\begin{array}{c}\begin{array}{c}\text { Copper } \\
\text { (percent) }\end{array} \\
30.42\end{array}$} & \multirow{2}{*}{$\frac{\begin{array}{c}\text { Zinc } \\
\text { (percent) }\end{array}}{33.70}$} \\
\hline & 2.0 & $\mathrm{Ch}$ & & & \\
\hline TEH-I & 1.5 & $\mathrm{C}$ & 4.19 & 5.35 & 5.28 \\
\hline TEH-2 & 1.5 & $\mathrm{C}$ & 41.10 & 5.15 & 5.21 \\
\hline TEH-3 & 1.5 & $\mathrm{C}$ & ${ }^{4} 1.00$ & 52.80 & 51.56 \\
\hline TEH-5 & 2.5 & $\mathrm{C}$ & 4.30 & 5.45 & 53.46 \\
\hline TEH-4 & 2.0 & $\mathrm{C}$ & ${ }^{4} .26$ & 51.05 & 53.40 \\
\hline TEH-6 & 2.5 & $\mathrm{C}$ & 42.5 & 5.15 & 5.29 \\
\hline MHS-60-696 & 9.8 & $\mathrm{C}$ & 2.34 & 3.44 & 3.40 \\
\hline $5069 \mathrm{~B}$ & 6.0 & $\mathrm{C}$ & 7.34 & N.d. & N.d. \\
\hline TEH-7 & 2.5 & C & ${ }^{4} .50$ & ${ }^{5} .65$ & 5.26 \\
\hline $5069 \mathrm{~A}$ & 3.0 & $\mathrm{C}$ & 7.54 & n.d. & n.d. \\
\hline $5069 \mathrm{C}$ & 2.0 & $\mathrm{C}$ & 7.15 & n.d. & n.d. \\
\hline $5069 \mathrm{D}$ & 2.0 & $\mathrm{C}$ & 72.14 & n.d. & n.d. \\
\hline TEH-8 & 2.0 & $\mathrm{C}$ & 4.07 & 5.20 & 5.08 \\
\hline $5069 \mathrm{E}$ & 1.0 & $\mathrm{C}$ & 71.47 & n.d. & n.d. \\
\hline MHS-59-69 & 0.7 & $\mathrm{C}$ & 3.34 & n.d. & n.d. \\
\hline
\end{tabular}

1 This sample also contains 0.012 percent lead. 0.99 ounce/ton silver, and 0.0058 ounce ton gold. Atomic absorption analysis. U. S. Geological Survey, Denver. Colo.

'Gamma-ray spectrometer analysis by C. M. Bunker and C. A. Bush. U.S. Geological Survey, Denver, Colo.

A tomic absorption analysis. U.S. Geological Survey, Denver, Colo.
eThO calculated from eU and U analyses by the U.S. Geol. Survey and U.S. Bureau of Mines. respectively.

'Analyses by U.S. Bureau of Mines, Albany, Oreg. Atomic absorption analysis, U. S. Geological Survey. Denver, Colo.

Wet chemical analysis by Lucius Pitkin. Inc., Grand Junction, Colo.

minerals are quartz and calcite; sphalerite and copper minerals are relatively abunant. This is the part of the vein developed in the early days for copper. East of the creek, especially high on the slope, calcite and siderite are the most abundant gangue minerals and barite is fairly common. Sphalerite is present but less common than to the west. Reddish-brown thorite is more abundant on the east side of the valley. Limonite and black manganese oxide minerals are ubiquitous, generally occupying fractures cutting the earlier formed minerals. Specularite and magnetite are less common. Chalcopyrite is the chief copper mineral, but minor chrysocolla, malachite, and azurite are found coating fractures. Other sulfides identified are pyrite and pyrrhotite. Minor amounts of microcline, apatite, and rutile also occur in this vein.

The veins on the Wonder property have been sampled many times. Sixteen samples collected by Sharp and Cavender (1962, p. 62, pl. 5) and by Trites and Tooker (1953, p. 195) contained $0.02-3.2$ percent $\mathrm{ThO}_{2}$. The location of 16 other surface samples is shown on figure 23 . These samples contained $0.066-2.5$ percent $\mathrm{ThO}_{2}$ (table 10). Although the two long adits (pl. 2A) financed by the U.S. Defense Minerals Exploration Administration loan were sampled, data on individual samples is not available. A summary of these data, however, is given by Weis, Armstrong, and Rosenblum (1958, p. 38) who state: "The upper working exposes brecciated vein material for more than 100 feet averaging 2.5 feet in thickness and containing about 0.75 percent thorium oxide. In the lower working, vein material exposed for 150 feet averages 1.75 feet in thickness and contains about 0.30 percent thorium oxide." Ten copper and 
zinc analyses were made of the main vein (table 10 ). The copper content ranged from 0.15 to 2.80 percent; the zinc content, which ranged from 0.08 to 3.70 percent, is highest in the western and central parts of the vein. Two samples analyzed for silver contained 0.52 and 0.99 ounce per short ton, suggesting that this element could be an important economic consistuent of this vein. Only minor amounts of lead and gold are present in the two samples analyzed for this element (table 10).

\section{CAGO NO. 12}

This property (loc. 49) lies 0.3 mile north of the Continental Divide on a steep north-facing Douglas-fir-covered slope in the NE $1 / 4 \mathrm{sec} .28$ and NW1/4 $\mathrm{sec}$. 27, T. 19 N., R. 25 E., Boise meridian, Idaho. It is reached from the Agency Creek road by following a twisty secondary road that connects the mouth of Camp Creek to the Continental Divide. A second road leads west from this road at a point 3.2 miles from Agency Creek, for 0.8 mile to the property. The original locators are not known, but in 1957 this property was owned by the Salmon Uranium and Thorium Co. (Anderson, 1958, p. 73). Since then it has been controlled by the Rare Metals Corp. (a subsidiary of El Paso Natural Gas Co.) in 1961; the Agency Creek Thorium and Rare Metals Co. of Salmon, Idaho, in 1966; and the Nuclear Fuels and Rare Metals Corp. of Salmon in 1972.

Workings consist of a series of interconnecting bulldozer cuts and trenches that blanket the hillside for a distance of 2,700 feet, and one 120-foot-long adit (pl. 2E). These workings are cut in a Precambrian $Y$ gray fine-grained micaceous quartzite. The vein on the Cago No. 12 is the westernmost known vein of many that lie along a northwest-trending shear zone. This shear zone can be traced for 2.5 miles across the Continental Divide to the Dan Patch fault. Other veins in this same shear zone include the Contact vein, Beaverhead vein, Trapper No. 1 vein, and Shear Zone vein.

The vein on the Cago No. 12 property strikes N. $45^{\circ}-55^{\circ}$ W. and dips $45^{\circ}-55^{\circ} \mathrm{SW}$. It has been traced for 2,625 feet and is $0.2-25$ feet thick. The thickest and also most radioactive part of the vein is about 690 feet long. This part, which is $10-16$ feet thick, extends from 270 feet southeast of the adit to 420 feet northwest of it. The northwestern part of this vein varies from 0.2 to 10 feet in thickness. The vein varies both in color and in mineralogy. In the thicker part near the adit it is yellowish brown and appears to be mainly brown jasper. Actually, the color and texture are produced by the intermixing of fine-grained quartz with tiny particles of limonite. In some places farther northwest, the vein is white and made up mainly of quartz; in other places it is reddish brown due to a high content of hematite. In the thickest part, tan microcline is also an important gangue mineral. At least part of the limonite is goethite, and some of the goethite occurs as small dark-brown cubes, a
TABLE 11.-Thorium analyses of chip samples from the Cago No. 12 vein, Idaho

\begin{tabular}{lcc}
\hline Sample No. & $\begin{array}{c}\text { Sample length } \\
\text { (ft) }\end{array}$ & $\begin{array}{c}\text { Tho, } \\
\text { (percent) }\end{array}$ \\
\hline MHS-30-69 & 1.0 & 10.12 \\
4976C & 2.0 & 2.03 \\
4976A & 2.5 & 2.11 \\
4976B & 2.0 & 2.02 \\
4976D & 8.0 & 2.05 \\
4976E & 4.0 & 2.16 \\
MHS-28-69 & 13.0 & 1.085 \\
MHS-29-69 & 12.0 & 1.29 \\
\hline 'Gamma-ray spectrometric analysis by C. M. Bunker and C. A. Bush. U.S. \\
Geological Survey, Denver, Colo. \\
2Wet chemical analysis by Lucius Pitkin, Inc., Grand Junction, Colo.
\end{tabular}

pseudomorphous replacement of pyrite. Other iron oxide minerals are specularite, which is common in many samples, and minor amounts of black magnetite. The chief thorium mineral is reddish-brown shiny thorite; minor amounts of monazite and allanite are present. In addition, $\tan$ to pale-orange rutile, white a patite, clear to pale-orange barite, and a few crystals of pyrite, galena, and chalcopyrite were also noted. Eight samples were taken along this vein by the U.S. Atomic Energy Commission and the U.S. Geological Survey (pl. 2E). These range in $\mathrm{ThO}_{2}$ content from 0.02 to 0.29 percent (table 11 ).

\section{CONTACT}

The Contact (loc. 52) is a name applied to one major vein having several branches, or to several veins, that lie along the Continental Divide on the north side of North Frying Pan Creek (pl. $2 \mathrm{C}$ ). The ridge here has a N. $75^{\circ} \mathrm{W}$. trend, and the principal vein lies more or less parallel to the ridge and just on the Idaho side, although one branch and nearby parallel veins lie on the Montana side. These veins are in sec. 27, T. 19 N., R. 25 E., Boise meridian, and secs. 19 and 20, T. 10 S., R. 15 W., Montana Principal Meridian. The property can be reached from Lemhi Pass by following the road south along the Continental Divide for 3.2 miles. The principal workings are on the Contact Nos. 1 and 2 claims, which in the early 1960's were part of the Nuclear Fuels and Rare Metals Corp. holdings. In 1972 the assessment work on these two claims was done by the Jan Corp. On the east end of the vein in Idaho is the Beaverhead claim, which was held in 1972 by Nuclear Fuels and Rare Metals Corp. The western end of this vein system, which was discovered much later than the rest of the vein, is covered by the Jan claims which were located in May 1967 by D. L. Davidson and Jacob Schenk. The Jan Corp. also did the assessment work on these in 1972. On the Montana side of the divide, the area is covered principally by the Ragand Nos. 8 and 10 claims. These claims were located in July 1957 by R. A., Ned, Billy, and Dave Wellborn. In 1973 they were part of the holdings of Sawyer-Adecor International, Inc. The veins in this area are 
explored by a series of bulldozer trenches (pl. $2 C$ ). On the Idaho side, most are relatively short trenches as much as 10 feet deep, and on the Montana side many are long, relatively shallow trenches.

The country rock consists principally of gray fine-grained micaceous quartzite and some interbeds of gray siltite (Precambrian Y). The Contact and adjacent veins (pl. 2C) are along a well-developed shear zone trending N. $70^{\circ} \mathrm{W}$. that contains many large and small veins, including the Cago No. 12, Beaverhead, Trapper No. 1, and Shear Zone veins. The main Contact vein follows an undulating fracture system. Strike of the vein measured at various places ranges from N. $45^{\circ}$ W. to N. $70^{\circ}$ E. and its dip from $25^{\circ}-60^{\circ} \mathrm{S}$. Near the east-central part, the vein apparently splits, and has one branch on each side of the Continental Divide fence. In places as near as the west end of the vein, several parallel veins are exposed in the trenches, and some of the projections shown on the map (pl. 2C) may actually connect two parallel veins. Small cross faults may also account for some of the offset of alinement between various segments of the main vein. The overall length of the principal vein is 1,940 feet. Measured thicknesses of the main vein varied from 0.5 to 10 feet.

Vein material varies from brown to black. Quartz is the principal gangue mineral except near the eastern end where pink microcline is the most abundant mineral. Hematite, which occurs both as black shiny plates of specularite and as granular grains, is common in much of this vein. The other principal iron oxide is brown goethite that commonly fills irregular fractures cutting earlier formed minerals. In some places the goethite occurs in pyritohedrons as a pseudomorphous replacement after pyrite. A few grains of black magnetite may be present. Brownish-orange to tan granular monazite is the principal thorium mineral; red shiny thorite also occurs in most specimens. In addition, most parts of this vein generally contain a little brown shiny rutile and a few brassy pyritohedrons of pyrite. Eight samples were taken along the main vein and they ranged

\section{TABLE 12.-Thorium analyses of samples from the Contact and adjacent veins, Idaho and Montana \\ [C, chip sample; G. grab sample; N.d. not determined]}

\begin{tabular}{lcc}
\hline Sample No. & $\begin{array}{c}\text { Sample length and type } \\
\text { (ft) }\end{array}$ & $\begin{array}{c}\text { ThO } \\
\text { (percent) }\end{array}$ \\
\hline MHS-23-69 & $2.0 \mathrm{C}$ & 10.046 \\
5061E & $3.5 \mathrm{C}$ & 2.38 \\
MHS-20-69 & $1.3 \mathrm{C}$ & 1.12 \\
MHS-17-69 & $16.0 \mathrm{C}$ & 1.17 \\
5061F & $4.0 \mathrm{C}$ & 2.23 \\
MHS-21-69 & N.d. G & 1.029 \\
AO-440 & $6.0 \mathrm{C}$ & 21.39 \\
MHS-16-69 & $2.5 \mathrm{C}$ & 1.86 \\
506IG & $2.5 \mathrm{C}$ & 21.40 \\
5061A & $3.0 \mathrm{C}$ & 2.20 \\
\hline
\end{tabular}

'Gamma-ray spectrometric analysis by C. M. Bunker and C. A. Bush. U.S. ${ }^{2}$ Wet chemical analysis by Lucius Pitkin, Inc., Grand Junction, Colo. from 0.029 to 1.40 percent $\mathrm{ThO}_{2}$ (pl. $2 C$; table 12). In addition, a sample (MHS-23-69) taken of a vein adjacent to the west end of the main vein yielded 0.046 percent $\mathrm{ThO}_{2}$, and another sample (5061 A) taken from a vein about 350 feet south of the main vein contained 0.20 percent $\mathrm{ThO}_{2}$.

\section{BEAVERHEAD, MONTANA}

The Beaverhead vein (loc. 64) lies about halfway up the north slope of North Frying Pan Creek valley in the SW1/4 sec. 20 , T. 10 S., R. 15 W., Montana Principal Meridian. It is about 0.5 mile north of the Last Chance vein, a few hundred feet northwest of the Trappers No. 1 vein, and 0.1 mile south of the Continental Divide. A road to this property splits off the Continental Divide road 0.25 mile east of this vein and rejoins it 0.5 mile northwest of it. The original claim on this vein was the Lucky Strike No. 1, which was located by R. G. Denny of Salmon, Idaho, in about 1950 (Trites and Tooker, 1953, p. 196). The vein was relocated in 1954 as the Montana Beaverhead by R. G. and Everett Denny, and from at least 1965-1972 this property has been owned by Nuclear Fuels and Rare Metals Corp. In 1973 assessment work on this property was done by Charles B. Kane. Workings consist of a road along the southern part of the vein, a broad area above this road some 280 by 40 feet where the vein has been scraped free of overburden, and a cut, 630 feet long, 55 feet above the road (fig. 23). Country rock is a Precambrian Y gray fine-grained sericitic quartzite.

The Beaverhead is one of many veins that lie along a $\mathrm{N}$. $66^{\circ} \mathrm{W}$.-trending shear zone that can be traced for 2.6 miles westward from the Dan Patch fault. This shear zone is fairly broad, and some veins are en echelon. Other well-known veins in this zone are the Cago No. 12, Contact, Trapper No. 1 , and Shear Zone veins. Because many veins are found on this hillside and the extent of the Montana Beaverhead claim is poorly known, the following discussion is confined to the principal vein on this property. The Beaverhead vein strikes about N. $80^{\circ} \mathrm{W}$. and dips $50^{\circ} \mathrm{SW}$. Near its southeast end the vein terminates on a fault that strikes N. $87^{\circ} \mathrm{W}$. and dips $46^{\circ}$ SW. Although slickensides on the vein indicate postvein movement, the abrupt thickening of the vein adjacent to the tault points to the fault acting as a dam to the vein fluids. This vein can be traced in almost unbroken outcrop for 520 feet. The vein is 9 feet thick at its northwestern exposure, but adjacent to the fault it abruptly thickens to about 25 feet.

The Beaverhead is a tan to medium-brown limonitic vein having quartz as its principal gangue mineral. Tan microcline is moderately abundant and these minerals are veined and crisscrossed by iron oxides, chiefly goethite and specularite. Some red granular hematite and a trace of magnetite also are found. Reddish-brown shiny thorite is the principal thorium mineral. Some thorium occurs in orangish-brown granular monazite. Other minerals noted are light-brown shiny rutile, brassy pyrite, muscovite, 


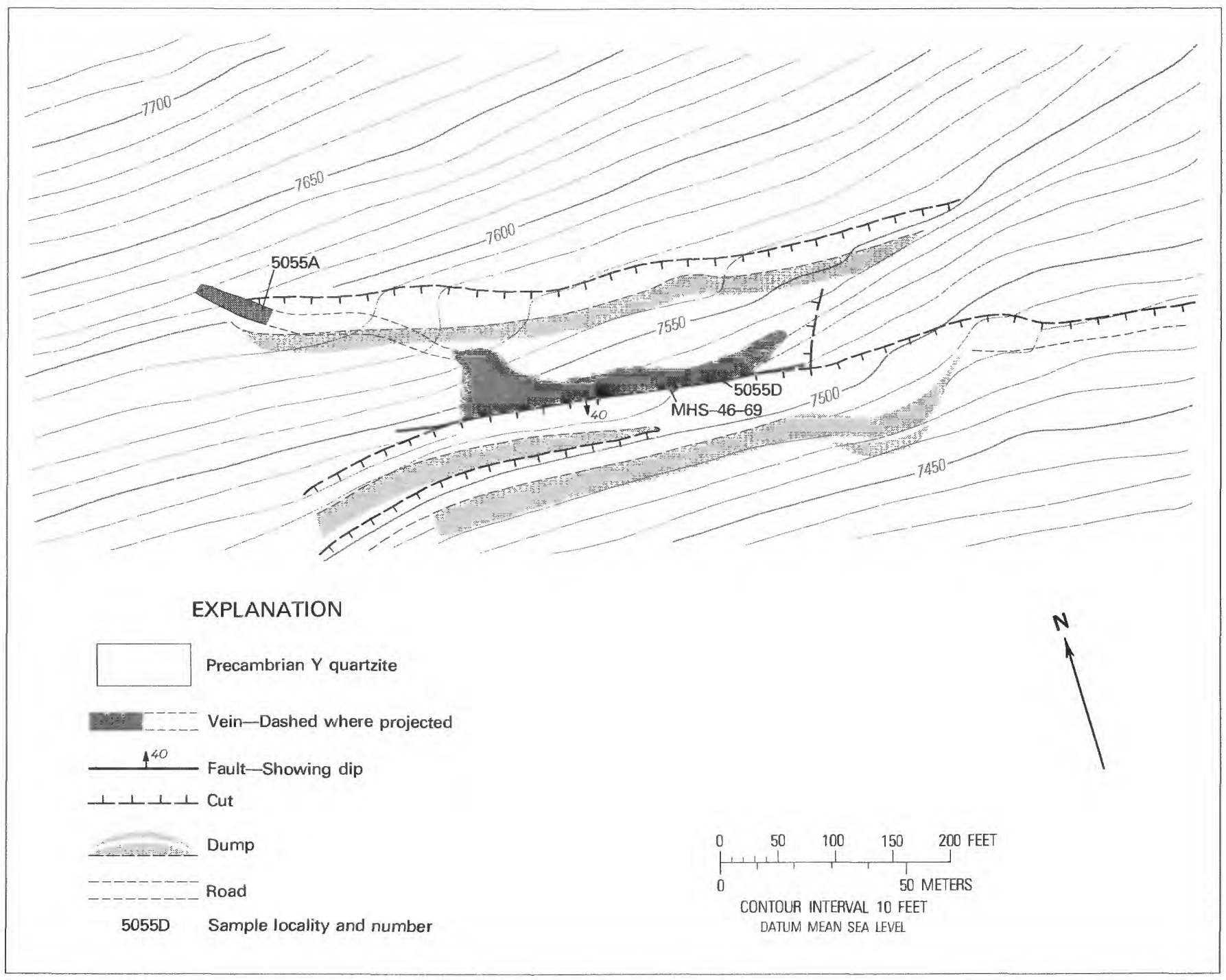

Figure 23.-Geologic map of the Beaverhead, Mont.,vein (loc. 64). Mapped by B. J. Sharp and D. L. Hetland, 1965; revised by M. H. Staatz, 1974.

apatite, and barite. Three samples from this vein yielded 0.24-0.53 percent $\mathrm{ThO}_{2}$ (fig. 23; table 13). In addition, one sample (MHS-46-69) was analyzed for precious metals; it contained 0.020 ounce of silver per short ton and no detectable gold (less than 0.0006 ounce per short ton).

\section{WONDER NO. 18}

The Wonder No. 18 property (loc. 70) is on the Idaho side of the Continental Divide in the NW1/4NW1/4 sec. 26, T. 19 N., R. $25 \mathrm{E}$. It lies along the top of a northwest-trending ridge near the junction of the ridge with the divide. Two thorium-bearing veins and one barren quartz vein are exposed on this property. These veins are within several hundred feet of the large northeast-trending Dan Patch fault. This property was controlled by Nuclear Fuels and
Rare Metals Corp. in August 1972. The three veins are exposed by more than a dozen bulldozer trenches (fig. 24). Country rock is a Precambrian Y gray sericitic quartzite. The two thorium-bearing veins have a northwesterly strike and are generally parallel to the Dan Patch fault; the quartz vein, on the other hand, has a northeasterly strike.

The best exposed thorium-bearing vein can be traced for about 550 feet. Near its southeast end it splits into two veins that diverge at an acute angle. This vein ranges in thickness from 0.7 to 1.2 feet in the northwestern group of trenches and from 1.5 to 2.0 feet in the southeast group before the split. The two bifurcated veins are each about 1 foot in thickness. The strike of this vein varies somewhat along its length, but its overall strike is $\mathrm{N} .70^{\circ} \mathrm{W}$. Dip also varies, but ranges from about $50^{\circ}-65^{\circ} \mathrm{SW}$. This vein consists chiefly of black granulated quartz and hematite. The black color is due to 
TABLE 13.-Analyses of samples from the Beaverhead, Mont. vein

[C. chip sample; G, grab sample; NA, not applicable]

\begin{tabular}{lcc}
\hline Sample No. & $\begin{array}{c}\text { Sample length } \\
\text { and type } \\
\text { (ft) }\end{array}$ & $\begin{array}{c}\mathrm{ThO}_{2} \\
\text { (percent) }\end{array}$ \\
\hline 5055A & NA G & 10.24 \\
MHS-46-69 & $6.0 \mathrm{C}$ & 2.48 \\
5055D & NA G & 1.53
\end{tabular}

IWet chemical analysis by Lucius Pitkin, Inc., Grand Junction. Colo.

'Gamma-ray spectrometric analysis by C. M. Bunker and C. A. Bush, U.S Geological Survey, Denver. Colo.

hematite, which occurs here only as specularite. Red enameloid thorite is the principal thorium-bearing mineral. A little tan granular monazite also occurs. Minor amounts of the following minerals are present: magnetite, muscovite, rutile, barite, pyrite, and a patite. Four samples taken along this vein yielded 0.21-1.21 percent $\mathrm{ThO}_{2}$ (fig. 24; table 14).

The second thorium-bearing vein is exposed only in the bottom of one trench 220 feet north of the vein just discussed (fig. 24). This vein is a pproximately 1 foot thick and its strike across the trench is $\mathrm{N} .75^{\circ} \mathrm{W}$. Vein material is dark brown and the principal gangue mineral is quartz. Radioactivity of this vein was measured at approximately 400,000 counts per minute with a Geiger counter.

The nonradioactive quartz vein lies south of the two thorium-bearing veins and crops out at the top of the hill (fig. 24). This vein has an overall strike of N. $70^{\circ} \mathrm{E}$. and a dip of $78^{\circ} \mathrm{SE}$. It parallels another nonradioactive quartz vein which lies about 400 feet to the south, on the Montana side of the Continental Divide (pl. 1). The quartz vein on the Wonder No. 18 claim can be traced for 285 feet and is 7-10 feet thick. The vein is white to purple and consists mainly of quartz, with hematite scattered along shear planes in the quartz.

\section{LITTLE DANDY}

The Little Dandy claim (loc. 72) is on the Idaho side of the Continental Divide in the NW1/4NW1/4 sec. 26, T. 19 N., R. 25 E. The workings lie adjacent to the road along the divide, and although not exposed on the Montana side, the vein is exposed within 25 feet of the boundary. The Little Dandy

TABLE 14.-Analyses of samples from the Wonder No. 18 claim, Idaho

[C. chip sample; G, grab sample; NA, not applicable]

\begin{tabular}{lcr}
\hline Sample No. & $\begin{array}{c}\text { Sample length } \\
\text { and type } \\
\text { (ft) }\end{array}$ & $\begin{array}{c}\mathrm{ThO}_{2} \\
\text { (percent) }\end{array}$ \\
\hline MHS-10-69 & $1.0 \mathrm{C}$ & 10.22 \\
MHS-9-69 & NA G & 1.33 \\
649 & $2.0 \mathrm{C}$ & 21.21 \\
650 & $1.5 \mathrm{C}$ & 2.21
\end{tabular}

'Gamma-ray spectrometric analysis by C. M. Bunker and C. A. Bush, U.S, Geological Survey, Denver, Colo.

${ }^{2}$ Wet chemical analysis by Lucius Pitkin, Inc., Grand Junction, Colo vein is about 650 feet southwest of the principal thorium-bearing vein on the Wonder No. 18 property and about 100 feet southwest of the Dan Patch fault. The claim was located June 9, 1955, by James Thompson, Carroll Wells, and Jacob Schenk. In August 1972, it was owned by the Nuclear Fuels and Rare Metals Corp. Workings made over a period of years consist of six intersecting trenches (fig. 25) as much as 90 feet long. The trenches cut Precambrian Y gray sericitic quartzite.

One vein, which has an overall strike of N. $78^{\circ} \mathrm{W}$. and a nearly vertical dip, is exposed in these trenches. The vein can be traced for 95 feet and has a thickness of 1.0-2.5 feet. It occupies a shear zone and is brecciated. The vein is dark brown and consists chiefly of iron oxide-stained microcline intermixed with goethite. Other iron oxides include minor specularite, magnetite, and reddish-brown hematite. Thorite was the only thorium mineral identified. Minor amounts of muscovite, pyrite, and fluorite also were noted. A 2.5-foot chip sample (MHS-8-69) taken across the east end of the vein (fig. 25) contained 0.047 percent $\mathrm{ThO}_{2}$.

\section{BLACK ROCK, MONTANA}

The Black Rock property (loc. 75) is in Montana in the E1/2 sec. 21, T. $10 \mathrm{~S} .$, R. $15 \mathrm{~W}$. This property lies along the north side of North Frying Pan Creek near its junction with South Frying Pan Creek. Access to the workings is along a southeast-trending road which branches from the Continental Divide road. The property is about 0.5 mile from the Continental Divide. Two veins, a long northwest-trending one and a short northeast-trending one, are found on this property. Part of the northwest-trending vein cropped out on the surface, and the first prospect was dug on it near the turn of the century. The principal vein was located for thorium as the Radio claim in 1949 by R. A. Wellborn of Armstead, Mont., and Frank Stocker of Medicine Lodge, Mont. (Sharp and Cavender, 1962, p. 39-40). The veins are on Montana State land and in the 1960's were leased to Harry Katseanes of Blackford, Idaho, and called the Black Rock. On the shorter vein, at the southeast end of the area, two claims were filed in June 1973. They are the K. and G. No. I and K. and G. No. 2, staked by Harry Katseanes and A. E. Granger of Salt Lake City, Utah. By 1952 Wellborn and Stocker had exposed the longer vein in two shallow bulldozer trenches about 200 feet apart. By 1965 a complex group of interconnecting bulldozer trenches exposed about 420 feet of the central part of the northwest-trending vein and a 210-foot trench exposed 120 feet of the northeast-trending vein (pl. $2 G$ ). The country rock is gray fine-grained sericitic quartzite (Precambrian Y) which, for the most part, strikes west to northwest and dips $20^{\circ}-50^{\circ} \mathrm{N}$. and NE.

The larger vein has an overall strike of No. $47^{\circ} \mathrm{W}$. and dip of $70^{\circ}-75^{\circ} \mathrm{SW}$. This vein has been traced in workings and by anomalous soil radioactivity for 1,610 feet on the north side 


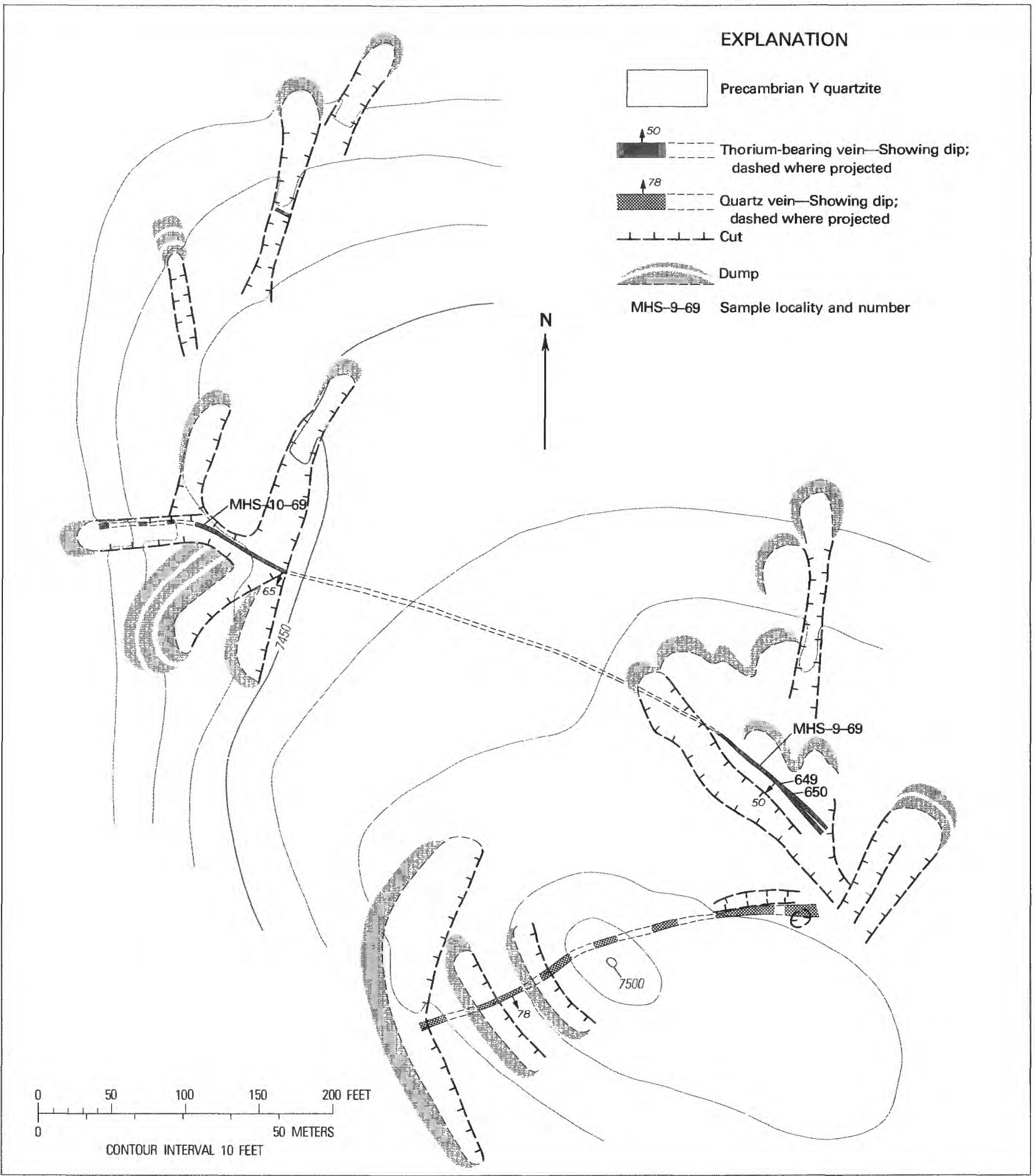

Figure 24.-Geologic map of the Wonder No. 18 property (loc. 70). Mapped by B. J. Sharp and D. L. Hetland, 1965, revised by M. H. Staatz, 1973. 


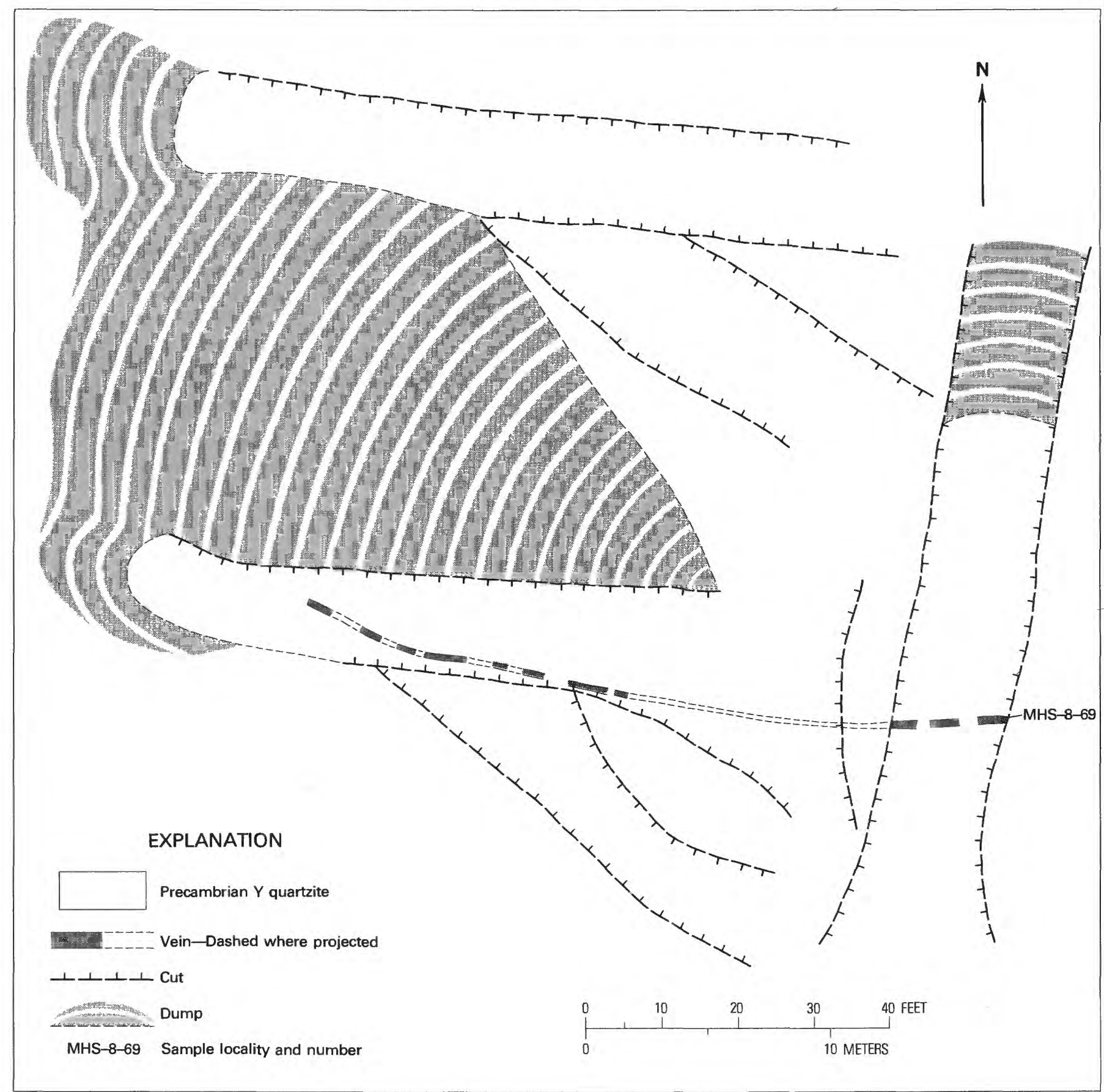

Figure 25.-Geologic map of the Little Dandy Vein (loc. 72). Mapped by B. J. Sharp and D. L. Hetland, 1965; revised by M. H. Staat7., 1973.

of North Frying Pan Creek (pl. 2G). Along the strike of this vein, on the ridge on the southeast side of Frying Pan Creek, is a vein on the Bull Moose claim (loc. 76, pl. 1). If the Bull Moose is a continuation of the long Black Rock vein, as seems likely, then it extends another 1,600 feet. In the principal workings the northwest-trending vein ranges from 1.3 to 6 feet in thickness. The vein on the Bull Moose property is only $0.1-0.3$ feet thick. The large northwest-trending vein is sheared, but not as intensely as most veins in this area. Furthermore, limonite, although present, is not as 
TABLE 15.- Thorium analyses of samples from the Black Rock. Mont. property

[C. chip sample; $G$, grab sample; $\mathrm{CH}$, channel sample; NA, not applicable]

\begin{tabular}{|c|c|c|c|}
\hline Vein & Sample No. & $\begin{array}{l}\text { Sample length } \\
\text { and type } \\
\text { (ft) }\end{array}$ & $\begin{array}{c}\mathrm{ThO}_{2} \\
\text { (percent) }\end{array}$ \\
\hline \multicolumn{4}{|l|}{ Northwest- } \\
\hline \multirow{7}{*}{ trending...... } & 644 & $6.0 \mathrm{C}$ & '0.82 \\
\hline & 645 & $4.0 \mathrm{C}$ & 1.70 \\
\hline & $5064 \mathrm{~A}$ & $3.5 \mathrm{C}$ & 1.63 \\
\hline & $5070 \mathrm{~A}$ & NA G & ${ }^{1} .69$ \\
\hline & $5070 B$ & $4.0 \mathrm{C}$ & 13.10 \\
\hline & $5070 \mathrm{C}$ & $3.0 \mathrm{C}$ & 1.68 \\
\hline & MHS-63-68 & $1.3 \mathrm{C}$ & 22.19 \\
\hline \multicolumn{4}{|l|}{ Northeast- } \\
\hline trending. . . . . . & $4972 \mathrm{~A}$ & $1.0 \mathrm{C}$ & 1.44 \\
\hline & 4972B & $1.0 \mathrm{C}$ & 1.38 \\
\hline & $4972 \mathrm{C}$ & $1.0 \mathrm{C}$ & 1.44 \\
\hline & MHS-62-68 & $.7 \mathrm{CH}$ & 21.70 \\
\hline
\end{tabular}

'Wet chemical analysis by Lucius Pitkin, Inc., Grand Junction, Colo. 2Gamma-ray spectrometric analysis by C. M. Bunker and C. A. Bush, U.S. Geological Survey, Denver, Colo.

common as in most veins and does not mask most of the minerals in the vein. The vein is irregularly banded, having layers of white coarsely crystalline quartz interspersed with layers of dark-brown limonite and black manganese oxides. Other minerals recognizable in hand specimens include a little microcline, barite, apatite, thorite, monazite, and chrysocolla. Although monazine occurs in many veins in this district, this vein was the only one in which monazite was noted in hand specimen. Other minerals, identified in mineral separates, are brockite, rutile, magnetite, and specularite. In addition, a little malachite was also identified by Sharp and Cavender (1962, p. 40). The $\mathrm{ThO}_{2}$ content of seven samples (pl. $2 G$; table 15 ) ranged from 0.63 to 3.10 percent. One sample (MHS-63-68) contained 0.23 ounce per short ton of silver, 0.15 percent copper, 0.023 percent lead, and 1.10 percent zinc. Compositionally this vein is similar to the Wonder, as both are rich in manganese oxides and in addition contain silver, zinc, copper, and lead.

The shorter vein, which apparently splits off the larger vein, has a strike of $\mathrm{N} .75^{\circ} \mathrm{E}$. and a dip of $75^{\circ}-80^{\circ} \mathrm{NW}$. This vein can be traced 135 feet northeastward from the larger vein. It is $0.7-1.0$ foot thick and is brown to black in color. The predominant gangue mineral in this vein, unlike the northwest-trending vein, is pink to tan microcline. Quartz, however, is also common. The color of the vein is due to limonite and a black manganese oxide mineral. Other minerals identified are thorite, brockite, apatite, magnetite, specularite, and calcite. Four samples taken across this vein (pl. $2 G$; table 15 ) contained $0.38-1.70$ percent $\mathrm{ThO}_{2}$.

\section{LAST CHANCE}

The Last Chance property (loc. 82), which is on one of the longer veins in the Lemhi Pass district, lies just east of the Continental Divide in sec. 29, T. 10 S., R. 15 W., Montana principal meridian. The northwesternmost exposures of this vein are on the south side of North Frying Pan Creek, and it can be traced from there southeastward over the divide and across South Frying Pan Creek. Several roads reach various parts of this vein, but from Lemhi Pass there are two principal routes: (1) Drive 2.4 miles eastward on the road that crosses the pass, then southward on a dirt road along the north side of Frying Pan and South Frying Pan Creeks for 4.8 miles to the property; (2) drive south from Lemhi Pass along the Continental Divide for 2.0 miles, then turn southeast off the divide and follow another road for 1.3 miles across North Frying Pan Creek to this road's intersection with the first route. This junction is 1.2 miles from the property. The Last Chance vein is principally on the Last Chance, Shady Tree, and Last Chance 30 claims. The first discovery was made on the Last Chance, which was located by R. A., Ned, Billy, and Dave Wellborn, on July 15, 1949. In 1950 the property was optioned to the Elkhorn Mining Co. who, using a U.S. Defense Minerals Exploration Administration loan, exposed the vein in several places by means of bulldozer trenches and cut the vein 240 and 290 feet below the surface in two diamond-drill holes. The Elkhorn Mining Co. allowed their option to lapse, and the Wellborns later sold this property to the Sawyer Petroleum Co. In the mid-1960's Sawyer Petroleum Co. went into a partnership with Union Pacific Railroad Co. who did the assessment work. By 1970 Union Pacific Railroad Co. was no longer involved in this property. Sawyer Petroleum Co., whose name was changed to Sawyer-Adecor International, Inc., did the assessment work on this property in October 1973.

On the surface the vein has been exposed by many bulldozer trenches (pl. 2D), including several large longitudinal cuts that completely expose the vein for $900 \mathrm{feet}$ at its northwest end. The vein also has been explored by two adits and a shaft. The west adit consists of a crosscut $630 \mathrm{feet}$ long that intersects the vein 500 feet from the portal. From this intersection a drift 35 feet long extends to the west, and one 220 feet long extends to the southeast. The vein, where it is cut by the crosscut, is about 160 feet below the surface. The east adit consists of a 452-foot slightly curved drift to the northwest that follows the vein for 355 feet. Between these two adits is an 80-foot-deep vertical shaft, sunk along the footwall of the vein. A short crosscut driven west from the bottom of the shaft is about 22 feet long and cuts the vein, which is here 14 feet thick (Geach, 1966, p. 15). In addition, Union Pacific Railroad Co. drilled several diamond-drill holes.

One main vein, which intrudes gray fine-grained micaceous quartzite of Precambrian Y age, is found on this property. This vein has an overall strike of about N. $55^{\circ} \mathrm{W}$., but as it follows a somewhat irregular fracture zone, it varies from about $\mathrm{N} .40^{\circ}-80^{\circ} \mathrm{W}$. in different parts of the vein. Its dip also varies from about $40^{\circ}-70^{\circ} \mathrm{SW}$. The vein has a known length of 4,350 feet (pl. 2D). A short distance northwest of the last exposure, the vein has been reported to end against a fault. Southeast of the last known exposure, thick cover on a heavily wooded slope makes the vein 
difficult to trace. The vein thickens and thins along strike and measured thicknesses range from 5 to 40 feet. In the east adit the vein varies from 8 to 13 feet thick, and in the crosscut of the west adit the vein is 30 feet thick.

The Last Chance vein is exposed on the surface on the east side of the ridge that separates South from North Frying Pan Creeks. These exposures are quartz rich; those parts of the vein that are rich in iron oxides are more easily weathered and are not exposed. The vein varies from white containing black streaks to deep brown. Quartz is the principal gangue mineral, although in some places yellow-stained pale-pink microcline is a common mineral. White platy barite, although not abundant, is found in most samples. Specularite is the most abundant iron oxide. In some places red granular hematite also occurs. Dark-brown goethite is also abundant and commonly colors the entire rock. Magnetite is found in most places, but is sparse. The iron oxides commonly vein the earlier formed minerals. Goethite may occur as a pseudomorphous replacement of pyrite cubes. Dark-reddish-brown shiny thorite is the most abundant thorium mineral, although yellow-brown monazite is found in minor amounts in most samples. Brockite was noted in one sample. Minor amounts of many minerals were found in this vein. The most common of these were pyrite, rutile, and black manganese oxide minerals. Other minerals noted in scant amounts in a few samples are: calcite, muscovite, biotite, apatite, malachite, jarosite, and anatase.

The analytical results of 17 samples taken by us (pl. 2D) from the surface workings and in the west and east adits are given in table 16 . They contained $0.017-1.45$ percent $\mathrm{ThO}_{2}$.

TABLE 16.-Analyses of samples from the Last Chance vein, Mont. [C, chip sample; Ch, channel sample; n.d., no data]

\begin{tabular}{|c|c|c|c|c|}
\hline $\begin{array}{l}\text { Sample No. } \\
\text { (MHS-) }\end{array}$ & Location & $\begin{array}{l}\text { Sample length } \\
\text { and type } \\
\text { (ft) }\end{array}$ & $\begin{array}{c}{ }^{\text {'ThO }} \\
\text { (percent) }\end{array}$ & $\begin{array}{l}{ }^{2} \text { Total rare- } \\
\text { earth oxides } \\
\text { (percent) }\end{array}$ \\
\hline $12-74$ & Surface, west end......... & $10 \mathrm{C}$ & 0.74 & N.d. \\
\hline $13-74$ & .......do............. & $7.0 \mathrm{C}$ & .34 & n.d. \\
\hline $11-74$ & $\begin{array}{l}\text { Surface, } 120 \mathrm{ft} \text {. } \\
\text { west of ridge crest. }\end{array}$ & $6.6 \mathrm{C}$ & .25 & n.d. \\
\hline $63-69$ & Surface at ridge crest.... & $6.8 \mathrm{C}$ & .54 & n.d. \\
\hline $155-67$ & $\begin{array}{l}\text { Surface cut, } 150 \mathrm{ft} \text {. } \\
\text { NW of shaft. }\end{array}$ & $2.2 \mathrm{Ch}$ & .30 & 0.94 \\
\hline $156-67$ & .......do.............. & $3.2 \mathrm{Ch}$ & .43 & 2.04 \\
\hline $157-67$ & .......do............. & $5.7 \mathrm{Ch}$ & .61 & 1.00 \\
\hline $158-67$ & .......do............ & $5.2 \mathrm{Ch}$ & .15 & 1.38 \\
\hline $159-67$ & .......do............ & $2.0 \mathrm{Ch}$ & .017 & n.d. \\
\hline $15-74$ & $\begin{array}{l}\text { Surface, } 150 \mathrm{ft} . \\
\text { SE of shaft. }\end{array}$ & $12 \mathrm{C}$ & .43 & n.d. \\
\hline $81-73$ & $\begin{array}{l}\text { Surface, near SE end } \\
\text { of vein. }\end{array}$ & $6.0 \mathrm{C}$ & .038 & n.d. \\
\hline $149-68$ & West adit ...... & $12.5 \mathrm{C}$ & .36 & .20 \\
\hline $150-68$ & .......do............ & $10.0 \mathrm{C}$ & .26 & .18 \\
\hline $148-68$ & .......do................. & $6.9 \mathrm{C}$ & 1.45 & 1.34 \\
\hline $151-68$ & East adit ........ & $10.0 \mathrm{C}$ & .16 & .19 \\
\hline $152-68$ & .......do............. & $14.0 \mathrm{C}$ & .20 & .28 \\
\hline $153-68$ & .......do............. & $14.8 \mathrm{C}$ & .074 & n.d. \\
\hline
\end{tabular}

'Gamma-ray spectrometric analysis by C. M. Bunker and C. A. Bush, U.S. Geological Survey Denver, Colo.

${ }^{2}$ X-ray fluorescence spectrographic analysis by J.S. Wahlberg and V. S. Shaw, U.S. Geological Survey, Denver, Colo.
The vein varies in $\mathrm{ThO}_{2}$ content in different parts, and the southeastern end is noticeably leaner than the northwestern end. The southeasternmost sample, plus three samples taken from the east adit, ranged from 0.038 to 0.20 percent $\mathrm{ThO}_{2}$; the three samples from the west adit, on the other hand, contained $0.26-1.45$ percent $\mathrm{ThO}_{2}$. In addition, 16 other surface samples have been reported on by Sharp and Cavender 1962, p. 62-63). These samples, which were collected along the vein from the divide between North and South Frying Pan Creeks for 950 feet to the east, ranged from 0.05 to 2.1 percent $\mathrm{ThO}_{2}$. The rare-earth oxide content of this vein appears to be somewhat greater than the $\mathrm{ThO}_{2}$ content. The total rare-earth oxide content of nine of the samples ranged from 0.18 to 2.04 percent. The amounts of the individual rare earths in these samples have been previously published (Staatz and others, 1972, p. 76-77). Neodymium is the principal rare earth, and europium occurs in above-average amounts.

\section{DAN PATCH}

The Dan Patch (loc. 98) is on the top of a ridge 1.5 miles east of Bear Creek and between that creek and Bear Gulch. This property, which is near the eastern edge of the district, lies southwest of the Dan Patch fault (pl. 1). The property may be reached by steep secondary roads from either the east or the west. Two veins are exposed in the workings of the Dan Patch 1 and 2, which were located on July 1, 1956, by R. A., Ned, Grace, and Hattie Wellborn, and Edward McCande. Assessment work on these claims was done in July 1974 by Ned Wellborn. The two veins on these two claims were developed by 15 bulldozer trenches and four smaller trenches dug within the larger bulldozer trenches (fig. 26). The veins were intruded into a Precambrian $Y$ gray fine-grained micaceous quartzite. The larger, or northern, vein has a general strike of N. $75^{\circ} \mathrm{W}$., and dips $55^{\circ}-75^{\circ} \mathrm{SW}$. This vein ranges in thickness from 2 to 2.5 feet. It can be traced across nine bulldozer trenches for 508 feet. A possible continuation of this vein, although not exactly on line with its extension, is found in a trench 420 feet to the northwest. To the southeast, extension of this vein is limited by basalt, which is exposed some 50 feet from the last trench exposure, and by the Dan Patch fault. The smaller vein, to the south, has been exposed only in two trenches (fig. 26). The strike of this vein changes, being $\mathrm{N} .77^{\circ} \mathrm{W}$. in the northwestern of the two trenches and N. $40^{\circ} \mathrm{W}$. in the other trench. Dip is from about $75^{\circ} \mathrm{SW}$ to vertical. This vein is exposed for only 105 feet and is $0.5-6$ feet thick.

Both veins consist principally of quartz, some pink microcline, and goethite, which colors the veins brown. Other iron oxides are hematite and magnetite. Hematite occurs chiefly as black shiny plates of specularite, although some dark-red granular material was found. Magnetite is a very minor constituent. Dark red shiny thorite was the only thorium mineral noted. Other minerals include a little white 
platy barite and minor shiny dark-brown rutile.

Three samples taken from the north vein yielded $0.36-0.71$ percent $\mathrm{ThO}_{2}$ (fig. 26; table 17). One of these samples (MHS-126-68) was also analyzed for total rare-earth oxides; it contained 0.083 percent.

Three samples from the smaller south vein yielded 0.22 to 0.47 percent $\mathrm{ThO}_{2}$. One of these samples (MHS-127-68) was also analyzed for total rare-earth oxides, and it contained 0.22 percent.

\section{REACTOR}

The Reactor property (loc. 107) lies on a steep subsidiary ridge on the east side of Bear Creek (pl. 1) near its headwaters. It is in the eastern part of the district approximately 1.5 miles southwest of the Dan Patch property. The eastern edge of this property is reached by a four-wheel-drive vehicle road along a broad ridge that trends northward from the Continental Divide and that, at the Reactor property, separates Bear Creek from the North
Fork of Everson Creek. The Reactor property consists of the Reactor Nos. 1 to 6 claims and was located by Carroll Wells and Miley Evans on September 15, 1959. This property subsequently became part of the $\mathrm{ThO}_{2}$ and Rare Metals Exploration, Inc., portfolio. The president of this company is Carroll Wells, and assessment work was done by him on this property in September 1973. Development work consists of a dozen trenches down a steep rocky ridge ( $\mathrm{pl} .2 F$ ) and several long trenches on the covered slope to the northeast. The difference in elevation between the uppermost and lowermost trenches is approximately 700 feet. The country rock is the Precambrian Y gray fine-grained micaceous quartzite, which in places is banded and has thin interbeds of siltite.

Veins on the Reactor property follow a steeply-dipping northwest-trending shear zone. This zone is well exposed in trenches in the southeast part of the property, and is here approximately 50 feet wide. The largest vein is exposed in the easternmost working and can be traced for 1,300 feet to the

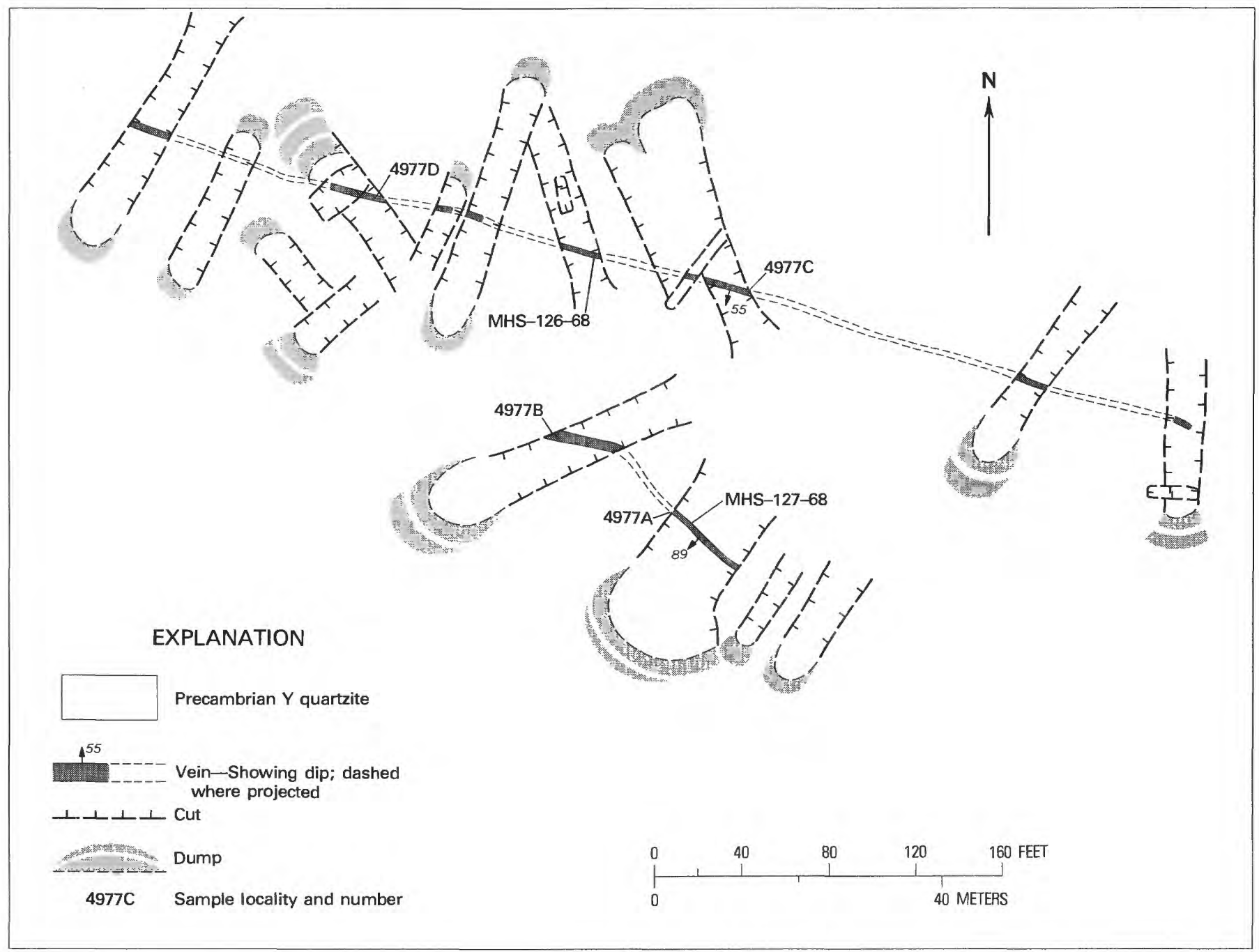

FIGURE 26.--Geologic map of the Dan Patch property (loc. 98). Mapped by B. J. Sharp and D. L. Hetland, 1965; revised by M. H. Staat7., 1974. 
TABLE 17.-Analyses of samples from the Dan Patch property, Mont. [C, chip sample; G, grab sample; n.d.. no data; NA, not applicable]

\begin{tabular}{|c|c|c|c|c|c|}
\hline Vein & $\begin{array}{c}\text { Sample } \\
\text { No. }\end{array}$ & $\begin{array}{r}\text { Sample } \\
\text { and } \\
\text { (f }\end{array}$ & $\begin{array}{l}\text { length } \\
\text { type } \\
\text { t) }\end{array}$ & $\begin{array}{c}\mathrm{ThO}_{2} \\
\text { (percent) }\end{array}$ & $\begin{array}{l}\text { Total rare- } \\
\text { earth oxides } \\
\text { (percent) }\end{array}$ \\
\hline North vein & $\begin{array}{l}\text { 4977D } \\
\text { MHS-126-68 } \\
4977 C\end{array}$ & $\begin{array}{l}2.0 \\
\text { NA } \\
2.5\end{array}$ & $\begin{array}{l}\mathrm{C} \\
\mathrm{G} \\
\mathrm{C}\end{array}$ & $\begin{array}{r}10.71 \\
2.41 \\
1.36\end{array}$ & $\begin{array}{l}\text { N.d. } \\
30.083 \\
\text { n.d. }\end{array}$ \\
\hline South vein & $\begin{array}{l}\text { 4977B } \\
4977 \mathrm{~A} \\
\text { MHS-127-68 }\end{array}$ & $\begin{array}{l}6.0 \\
3.0 \\
1.0\end{array}$ & $\begin{array}{l}\mathrm{C} \\
\mathrm{C} \\
\mathrm{C}\end{array}$ & $\begin{array}{l}1.26 \\
.22 \\
2.47\end{array}$ & $\begin{array}{l}\text { n.d. } \\
\text { n.d. } \\
3.22\end{array}$ \\
\hline
\end{tabular}

'Wet chemical analysis by Lucius Pitkin, Inc., Grand Junction, Colo.

Wet chemical analysis by Lucius Pitkin, Inc.. Grand Junction, Colo.
zGamma-ray spectrometric analysis by C. M. Bunker and C. A. Bush. U.S. Geological Survey Denver. Colo.

"X-ray fluorescence spectrographic analysis by J, S. Wahlberg and V. S. Shaw. U.S. Geological Survey, Denver, Colo.

northwest (pl. $2 F)$. This vein ranges in thickness from 0.8-5.0 feet. It has an overall strike of N. $38^{\circ} \mathrm{W}$., but ranges from about N. $28^{\circ} \mathrm{W}$. to N. $48^{\circ} \mathrm{W}$. Dip varies from about $70^{\circ}$ to $85^{\circ} \mathrm{SW}$. Some $15-20$ feet south of this vein and more or less parallel to it is a smaller vein some 4-6 inches thick. This vein is only exposed in three trenches, and if continuous, would be at least 656 feet long. The long vein dies out to the northwest, but two other veins are found in this area. A northwest vein having a N. $23^{\circ} \mathrm{W}$. trend is exposed in four places. This vein, which dips about $45^{\circ} \mathrm{SW}$., can be traced for 290 feet. It is 1-3.5 feet thick. The other vein lies southwest of the northwest vein, and is exposed in the two lowest (westernmost) trenches on the ridge (pl. $2 F$ ). This vein strikes $\mathrm{N} .63^{\circ} \mathrm{W}$. and dips about $55^{\circ} \mathrm{SW}$. It has been traced for 74 feet, and is $1-3$ feet thick.

These veins are cherry red to yellow brown in color and their principal gangue mineral is pale-pink microcline. White quartz is also moderately abundant. Hematite is by far the most abundant iron oxide mineral. It generally occurs as small black shiny plates of specularite, although in places it occurs as red granular hematite. Dark-brown limonite is fairly common, and black magnetite is rare. Reddish-orange thorite was the only thorium mineral identified. In addition, a little pyrite and clear plates of barite occur in some places.

Three of the four veins were sampled. Seven samples were taken along the long east vein. They contained from 0.007 to 1.32 percent $\mathrm{ThO}_{2}$ (pl. $2 F$; table 18). A sample from near the center of the northwest vein yielded 1.79 percent $\mathrm{ThO}_{2}$, and one from the short southwest vein had 0.69 percent $\mathrm{ThO}_{2}$.

TABLE 18. - Analyses of chip samples from the Reactor property, Mont.

\begin{tabular}{|c|c|c|c|}
\hline Vein & $\begin{array}{l}\text { Sample } \\
\text { No. }\end{array}$ & $\begin{array}{l}\text { Sample length } \\
\text { (ft) }\end{array}$ & $\begin{array}{c}\mathrm{ThO}_{2} \\
\text { (percent) }\end{array}$ \\
\hline \multirow{7}{*}{ Northeast vein. } & MHS-25-69 & 1.0 & 10.15 \\
\hline & $4974 \mathrm{~B}$ & 2.0 & 21.23 \\
\hline & $4974 \mathrm{C}$ & 2.0 & 2.14 \\
\hline & $4974 \mathrm{~A}$ & 2.0 & 21.10 \\
\hline & M HS-26-69 & 1.3 & 11.32 \\
\hline & MHS-2-74 & 1.5 & 1.007 \\
\hline & $4974 \mathrm{D}$ & 5.0 & 2.07 \\
\hline Northwest vein. & $4974 \mathrm{~F}$ & 3.5 & 21.79 \\
\hline Southwest vein. & $4974 \mathrm{E}$ & 3.0 & 2.69 \\
\hline
\end{tabular}

'Gamma-ray spectrometric analyses by C. M. Bunker and C. A. Bush, U.S. Geological Survey ${ }^{2}$ Wet chemical analyses by Lucius Pitkin, Inc., Grand Junction, Colo.
Only the narrow vein south of the long east vein was not sampled. This vein is five times less radioactive than the larger vein it parallels.

\section{ELKHORN}

The Elkhorn (loc. 108) is on the northwest side of the prominent ridge that separates Reese Creek from Yearian Creek in the NW1/4NE1/4 sec. 28 , T. 18 N., R. 25 E., Boise meridian, Idaho. It is about 0.5 mile northeast of the $\mathrm{ThO}_{2}$ property and is reached from the road that passes the $\mathrm{ThO}_{2}$ and connects the Lemhi Valley with the Continental Divide. This property is on the Elkhorn No. 1 and No. 2 claims, which were located by Carroll Wells and Ross Murray on July 6, 1960. It was owned in July 1973 by Ross Murray. Development work consists of six bulldozer trenches, 60-155 feet long (fig. 27). The country rock is a Precambrian Y gray micaceous quartzite that strikes $\mathrm{N} .12^{\circ} \mathrm{E}$. and dips $35^{\circ}-45^{\circ}$ SE.

A curved vein is exposed in the workings, which near the center of the area of figure 27 has a strike of N. $28^{\circ} \mathrm{W}$., but in the southeasternmost part has a strike of N. $55^{\circ}$ W. Dip appears to be nearly vertical. The vein has been traced for 630 feet. In the next to the southeasternmost trench the vein has split into four veinlets, and in the southeasternmost trench only a soil anomaly was noted. Thus the vein appears to be pinching out in this direction. In the northwesternmost trench a soil anomaly was also noted but this downhill locality is heavily forested and the overburden is thick. Hence, the soil anomaly may represent the top of a vein under a thick cover of overburden, or radioactive debris carried downhill from the vein. The vein ranges in thickness from 0.5 inch near the southeast end to 1.5 feet near the center. Most of it appears to be between 0.5 and $0.7 \mathrm{foot}$ thick. The vein is limonitic brown and has some black streaks. It consists principally of granular limonite-stained microcline, although in places quartz is also common. Dark-brown granular goethite is the most abundant iron oxide mineral. Some black shiny plates of specularite and minor black magnetite are the other iron oxides. Thorite was the only thorium mineral noted, and in the trenches near the center of the area of figure 27 it is abundant enough to be observed in hand specimens. Minor amounts of muscovite, biotite, rutile, and apatite are also present. Two samples were taken from the central part of this vein (fig. 27). One (651) contained 1.63 percent $\mathrm{ThO}_{2}$; the other (MHS-82-69) yielded 4.16 percent $\mathrm{ThO}_{2}$.

\section{APEX}

The Apex vein (loc. 136) is on a high ridge on the west side of Flume Creek in the NW1/4 NW $1 / 4$ sec. 4 , T. 19 N., R. 25 E. The vein lies about 1 mile north-northeast of the Lemhi Pass fault and is one of the few known veins north of this fault. This property is at the north end of the district (pl. 1) in the 


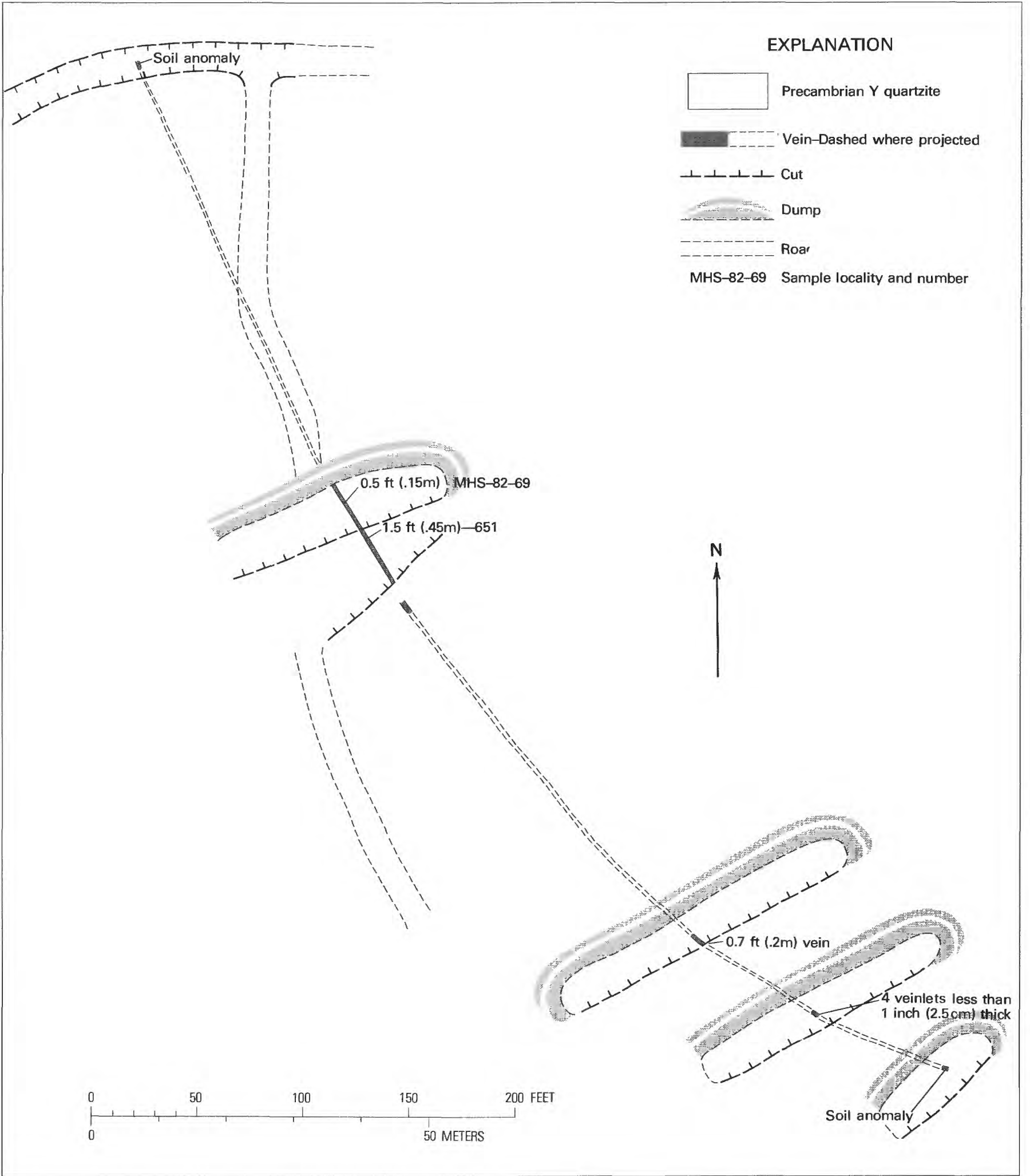

Figure 27.-Geologic map of the Elkh̆orn property (loc. 108). Mapped by B. J. Sharp and D. L. Hetland, 1965; revised by M. H. Staatz, 1973. 


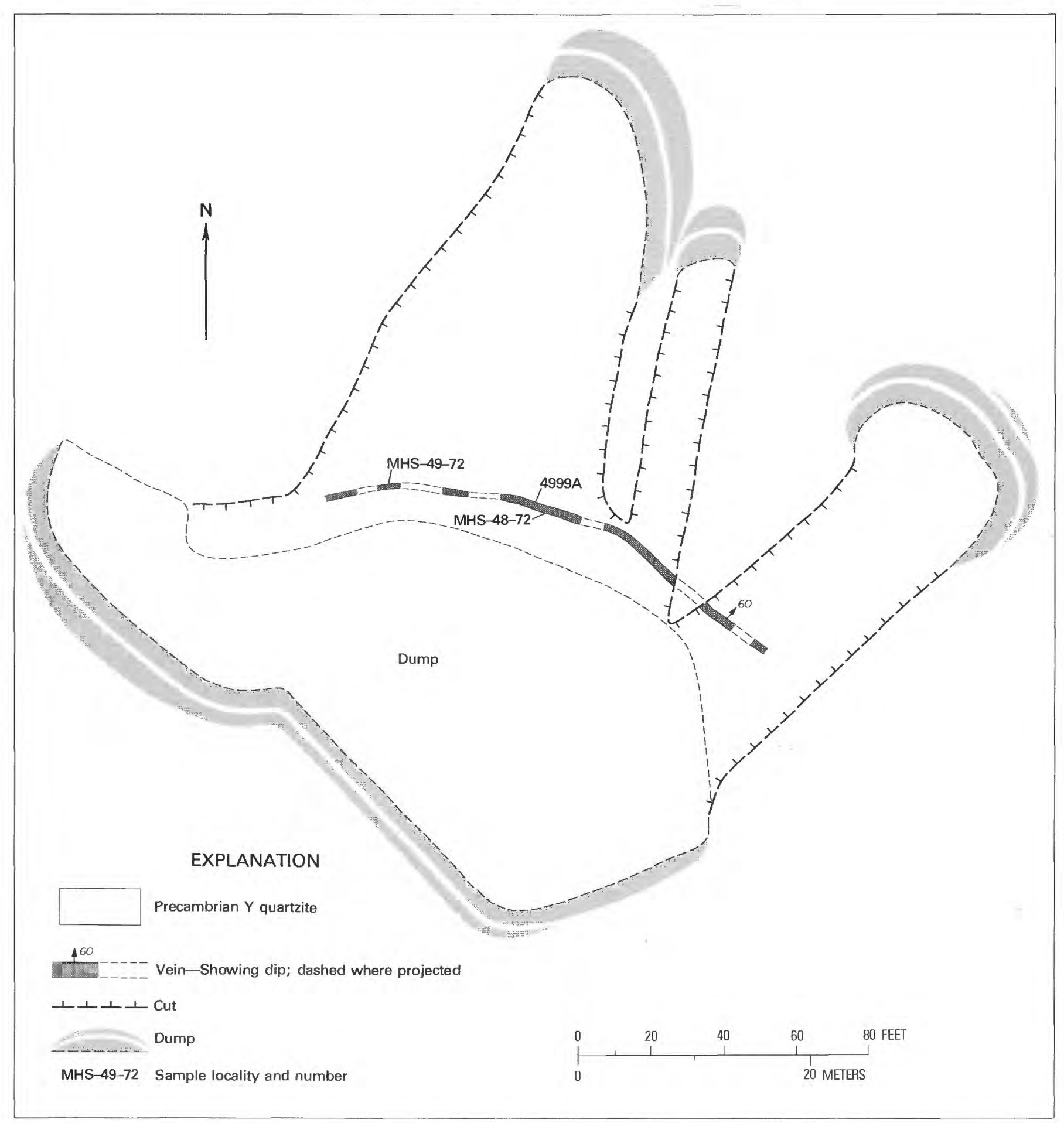

FIGURE 28. - Geologic map of the Apex vein (loc. 136). Mapped by B. J. Sharp and D. L. Hetland, 1965; revised by M. H. Staat7. 1973.

Salmon National Forest, and is reached by about 2 miles of steep secondary road from the headwaters of Poison Creek. This property has been controlled in the past by the Lemhi Pass Thorium Corp. Workings on the property consist of at least three interconnected trenches covering an area of 275 by 240 feet (fig. 28). Bedrock consists of dark gray fine-grained quartzite of Precambrian Y age.

The workings expose a curved vein having a general strike 
TABLE 19.-Analyses of samples from the Apex property, Idaho

[C. chip sample; G. grab sample; N.d., no data; NA, not applicable; <. Less than]

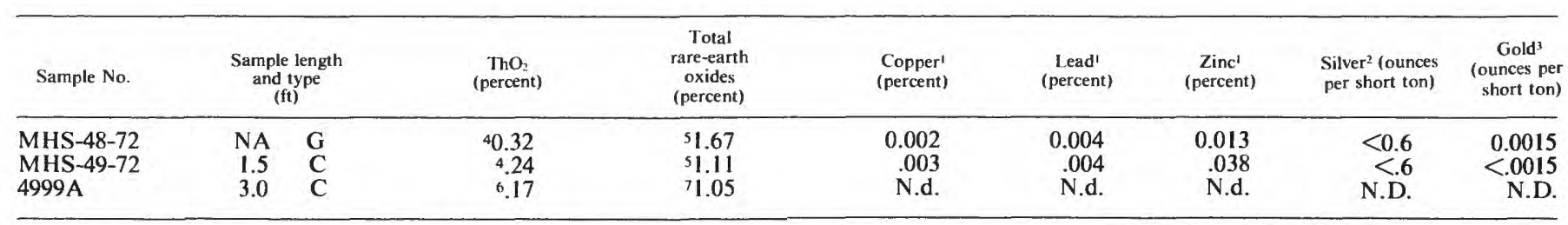

'Atomic-absorption analysis by J. A. Thomas, U.S. Geological Survey, Denver, Colo.

Thomas and W. D. Goss, U.S. Geological Survey, Denver,

'Fire assay and atomic-absorption analysis by W. D. Goss, A. W. Haubert, and J. A. Thomas, U.S. Geological Survey,

Denver, Colo.

"Gamma-ray spectrometric analysis by C. M. Bunker and C. A. Bush, U.S. Geological Survey, Denver, Colo.

Quantitative spectrographic analysis by N. M. Conklin, U.S. Geological Survey, Denver, Colo.

tWet chemical analysis by Lucius Pitkin, Inc., Grand Junction, Colo.

'X-ray florescence spectrographic analysis by the U.S. Bureau of Mines. Salt Lake City. Utah.

of $\mathrm{N} .75^{\circ} \mathrm{W}$. and dipping $55^{\circ}-60^{\circ} \mathrm{NE}$. It has an exposed length of $135 \mathrm{feet}$ and ranges in thickness from 1.5 to 3.0 feet. Much of the vein is dark brown due to limonite staining but in some places it has dark-purple spots due to fluorite. This is the only vein in the district in which fluorite is readily visible in hand specimens and the only one that has more than a fraction of a percent of this mineral. Distribution of the fluorite is erratic, as it may be a major gangue mineral at one place and absent in another place. The principal gangue mineral throughout the vein is quartz. Other gangue minerals include small amounts of pink microcline and tan calcite. Iron oxides are common, especially specularite, but the vein also has limonite and magnetite. The rare-earth and thorium minerals are shiny yellowish-orange synchisite, $\mathrm{CeFCO}_{3} \cdot \mathrm{CaCO}_{3}$, and red porcelaneous thorite. Synchisite is by far the most common. The small amount of thorite identified in the analyzed samples is not nearly enough to account for their thorium content, and much of the rest may be in synchisite, where thorium may proxy for the rare earths. Minor amounts of barite, rutile, an unidentified manganese oxide mineral, and apatite are also present. Three samples were taken from this vein. They contained 0.17-0.32 percent $\mathrm{ThO}_{2}$ (fig. 28; table 19). As might be expected, their total rare-earth oxide content was high and ranged from 1.05 to 1.67 percent. Two of the samples were also analyzed for base and precious metals. They contained only minor amounts of base metals, silver was not detected, and gold was found in only one sample in a barely detectable amount (table 19).

\section{LONE STAR NO. 2}

This claim (loc. 145) is on the nose of a small ridge on the southeast side of Pattee Creek just south of the mouth of Poison Creek in the SE $1 / 4$ SE $1 / 4$ sec. 11 , T. 19 N., R. 24 E., Boise meridian, Idaho. It lies just above the creek bottom and is reached by the road up Pattee Creek. The property was originally located by J. A. Rucker. It has had several owners, being controlled by Idaho Thorium Co. in 1957 (Anderson, 1958, p. 58), Nuclear Fuels and Rare Metals Corp. in 1965, and Joyce Corp. in 1970. Workings consist of a principal cut approximately 200 feet long about 30 feet above the valley bottom, and several branching and interconnected roads on the steep slope above (fig. 29). Workings are cut in a Precambiran $\mathrm{Y}$ gray to greenish-gray banded fine-grained micaceous quartzite that strikes N. $50^{\circ}$ E. and dips $15^{\circ} \mathrm{SE}$.

Two veins are exposed on this property. The northernmost one is exposed in the principal cut. It strikes N. $75^{\circ} \mathrm{W}$. and dips $45^{\circ}-65^{\circ} \mathrm{SW}$. This vein can be traced for 268 feet between cuts and is 1.5-3.0 feet thick. In the main cut near its west end it is offset about 7 feet by a shallowly dipping fault that strikes N. $30^{\circ}$ E. and dips $15^{\circ} \mathrm{SE}$. This vein is mainly black, and consists principally of white quartz and of pink microcline impregnated with black shiny specularite. Red porcelaneous thorite was the only thorium mineral noted. A little brown limonite, yellow resinous rutile, black biotite, white barite, and white apatite are also present. Five samples were analyzed for $\mathrm{ThO}_{2}$ from this vein, and they contained 0.41-1.75 percent (fig. 29; table 20).

About 200 feet south of this vein in the principal cut another vein is exposed. The second vein has two parts: a narrow (0.7-1.5-foot-thick) iron oxide-rich hanging wall and a thick (9-30-foot-thick) quartz-rich footwall containing hematite. The iron-rich part is only exposed in the main cut and on the road above the cut. The quartz-rich part not only is exposed in the cuts, but in places forms prominent outcrops on the hillside. The strike of this vein ranges from N. $75^{\circ}$ W. near its western end to N. $75^{\circ}$ E. and it dips $75^{\circ}-80^{\circ} \mathrm{N}$. The thick footwall part of the vein is similar in appearance and thickness to a quartz-hematite vein on the Silver Queen 52B property, less than 0.5 mile east. As the two are on strike with one another and as there are several scattered outcrops of similar vein material in between, it is probable that this is one long continuous vein more than 0.5 mile long. On the Lone Star No. 2 property the vein has been traced for 555 feet (fig. 29), and is 10-31.5 feet thick. It is thickest in the cut at its southwesternmost exposure and thins to the northeast. The footwall part of the vein varies in color from light gray to dark purplish gray and consists mainly of quartz intermixed with specularite. Radioactivity here is highly variable, much of the vein containing little in the way of thorium minerals. An 8.0-foot sample from this part of the vein contained only 0.004 percent $\mathrm{ThO}_{2}$. Thorite 


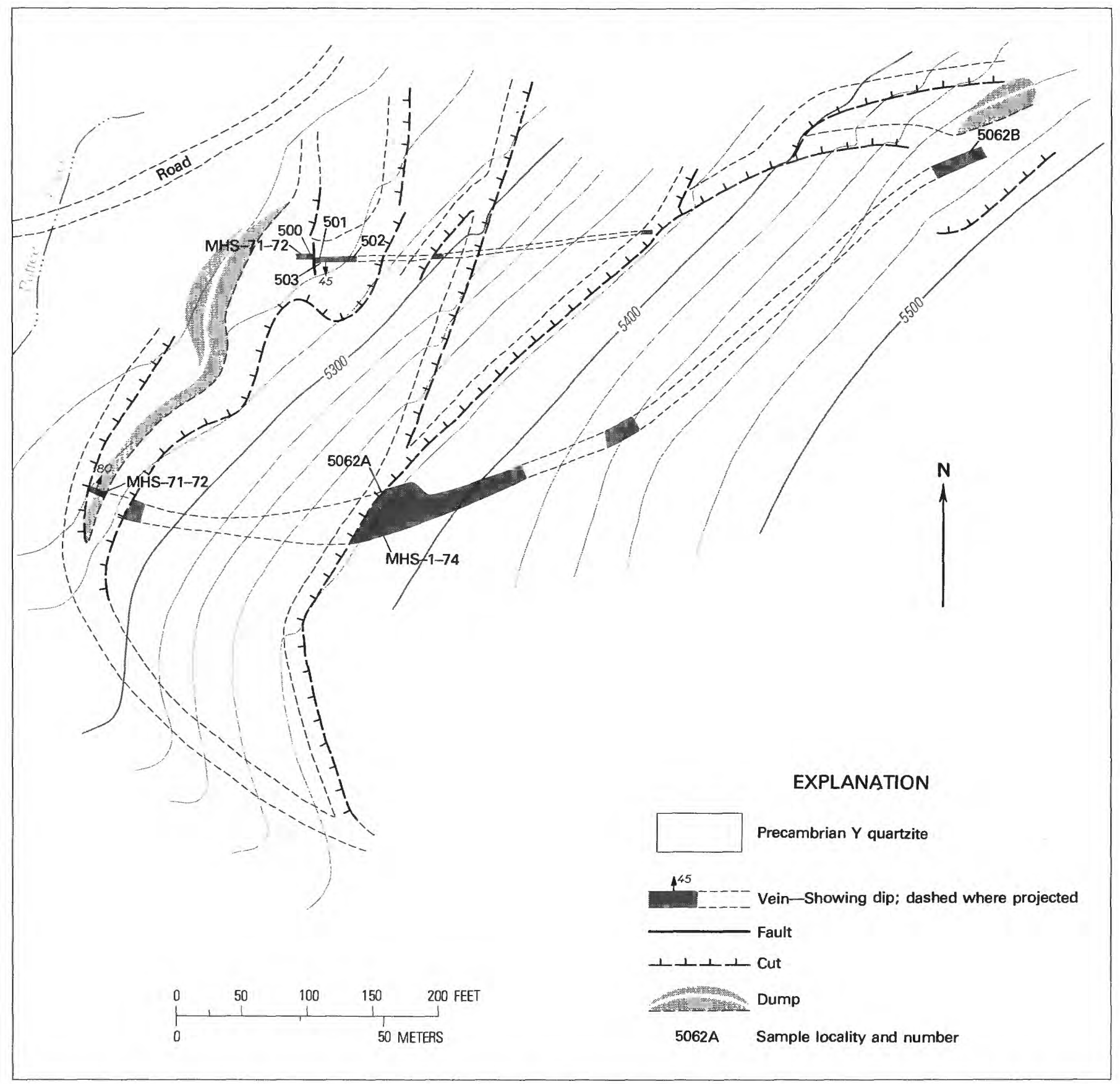

Figure 29.-Geologic map of the Lone Star No. 2 property (loc. 145). Mapped by B. J. Sharp and D. L. Hetland, 1965; revised by M. H. Staatz, 1973.

is most commonly found concentrated in the hanging-wall part of this vein. Three samples from this part of the vein yielded 0.32-1.75 percent $\mathrm{ThO}_{2}$ (fig. 29; table 20).

The chief gangue mineral of the dark-brown hanging-wall part of the vein is quartz, but it also contains abundant microcline and black shiny specularite. In addition, some of the feldspar is coated with limonite, and a small amount of magnetite is present. Red porcelaneous thorite is the principal thorium mineral. Barite was the only other mineral noted.

\section{SILVER QUEEN 52B}

This property (loc. 146) lies across a small gulch about 250 feet above the valley bottom in the $\mathrm{S} 1 / 2 \mathrm{sec} .12, \mathrm{~T}$. 19. N., R. 24 E., Boise meridian, Idaho. It is about 0.5 mile up the valley from its mouth on Pattee Creek, and it is reached by the road up Pattee Creek. The Silver Queen 52B was located in 1955 by J. A. Rucker. This property was owned in 1957 by the Idaho Thorium Co. (Anderson, 1958, p. 50), in 1965 by the Nuclear Fuels and Rare Metals Corp. and in 1970 by the 
TABLE 20.-Thorium analyses of chip samples from the Lone Star No. 2 property, Idaho

\begin{tabular}{|c|c|c|c|}
\hline Vein & $\begin{array}{c}\text { Sample } \\
\text { no. }\end{array}$ & $\begin{array}{l}\text { Sample length } \\
\text { (ft) }\end{array}$ & $\begin{array}{c}\mathrm{ThO}_{2} \\
\text { (percent) }\end{array}$ \\
\hline \multirow[t]{5}{*}{ North } & 503 & 1.5 & 10.52 \\
\hline & 500 & 3.0 & 1.45 \\
\hline & MHS-71-72 & 1.5 & 2.41 \\
\hline & 501 & 2.0 & 1.50 \\
\hline & 502 & 2.0 & 11.75 \\
\hline \multirow[t]{4}{*}{ South } & MHS-70-72 & .7 & 2.39 \\
\hline & $5062 \mathrm{~A}$ & 2.5 & 1.32 \\
\hline & $5062 \mathrm{~B}$ & 2.0 & 11.75 \\
\hline & MHS-1-74 & 8.0 & 2.004 \\
\hline
\end{tabular}

IWet chemical analysis by Lucius Pitkin, Inc., Grand Junction, Colo.

${ }^{2}$ Gamma-ray spectrometric analysis by C. M. Bunker and C. A. Bush, U.S. Geological Survey. Denver, Colo.

Joyce Corp. On the west side of the small gulch, workings consist of one large cut 640 feet long having a back as much as 55 feet high, and several interconnected roads, and on the east side of the gulch by three levels of roads (pl. $2 B$ ). Bedrock on this property is gray to greenish-gray fine-grained feldspathic quartzite and minor interbedded greenish-gray siltite of Precambrian Y age.

Four veins are exposed in and adjacent to the main cut. The northernmost vein is a massive quartz-hematite vein of erratic but generally low thorium content. This vein probably extends westward for 0.5 mile to the Lone Star No. 2 property. The other three are calcite-rich veins. The big cut was excavated mainly to expose the southern or largest of these three veins. The other two calcite-rich veins are only exposed in the central part of the floor of the main cut. A small northwest-trending fault down the small gulch east of the main cut offsets the quartz-hematite vein and largest calcite-rich vein about 140 feet to the northwest (pl. 2B). The largest calcite-hematite vein (southernmost vein) strikes $\mathrm{N}$. $80^{\circ} \mathrm{W}$. and $\operatorname{dips} 34^{\circ}-55^{\circ} \mathrm{SW}$. It has been traced for 750 feet and ranges in thickness from 0.6 to 3.0 feet. This vein varies in color from brown to black and consists principally of limonite-stained calcite and lesser amounts of quartz and microcline. East of the gulch, microcline becomes the most abundant gangue mineral. Goethite is the chief iron oxide in most places. This mineral occurs not only in veinlets but also forms dark-brown cubes and pyritohedrons-a pseudomorphous replacement of pyrite. Black shiny specularite is common and east of the gulch is more abundant than limonite. All samples contain minor amounts of magnetite, some of which is included in specularite. Part of the coloration is due to a black manganese oxide mineral. Brick-red thorite was the only thorium mineral noted. In addition, minor amounts of rutile, barite, apatite, jarosite, muscovite, fluorite, pyrite, and chalcopyrite were identified in some samples. The vein is highly brecciated and has at least two generations of minerals; the second set of minerals follows a set of fractures in early minerals and is in turn fractured. Eleven samples were taken from this vein, and they range from 0.12 to 2.91 percent $\mathrm{ThO}_{2}$ (pl. $2 \mathrm{~B}$; table 21).
Two of these samples (MHS-65-72 and MHS-67-72) were also analyzed for base and precious metals; only minor amounts of lead, zinc, and copper, and negligible amounts of gold and silver were detected (table 21).

Approximately 15 feet north of the southern vein lies the south-central vein. This vein is parallel to the southern vein, striking N. $80^{\circ} \mathrm{W}$. and dipping $55^{\circ} \mathrm{SW}$. It is exposed only in the bottom of the main cut for a distance of 125 feet. Its thickness ranges from 0.7 to 2.0 feet. This vein is black and consists principally of limonite-stained calcite. Other common gangue minerals are white quartz and pink feldspar. The vein is colored by black shiny specularite and black manganese oxides. Limonite commonly occurs as dark-brown pyritohedrons, a pseudomorphous replacement of pyrite. Magnetite occurs but is generally included in the specularite. Red shiny thorite, the only thorium mineral noted, is common. Minor amounts of orange to tan striated rutile, white frosted apatite, brassy pyrite, and chalcopyrite were the other minerals identified. Three samples taken from this vein yielded $0.79-1.07$ percent $\mathrm{ThO}_{2}$ (pl. $2 \mathrm{~B}$ ). One of these samples (MHS-66-72) was analyzed for base and precious metals. Only minor amounts of lead, zinc, and copper were noted; gold and silver were not detectable (table 21).

Eight feet north of the south-central vein is the north-central vein. This vein is only exposed for 40 feet in the floor of the main cut and probably does not continue far. It is $0.5-2.0$ feet thick. The strike of the north-central vein is parallel to that of the south-central and southern veins; its dip was not observed. The north-central vein is black and calcite is the predominant gangue mineral. This vein is identical in appearance to the south-central vein and probably similar in composition. The one sample taken of this vein had 3.83 percent $\mathrm{ThO}_{2}$ (pl. $2 \mathrm{~B}$; table 21$)$.

The northern vein differs from the other three veins in being mainly quartz and specularite. It is thus more resistant and forms massive outcrops both east and west of the small gulch. A major part of the vein on this property lies under the dump of the main cut. On the Silver Queen 52B property this vein strikes approximately N. $85^{\circ}$ E. and dips steeply. It can be traced on the property for 810 feet but probably connects with a similar vein on the Lone Star No. 2 property on strike with it 0.5 mile to the west. This vein shows considerable thickening and thinning and ranges in thickness from 2.0 to 28 feet. The northern vein varies from white to dark purplish gray in color and is brecciated. In places white quartz is fractured and filled with later dark-purplish-gray vein material of quartz and specularite. In addition, in places this vein contains limonite and thorite. Thorium content, as indicated by its radioactivity, is erratic, much of the vein having only a minor amount of thorium but parts of the vein being fairly rich in thorium. Two samples were taken on abnormally highly radioactive parts of the vein (pl. 2B). They yielded 0.27 and 0.77 percent $\mathrm{ThO}_{2}$ (table 21). 
TABLE 21.-Analyses of samples from the Silver Queen 52B property, Idaho

[C. chip sample; $\mathrm{Ch}$, channel sample; n.d., no data; <, less than]

\begin{tabular}{|c|c|c|c|c|c|c|c|c|c|}
\hline \multirow{2}{*}{$\begin{array}{l}\text { Vein } \\
\text { South }\end{array}$} & \multirow{2}{*}{$\frac{\text { Sample No. }}{\text { MHS-67-72 }}$} & \multicolumn{2}{|c|}{$\begin{array}{l}\text { Sample Length } \\
\text { and type } \\
\text { (ft) }\end{array}$} & \multirow{2}{*}{$\begin{array}{c}\begin{array}{c}\text { ThO, } \\
\text { (percent) }\end{array} \\
41.63\end{array}$} & \multirow{2}{*}{$\begin{array}{c}\begin{array}{c}\text { Copper } \\
\text { (percent) }\end{array} \\
0.001\end{array}$} & \multirow{2}{*}{$\frac{\begin{array}{c}\text { Lead' } \\
\text { (percent) }\end{array}}{0.024}$} & \multirow{2}{*}{$\frac{\begin{array}{c}\text { Zincl }^{1} \\
\text { (percent) }\end{array}}{0.022}$} & \multirow{2}{*}{$\begin{array}{c}\begin{array}{c}\text { Silver }{ }^{2} \text { (ounces } \\
\text { per short ton) }\end{array} \\
<0.6\end{array}$} & \multirow{2}{*}{$\begin{array}{c}\begin{array}{c}\text { Gold (ounces } \\
\text { per short ton) }\end{array} \\
0.0020\end{array}$} \\
\hline & & 0.6 & $\mathrm{Ch}$ & & & & & & \\
\hline & 4967 & 1.2 & $\mathrm{C}$ & 5.12 & N.d. & N.d. & N.d. & N.d. & N.d. \\
\hline & $4967 \mathrm{~A}$ & 1.5 & $\mathrm{C}$ & 52.22 & n.d. & n.d. & n.d. & n.d. & n.d. \\
\hline & MHS-65-72 & 2.0 & $\mathrm{C}$ & 4.87 & .007 & .016 & .011 & $<.6$ & .0015 \\
\hline & $5067 \mathrm{C}$ & 2.0 & $\mathrm{C}$ & 52.22 & n.d. & n.d. & n.d. & n.d. & n.d. \\
\hline & $4969 A$ & 1.8 & $\mathrm{C}$ & ${ }^{5} 1.20$ & n.d. & n.d. & n.d. & n.d. & n.d. \\
\hline & 4969 & 1.0 & C & 5.35 & n.d. & n.d. & n.d. & n.d. & n.d. \\
\hline & $5067 \mathrm{~B}$ & 2.0 & C & $s_{2.91}$ & n.d. & n.d. & n.d. & n.d. & n.d. \\
\hline & $5067 \mathrm{~A}$ & 2.0 & C & 51.03 & n.d. & n.d. & n.d. & n.d. & n.d. \\
\hline & $5063 \mathrm{~B}$ & 3.0 & C & 5.90 & n.d. & n.d. & n.d. & n.d. & n.d. \\
\hline & MHS-68-72 & 3.0 & $\mathrm{C}$ & 4.24 & n.d. & n.d. & n.d. & n.d. & n.d. \\
\hline \multirow[t]{3}{*}{ Southcentral } & .....4968 & 1.5 & C & 5.79 & n.d. & n.d. & n.d. & n.d. & n.d. \\
\hline & MHS-66-72 & 1.9 & $\mathrm{Ch}$ & ${ }^{4} 1.04$ & .001 & .010 & .004 & $<.6$ & $<.0015$ \\
\hline & $5067 \mathrm{E}$ & 1.0 & $\mathrm{C}$ & 51.07 & n.d. & n.d. & n.d. & n.d. & n.d. \\
\hline Northcentral. & .....5067D & 2.0 & $\mathrm{C}$ & 53.83 & n.d. & n.d. & n.d. & n.d. & n.d. \\
\hline \multirow[t]{2}{*}{ North ................ } & .....5063D & 3.0 & C & 5.77 & n.d. & n.d. & n.d. & n.d. & n.d. \\
\hline & $5063 C$ & 3.0 & $\mathrm{C}$ & 5.27 & n.d. & n.d. & n.d. & n.d. & n.d. \\
\hline
\end{tabular}

'Atomic-absorption analysis by J. A. Thomas, U.S. Geological Survey. Denver, Colo.

3Fire assay and atomic-absorption analysis by W. D. Goss, A W. Haubert, and J. A. Thomas, U.S.

Geological Survey, Denver, Colo.

${ }^{4}$ Gamma-ray spectrometric analysis by C. M. Bunker and C. A. Bush, U.S. Geological Survey, Denver. Colo.

sWet chemical analysis by Lucius Pitkin, Inc., Grand Junction, Colo.

\section{SILVER QUEEN 38A}

The Silver Queen 38A claim (loc. 148) lies near Wheat Spring across a northwest-trending tributary of Poison Creek which is a west-flowing tributary of Pattee Creek. This property is in the SW1/4SW1/4 sec. 17, T. 19 N., R. $28 \mathrm{E}$., Boise meridian, Idaho, and is reached by a secondary road that follows the tirbutary from Poison Creek. The Silver Queen 38A was located during the summer of 1954 by J. A. Rucker, and was one of more than 100 Silver Queen claims located by him in the mid-1950's in the Pattee Creek drainage. The property was owned in the mid 1960's by the Nuclear Fuels and Rare Metals Corp. By 1969 ownership had passed to the Joyce Corp. Workings consist of several interconnected bulldozer cuts on either side of the small tributary (fig. 30). Workings are cut in a tan fine-grained micaceous quartzite of the Precambrian Y age.

Two parallel veins are exposed on this property, but only one was noted on the west side of the tributary. Where both veins are exposed on the east side of the tributary the intervening quartzite is silicified. The large south vein can be traced for 210 feet across the creek, and is $2.0-4.5$ feet thick. This vein has a $\mathrm{N} .85^{\circ} \mathrm{E}$. strike and dips $60^{\circ} \mathrm{NW}$. The north vein has been traced only for 32 feet and is as much as 3.0 feet thick. The veins lie in a horst and are bounded both to the east and west by downdropped blocks of Challis Volcanics. A third fault, a northeast-trending cross fault that offset the horst faults, lies 700 feet to the northwest of the larger vein (pl. 1). If the veins extend far from the vicinity of the workings, then these faults might well limit their extent. The veins are generally black with some dark-brown spots and the gangue is chiefly quartz, although pink microcline is also abundant. The black color is due to numerous finely disseminated black shiny plates of specularite. Other iron oxide minerals include brown limonite, cherry-red hematite, and a little black magnetite. Reddish-brown shiny thorite is the only thorium mineral noted. The only other mineral identified was a minor amount of brown shiny rutile. Four samples were cut of the longer vein and one each of the shorter vein and of the intervening silicified country rock. The $\mathrm{ThO}_{2}$ content of the south vein ranged from 0.16 to 2.40 percent, that of the north vein and silicified country rock 0.22 and 0.05 percent, respectively (fig. 30 ; table 22 ). The total rare-earth content of one sample from the longer vein (sample 4911D), as determined by X-ray fluorescence by the U.S. Bureau of Mines at Salt Lake City, Utah, was 1.60 percent.

\section{NELLIE B}

This property (loc. 153) lies on the divide between Pattee and Agency Creeks in the NW1/4NW1/4 sec. 24, T. $19 \mathrm{~N}$., R. 24 E., Boise meridian, Idaho. It is about 1.5 miles north-northeast of the junction of Agency and Cow Creeks. Several Nellie B claims lie in this general region, and the claim number of this particular property is not known. It was located by Nuclear Fuels and Rare Metals Corp. in 1956 and was controlled by the same company in the summer of 1972 . Workings consist of three 4-foot-deep bulldozer trenches 60-200 feet long (fig. 31). The country rock is a Precambiran $\mathrm{Y}$ gray fine-grained brecciated micaceous quartzite.

Two veins are exposed in the workings. The northern one has a general strike of $\mathrm{N} .75^{\circ} \mathrm{W}$. and dips $70^{\circ} \mathrm{SW}$. This vein can be traced for about 120 feet. It probably does not continue much farther to the east, as no trace of it was found 


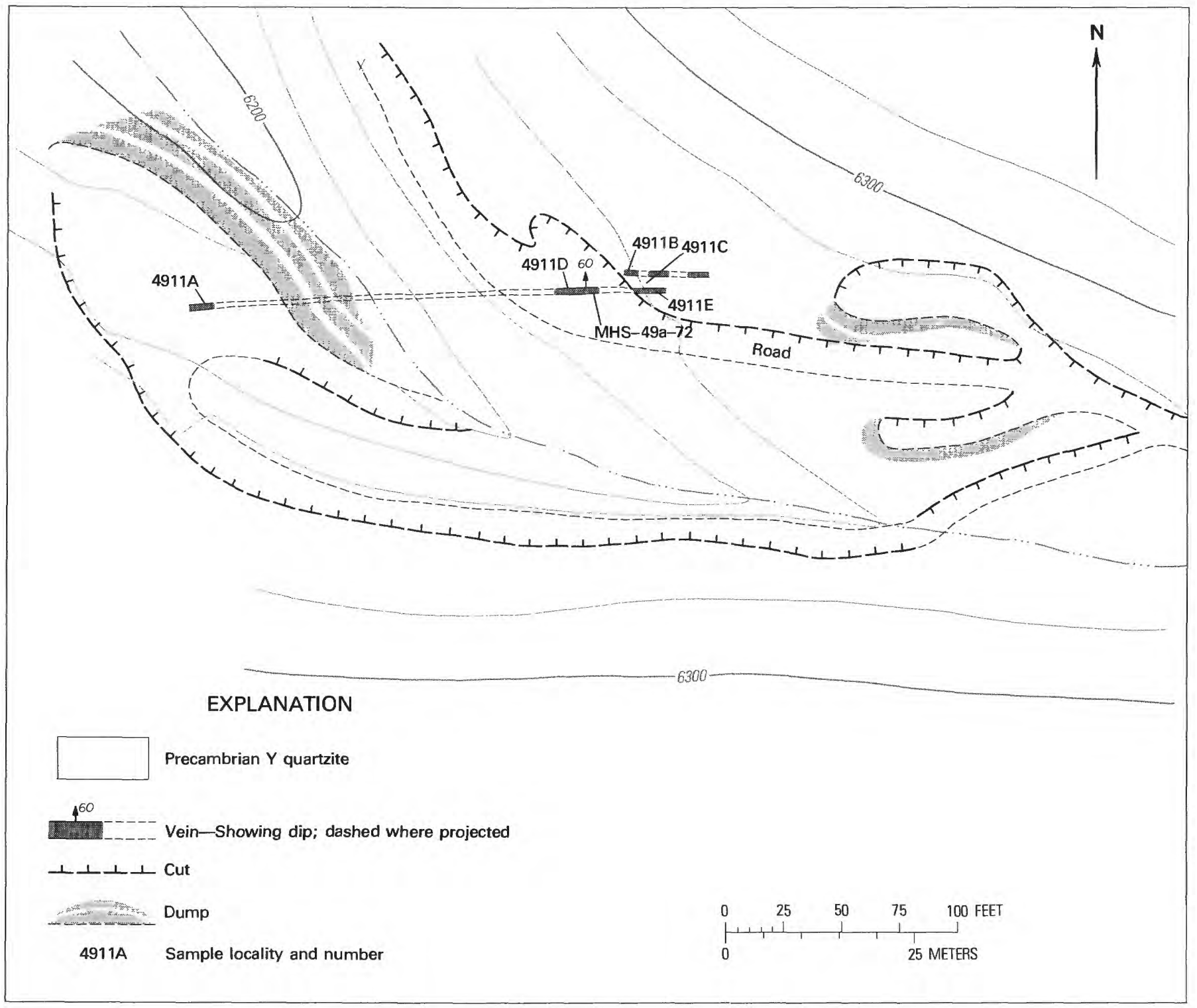

Figure 30.-Geologic map of the Silver Queen 38A property (loc. 148). Mapped by B. J. Sharp and D. L. Hetland, 1965; revised by M. H. Staatz, 1973.

TABLE 22.-Analyses of chip samples from the Silver Queen 38 A claim, Idaho

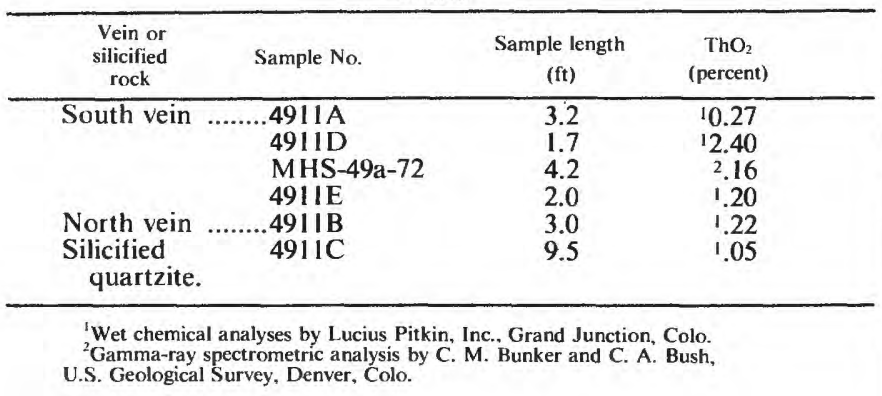

in the long northeast-trending trench (fig. 31). This vein is 0.3-1.5 feet thick. A sample (4985A) cut in the middle trench contained 0.30 percent $\mathrm{ThO}_{2}$ and 0.45 percent total rare-earth oxides (Austin, 1968, p. 10).

The second vein is only exposed in the western trench. It has a strike of $\mathrm{N} .82^{\circ} \mathrm{W}$. and may be a branch of the northern vein. It is 2.5 feet thick. A sample (4995B) of this vein yielded 0.17 percent $\mathrm{ThO}_{2}$. Both veins are dark brown and composed chiefly of limonite-stained quartz mixed with hematite.

\section{BLACK ROCK, IDAHO}

The Black Rock property (loc. 165) is on the steep north side of Agency Creek about 0.3 mile northwest of the mouth of Cow Creek in the NW1/4NW1/4 sec. 26, T. 19 N., R. 24 E., Boise meridian, Idaho. It is on the west side of a small gulch, 


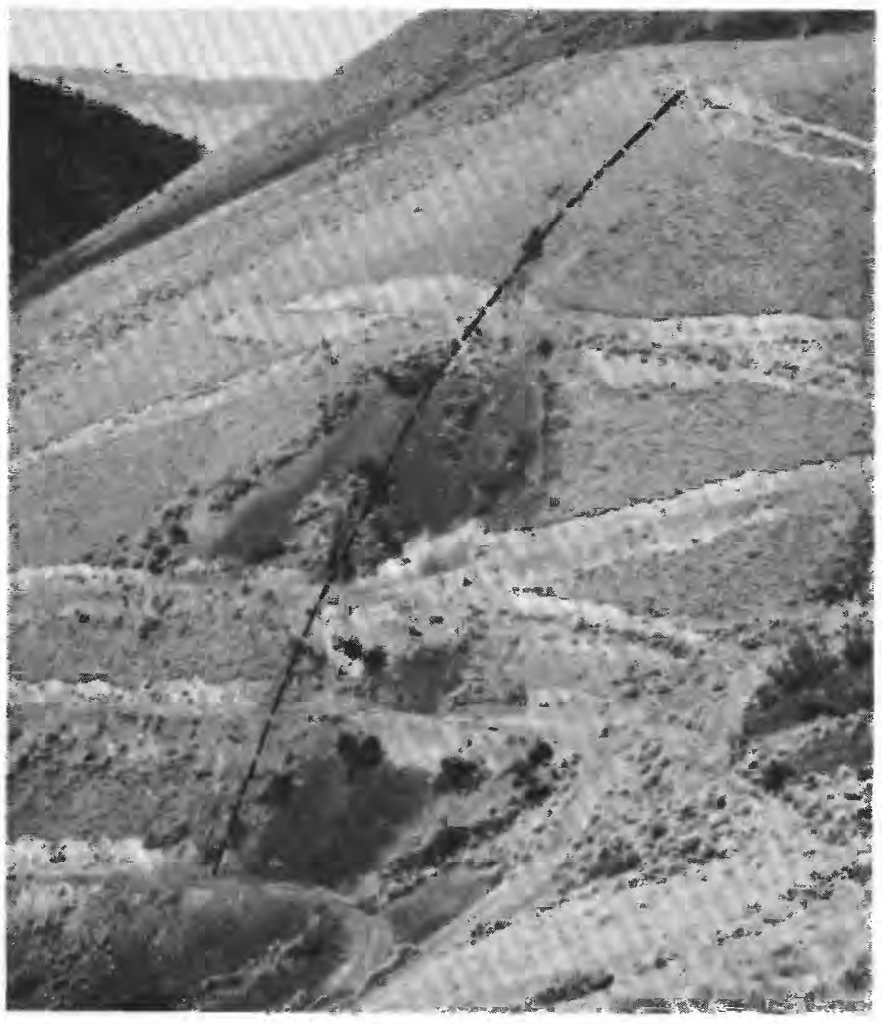

FIGUIRE 32.-Northwest-trending vein on the Black Rock, Mont., property (loc. 75) exposed by a series of bulldozer trenches.

the total exposed length would be 1,600 feet.

On the Black Rock property the northwest-trending vein strikes N. $75^{\circ}-85^{\circ} \mathrm{W}$. and dips $55^{\circ}-75^{\circ} \mathrm{SW}$. This vein is commonly brecciated and is medium to dark brown in color. It consists principally of quartz and microcline veined and cut be goethite. Other iron oxides include some black shiny plates of specularite and minor tiny grains of magnetite. This is one of the few veins which contains siderite. The only radioactive mineral noted was a little thorite. The amount of thorite noted was too minor to account for the measured thorium content, and probably some of the thorium occurs within the goethite. Other minerals identified in this vein include pyrite, chalcopyrite, malachite, barite, rutile, and apatite. Pyrite is visible in tiny cubes both in the vein and in the adjoining silicified quartzite. Five samples taken from this vein yielded from $0.16-0.62$ percent $\mathrm{ThO}_{2}$ (fig. 33; table 23 ). One of these samples (5074A) contained 0.27 percent total rare-earth oxides. Two of the samples (MHS-94-72, MHS-95-72) were analyzed for base and precious metals. They contained small amounts of copper, lead, and zinc, but did not yield any detectable gold or silver (table 23).

The northeast-trending vein is exposed for 80 feet in the highest trench. This vein is about 1 foot thick. It strikes $\mathrm{N}$. $50^{\circ}-70^{\circ} \mathrm{E}$. and dips $20^{\circ} \mathrm{NW}$. It is a medium-brown color and consists chiefly of quartz mixed with medium- to dark-brown goethite. Minor magnetite is included in some of the goethite. No thorium minerals were noted in the specimen (MHS-24-73) examined and the thorium most likely occurs within the goethite. Other minerals noted are minor amounts of barite, rutile, and fluorite. A sample from this vein had 0.21 percent $\mathrm{ThO}_{2}$ (fig. 33; table 23).

\section{$\mathrm{THO}_{2}$}

The main workings on the principal vein of the $\mathrm{ThO}_{2}$ property (loc. 192) lie at an elevation of approximately 7,850 feet in a small densely wooded northwest-trending valley of a tributary of the South Fork of Yearian Creek. This property, which is near the top and on the northwest side of the main ridge separating the Yearian Creek from the Reese Creek drainages, is in the $\mathrm{W} 1 / 2$ sec. 28, T. $18 \mathrm{~N}$., R. 25 E., Boise meridian, Idaho. A steep secondary road connecting the Lemhi Valley with the Continental Divide passes through the property. The mine road branches off a good gravel county road 4 miles southeast of where the latter joins Idaho Route 28 at Lemhi (pl. 1). A group of $16 \mathrm{ThO}_{2}$ claims were located by Carroll Wells and Ann Lundin (Anderson, 1961 b,

TABLE 23.-Analyses of chip samples from the Black Rock property, Idaho

[n.d., no data, $<$, less than]

\begin{tabular}{|c|c|c|c|c|c|c|c|c|c|}
\hline Vein & Sample No. & $\begin{array}{c}\text { Sample. } \\
\text { length } \\
\text { (tt) }\end{array}$ & $\begin{array}{c}\mathrm{ThO}_{2} \\
\text { (percent) }\end{array}$ & $\begin{array}{c}\text { Total } \\
\text { rare earths' } \\
\text { (percent) }\end{array}$ & $\begin{array}{l}\text { Copper } \\
\text { (percent) }\end{array}$ & $\begin{array}{c}\text { Lead }^{2} \\
\text { (percent) }\end{array}$ & $\underset{\text { (percent) }}{\text { Zince }^{2}}$ & $\begin{array}{l}\text { Silver }{ }^{3} \text { (ounces } \\
\text { per short ton) }\end{array}$ & $\begin{array}{l}\text { Gold }{ }^{4} \text { (ounces } \\
\text { per short ton) }\end{array}$ \\
\hline \multirow{5}{*}{$\begin{array}{l}\text { Northwest- } \\
\text { trending. }\end{array}$} & MHS-94-72 & 1.8 & ${ }^{5} 0.62$ & N.d. & 0.002 & 0.012 & 0.043 & $<0.6$ & $<0.0015$ \\
\hline & 643 & 2.5 & 6.20 & n.d. & N.d. & N.d. & N.d. & N.d. & N.d. \\
\hline & $5074 \mathrm{~A}$ & 2.5 & 6.16 & 0.27 & n.d. & n.d. & n.d. & n.d. & n.d. \\
\hline & MHS-95-72 & 1.9 & 5.40 & n.d. & .03 & .007 & .005 & $<.6$ & $<.0015$ \\
\hline & $5074 B$ & 2.0 & 6.43 & n.d. & n.d. & n.d. & n.d. & n.d. & n.d. \\
\hline $\begin{array}{l}\text { Northeast- } \\
\text { trending. }\end{array}$ & MHS-24-73 & 1.0 & 5.25 & n.d. & n.d. & n.d. & n.d. & n.d. & n.d. \\
\hline
\end{tabular}

IX-ray fluorescence spectrographic analysis by the U.S. Bureau of Mines, Salt Lake City, Utah.

2Atomic-absorption analysis by J. A. Thomas. U.S. Geological Survey. Denver, Colo.

"Fire assay and atomic-absorption analysis by W. D. Goss, A. W. Haubert, and S. A. Thomas,

U.S. Geological Survey, Denver, Colo.

sGamma-ray spectrometric analysis by C. M. Bunker and C. A. Bush, U.S. Geological Survey, Denver, Colo.

"Wet chemical analysis by Lucius Pitkin, Inc., Grand Junction, Colo. 


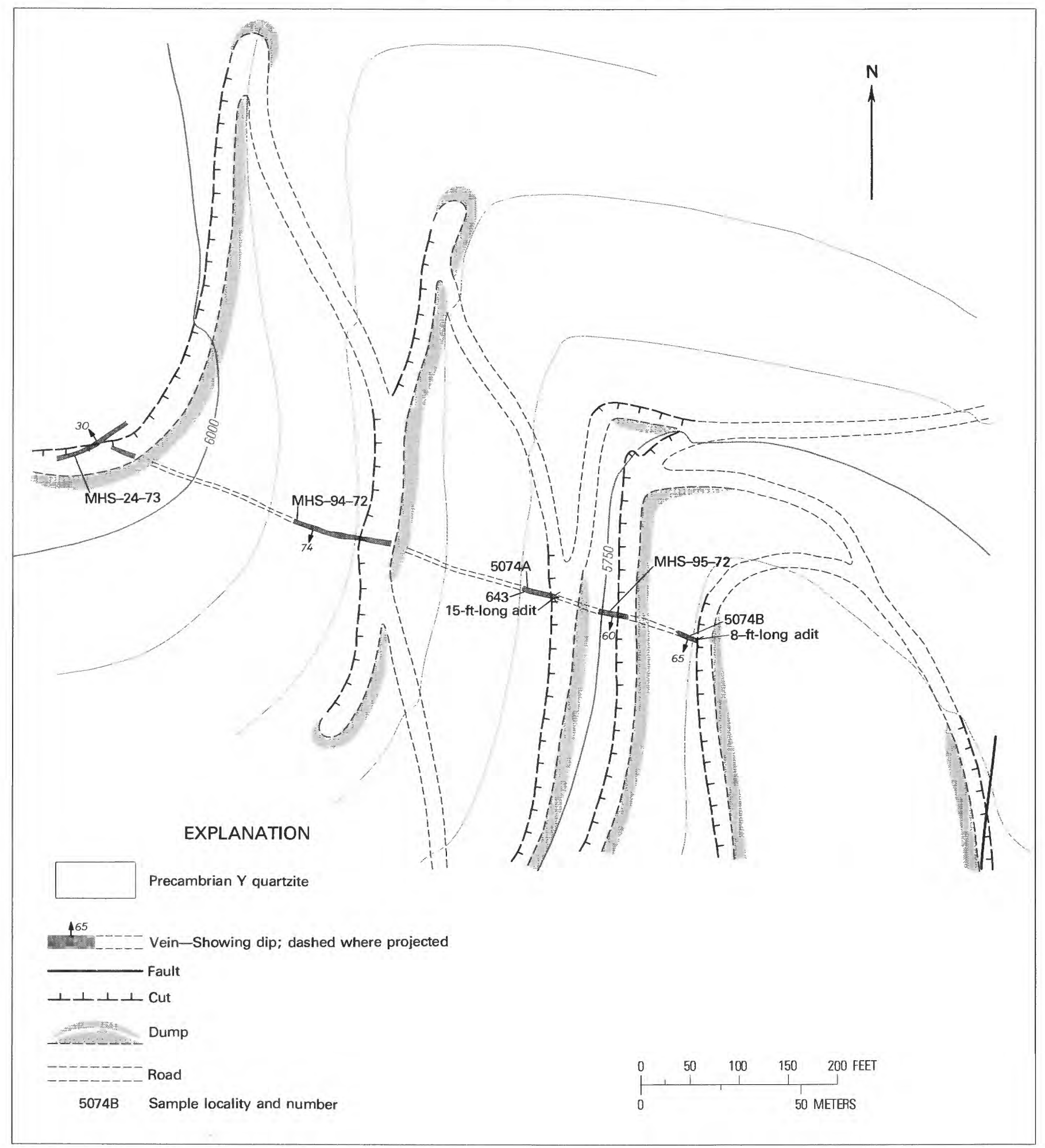

Figure 33.-Geologic map of the Black Rock, Idaho, property (loc. 165). Mapped by B. J. Sharp and D. L. Hetland, 1965; revised by M. H. Staatz, 1973.

p. 96), the first (the $\mathrm{ThO}_{2}$ ) being located June 1, 1960, and the others later during the same summer. Ownership was later transferred to the $\mathrm{ThO}_{2}$ and Rare Metals Exploration, Inc., of which Mr. Wells is president. In the 1960's the property was leased to the Dow Chemical Co. who made many bulldozer cuts and did some diamond drilling. In the late 


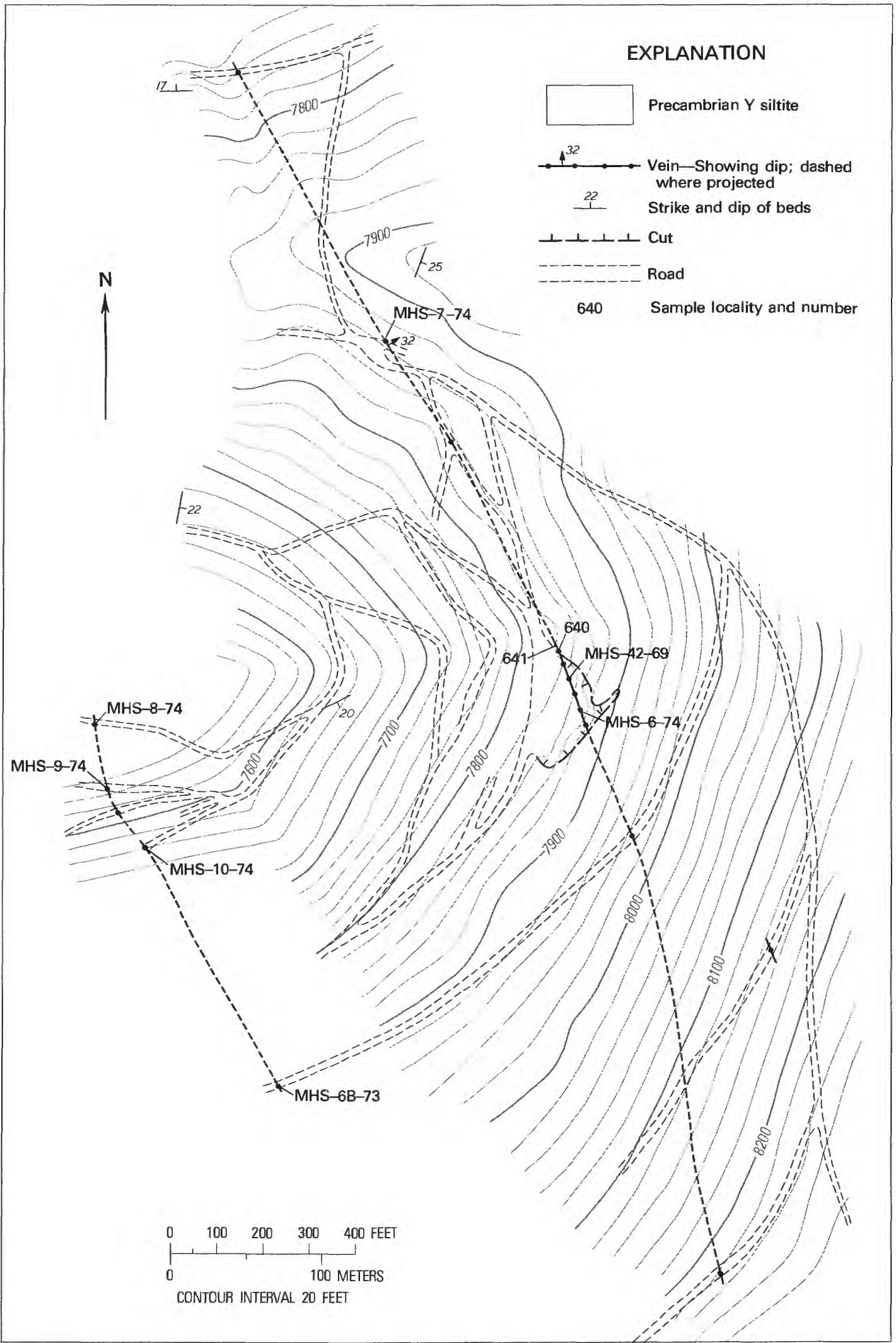

Figure 34.-Geologic map of the $\mathrm{ThO}_{2}$ property (loc. 192). Mapped by B. J. Sharp and D. L. Hetland, 1965; revised by M. H. Staatz, 1973. 
TABLE 24.-Thorium analyses of samples from the $\mathrm{ThO}_{2}$ property, Idaho [C, chip sample; G, grab sample; NA, not applicable]

\begin{tabular}{|c|c|c|c|}
\hline Vein & Sample No. & $\begin{array}{l}\text { Sample length } \\
\text { and type } \\
\text { (ft) }\end{array}$ & $\underset{\text { (percent) }}{\mathrm{ThO}_{2}}$ \\
\hline Main vein & $\begin{array}{l}\text { MHS }-7-74 \\
640 \\
641 \\
\text { MHS-42-69 } \\
\text { MHS-6-74 }\end{array}$ & $\begin{array}{rl}0.7 & \mathrm{C} \\
4.0 & \mathrm{C} \\
3.0 & \mathrm{C} \\
\mathrm{NA} & \mathrm{G} \\
.9 & \mathrm{C}\end{array}$ & $\begin{array}{c}10.032 \\
22.30 \\
2.84 \\
12.39 \\
1.51\end{array}$ \\
\hline West vein & $\begin{array}{l}\text { MHS-8-74 } \\
\text { MHS-9-74 } \\
\text { MHS-10-74 } \\
\text { MHS-68-73 }\end{array}$ & $\begin{array}{rl}1.0 & \mathrm{C} \\
.9 & \mathrm{C} \\
.7 & \mathrm{C} \\
1.3 & \mathrm{C}\end{array}$ & $\begin{array}{l}1.007 \\
1.21 \\
1.11 \\
1.61\end{array}$ \\
\hline
\end{tabular}

'Gamma-ray spectrometric analysis by C. M. Bunker and C. A. Bush, U.S. Geological Survey Denver, Colo.

Wet chemical analysis by Lucius Pitkin, Inc., Gran Junction, Colo.

1960's, Dow Chemical Co. sold its lease to the Kough Mining and Manufacturing Co. of California. One long vein and several smaller veins are found on this property. As the area has a thick soil cover, the vein exposures are restricted to various cuts. The workings consist of one large bulldozed area some 250 feet long near the center of the principal vein, and more than 13,000 feet of roads (fig. 34). The country rock is greenish-gray siltite of Precambrian $\mathrm{Y}$ age. The $\mathrm{ThO}_{2}$ property is on the east side of the Yearian Creek graben and the veins on this property lie adjacent to a northeast-trending fault that cuts the graben.

A number of veins occur on the $\mathrm{ThO}_{2}$ claims, but most appear to be small. Figure 34 shows the extent of the largest vein and parts of two others. The largest vein has an overall strike of N. $28^{\circ} \mathrm{W}$. Near its northern end the vein dips $32^{\circ}$ $\mathrm{NE}$, but along most of its length the dip is much steeper and in places is nearly vertical. This vein has been traced for 2,860 feet (fig. 34). Its thickness varies, and it apparently is thickest in the main cut, where it ranges from about 1 to 15 feet. Eight hundred feet northwest of the main cut the vein is 10 inches thick, and on the road 300 feet southeast of the cut it is about 1 foot thick. The vein is brecciated, and in places dark-red vein material surrounds white quartz augen. In some areas the entire vein is rusty brown. The principal gangue minerals are white quartz and pink feldspar. The principal iron oxide is black shiny specularite. Minor goethite and black granular magnetite are also present. Reddish-brown thorite, the principal thorium mineral, is common. Minor monazite has also been noted (Anderson, 1961b, p. 97). Other minerals include muscovite, rutile, a black manganese oxide mineral, barite, apatite, and rare pale-pink xenotime. Five samples collected from this vein (table 24; fig. 34) yielded 0.032-2.39 percent $\mathrm{ThO}_{2}$. Some of the most radioactive samples in this district have come from the main working on this vein.

Another fairly continuous vein is exposed in a series of cuts 1,040 feet west of the main pit (fig. 34). This vein has a strike of about N. $25^{\circ} \mathrm{W}$. and a steep dip. It extends for 320 feet between four closely spaced roads. A vein outcrop on a road farther southeast indicates that it extends at least another 600 feet. This vein is poorly exposed, but where visible has a thickness of 1.0-1.3 feet. The vein is yellowish brown and is brecciated. The principal gangue mineral is pink microcline; a little quartz is also present. Dark-brown goethite, black shiny specularite, and dark-red granular hematite vein and stain the feldspar. Magnetite is present in minor amounts. Reddish-brown thorite was the only thorium mineral noted. Small amounts of muscovite and rutile were also seen. Four samples from this vein (table 24; fig. 34) ranged from 0.007 to 0.61 percent $\mathrm{ThO}_{2}$.

\section{REFERENCES CITED}

Adams, J. W., 1969, Distribution of lanthanides in minerals, in Geological Survey Research 1969; U.S. Geol. Survey Prof. Paper 650-C, p. C38-C44.

Anderson, A. L., 1956, Geology and mineral resources of the Salmon quadrangle, Lemhi County, Idaho: Idaho Bur. Mines and Geology Pamph. 106, 102 p.

1957, Geology and mineral resources of the Baker quadrangle, Lemhi County, Idaho: Idaho Bur. Mines and Geology Pamph. 112, 71 p.

1958, Uranium, thorium, columbium, and rare earth deposits in the Salmon region, Lemhi County, Idaho: Idaho Bur. Mines and Geology Pamph. 115, 81 p.

1959, Geology and mineral resources of the North Fork quadrangle, Lemhi County, Idaho: Idaho Bur. Mines and Geology Pamph. 118,92 p.

1960, Geology of thorite-rare earth deposits in the Lemhi Pass region, in Joseph Newton, Denis Lemoine, C. N. Adams, A. L. Anderson, and J. A. Shively, Study of two Idaho thorite deposits: Idaho Bur. Mines and Geology Pamph. 122, p. 33-39.

1961a, Thorium mineralization in the Lemhi Pass area, Lemhi County, Idaho: Econ. Geology, v. 56, no. 1, p. 177-197.

$1961 b$, Geology and mineral resources of the Lemhi quadrangle. Lemhi County [Idaho]: Idaho Bur. Mines and Geology Pamph. 124, $111 \mathrm{p}$.

Armstrong, F. C., 1956, Some thorium prospects, Lemhi Pass area, Beaverhead County, Montana: U.S. Geol. Survey Rept. TEM-918, 31 p.

Armstrong, R. L., 1974, Geochronometry of the Eocene volcanic-plutonic episode in Idaho: Northwest Geology, v. 3, p. 1-15.

Austin, S. R., 1968, Thorium, yttrium, and rare-earth analyses, Lemhi Pass, Idaho and Montana: U.S. Atomic Energy Comm., Tech. Memo. AEC-RID-2, 12 p.

Austin, S. R., Hetland, D. L., and Sharp, B. J., 1970, Mineralogy of the Lemhi Pass thorium and rare-earth deposits: Idaho Bur. Mines and Geology Mineral Resources Rept. 11, 10 p.

Axelrod, D. I., 1966, Potassium-argon ages of some western Tertiary floras: Am. Jour. Sci., v. 264, no. 7. p. 497-506.

Clark, S. P., Jr., Peterman, Z. E., and Heier, K. S., 1966, Abundances of uranium, thorium, and potassium, in S. P. Clark, Jr., ed., Handbook of physical constants: Geol. Soc. America Mem. 97, p. 521-541.

Geach, R. D., 1966, Thorium deposits of the Lemhi Pass district, Beaverhead County, Montana: Montana Bur. Mines and Geology Spec. Pub. 41, 22 p.

Grout, F. F., 1932, Petrography and petrology-A textbook: New York, McGraw-Hill Book Co., Inc., 522 p.

Harrison, J. E., and Campbell, A. B., 1963, Correlations and problems in Belt Series stratigraphy, northern Idaho and western Montana: Geol. Soc. America Bull., v. 74 , no. 12, p. 1413-1427.

Jarrard, L. D. 1957, Some occurrences of uranium and thorium in Montana, with sections on prospecting for radioactive minerals: Montana Bur. Mines and Geology Misc. Contr. 15, 90 p. 
Larsen, F. S., 3d, and Gottfried, David, 1960, Uranium and thorium in selected suites of igneous rocks: Am. Jour. Sci., v. 258-A (Bradley Volume), p. 151-169.

Moen, W. S., 1957, Some thorium deposits in western Montana and east-central Idaho: U.S. Atomic Energy Comm. Rept. RME-2061 (pt. 1), $31 \mathrm{p}$.

Rittmann, Alfredo, 1952, Nomenclature of volcanic rocks proposed for the use in the catalogue of volcanoes, and key tables for the determination of volcanic rocks: Bull. Volcanol., ser. 2, v. 12, p. 75-102; discussion, p. 24-26.

Ross, C. P., 1927, Ore deposits in Tertiary lava in the Salmon River Mountains, IGaho: Idaho Bur. Mines and Geology Pamph. 25, 21 p. 1930, Geology and ore deposits of the Seafoam, Alder Creek. Little Smoky, and Willow Creek mining districts, Custer and Camas Counties, Idaho: Idaho Bur. Mines and Geology Pamph. 33, 26 p. 1934, Geology and ore deposits of the Casto quadrangle, Idaho: U.S. Geol. Survey Bull. 854, 135 p.

1947, Geology of the Borah Peak quadrangle, Idaho: Geol. Soc. America Bull., v. 58, No. 12, p. 1085-1160.

1961, A redefinition and restriction of the term Challis Volcanics, in hort papers in the geologic and hydrologic sciences: U.S. Geol. - urvey Prof. Paper 424-C, p. C177-C180.

1962, Stratified rocks in south-central Idaho: ldaho Bur. Mines and Geology Pamph. 125, 126 p.

Ross, J. R., and George, D. R., 1966, Metallurgical amenability tests on Idaho-Montana thorium ores: U.S. Bur. Mines Salt Lake City Metallurgy Research Center Research Rept. 62-1, 34 p.

Ruppel, E. T., 1968, Geologic map of the Leadore quadrangle, Lemhi County, Idaho; U.S. Geol. Survey Geol. Quad. Map GQ-733.

1975. Precambrian Y sedimentary rocks in east-central ldaho, Chap. A of Precambrian and Lower Ordovician rocks in east-central ldaho: U.S. Geol. Survey Prof. Paper 889, p. 1-23.

Sandberg, C. A., 1975, McGowan Creek Formation, new name for Lower Mississippian flysch sequence in east-central Idaho: U.S. Geol. Survey Bull. 1405-E, 11 p.

Sandberg, C. A., Hall, W. E., Batchelder, J. N., and Axelsen, Claus, 1975, Stratigraphy, conodont dating, and paleotectonic interpretation of the type Milligen Formation (Devonian), Wood River area, ldaho: U.S Geol. Survey Jour. Research, v. 3, no. 6, p. 707-720.

Schipper, W. B., 1955, The Tendoy Copper Queen Mine [Idaho]: Moscow, Idaho, Idaho Univ. M.S. thesis, $38 \mathrm{p}$.

Scholten, Robert, Keenmon, K. A., and Kupsch, W. O., 1955, Geology of the Lima region, southwestern Montana and adjacent Idaho: Geol. Soc. America Bull., v. 66, no. 4, p. 345-404.

Sharp, B. J., and Hetland, D. L., 1968, Thorium and rare-earth resources of the Lemhi Pass area, Idaho and Montana: U.S. Atmoic Energy Comm. Tech. Memo. AEC-RID-3, 13 p.
Sharp, W. N., and Cavender, W. S., 1962, Geology and thorium-bearing deposits of the Lemhi Pass area, Lemhi County, Idaho, and Beaverhead County, Montana: U.S. Geol. Survey Bull. 1126, 76 p.

Shenon, P. J., and McConnel, R. H., 1940, Use of sedimentation features and cleavage in the recognition of overturned strata: Econ. Geology, $v$. 35 , no. 3, p. 430-444.

Shively, J. A., 1960, Beneficiation of low-grade thorite ore from Lemhi County, in Joseph Newton, Denis LeMoine, C. N. Adams, A. L. Anderson, and J. A. Shively, Study of two Idaho thorite deposits: Idaho Bur. Mines and Geology Pamph. 122, p. 41-51.

Staatz, M. H., 1972, Geology and description of the thorium-bearing veins, Lemhi Pass quadrangle, Idaho and Montana: U.S. Geol. Survey Bull. $1351,94 \mathrm{p}$.

1973, Geologic map of the Goat Mountain quadrangle, Lemhi County, Idaho, and Beaverhead County, Montana: U.S. Geol. Survey Geol. Quad. Map GQ-1097.

1974, Thorium veins in the United States: Econ. Geology, v. 69, no. 4, p. 494-507.

Staatz, M. H., Bunker, C. M., and Bush, C. A., 1971, Geochemical prospecting for thorium veins by stream-sediment sampling, Lemhi Pass quadrangle, Idaho and Montana, in Geological Survey Research 1971: U.S. Geol. Survey Prof. Paper 750-C, p. C136-C140.

Staatz, M. H., Adams, J. W., and Wahlberg, J. S., 1976, Brown, yellow, orange, and greenish-black thorites from the Seerie pegmatite, Colorado: U.S. Geol. Survey Jour. Research, v. 4, no. 5, p. 575-582.

Staatz, M. H., Shaw, V. E., and Wahlberg, J. S., 1972, Occurrence and distribution of rare earths in the Lemhi Pass thorium veins, Idaho and Montana: Econ. Geology, v. 67, no. 1, p. 72-82.

Trites, A. F., Jr., and Tooker, E. W., 1953, Uranium and thorium deposits in east-central ldaho and southwestern Montana: U.S. Geol. Survey Bull. 988-H, p. 157-209.

Umpleby, J. B., 1913, Geology and ore deposits of Lemhi County, Idaho: U.S. Geol. Survey Bull. 528, 182 p.

1917, Geology and ore deposits of the MacKay region, Idaho: U.S. Geol. Survey Prof. Paper 97, 129 p.

Vhay, J. S., 1951, Reconniassance examination for uranium at six mines and properties in Idaho and Montana: U.S. Geol. Survey Rept. TEM 30-A, $21 \mathrm{p}$.

Weed, W. H., 1926, The mines handbook: New York, Walter Weed, Publisher, v. 17, 2129 p.

Weis, P. L., Armstong, F. C., and Rosenblum, Samuel, 1958, Reconnaissance for radioactive minerals in Washington, Idaho, and western Montana-1952-1955: U.S. Geol. Survey Bull. 1074-B, 48 p.

Wentworth, C. K., 1922, A scale of grade and class terms for clastic sediments: Jour. Geology, v. 30, no. 5, p. 377-392.

Wilson, J. A., 1946, Preliminary notice of a new Miocene vertebrate locality in Idaho [abs]: Geol. Soc. America Bull., v. 57, no. 12, pt. 2, p. 1262. 


\section{INDEX}

[Page numbers of major references are in italic]

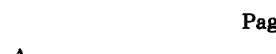

Page

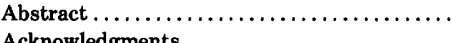

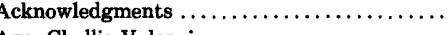

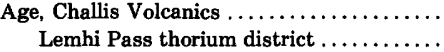

Madison Limestone ....

sanidine-quartz welded tuff .........................

tuffaceous sedimentary rocks . ......... 23,24

Agency Creek $\ldots \ldots \ldots \ldots \ldots 4,8,10,12,13,15,16,18$ $19,20,21,22,25,28,29,32,34,53$ $55,57,58,62,77,78,79$

Agency Creek fault ................... 33 Agency Creek Thorium and Rare Metals Co. .. $\quad 62$ Albite $\ldots \ldots \ldots \ldots \ldots \ldots \ldots \ldots \ldots \ldots \ldots \ldots, \quad 18,20$ Allanite $\ldots \ldots \ldots \ldots \ldots \ldots \ldots \ldots \ldots \ldots \ldots, 54,55,62$ Alluvial fans . . . . . . . . . . . . . . . . . . 26, 30 Alluvium $\ldots \ldots \ldots \ldots \ldots \ldots \ldots \ldots \ldots \ldots 6,26,28,29,33$ Anatase $\ldots \ldots \ldots \ldots \ldots \ldots \ldots \ldots \ldots \ldots, 45,69$

Anderson, A. L., quote $\ldots \ldots \ldots \ldots \ldots \ldots \ldots \ldots, 12,23$

Andesine $\ldots \ldots \ldots \ldots \ldots \ldots \ldots \ldots \ldots \ldots \ldots \ldots, \quad 18,25$

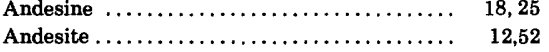

Andesitic flow $\ldots \ldots \ldots \ldots \ldots \ldots \ldots \ldots \ldots \ldots, \quad 52,53$

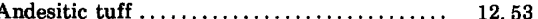

Angular unconformity $\ldots \ldots \ldots \ldots \ldots \ldots, 13,22,23,33$ Anorthite $\ldots \ldots \ldots \ldots \ldots \ldots \ldots \ldots \ldots \ldots \ldots, 18,20$ Apatite $. \ldots \ldots \ldots \ldots \ldots \ldots \ldots, 8,10,11,26,43,45,53$, $55,61,62,64,68,69,71,74,76,80,83$

Apex ..................................

Beaverhead, Montana vein ........... 64

Black Bear No. 2 .................. 61

$\begin{array}{ll}\text { Black Rock, Montana vein } \ldots \ldots \ldots \ldots \ldots \ldots & 68 \\ \text { Black Rock property ................... } & 80\end{array}$

Cago No. 12

Elkhorn

Last Chance vein $\ldots \ldots \ldots \ldots \ldots \ldots \ldots \ldots$

Lone Star No. 2

Lucky Horseshoe

Silver Queen 52B

$\mathrm{ThO}_{2}$ vein

Wonder No. 18

Apex vein .

Aphanitic volcanic rock

$\begin{array}{lr}\text { Apple Creek } \ldots \ldots \ldots \ldots \ldots \ldots \ldots \ldots \ldots \ldots \ldots & 11 \\ \text { Apple Creek Formation } \ldots \ldots \ldots \ldots \ldots \ldots \ldots & 7,8,9\end{array}$

Gunsight Formation $\ldots \ldots \ldots \ldots \ldots \ldots \ldots, \quad 8$

mineralogy $\ldots \ldots \ldots \ldots \ldots \ldots \ldots \ldots \ldots, \quad 8$

$\begin{array}{lr}\text { Apple Creek Phyllite } \ldots \ldots \ldots \ldots \ldots \ldots \ldots \ldots \ldots & 7,11 \\ & \end{array}$

Artis, Lowell, analyst $\ldots \ldots \ldots \ldots \ldots \ldots \ldots \ldots, \quad 20$

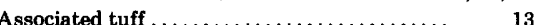

Atomic Blast ................................

Augen-shaped bodies ................... 54, 83

Augite........................... 16, 18, 26

Azurite $. . \ldots \ldots \ldots \ldots \ldots \ldots \ldots \ldots \ldots \ldots \ldots, 46,51,61$

\section{B}

Baker Quadrangle $\ldots \ldots \ldots \ldots \ldots \ldots \ldots \ldots \ldots, 7,23,25$ Barbara vein.......

$46,48,49,59$ Barite $40,42,43,44,49,51,52,55$, $57,59,61,62,64,68,69,71$. $74,75,76,80,83$

Apex $\ldots \ldots \ldots \ldots \ldots \ldots \ldots \ldots \ldots \ldots, \quad r \ldots \ldots \ldots, 74$

Black Bear No. $2 \ldots \ldots \ldots \ldots \ldots \ldots \ldots \ldots \ldots, 59,61$

Black Bull No. 3 .

Black Rock, Montana vein .............
Barite-Continued

Black Rock property

Bluebird .

Cago No. 12 .

Dan Patch .

Deer Fraction $1 \mathrm{~A}$

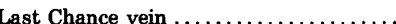

Lone Star No.

Lucky Horseshoe..

Reactor

Silver Queen 52B

$\mathrm{ThO}_{2}$ vein ....

Wonder No. 18

Basal conglomerate.

Challis Volcanics

14

Basalt . . . . . . . . . . . . . . . 12, 13, 16, 17, 22, 26, 69 younger $\ldots \ldots \ldots \ldots \ldots \ldots \ldots \ldots \ldots \ldots, 22,30$

Basalt flow. .

$13,14,16,17,18$ $19,21,22,30$

Bear Creek ........ 2, 3, 4, 10, 16, 22, 25, 27, 29, 69, 70 Bear Gulch ........................ 69

Beaverhead County, Montana ............ 2,5

Beaverhead Formation, correlation .......... 24

Beaverhead Mountains ........... 2, 6, 7, 11, 23, 28

Beaverhead vein $. \ldots \ldots \ldots \ldots \ldots \ldots \ldots \ldots, 42,50,62,63$

Bedding planes ........................ 34

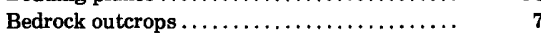

Belt Series .........

Belt Supergroup ........... 7, 34

Bentonite ................ 23, 24, 29

Big Creek Formation................. 7, 8, 11, 28, 30 Goat Mountain ................... 8 Madison Limestone .................. $\quad 11$ mineralogy $\ldots \ldots \ldots \ldots \ldots \ldots \ldots \ldots \ldots \ldots, \quad 8$ mineralogy structure.

Big Dry Gulch.

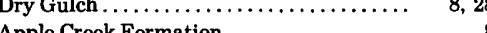

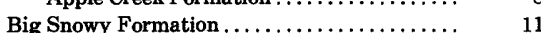

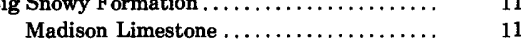

Biotite............ 9, 10, 11, 15, 16, 18, 20, 21, 22 $26,28,54,69,71,74$

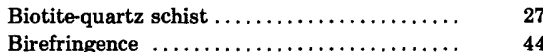

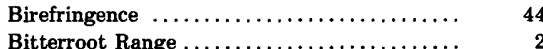

Black Bear No. $2 \ldots \ldots \ldots \ldots \ldots \ldots \ldots, 45,46,49$

Black Bull Fraction No. $4 \ldots \ldots \ldots \ldots \ldots \ldots, 50,57$

Black Bull vein $\ldots \ldots \ldots \ldots \ldots \ldots \ldots \ldots \ldots, 2,40,42,43,50$

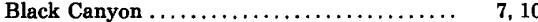

Black Canyon Creek .................. 4, 10

Black Rock, Idaho property ....... 39, 40, 45, 46, 78,

Montana property

$39,40,45,46$

$47,48,49,65,67$

Blue Boar vein $\ldots \ldots \ldots \ldots \ldots \ldots \ldots \ldots \ldots, \quad 51,52$

Blue Ridge vein ...................... 52

Bluebird vein $\ldots \ldots \ldots \ldots \ldots \ldots \ldots \ldots \ldots \ldots, \quad 51$

Bornite $. . \ldots \ldots \ldots \ldots \ldots \ldots \ldots \ldots \ldots \ldots \ldots \ldots \ldots, 51$

Brecciation.............

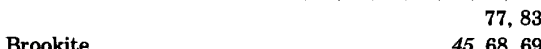

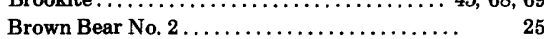

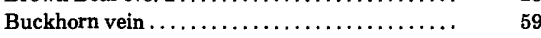

Buffalo vein $\ldots \ldots \ldots \ldots \ldots \ldots \ldots \ldots \ldots \ldots \ldots \ldots, 49,50,53,55,56$

Bull Canyon ........................

Bull Moose fault $\ldots \ldots \ldots \ldots \ldots 1,25,26,32,33,34,40$,
Page

Bull Moose vein $\ldots \ldots \ldots \ldots \ldots \ldots \ldots \ldots \ldots, \quad 42,67$ Bunker, C. M., analyst......... $47,52,55,59,61,62$, $63,65,68,69,71,76,77,78,80,83$

Bush, C. A., analyst ......... 47, 52, 55, 59, 61, 62 , $63,65,68,69,71,76,77,78,80,83$

Cago No. 10 vein $. \ldots \ldots \ldots \ldots \ldots \ldots \ldots \ldots \ldots, \quad 35$ Cago No. 12 vein $\ldots \ldots \ldots \ldots \ldots \ldots \ldots, 39,42,50,62,63$ Calcite $\ldots \ldots \ldots \ldots \ldots \ldots \ldots .17,26,42,43,51,52,53,55$ $56,57,59,61,68,69,74,76$

Apex $\ldots \ldots \ldots \ldots \ldots \ldots \ldots \ldots \ldots \ldots, \quad 74$

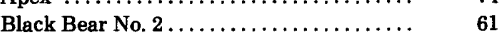
Black Bull No. $3 \ldots \ldots \ldots \ldots \ldots \ldots \ldots \ldots, \quad 57$

Black Rock, Montana vein ............ 68

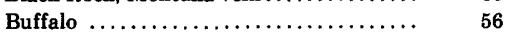

Copper Queen ....................... $\quad 51$

Deer Fraction $1 \mathrm{~A} . \ldots \ldots \ldots \ldots \ldots \ldots \ldots \ldots \ldots$

Last Chance vein $\ldots \ldots \ldots \ldots \ldots \ldots \ldots, \quad 69$

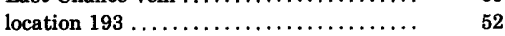

Lucky Horseshoe .....................

Silver Queen 52B .................. $\quad 76$

Calcite-hematite vein $\ldots \ldots \ldots \ldots \ldots \ldots \ldots \ldots, \quad 76$

Camas County, Idaho ..................... $\quad 2$

Camp Creek $\ldots \ldots \ldots \ldots \ldots \ldots \ldots \ldots \ldots \ldots \ldots, 59,60,61,62$

Camp Creek Canyon .................. 60, 61

Carbonates ......................... 43

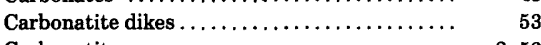

Carbonatites $\ldots \ldots \ldots \ldots \ldots \ldots \ldots \ldots \ldots \ldots \ldots, \quad 2,53$

Cedar Gulch ..........................

Chalcedony $\ldots \ldots \ldots \ldots \ldots \ldots \ldots \ldots \ldots \ldots, 17,52$

Chalcopyrite $\ldots \ldots \ldots \ldots \ldots \ldots, 46,51,53,55,61,62,76,80$

Copper Queen .................... 51

Idaho Pride $. . \ldots \ldots \ldots \ldots \ldots \ldots \ldots \ldots, \quad 51$

Last Chance ........................ 51

Challis $\ldots \ldots \ldots \ldots \ldots \ldots \ldots \ldots \ldots \ldots \ldots, \quad 12$

Challis outcrop ........................ 14

Challis Volcanic Group .................. 12

Challis Volcanics $\ldots \ldots \ldots \ldots \ldots 4,6,12,13,14,16,18,21$ $22,23,24,26,28,29,31,32,33,34$, $48,52,53,55,77$

age $\ldots \ldots \ldots \ldots \ldots \ldots \ldots \ldots \ldots \ldots \ldots \ldots, \quad 22$

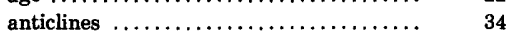

basal conglomerate .................. 14

conglomerate of Flume Creek .......... 14

distribution $\ldots \ldots \ldots \ldots \ldots \ldots \ldots \ldots, 13$

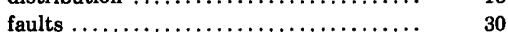

lithology $\ldots \ldots \ldots \ldots \ldots \ldots \ldots \ldots \ldots \ldots, 12,13$

potassium-argon age $\ldots \ldots \ldots \ldots \ldots \ldots \ldots, 22,23$

quartz-bearing rhyolite tuff $\ldots \ldots \ldots \ldots \ldots, \quad 14$

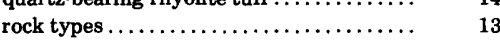

synclines $\ldots \ldots \ldots \ldots \ldots \ldots \ldots \ldots \ldots \ldots \ldots, \quad 34$

Cheney Volcanics ..................... 12

Chert $\ldots \ldots \ldots \ldots \ldots \ldots \ldots \ldots \ldots \ldots \ldots \ldots, 8,11,27,28$

Chert lenses ................................. 11

Chert matrix $\ldots \ldots \ldots \ldots \ldots \ldots \ldots \ldots \ldots \ldots, \quad 11$

Chief Tendoy claims .................. 40,49

Chlorite $\ldots \ldots \ldots \ldots \ldots 8,10,11,18,24,26,34,52,53,61$ Chrysocolla $\ldots \ldots \ldots \ldots \ldots \ldots \ldots \ldots \ldots \ldots \ldots, 51,61,68$ Cirques .............................. 3, 27

Clark Canyon Reservoir ................ 2, 4

Clasts $\ldots \ldots \ldots \ldots \ldots \ldots \ldots \ldots \ldots 15,18,20,21,26,27,28$ Clay $\ldots \ldots \ldots \ldots \ldots \ldots \ldots \ldots \ldots \ldots \ldots \ldots, 27,28,29$ Clay minerals $\ldots \ldots \ldots \ldots \ldots \ldots \ldots \ldots \ldots, \quad 52$

Cleavage $\ldots \ldots \ldots \ldots \ldots \ldots \ldots \ldots \ldots \ldots \ldots \ldots, \quad 34,43$ 


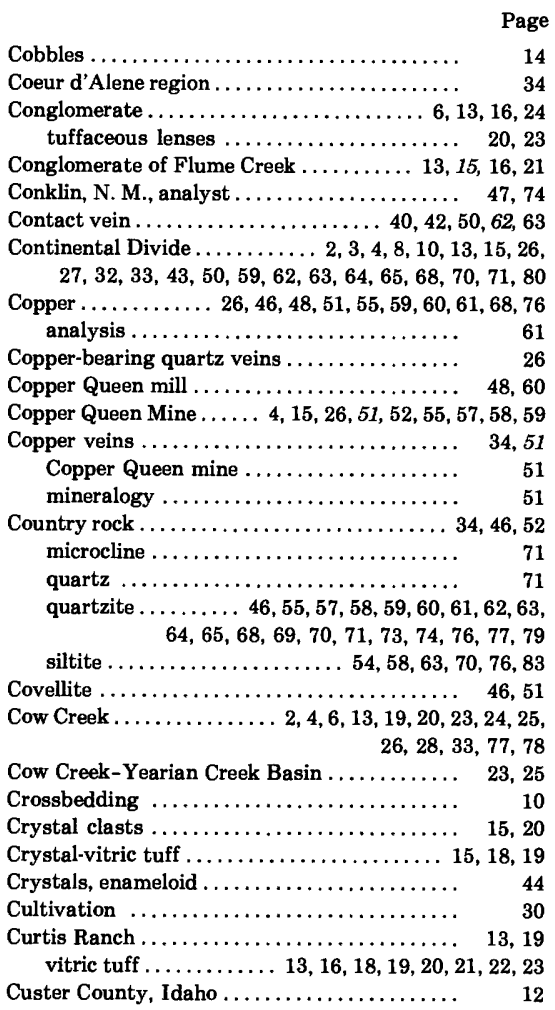

\section{D, E}

Dacite

Daisy Nielson ranch, stringers

Daisy Nielsen vein

Dan Patch fault .

........... 34 $13,16,22,31,32,34,40$ $42,57,60,62,63,64,65,69$

Dan Patch veins . . . . . .

Deer Fraction 1A . . . . . . . . . . . . . . 39, 45, 58

Defense Metals Inc.

Deposits, landslide .....................

older glacial

terrace. .

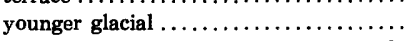

Desborough, G. A., analyst, thorium minerals

Diamond Creek area $\ldots \ldots \ldots \ldots \ldots \ldots \ldots \ldots$

Diastrophism

Dikes, syngetic .......................

Dillon ...............................

Diorite, dikes $\ldots \ldots \ldots \ldots \ldots \ldots \ldots \ldots \ldots 6,25,26,52,61$

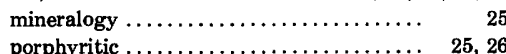

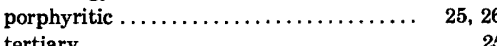

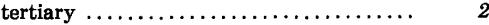

$\begin{array}{lr}\text { Dolomite } \ldots \ldots \ldots \ldots \ldots \ldots \ldots \ldots \ldots \ldots \ldots \ldots \ldots & 6 \\ \text { Dow Chemical Co. } \ldots \ldots \ldots \ldots \ldots \ldots \ldots \ldots \ldots & \mathbf{8 1}, 83\end{array}$

Dry Canyon $\ldots \ldots \ldots \ldots \ldots \ldots \ldots \ldots \ldots \ldots, 5$

Earthquakes $\ldots \ldots \ldots \ldots \ldots \ldots \ldots \ldots \ldots \ldots \ldots, \quad 29$

Elkhorn Mining Co. ...................... 68

Elkhorn vein $\ldots \ldots \ldots \ldots \ldots \ldots \ldots \ldots \ldots \ldots, 42,47,71$

Empire Explorations ...................

Enameloid crystals $\ldots \ldots \ldots \ldots \ldots \ldots \ldots \ldots \ldots, 44,65$

Engelman, E. E., analyst ............... 20

Epidote $\ldots \ldots \ldots \ldots \ldots \ldots \ldots \ldots \ldots \ldots 8,10,26,54,61$

Europium .

Everson Creek ...................... 25 North Fork $\ldots \ldots \ldots \ldots \ldots \ldots \ldots \ldots \ldots \ldots \ldots \ldots \ldots, 26,29,70$

F

Faulted graben $\ldots \ldots \ldots \ldots \ldots \ldots \ldots \ldots \ldots \ldots, \quad 13$
Faults $\ldots \ldots \ldots \ldots \ldots \ldots, 8,29,30,31,40,50,52,77,82$ Agency Creek .................... Bull Moose.
Faults-Continued

Dan Patch

Lemhi Pass $\ldots \ldots \ldots \ldots \ldots \ldots \ldots \ldots \ldots \ldots \ldots, 8,31,40$

Pattee Creek ..................... 13, 33, 52

Peterson Creek thrust................. 8

Reese Creek .......................

steep ....

structure

Yearian Creek $\ldots \ldots \ldots \ldots \ldots \ldots \ldots \ldots, 31,33$

Feldspar $\ldots \ldots \ldots \ldots \ldots \ldots \ldots .8,9,10,18,21,22,24,30$

$\mathrm{ThO}_{2}$ vein

$40,43,59,75,76,83$

Feldspathic quartzite, Big Creek Formation...

Flora, Abies lasiocarpa

Acer glabrum.

Alnus tenuifolia.

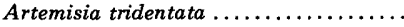

Betula occidentalis. .

Chrysothamnus nausesus.

Cornus stolonifera

Philadelphus

Physocarpus capitatus

Picea engelmanni...

Pinus contorta var. latifolia

Pinus flexilis

Populus balsamifera

Populus tremuloides

Prunus virginiana

Psudotsuga menziesii ..................

Ribes inerme.

Ribes viscosissimum .................

Rosa woodsii.

Sambucus coerulea....................

Symphoricarpos occidentalis

willows

Flow breccia $\ldots \ldots \ldots \ldots \ldots \ldots \ldots \ldots \ldots \ldots, 17,18,21,22$

Flow-breccia unit .................... 13, 16, 19, 20, 21

Flow rock $\ldots \ldots \ldots \ldots \ldots \ldots \ldots \ldots .12,17,28,29,30,53$

holocrystalline

phenocrysts $\ldots \ldots \ldots \ldots \ldots \ldots \ldots \ldots \ldots \ldots \ldots, 18,20,21,22$
ume Creek $\ldots \ldots \ldots \ldots \ldots 10,13,14,15,16,24,28,33$

Flume Creek $\ldots \ldots \ldots \ldots \ldots 10,13,14,15,16,24,28,33$
$53,54,55,59,71$

conglomerate .................. 13, 15, 16, 21

Flume Creek-Agency Creek area .......... 34

Fluorite $\ldots \ldots \ldots \ldots \ldots \ldots \ldots \ldots \ldots, 45,55,65,74,76,80$
Folding $\ldots \ldots \ldots \ldots \ldots \ldots \ldots \ldots \ldots \ldots \ldots \ldots, \quad 33,34$

Fossils ............................ 22, 24, 25

Acer mysticum ...................... 24, 25

Alnus jarbidgana .................. 24, 25

Alticamelus sp. .................... $\quad 25$

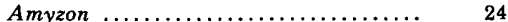

Crataegus copena ......................

Ginkgo sp. .........................

Mehonia cuprovallis ................. 24, 25

Merychyus .........................

Metasequoia sp. ..................... 24

Mylagaulus sp. ..................... $\quad 25$

Parahippus sp. .................... $\quad 25$

Picea sp. $\ldots \ldots \ldots \ldots \ldots \ldots \ldots \ldots \ldots . \ldots \ldots, 24$

Promerychocherus sp.

Quercus sp.........................

Rhus cf. R. obscura .

Sassafras hesperia ...................

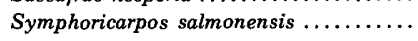

Taxodium sp.....

Ticholeptus sp. .....................

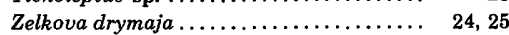

Fractures

conchoidal

. 44

South Fork $\ldots \ldots \ldots \ldots \ldots \ldots \ldots \ldots \ldots \ldots, \quad 27$

Frying Pan vein $\ldots \ldots \ldots \ldots \ldots \ldots \ldots \ldots \ldots \ldots, 39,42,48$

\section{G}

$\mathrm{G} \& \mathrm{G}$ veins

Galena
$25,39,42,50$

$46,49,62$
Gangue minerals

barite ............................... $59,61,69$

calcite $\ldots \ldots \ldots \ldots \ldots \ldots \ldots \ldots 42,43,56,57,61,74$

carbonates $\ldots \ldots \ldots \ldots \ldots \ldots \ldots \ldots \ldots \ldots, 43$

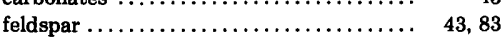

Hall Mountain area

microcline..... 42, 49, 54, 55, 56, 59, 62, 63, 65, 68,

$69,71,74,75,76,77,83$

Mountain Pass region ............... 43

Powderhorn Mountain district ........4 43, 45 quartz ...... 43, 54, 55, 56, 57, 58, 59, 61, 62, 63 $64,65,68,69,71,74,75,77,80,83$

siderite $\ldots \ldots \ldots \ldots \ldots \ldots \ldots \ldots \ldots \ldots \ldots, 43,6$

Geertson Formation ................................ 23

Germer Tuffaceous Member ............ 12, 22

Ghoul Basin ................... 16, 22, 27, 32

Ghoul Basin Spring ....................

Gilmore Quadrangle .................... 7

Glacial deposits, older ................... 6,26

younger $\ldots \ldots \ldots \ldots \ldots \ldots \ldots \ldots \ldots \ldots, 6,26,27$

Glacial river gravels ...................

Glacial till $\ldots \ldots \ldots \ldots \ldots \ldots \ldots \ldots \ldots \ldots, 26,27$

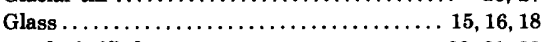

devitrified $\ldots \ldots \ldots \ldots \ldots \ldots \ldots \ldots \ldots \ldots 20,21,22$

Gneiss, banded .

Goat Mountain .............. 2, 5, 7, 8, 13, 28, 30

Big Creek Formation...

Goat Mountain Quadrangle......... 5, 7, 11, 25, 30

Goethite ...... 44, 53, 58, 62,63, 65, 69, 71, 76, 80, 83

Beaverhead, Montana vein ............ 63

Black Rock property ................. $\quad 80$

Cago No. $12 \ldots \ldots \ldots \ldots \ldots \ldots \ldots \ldots$.

Contact ....

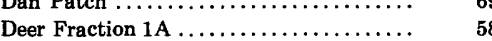

Elkhorn $. \ldots \ldots \ldots \ldots \ldots \ldots \ldots \ldots \ldots, \quad 71$

Last Chance vein .................. 69

Little Dandy ..................... 65

Silver Queen 52B .................... $\quad 76$

$\mathrm{ThO}_{2}$ vein $\ldots \ldots \ldots \ldots \ldots \ldots \ldots \ldots \ldots, \quad 83$

Copper Queen ..................

Goldstone Mountain $\ldots \ldots \ldots \ldots \ldots \ldots \ldots \ldots, \quad 5,12$

Goss, W. D., analyst. ............... 74, 77, 80

Granite intrusive ...................... 2

Granulation $\ldots \ldots \ldots \ldots \ldots \ldots \ldots \ldots \ldots \ldots, 40,43$

Gravel .......................... 29, 30

Gunsight Formation $\ldots \ldots \ldots \ldots \ldots \ldots \ldots \ldots, 7,8,9$

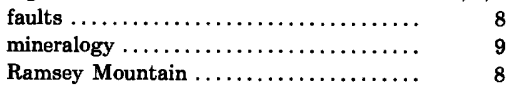

H, I

H. R. S. No. 1 .

Hall Mountain area, Idaho, correlation .......

Hanging wall, iron-oxide rich $\ldots \ldots \ldots \ldots \ldots \ldots$

Hanging-wall vein $\ldots .8,9,10,26,42,44,45,46,52,57$
$61,62,63,64,65,69,71,74,77,78,83$ Beaverhead, Montana vein

Black Bull No. 3

Cago No. 12

Contact

Dan Patch

Last Chance vein

Little Dandy ....

Lone Star No. 2 . .

Nellie B . . .

Reactor

Silver Queen 38A

$\mathrm{ThO}_{2}$ vein. .

Wonder

Wonder No. 18

Hematite claim .

Hornblende...

Horse Prairie .

Horse Prairie Creek 


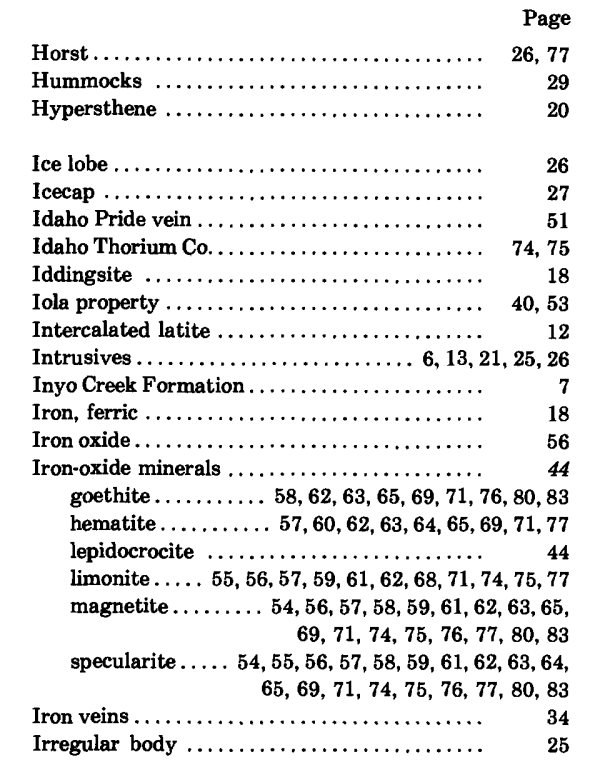

\section{J, K}

Jan Corp.

69

Jarosite $\ldots \ldots \ldots \ldots \ldots \ldots \ldots \ldots \ldots \ldots \ldots \ldots \ldots, \quad 69,76$

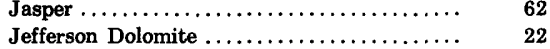

Joyce Corp. $\ldots \ldots \ldots \ldots \ldots \ldots \ldots \ldots \ldots \ldots, 74,76,77$

K. \& G. No. 1 and No. $2 \ldots \ldots \ldots \ldots \ldots \ldots \ldots$

Kadletz Volcanics ......................... 12

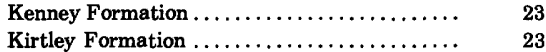

Kough Mining and Manufacturing Co. ........

Kriley Formation $. . \ldots \ldots \ldots \ldots \ldots \ldots \ldots \ldots, 14$

\section{L}

Lacustrine origin $. \ldots \ldots \ldots \ldots \ldots \ldots \ldots \ldots \ldots, 6$ Lacustrine volcanic sediments ............... 22,25

Laminations, siltite $\ldots \ldots \ldots \ldots \ldots \ldots \ldots \ldots \ldots \ldots, 6,26,28$

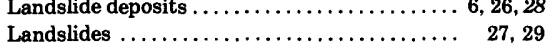

Last Chance vein ......... 5, 35, 39, 40,44, 45, 47, 49, $50,51,53,68,69$

Laths

Latite

Latite-andesite meinber.

Laughlin Peak area, New Mexico .

Lava fragments.....

Lead $\ldots \ldots \ldots \ldots \ldots \ldots \ldots \ldots \ldots 46,48,49,59,62,68,76$

Lead minerals, galena $\ldots \ldots \ldots \ldots \ldots \ldots \ldots \ldots, 46,49,62$ pyromorphite .................. 46, 49, 59 wulfenite $\ldots \ldots \ldots \ldots \ldots \ldots \ldots \ldots \ldots \ldots, 46,49,59$ Lead-silver veins ............................. 30 Leadore, Idaho . . . . . . . . . . . . . . . . 2, 5, 12, 30

Leadore Quadrangle $\ldots \ldots \ldots \ldots \ldots \ldots \ldots, 6,7,11,30$ Lemhi ............................. 30,80 Lemhi County, Idaho $\ldots \ldots \ldots \ldots \ldots \ldots \ldots \ldots, 2,5$ Lemhi Group $\ldots \ldots \ldots \ldots \ldots \ldots \ldots \ldots \ldots \ldots, 7,8,11,30$ Lemhi Pass ............. 2, 3, 5, 12, 14, 15, 16, 21, 22 $23,32,33,53,62,68,72$

Lemhi Pass fault $\ldots \ldots \ldots \ldots \ldots 8,10,11,13,19,22,31$,
$32,33,40,41,52,54,55$
Lemhi Pass Quadrangle $\ldots \ldots \ldots .5,7,11,12,22,23,48$

Lemhi Pass fault $\ldots \ldots \ldots \ldots \ldots 8,10,11,13,19,22,31$,
$32,33,40,41,52,54,55$
Lemhi Pass Quadrangle $\ldots \ldots \ldots .5,7,11,12,22,23,48$ Lemhi Pass Quadrangle $\ldots \ldots \ldots \ldots .5,7,11,12,22,23,48$
Lemhi Pass Road $\ldots \ldots \ldots \ldots \ldots \ldots \ldots \ldots \ldots .5,55$ Lemhi Pass Thorium Corp. .............. 73 Lemhi Pass thorium district ..... 2, 4, 5, 6, 7, 8, 10, 13, $14,16,22,23,24,25,27,28,30,35,40,44,45,68$ $\begin{array}{ll}\text { age } \ldots \ldots \ldots \ldots \ldots \ldots \ldots \ldots \ldots \ldots \ldots \ldots \ldots \ldots & 52 \\ \text { alkalic content } \ldots \ldots \ldots \ldots \ldots \ldots \ldots \ldots, & 53\end{array}$ derivation $\ldots \ldots \ldots \ldots \ldots \ldots \ldots \ldots \ldots \ldots, 53$ mineralogy $42,52,53$
Lemhi Pass thorium district-Continued

reserves

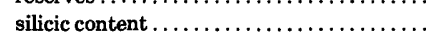

steep faults.

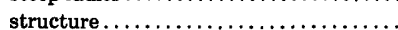

thrust faults.

tilting and folding $\ldots \ldots \ldots \ldots \ldots \ldots$

uranium content $\ldots \ldots \ldots \ldots \ldots \ldots \ldots \ldots \ldots \ldots$

Lemhi Quartzite...

Lemhi Range. . .

Lemhi River $\ldots \ldots \ldots \ldots \ldots \ldots \ldots \ldots \ldots, 4,12,27,29,51$

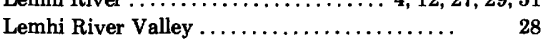

Lemhi Valley ........ 2, 4, 23, 25, 27, 28, 30, 33, 71, 80

Lenticular veins ....................... 58

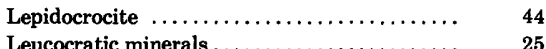

Leucocratic minerals ................... $\quad 25$

Leucoxene ...........................

Lewis and Clark trail $\ldots \ldots \ldots \ldots \ldots \ldots \ldots \ldots \ldots, \quad 2,32$
Limestone $\ldots \ldots \ldots \ldots \ldots \ldots \ldots \ldots \ldots \ldots, 1,30$

Limonite........... 9, 18,42, 43, 44, 46, 51, 52,62,

$67,68,71,74,75,76,77,78$

$\begin{array}{ll}\text { Apex } \ldots \ldots \ldots \ldots \ldots \ldots \ldots \ldots \ldots \ldots \ldots & 74 \\ \text { Beaverhead, Montana vein } \ldots \ldots \ldots \ldots \ldots & 63\end{array}$

$\begin{array}{lr}\text { Beaverhead, Montana vein } \ldots \ldots \ldots \ldots \ldots \ldots & \mathbf{6 3} \\ \text { Black Bear No. } 1 \ldots \ldots \ldots \ldots \ldots \ldots \ldots \ldots \ldots & \mathbf{5 9}, \mathbf{6 1}\end{array}$

Black Bull No. $3 \ldots \ldots \ldots \ldots \ldots \ldots \ldots \ldots, \quad 57$

Black Rock, Montana vein ............ 67,68

Blue Boar ...................... 52

Buffalo ......................... 55, 56

Cago No. $12 \ldots \ldots \ldots \ldots \ldots \ldots \ldots \ldots \ldots, 62$

Elkorn $\ldots \ldots \ldots \ldots \ldots \ldots \ldots \ldots \ldots \ldots, \quad 71$

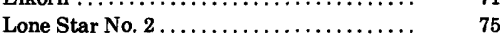

Reactor $. . \ldots \ldots \ldots \ldots \ldots \ldots \ldots \ldots \ldots, \quad 71$

Silver Queen 38A .................. $\quad 77$

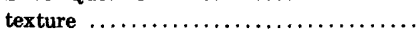

Lithic clasts.

Little Dandy mine $\ldots \ldots \ldots \ldots \ldots \ldots \ldots \ldots, \quad 65$

Little Dry Gulch $\ldots \ldots \ldots \ldots \ldots \ldots \ldots \ldots \ldots, 9,27,51$

Gunsight Formation $\ldots \ldots \ldots \ldots \ldots \ldots \ldots$

Little Eightmile Creek ................... 2,4

Little Eightmile Creek Basin $\ldots \ldots \ldots \ldots \ldots \ldots, \quad \mathbf{2 8 , 2 9}$

Locality $122 \ldots \ldots \ldots \ldots \ldots \ldots \ldots \ldots \ldots, \quad 49$

Lodgepole Limestone .......................

Lone Star No. $2 \ldots \ldots \ldots \ldots \ldots \ldots \ldots \ldots \ldots, \quad 46$

Lone Star vein ........................

Long Canyon

Long dike. .

Lost Trail Pass

Lucky Horseshoe property

$35,39,40,42$

Lucky Strike vein .................... 63

Lupine vein $\ldots \ldots \ldots \ldots \ldots \ldots \ldots \ldots \ldots \ldots \ldots \ldots \ldots \ldots \ldots \ldots \ldots \ldots, \quad 51$

$\mathbf{M}$

M. S. D. No. 1 vein $\ldots \ldots \ldots \ldots \ldots \ldots \ldots \ldots \ldots$

McDevitt Creek ....................... 5,34

McGowan Formation .................. 11

Madison Limestone . . . . . . . . . . . . . . , 11, 29, 30 $\begin{array}{ll}\text { age } \ldots \ldots \ldots \ldots \ldots \ldots \ldots \ldots \ldots \ldots \ldots \ldots & 11 \\ \text { lithology } \ldots \ldots \ldots \ldots \ldots \ldots \ldots \ldots \ldots \ldots \ldots & 11\end{array}$ lithology $\ldots \ldots \ldots \ldots \ldots \ldots \ldots \ldots \ldots \ldots, \quad 11$

Mafic minerals $\ldots \ldots \ldots \ldots \ldots \ldots \ldots \ldots \ldots, 25,26,61$

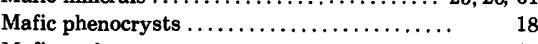

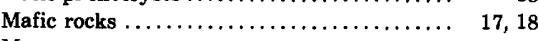

Magma

$9,10,11,18,20,26,43,53,54,55$, $56,57,58,59,61,62,63,64,65,68$, $69,71,74,75,76,77,80,83$

Apex ................................ 74

Beaverhead, Montana vein .............. 63

Black Bear No. $2 \ldots \ldots \ldots \ldots \ldots \ldots \ldots \ldots \ldots, \quad 59,61$

Black Bull No. 3 .................. 57

Black Rock, Montana vein ............. 68

Black Rock property ................ $\quad 80$

Buffalo .......................... 55, 56

Cago No. $12 \ldots \ldots \ldots \ldots \ldots \ldots \ldots \ldots \ldots$

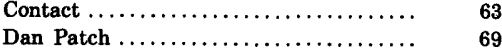

Magnetite-Continued

Deer Fraction 1A .

Elkhor

Last Chance vein

Little Dandy ...

Lone Star No. 2 .

Lucky Horseshoe .

Reactor

Silver Queen $38 \mathrm{~A} \ldots \ldots \ldots \ldots \ldots \ldots \ldots \ldots \ldots \ldots$

Silver Queen 52B

$\mathrm{ThO}_{2}$ vein

Wonder

Wonder No. 18

Page

. Manganese oxide minerals, black ...... 43, 45, 61, 68 , $69,74,76,83$

Wonder vein

45

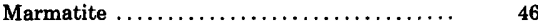

Martite ........................... 52

Massive quartz-hematite vein ............ $\quad 76$

Medicine Lodge Volcanics, correlation ........ 30

Mica ........................... 10

Microcline...... 8, 34, 40,42, 43, 49, 54, 55, 56, 61, 62 $63,65,68,69,71,74,75,76,77,80,83$

Beaverhead, Montana vein ............. 63

Black Bear No. $2 \ldots \ldots \ldots \ldots \ldots \ldots \ldots \ldots \quad 59,61$

Black Rock, Montana vein ............. 68

Black Rock property $\ldots \ldots \ldots \ldots \ldots \ldots \ldots, \quad 80$

Buffalo ......................... 55, 56

Cago No. $12 \ldots \ldots \ldots \ldots \ldots \ldots \ldots \ldots \ldots$

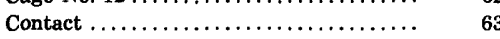

Dan Patch ...................... 69

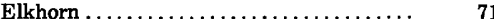

igneous rock ......................

Last Chance vein .................. 69

Little Dandy .....................

Lone Star No. $2 \ldots \ldots \ldots \ldots \ldots \ldots \ldots \ldots, \quad 75$

Lucky Horseshoe .................

pink, Apex ...................... 74

Silver Queen 38A ...............

potassium content .................. $\quad 59$

Reactor ........................... 71

Silver Queen 52B ................. 76

$\mathrm{ThO}_{2}$ vein $\ldots \ldots \ldots \ldots \ldots \ldots \ldots \ldots \ldots \ldots \ldots, 83$

twinning $\ldots \ldots \ldots \ldots \ldots \ldots \ldots \ldots \ldots, 43$

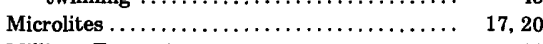

Milligen Formation .................... 11

See McGowan Formation .............

Mineral Hill area ......................

Mineral Hill mining district.............. 5

Mineralogy, Lemhi Pass thorium district.... 52, 53

Minerals, albite ........................ 18, 20 allanite $\ldots \ldots \ldots \ldots \ldots \ldots \ldots \ldots \ldots \ldots \ldots \ldots \ldots \ldots \ldots \ldots \ldots \ldots \ldots \ldots \ldots, 5,6,62$

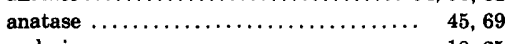
andesine $\ldots \ldots \ldots \ldots \ldots \ldots \ldots \ldots \ldots \ldots, 18,25$ andesite ........................ 12,52 apatite $\ldots \ldots \ldots \ldots, 10,11,26,43,45,53,55,61,62$, $64,68,69,71,74,76,80,83$

augite $\ldots \ldots \ldots \ldots \ldots \ldots \ldots \ldots \ldots \ldots, 16,18,26$

azurite $\ldots \ldots \ldots \ldots \ldots \ldots \ldots \ldots \ldots \ldots \ldots \ldots, 46,51,61$

barite $\ldots \ldots \ldots \ldots . \ldots \ldots, 42,43,44,49,51,52,55,57,59$, $61,62,64,68,69,71,74,75,76,80,83$

basalt .............. 12,13,16,17, 22, 26, 69

biotite $\ldots \ldots \ldots \ldots \ldots \ldots .9,10,11,15,16,18,20,21$ $22,26,28,54,69,71,74$

black manganese oxides ......... 43, 45, 61, 68 , $69,74,76,83$

bornite

brookite $\ldots \ldots \ldots \ldots \ldots \ldots \ldots \ldots \ldots \ldots \ldots \ldots \ldots \ldots \ldots \ldots \ldots, 45,68,69$ calcite $\ldots \ldots \ldots .17,26,42,43,51,52,53,55,56,57$, $59,61,68,69,74,76$

$\begin{array}{lr}\text { carbonates } \ldots \ldots \ldots \ldots \ldots \ldots \ldots \ldots \ldots \ldots & 43 \\ \text { carbonatites } \ldots \ldots \ldots \ldots \ldots \ldots \ldots \ldots \ldots & 2,53\end{array}$ $\begin{array}{lr}\text { carbonatites } \ldots \ldots \ldots \ldots \ldots \ldots \ldots \ldots \ldots \ldots & 2,53 \\ \text { chalcedony } \ldots \ldots \ldots \ldots \ldots \ldots \ldots \ldots \ldots & 17,52\end{array}$ chalcopyrite $\ldots \ldots \ldots \ldots 46,51,53,55,61,62,76,80$ chlorite $\ldots \ldots \ldots .8,10,11,18,24,26,34,52,53,61$ chrysocolla ...................... $51,61,68$ copper $\ldots \ldots \ldots 26,46,48,51,55,59,60,61,68,76$ covellite $\ldots \ldots \ldots \ldots \ldots \ldots \ldots \ldots \ldots \ldots, \quad 46,51$

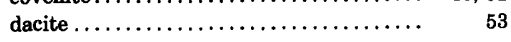


Minerals, albite-Continued epidote $8,9,10,18,21,22,24$ $30,40,43,59,75,76,83$ fluorite $\ldots \ldots \ldots \ldots \ldots \ldots \ldots .45,55,65,74,76,80$ galena $\ldots \ldots \ldots \ldots \ldots \ldots \ldots \ldots \ldots \ldots \ldots, 46,49,62$ greenish-gray quartzite ............... 8,10 goethite $\ldots \ldots \ldots \ldots \ldots \ldots \ldots .44,53,58,62,63,65$ $69,71,76,80,83$ gold $\ldots \ldots \ldots \ldots \ldots \ldots 48,49,51,55,59,62,64,74,76$ hematite ....... 8, 9, 10, 26, 42, 44, 45, 46, 52, 57 $61,62,63,64,65,69,71,74,77,78,83$ hornblende ............... 20, 21, 24, 26, 61 hypersthene ....................... 20 iddingsite $\ldots \ldots \ldots \ldots \ldots \ldots \ldots \ldots \ldots, \quad 18$ jarosite $\ldots \ldots \ldots \ldots \ldots \ldots \ldots \ldots \ldots \ldots \ldots, \quad 69,76$ jasper.............................. 62 lead $\ldots \ldots \ldots \ldots \ldots \ldots \ldots \ldots 46,48,49,59,62,68,76$ lepidocrocite $\ldots \ldots \ldots \ldots \ldots \ldots \ldots \ldots \ldots, \quad 44$ leucoxene

limonite...... 9, 18, 42, 43, 44, 46, 51, 52, 55, 62 , $67,68,71,74,75,76,77,78$ magnetite ......9, $10,11,18,20,26,43,53,54,55$ $56,57,58,59,61,62,63,64,65,68,69,71$, $74,75,76,77,80,83$ malachite $\ldots \ldots \ldots \ldots \ldots 43,46,48,51,53,61,69,80$ marmatite $\ldots \ldots \ldots \ldots \ldots \ldots \ldots \ldots \ldots, \quad 46$

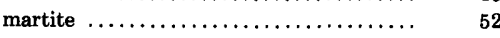
mica ........................... 10 microcline..... 8, 34, 40,42, 43, 49, 54, 55, 56, 61 , $62,63,65,68,69,71,74,75,76,77,80,83$ molybdenite................... 46, 49,51 molybdenum . $\ldots \ldots \ldots \ldots \ldots \ldots \ldots \ldots, 46,48,49,59$

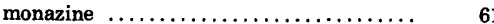
monazite $\ldots \ldots \ldots \ldots \ldots \ldots \ldots \ldots \ldots \ldots \ldots \ldots, 43,44,53,55,62,63,68$, $69,71,76,83$

montmorillonite .................... muscovite $\ldots \ldots .43,45,55,63,64,65,69,71,76,83$ olivine $\ldots \ldots \ldots \ldots \ldots \ldots \ldots \ldots \ldots \ldots \ldots, 18$
orthoclase $\ldots \ldots \ldots \ldots \ldots \ldots \ldots \ldots, 15,20,26$ pigeonite ........................ 18 plagioclase $\ldots \ldots \ldots \ldots 8,10,11,15,16,18,20,21$ $22,24,25,55,61$

porcelanite $\ldots \ldots \ldots \ldots \ldots \ldots \ldots \ldots \ldots \ldots, \quad 20$ psilomelane $\ldots \ldots \ldots \ldots \ldots \ldots \ldots \ldots \ldots, \quad 45$ pyrite $\ldots \ldots \ldots \ldots 26,43,45,51,52,55,56,57,59$, $61,62,63,64,65,69,71,80$

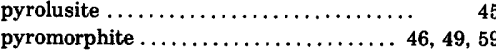
pyroxene $\ldots \ldots \ldots \ldots \ldots \ldots \ldots \ldots \ldots \ldots, \quad 18$ pyrrhotite.

quartz $\ldots \ldots \ldots, 10,11,15,20,21,22,24,26,34,40$ $42,43,46,52,54,55,56,58,59,61,62,63$ $64,68,69,74,75,76,77,78,80,83$ quartzite $\ldots \ldots \ldots 10,11,14,16,26,27,61,68,73,79$ rhyolite $\ldots \ldots \ldots \ldots \ldots \ldots \ldots \ldots \ldots, 12,14,22,52$ rutile $\ldots \ldots \ldots \ldots 43,45,52,55,56,69,61,62,63,64$. $68,69,71,74,76,77,80,83$

sanidine $\ldots \ldots \ldots \ldots \ldots \ldots \ldots \ldots 15,16,20,22,24$ sericite ........... 8, 9, 10,11, 24, 26, 30, 34, 40 serpentine ....................... 18 siderite $\ldots \ldots \ldots \ldots \ldots \ldots \ldots \ldots \ldots \ldots, 42,43,61,80$ siltite $\ldots \ldots \ldots \ldots 6,7,8,9,10,11,16,26,27,51,54$ $58,63,70,76,83$ silver $\ldots \ldots \ldots \ldots \ldots \ldots \ldots, 49,59,62,64,68,74$ specularite $\ldots \ldots \ldots 44,51,52,53,55,56,57,58,59$, $61,62,63,64,65,68,69,71,74,75,76,77,80,83$ sphalerite $\ldots \ldots \ldots \ldots \ldots \ldots \ldots \ldots \ldots \ldots, 46,61$

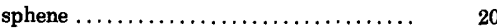

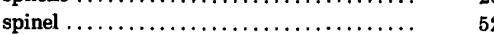
synchisite $\ldots \ldots \ldots \ldots \ldots \ldots \ldots \ldots \ldots \ldots, \quad \mathbf{7 4}$

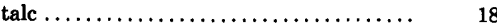
tourmaline $\ldots \ldots \ldots \ldots \ldots \ldots \ldots \ldots, 8,9,10,11,24$ thorite $\ldots \ldots \ldots \ldots 40,42,43,46,55,56,57,58,59$, $61,63,64,65,68,69,71,74,75,76,77,80,83$

tridymite $\ldots \ldots \ldots \ldots \ldots \ldots \ldots \ldots \ldots, \quad 20$ uranium $\ldots \ldots \ldots \ldots \ldots \ldots \ldots \ldots \ldots \ldots, \quad{ }^{6}$
wulfenite $\ldots \ldots \ldots \ldots \ldots \ldots \ldots \ldots \ldots \ldots, 46,49,59$ wulfenite $\ldots \ldots \ldots \ldots \ldots \ldots \ldots \ldots \ldots, 46,49,59$ zinc $\ldots \ldots \ldots \ldots \ldots \ldots \ldots, 46,48,49,89,9,10,11,20,24$
Miocene fan $\ldots \ldots \ldots \ldots \ldots \ldots \ldots \ldots \ldots \ldots, \quad$ Pag Mission Canyon Limestone, correlation ......... 11 Modoc area, Calif. .................... Molybdenite ...................... 46, 49, 51 Copper Queen mine ............... 51 Molybdenum....................46, 48, 49, 59 Molybdenum minerals, molybdenite ....... 46, 49, 51 wulfenite, yellow platy $\ldots \ldots \ldots \ldots \ldots \ldots, 46,49$ Monazine $\ldots \ldots \ldots \ldots \ldots \ldots \ldots \ldots \ldots \ldots \ldots, \quad 61$ Monazite $\ldots \ldots \ldots 43,44,53,55,62,63,68,69,71,76,83$ Montmorillonite ...................... Moraines ........................... 27

Mornell vein

Mountain glaciers .................... 27

Mountain Pass region, Calif . . . . . . . . . . . . 43

Mud flow, Holocene $\ldots \ldots \ldots \ldots \ldots \ldots \ldots \ldots, 26,29$ Muscovite $\ldots \ldots \ldots \ldots 43,45,55,63,64,65,69,71,76,83$ Beaverhead, Montana vein ............ 63

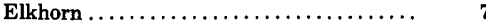
Last Chance vein $\ldots \ldots \ldots \ldots \ldots \ldots \ldots \ldots$ Little Dandy ...

Lucky Horseshoe ...

Silver Queen 52B

$\mathrm{ThO}_{2}$ vein ....

Wonder No. $18 \ldots \ldots \ldots \ldots \ldots \ldots \ldots . . . \ldots$

\section{$\mathrm{N}, \mathrm{O}$}

Nellie B $\ldots \ldots \ldots \ldots \ldots \ldots \ldots \ldots \ldots \ldots \ldots \quad 77,78$ Neodymium $\ldots \ldots \ldots \ldots \ldots \ldots \ldots \ldots \ldots \ldots, \quad 69$ Nielsen Ranch $. \ldots \ldots \ldots \ldots \ldots \ldots \ldots \ldots \ldots, \quad 5$ No Pay vein ........................ 51 Non-thorium bearing copper veins $\ldots \ldots \ldots \ldots, \quad 46,51$ North Fork, Idaho ................... 2,14 North Fork Quadrangle ................. 23 North Frying Pan Creek .......... 2, 3, 27, 34, 62, 63, $65,67,68,69$

Nuclear Fuels and Golden Pleasures Mining Co. $\quad 59$ Nuclear Fuels and Rare Metals Corp...... 57, 58, 59, $60,62,65,74,75,77$

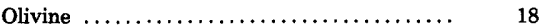

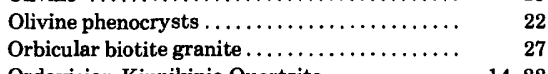
Ordovician Kinnikinic Quartzite ........... 14, 22 Orthoclase ...................... 10, 15, 20, 26 Oxides $\ldots \ldots \ldots \ldots \ldots \ldots \ldots \ldots \ldots, 18,34,40,42,43,45,46$

Pattee Creek ....... 2, 4, 12, 14, 16, 23, 24, 26, 28, 29, $32,33,34,40,50,74,75,77$

Pattee Creek area ....................... 30

Pattee Creek fault $\ldots \ldots \ldots \ldots \ldots \ldots \ldots \ldots \ldots \ldots, 13,33,52$ Patterson Quadrangle.

Pebbles

Peterson Creek ..... 2, 4, 7, 10,11,13,25,28, 29,34,43 Left Fork $\ldots \ldots \ldots \ldots \ldots \ldots \ldots \ldots \ldots, 8,30$ Right Fork

Peterson Creek thrust fault $\ldots \ldots \ldots \ldots \ldots 2,6,7,8,9,10$,

$11,13,30,33,34$
$\ldots \ldots \ldots$

Big Creek Formation

Gunsight Formation

Phenocrysts

Phyllite $\ldots \ldots \ldots \ldots \ldots \ldots \ldots \ldots \ldots \ldots \ldots, \quad 7,11$

Pigeonite

Pine veins

18
49

Pitkin, Inc. Lucius, analyst . . . . $55,59,61,62,63$, $65,68,71,76,77,78,80,83$

Plagioclase $\ldots \ldots \ldots \ldots \ldots \ldots \ldots 8,10,11,15,16,18,20$, $21,22,24,25,55,61$

microlites phenocrysts $\ldots \ldots \ldots \ldots \ldots \ldots \ldots \ldots \ldots \ldots, \quad 22$ porphyries $\ldots \ldots \ldots \ldots \ldots \ldots \ldots \ldots \ldots \ldots, \quad 16$ Poison Creek . . . . . . . . . . . 74, $77 \ldots \ldots \ldots \ldots, 12,73$

Poison Gulch Spring ................... $\begin{array}{ll}\text { Porcelanite } \ldots \ldots \ldots \ldots \ldots \ldots \ldots \ldots \ldots \ldots \ldots \ldots & 20 \\ \text { Post-Challis Volcanics } \ldots \ldots \ldots \ldots \ldots \ldots \ldots \ldots & 52\end{array}$ Post-Challis Volcanics $\ldots \ldots \ldots \ldots \ldots \ldots \ldots \ldots$,
Postdiorite $\ldots \ldots \ldots \ldots \ldots \ldots \ldots \ldots \ldots \ldots \ldots$ Potassium $\ldots \ldots \ldots \ldots \ldots \ldots \ldots \ldots \ldots, 16,22,48,49$
Powderhorn Mountain district, Colo....... $\quad \begin{array}{r}\text { Page } \\ 43,45\end{array}$ Precambrian Y quartzite ........ 14, 18, 20, 24, 26, 27, $29,30,33,34,48,50,51,52$ $55,57,58,59,60,62,63,68$ $69,70,71,73,74,77,79$ Precambrian $Y$ sedimentary rocks $\ldots \ldots .4,6,10,13,16$, $22,26,33,46$ lithology

Psilomelane

Pumice Pyrite $\ldots \ldots \ldots \ldots \ldots \ldots 26,43,45,51,52,55,56,57,59$
$61,62,63,64,65,69,71,80$

Black Bear No. 2

Black Bull No. $3 \ldots \ldots \ldots \ldots \ldots \ldots \ldots \ldots$

Black Rock property

Buffalo

Cago No. 12 .

Copper Queen ...

Deer Fraction 1A

Last Chance vein

Little Dandy

pseudomorphous replacement . ..... 59,62,69,76

pyritohedrons

Reactor

Silver Queen 52B

Wonder

Wonder No. 18

\section{Pyroclastics ..}

Pyrolusite ....

Pyromorphite

Pyroxene

Pyrrhotite

Quartz .........10, 11, 15, 20, 21, 22, 24, 26, 34, 40, $42,43,46,52,54,55,56,58,59,61,62,63$ $64,68,69,74,75,76,77,78,80,83$

Apex

Beaverhead, Montana vein

Black Rock, Montana vein

Black Rock property

Blue Boar

Buffalo

Cago No. 12

Contact ......

Deer Fraction 1A

Elkhorn .

Last Chance vein

limonite-stained, Nellie B

location 194

Lone Star No. 2

Lucky Horseshoe

Silver Queen 38A

Silver Queen 52B

white. . .

Wonder

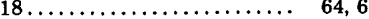

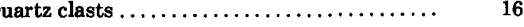

Quartz diorite $\ldots \ldots \ldots \ldots \ldots \ldots \ldots \ldots \ldots \ldots, 27,30$

Quartz latite ...................... 19, 20, 21, 22

flow $\ldots \ldots \ldots \ldots \ldots \ldots \ldots \ldots \ldots \ldots, 13,17,21$

Quartz monzonite ..................... 27

Quartz-hematite vein, Silver Queen 52B ...... 74

Quartz-rich footwall .................. 74

Quartzite......... 10, 11, 14, 16, 26, 27, 61, 68, 73, 79

breccia ........................... 31 clasts ...................... 21, 26, 27, 28 dark-gray ......................... 15 feldspathic $\ldots \ldots \ldots \ldots \ldots \ldots, 6,7,8,9,10,28,30,76$

float

fragments $\ldots \ldots \ldots \ldots \ldots \ldots \ldots \ldots \ldots$

greenish-gray

horst

massive . Black Bear No. 2

$6.6,7,8,10,16,55,57,58,59$,
$60,62,63,68,69,70,74,77,79$ 


\begin{tabular}{|c|c|}
\hline & Page \\
\hline \multicolumn{2}{|l|}{ Thorium minerals-Continued } \\
\hline silicic igneous rocks & 45 \\
\hline synchisite .......... & 45,74 \\
\hline $\begin{array}{r}\text { thorite } \ldots \ldots \ldots .55,57,58,59,61,62,63,65 \\
74,75,77\end{array}$ & $\begin{array}{l}69,71 \\
80,83\end{array}$ \\
\hline $\begin{array}{l}\text { xenotime } \ldots \ldots \ldots \ldots \ldots \ldots \ldots \ldots \ldots \ldots \ldots \\
\text { yttrium. See doverite. }\end{array}$ & 45,83 \\
\hline \multicolumn{2}{|c|}{$\begin{array}{r}\text { Thorium veins } \ldots \ldots \ldots 2,5,6,25,26,30,34,40,45,46 \\
48,49,50,53,55,60,61,64\end{array}$} \\
\hline reserves $\ldots \ldots \ldots \ldots \ldots \ldots \ldots \ldots \ldots \ldots$ & $\mathbf{5 0}$ \\
\hline Thrust faults ........ & 30 \\
\hline Topographic lows $\ldots \ldots \ldots \ldots \ldots \ldots \ldots \ldots$ & 6,26 \\
\hline Tourmaline $\ldots \ldots \ldots \ldots \ldots \ldots \ldots \ldots \ldots, 8,9,10$ & $, 11,24$ \\
\hline Trachybasalt ... & 18,19 \\
\hline Trail Creek $\ldots \ldots \ldots \ldots \ldots \ldots \ldots \ldots \ldots 2,4,16,19$ & 22,29 \\
\hline Trapper Creek.$\ldots \ldots \ldots \ldots \ldots \ldots \ldots \ldots \ldots 13$ & $3,16,27$ \\
\hline Trapper No. $1 \ldots \ldots \ldots \ldots \ldots \ldots \ldots \ldots \ldots, 42$ & 62,63 \\
\hline Tridymite $(\ldots, \ldots, \ldots, \ldots, \ldots, \ldots, \ldots, \ldots$ & 20 \\
\hline Tuff $\ldots \ldots \ldots \ldots \ldots \ldots \ldots, 15,20,23,24,26,27$ & $, 52,53$ \\
\hline interbedded & 12 \\
\hline $\operatorname{matrix} \ldots \ldots \ldots \ldots$ & 14,20 \\
\hline Tuffaceous sedimentary rocks, age ......... & 23,24 \\
\hline \multicolumn{2}{|l|}{$\mathrm{U}, \mathrm{V}$} \\
\hline Unio & 68 \\
\hline Uranium & 6 \\
\hline econo & 46 \\
\hline relation & 52,53 \\
\hline Vegetation $\ldots \ldots \ldots \ldots \ldots \ldots \ldots \ldots \ldots \ldots$ & 4 \\
\hline Veins $\ldots \ldots \ldots \ldots \ldots \ldots \ldots \ldots \ldots \ldots \ldots \ldots$ & 34,51 \\
\hline Apex $\ldots \ldots \ldots \ldots \ldots \ldots \ldots \ldots \ldots \ldots$ & 71 \\
\hline Atomic Blast $\ldots \ldots \ldots \ldots \ldots \ldots \ldots \ldots \ldots$ & 45 \\
\hline Barbara $\ldots \ldots \ldots \ldots \ldots \ldots \ldots \ldots, 46,48$ & 49,59 \\
\hline barren quartz $\ldots \ldots \ldots \ldots \ldots \ldots \ldots \ldots, 34,47$ & 51,64 \\
\hline Beaverhead $\ldots \ldots \ldots \ldots \ldots \ldots \ldots \ldots, 42$ & 50,63 \\
\hline No. $2 \ldots \ldots \ldots \ldots \ldots \ldots \ldots 45$ & $, 46,49$ \\
\hline$\ldots \ldots \ldots \ldots \ldots \ldots \ldots \ldots \ldots, 40$ & 50,57 \\
\hline $\mathrm{k}(\mathrm{Idaho}) \ldots \ldots \ldots \ldots \ldots \ldots \ldots$ & 79,80 \\
\hline [ontana) ................. & 65 \\
\hline Blue Boar $\ldots \ldots \ldots \ldots \ldots \ldots \ldots \ldots \ldots$ & 51,52 \\
\hline Blue Ridge $\ldots \ldots \ldots \ldots \ldots \ldots \ldots \ldots \ldots$ & 52 \\
\hline (....................... & 51 \\
\hline ............ & 40 \\
\hline Brown Bear $\ldots \ldots \ldots \ldots \ldots \ldots \ldots \ldots \ldots$ & 53 \\
\hline Brown Bear No. $2 \ldots$ & 25 \\
\hline (............ & 59 \\
\hline Buffalo & 55,56 \\
\hline Moo & 42,67 \\
\hline Cago No. 10 & 35 \\
\hline
\end{tabular}

Veins-Continued

\begin{tabular}{|c|c|}
\hline Cago No. 12 . & $\begin{array}{r}62 \\
40 \quad 49\end{array}$ \\
\hline Contact ......... & $\begin{array}{r}40,49 \\
62\end{array}$ \\
\hline copper . & 34,51 \\
\hline copper-bearing quartz $\ldots \ldots \ldots \ldots \ldots \ldots \ldots$ & 26 \\
\hline ................. & 51 \\
\hline \multicolumn{2}{|c|}{ Daisy Nielsen $\ldots \ldots \ldots \ldots \ldots \ldots \ldots \ldots, 5,46,49,59$} \\
\hline Dan Patch $\ldots \ldots \ldots \ldots \ldots \ldots \ldots \ldots \ldots$ & 69 \\
\hline Deer Fraction $1 \mathrm{~A} \ldots \ldots \ldots \ldots \ldots \ldots \ldots$ & 39,45 \\
\hline Elkhorn $\ldots \ldots \ldots \ldots \ldots \ldots \ldots \ldots \ldots \ldots \ldots$ & 71 \\
\hline \multicolumn{2}{|c|}{$\begin{array}{l}\text { Frying } \operatorname{Pan} \ldots \ldots \ldots \ldots \ldots \ldots \ldots \ldots \ldots \ldots \ldots \ldots \ldots \ldots \ldots \ldots \ldots \ldots \ldots \ldots, \mathbf{3 9}, \mathbf{4 2}, \mathbf{4 8} \\
\text { G \& G } \ldots \ldots \ldots \ldots \ldots, \mathbf{4 2}, 50\end{array}$} \\
\hline granulation $\ldots \ldots \ldots \ldots \ldots \ldots \ldots \ldots \ldots$ & 40 \\
\hline 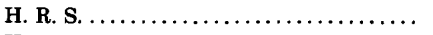 & 42 \\
\hline Hematite $\ldots \ldots \ldots \ldots \ldots \ldots \ldots \ldots \ldots \ldots$ & 52 \\
\hline Idaho Pride $\ldots \ldots \ldots \ldots \ldots \ldots \ldots \ldots \ldots$ & 51 \\
\hline Iola property $\ldots \ldots \ldots \ldots \ldots \ldots \ldots \ldots \ldots$ & 40,53 \\
\hline 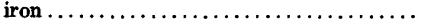 & 34 \\
\hline iron oxides $\ldots \ldots \ldots \ldots \ldots \ldots \ldots \ldots \ldots \ldots$ & 40 \\
\hline Last Chance...$\ldots \ldots \ldots \ldots \ldots \ldots \ldots \ldots$ & 68 \\
\hline lead-silver $\ldots \ldots \ldots \ldots \ldots \ldots \ldots \ldots \ldots \ldots$ & 30 \\
\hline Little Dandy ...................... & 65 \\
\hline locality $122 \ldots \ldots \ldots \ldots \ldots \ldots \ldots \ldots \ldots$ & 49 \\
\hline Lone Star ....................... & 74 \\
\hline Lone Star No. $2 \ldots \ldots \ldots \ldots \ldots \ldots \ldots \ldots$ & 46 \\
\hline Lorado ............................ & 5 \\
\hline$\ldots \ldots, \cdots, \cdots, \cdots, \cdots, \cdots$, & 49 \\
\hline Lucky Horseshoe $\ldots, \ldots, \ldots, \ldots, \ldots, \ldots$ & 54,55 \\
\hline Lucky Strike $[\ldots, \ldots, \ldots, \ldots, \ldots, \ldots$, & 63 \\
\hline Lupine $\ldots \ldots \ldots \ldots \ldots \ldots \ldots \ldots \ldots \ldots \ldots$ & 51 \\
\hline M. S. D. No. $1 \ldots \ldots \ldots \ldots \ldots \ldots \ldots \ldots \ldots \ldots$ & 47 \\
\hline Mornell $\ldots \ldots \ldots \ldots \ldots \ldots \ldots \ldots \ldots \ldots \ldots$ & 40 \\
\hline Nellie B $\ldots \ldots \ldots \ldots \ldots \ldots \ldots \ldots \ldots \ldots$ & 77 \\
\hline No Pay $\ldots \ldots \ldots \ldots \ldots \ldots \ldots \ldots \ldots \ldots \ldots$ & 51 \\
\hline Pine Nos. $1 \& 2 \ldots \ldots \ldots \ldots \ldots \ldots \ldots$ & 49 \\
\hline Radio $\ldots \ldots \ldots \ldots \ldots \ldots \ldots \ldots \ldots \ldots \ldots \ldots \ldots$ & 53 \\
\hline Rangand $\ldots \ldots \ldots \ldots \ldots \ldots \ldots \ldots \ldots \ldots$ & 63 \\
\hline Reactor $\ldots \ldots \ldots \ldots \ldots \ldots \ldots \ldots \ldots \ldots, \ldots$ & 70 \\
\hline Rufus $\ldots \ldots \ldots \ldots \ldots \ldots \ldots \ldots \ldots \ldots \ldots \ldots \ldots$ & 51 \\
\hline 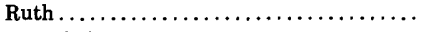 & 5 \\
\hline Scott lode $\ldots \ldots \ldots \ldots \ldots \ldots \ldots \ldots \ldots \ldots$ & 79 \\
\hline Shady Tree $\ldots \ldots \ldots \ldots \ldots \ldots \ldots \ldots \ldots$ & 53 \\
\hline Shear Zone $\ldots \ldots \ldots \ldots \ldots \ldots \ldots \ldots, 34,40,44$ & 50,62 \\
\hline Silver Queen 38A $\ldots \ldots \ldots \ldots \ldots \ldots \ldots$ & 77 \\
\hline Silver Queen 52B ................... & 75,76 \\
\hline Silvertip $\ldots \ldots \ldots \ldots \ldots \ldots \ldots \ldots \ldots \ldots$ & 49 \\
\hline strike $\ldots \ldots \ldots \ldots \ldots \ldots \ldots \ldots \ldots \ldots \ldots$ & 40 \\
\hline 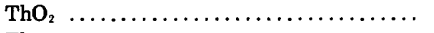 & 80 \\
\hline 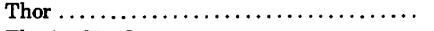 & 42 \\
\hline Thor & 47 \\
\hline
\end{tabular}

Veins-Continued

thorium ........... 34, 35, 39, 40, 50, 53, 61, 64 Three-and-One $\ldots \ldots \ldots \ldots \ldots \ldots \ldots \ldots \ldots, \quad 53$ Trapper ....................... 42, 62 Uranium Queen $. . . \ldots \ldots \ldots \ldots \ldots \ldots \ldots, \quad 53$ Viola $\ldots \ldots \ldots \ldots \ldots \ldots \ldots \ldots \ldots \ldots, \quad 39,47$

Wonder $\ldots \ldots \ldots \ldots \ldots \ldots \ldots \ldots \ldots \ldots, 64$ Viola $. . \ldots \ldots \ldots \ldots \ldots \ldots \ldots \ldots \ldots \ldots \ldots, \quad 39,47$ Vitric clasts $\ldots \ldots \ldots \ldots \ldots \ldots \ldots \ldots \ldots \ldots \ldots \ldots \ldots \ldots \ldots \ldots \ldots \ldots \ldots \ldots \ldots \ldots \ldots \ldots \ldots \ldots, 18,20$ Vitric-crystal tuff $\ldots \ldots \ldots \ldots \ldots \ldots \ldots \ldots \ldots, \quad 15$ Vitric fragments. Vitric tuff of Curtis Ranch .......... 13, 16,18, 19, 20 , $21,22,23$ Volcanic ash $\ldots \ldots \ldots \ldots \ldots \ldots \ldots \ldots \ldots \ldots, 15,23$ Volcanic rocks $\ldots \ldots \ldots \ldots \ldots \ldots \ldots \ldots \ldots \ldots \ldots, 6,26,52$

Volcanic sandstone $\ldots \ldots \ldots \ldots \ldots \ldots \ldots \ldots$

Volcanism

W

Walberg, J. S., analyst $55,69,71$

Wallace Formation

Weathering

Weis, P. L., Armstrong, F. C., and Rosenblum,

Welded tuff ... Samuel, quote.

sanidine quartz.......

$\ldots \ldots \ldots \ldots 13,22,30$

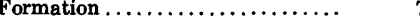

Wheat Spring $\ldots \ldots \ldots \ldots \ldots \ldots \ldots \ldots \ldots, \quad 31,77$

White Creek $\ldots \ldots \ldots \ldots \ldots \ldots \ldots \ldots \ldots \ldots, 15,21,28,29$

Wonder veins $\ldots \ldots \ldots \ldots \ldots 25,26,41,42,43,45,46,48$,

$49,51,59,64$

Wulfenite $\ldots \ldots \ldots \ldots \ldots \ldots \ldots \ldots \ldots \ldots \ldots \ldots, 46,49,59$

$\mathbf{Y}, \mathbf{Z}$

Yankee Fork Rhyolite Member............ 12 Yankee Fork Rhyohte Member $\ldots \ldots \ldots \ldots \ldots, 12$, $24,28,29,31,34,40,71$

South Fork $\ldots \ldots \ldots \ldots \ldots \ldots \ldots \ldots \ldots .2,29,39$

Yearian Creek area $\ldots \ldots \ldots \ldots \ldots \ldots$

Yearian Creek Basin $\ldots \ldots \ldots \ldots \ldots \ldots \ldots \ldots, \quad 26,33$

Yearian Creek fault ...................... 31,33

Yearian Creek graben $\ldots \ldots \ldots \ldots \ldots, 6,8,30,31,33,40,83$

Yearian Creek Valley . . . . . . . . . . . . . . . . . . , 22

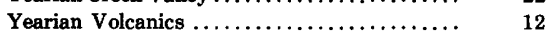

Yellowjacket Formation . . . . . . . . $\ldots \ldots \ldots \ldots, \quad 7,8$

Yellowjacket, Idaho ..................

Zinc $\ldots \ldots \ldots \ldots \ldots \ldots \ldots \ldots 46,48,49,59,60,62,68,76$

Zinc analysis $\ldots \ldots \ldots \ldots \ldots \ldots \ldots \ldots \ldots \ldots \ldots, \quad 62$ 